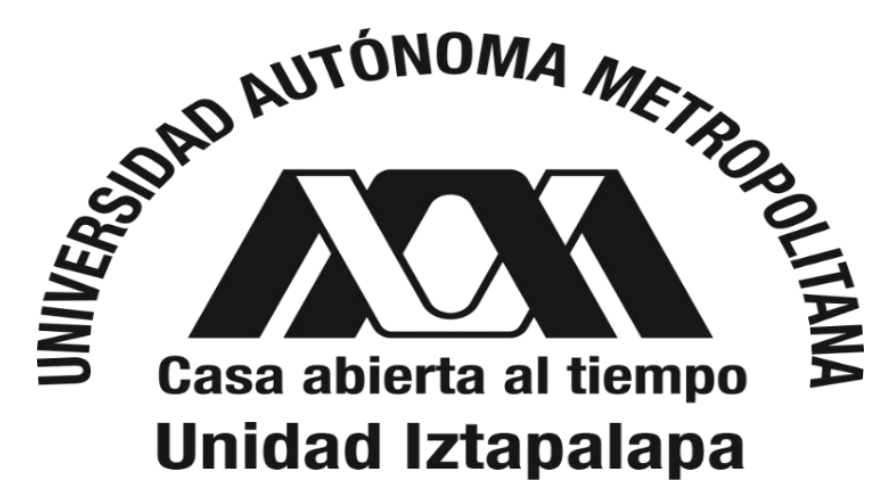

DIVISIÓN DE CIENCIAS SOCIALES Y HUMANIDADES

\title{
AGUDEZA E INGENIO EN CINCO POÉTICAS ESPAÑOLAS DE LA SEGUNDA MITAD DEL SIGLO XVI Y PRINCIPIOS DEL XVII
}

TESIS QUE PRESENTA LA

LiC. SHARON SUÁREZ LARIOS,

MATRÍ́CULA 2183800742

PARA OBTENER EL GRADO DE MAESTRA EN HUMANIDADES (LITERATURA)

DIRECTOR DE TESIS

qmadu.

Dr. GuStavo Illades Aguiar

JURADO:

Dr. MARX ARriagA NAVARRO

DRA. LILLIAN VON DER WALDE MOHENO

IZTAPALAPA, CIUDAD DE MÉXICO

NOVIEMBRE, 2020 


\section{AGRADECIMIENTOS}

Variando el conocido refrán: una gota sola no hace una lluvia. Justo así somos los seres humanos, gotas aisladas que únicamente en conjunto pueden convertirse en una llovizna ligera, en lluvia que empapa, en una tormenta que arrasa con todo lo que había y deja a su paso tierra fértil. Y este trabajo es una modesta prueba. No solo porque lluvias y tormentas previas habían dejado un campo propicio para su cultivo, sino por todas aquellas personas que como preciosas gotas me acompañaron y cuyo agudo e ingenioso diálogo permitieron un diluvio de ideas que apenas las páginas pueden contener.

Enumerar las gotas incluso de la llovizna más sutil es una tarea imposible y es una realidad que me pesa porque temo no poder mencionar a todos los que hicieron posible estas páginas, desde el CM de la Biblioteca Nacional de España hasta el individuo anónimo que por una razón desconocida decidió vender un libro que necesitaba y no encontraba en ningún lado. Sin embargo, no deseo dejar de mencionar ahora a aquellos cuya ayuda ya significaba por sí misma una tempestad. Me refiero en primera instancia a mi asesor, el Dr. Gustavo Illades Aguiar, que leyó con paciencia mis trasnochadas redacciones y me ayudó a mejorarlas, mientras anotaba con agudeza incomparable observaciones que siempre enriquecieron el trabajo.

Asimismo, agradezco a cada uno de mis profesores del posgrado, porque sus enseñanzas me hicieron mejorar y perfeccionar mis habilidades como investigadora. No pueden faltar por supuesto mis lectores, la Dra. Lillian von der Walde y el Dr. Marx Arriaga, que hicieron un espacio en su apretada agenda para leer mi trabajo. Y esta primera enumeración no podría estar completa sin mencionar a todos los integrantes de la coordinación de línea, que hicieron lo que estaba en sus manos para apoyarme.

Una enumeración de gotas distintas, pero no menos importantes, empieza con mis compañeros de generación, porque más que colegas nos convertimos en amigos que podían intercambiar lo mismo reflexiones que bromas, ambas producto de su ingenio vivo e inquieto. Continuo con mi familia, ese "chipi chipi” al que agradezco que haya tolerado este proceso que no siempre fue fácil. También, a todos mis amigos, colegas del Seminario de Estudios Literarios del Siglo de Oro y personas que indirectamente me apoyaron, como gotas transversales en días despejados, les doy las gracias. En este punto, se nota ya que dejo muchos nombres fuera, pero la tierra fértil requiere tanto de lluvia como de sol y por ello Pedro no puede faltar.

Finalmente, hay lluvias diferentes que permiten la producción y el intercambio del saber. Mi profundo agradecimiento también a la Universidad Autónoma Metropolitana-Iztapalapa, que me abrió sus puertas y me permitió conocer a personas maravillosas, y a CONACyT, que apoyó económicamente esta investigación. Espero que todos los que depositaron su confianza en mí puedan ver en estas páginas una parte de todo su invaluable apoyo. Hasta la próxima lluvia. 


\section{ÍNDICE}

ADVERTENCIA

Alonso LóPEZ Pinciano: Philosophia ANTIGVA POETICA (1596) 2

Luis Alfonso de CARVAllo: CISNE DE APOLO (1602) 4

FRANCISCO CASCALES: TABLAS POETICAS (1617) 4

LUIS CARRILLO Y SOTOMAYOR: "LIBRO DE LA ERVDICION POETICA" (1611) 5

JUAN DE JÁUREGUI Y AGUILAR: DISCVRSO POETICO (1624) 7

$\begin{array}{lr}\text { INTRODUCCIÓN } & 9\end{array}$

AGUDEZA E INGENIO EN LOS DICCIONARIOS DE LA ÉPOCA

AGUDEZA E INGENIO PARA EL MUNDO CLÁSICO: ARISTÓTELES Y HORACIO 14

$\begin{array}{ll}\text { La agudeza } & 14\end{array}$

El ingenio $\quad 16$

INGENIO EN LA TEORÍA DE JUAN HUARTE DE SAN JUAN 18

CAPÍTULO I: POÉTICAS DE LA SEGUNDA MITAD DEL SIGLO XVI Y PRINCIPIOS DEL XVII

LA CRÍTICA EN TORNO A LAS POÉTICAS ESPAÑOLAS DE FINALES DEL SIGLO XVI Y PRINCIPIOS DEL XVII: NOTAS SOBRE UN PREJUICIO

El carácter tardío de las primeras poéticas españolas 26

El plagio de las primeras poéticas españolas 29

Servilismo de las poéticas ante la preceptiva italiana 32

CONSIDERACIONES A PROPÓSITO DEL AMBIENTE CULTURAL Y LOS PÚBLICOS EN LOS
SIGLOS XVI Y XVII

Humanismo español: la vulgarización de los clásicos y modernos 34

Los studia humanitatis y la academia $\quad 37$

El ideal del cortesano y su necesidad de poéticas 39

El gran público oidor: el vulgo y sus instructores 41

POÉTICAS DIALÓGICAS Y DISCURSIVAS: CARACTERÍSTICAS VINCULANTES DE CINCO POÉTICAS DE LA SEGUNDA MITAD DEL SIGLO XVI Y PRINCIPIOS DEL XVII 43

Poéticas dialógicas $\quad 45$

Poéticas discursivas $\quad 49$

CAPÍTULO II: AGUDEZA EN CINCO POÉTICAS ESPAÑOLAS DE LA SEGUNDA MITAD DEL SIGLO XVI Y PRINCIPIOS DEL XVII

POÉTICAS DIALÓGICAS

Alonso López Pinciano, Philosophia antigva poetica (1596) 53

Luis Alfonso de Carvallo, Cisne de Apolo (1602) 64

Francisco Cascales, Tablas poeticas (1617) 76

POÉTICAS DISCURSIVAS $\quad 87$

Luis Carrillo y Sotomayor, "Libro de la ervdicion poetica" (1611) 87

Juan de Jáuregui y Aguilar, Discvrso poetico (1624) 102

CAPÍTULO III: INGENIO EN CINCO POÉTICAS ESPAÑOLAS DE LA SEGUNDA MITAD DEL SIGLO XVI Y PRINCIPIOS DEL XVII 
POÉTICAS DIALÓGICAS 109

Alonso López Pinciano, Philosophia antigva poetica (1596) 109

Luis Alfonso de Carvallo, Cisne de Apolo (1602) 125

$\begin{array}{ll}\text { Francisco Cascales, Tablas poeticas (1617) } & 148\end{array}$

POÉTICAS DISCURSIVAS $\quad 158$

Luis Carrillo y Sotomayor, "Libro de la ervdicion poetica" (1611) 158

Juan de Jáuregui y Aguilar, Discvrso poetico (1624) 173

$\begin{array}{ll}\text { CONCLUSIONES } & 199\end{array}$

$\begin{array}{ll}\text { BIBLIOGRAFÍA } & 215\end{array}$ 


\section{ADVERTENCIA}

A mediados del siglo XX, Margarete Newels señalaba las dificultades no solo de encontrar bibliografía especializada sobre las poéticas de los Siglos de Oro, sino también las poéticas mismas. Las carencias intentaron ser subsanadas en su momento con los esfuerzos de recuperación realizados por el Consejo Superior de Investigaciones Científicas, a través de la Biblioteca de Antiguos Libros Hispánicos ${ }^{1}$. Más de medio siglo ha pasado desde tales afirmaciones y el estudioso de este corpŭs cuenta apenas con algunas antologías. Un par de ellas fueron hechas por Alberto Porqueras Mayo La teoría poética en el Renacimiento y Manierismo españoles (Puvill, 1986) y La teoría poética en el Manierismo y Barroco españoles (Puvill, 1989)-, otra fue realizada en colaboración con Federico Sánchez Escribano -Preceptiva dramática española: del Renacimiento y Barroco (Gredos, 1972)-, y, más recientemente, se encuentra la de José María Reyes Cano - La literatura española a través de sus poéticas, retóricas, manifiestos y textos paradigmáticos: Edad Media y Siglo de Oro (Cátedra, 2010). Por lo demás, aún se puede afirmar para la mayoría de las poéticas lo que François Lopez sugirió en 2005 sobre la Philosophia antigva poetica:

Debería publicarse la Philosophía antigua poética de Alonso López Pinciano en una colección de clásicos hispanos, con abundantes anotaciones y buenos índices. Que el texto, incluso en su más reciente edición, necesita todavía de algunas enmiendas es indiscutible, y también lo es que el lector poco versado en humanidades mal puede captar el interés, la originalidad y hasta la significación literal de no pocos trozos de la obra si no se le ayuda aclarando las referencias que en ella abundan. ${ }^{2}$

Efectivamente, de las cinco poéticas revisadas para la presente investigación, el caso más paradigmático y problemático en cuanto a edición lo representa la Philosophia de Pinciano, que aún hoy carece de un aparato crítico que ayude a desentrañar la silva de hipotextos que corren sus líneas. Sin embargo, aunque es innegable la necesidad de un texto que se acerque tanto a jóvenes hispanistas como a los recién iniciados en el estudio de los Siglos de Oro, me parece que el investigador debe reconsiderar el uso de aquellas ediciones que -en palabras de Lopez y de una gran parte de la filología contemporánea- enmiendan la editio princeps porque así lo necesita. Esta consiste básicamente en la separación en párrafos, puntuación, normalización y actualización gráfica y ortográfica, lo que aleja de una manera casi imperceptible pero cierta la voluntad del autor de las interpretaciones del más agudo investigador.

Por supuesto, entiendo que las enmiendas hacen también referencia a esas erratas de cajistas, tipógrafos e impresores, que deben de ser identificadas y señaladas, mas no modificadas directamente

\footnotetext{
${ }^{1}$ Vid. Los géneros dramáticos en las poéticas del Siglo de Oro. Investigación preliminar al estudio de la teoría dramática en el Siglo de Oro, pp. 11-13, n. 3.

2 "Sobre la moderna filosofía poética de Alonso López Pinciano", en Christophe Couderc y Benoit, «Por discreto y por amigo». Mélanges offerts à Jean Canavaggio, p. 579.
} 
en el texto, ya que, aún y cuando sean evidentes, ante la inexistencia de un manuscrito autógrafo o idiográfo -como es precisamente el caso de casi todas las poéticas estudiadas-, ¿cómo poder garantizar que el error es del cajista y no del autor? Puede ser que una edición que contemple esto, más un exhaustivo aparato crítico sean poco prácticos e incluso de lectura agotadora; sin embargo, es labor del investigador acercarse al texto y no viceversa. Por tal motivo, ante la inexistencia de una edición paleográfica anotada, los resultados de esta investigación están basados en las cinco editiones principes digitalizadas por diferentes bibliotecas europeas. No dejé de consultar, empero, el valioso trabajo de rastreo de fuentes de editores como Antonio García Berrio, Alberto Porqueras Mayo y Mercedes Blanco, entre otros.

Por otra parte, aclaro desde ahora que todas las citas de las poéticas que enunciaré a continuación son transcripciones casi paleográficas. Únicamente desligo las abreviaturas colocándolas entre paréntesis- y cambio la ese larga, "P”, por una ese breve, “s”, en cursiva. Además, aplico el mismo criterio para cualquier texto que cite y que provenga también de una editio princeps o de impresiones de los siglos XVI, XVII o XVIII.

\section{Alonso López Pinciano: Philosophia ANTIGVA POETICA (1596) ${ }^{3}$}

Tanto la Universidad Complutense de Madrid (signatura BH MED 266), como la Bayerische SttatsBiliothek digital (signatura 4 L.eleg.g. 301) ofrecen digitalizaciones de testimonios que por la humedad o encuadernación dificultan materialmente la lectura. Por tal motivo, usé la nueva versión digitalizada por la Biblioteca Digital Hispánica, que recientemente -en abril 2019- cargó a su catálogo, sustituyendo con imágenes a color y de mayor calidad la anterior a la que faltaban los folios 106 y 107. Tanto la antigua como la nueva digitalización conservaron el testimonio con signatura U|3831, al cual la BDH agrega las siguientes notas:

\footnotetext{
${ }^{3}$ No deja de ser peculiar una hipótesis reciente de Francisco Calero que le quita la paternidad de la Philosophia a López Pinciano y se la da a Juan Luis Vives, con extrapolaciones hechas por Fadrique Furió Ceriol, valenciano y consejero de Felipe II que inspiró el personaje de Fadrique en los diálogos de la poética ("La autoría de la Philosophía antigua poética", pp. 305-386), como ha demostrado Ricardo Verdú con ayuda del testimonio de Gregorio Mayans (vid. "Introducción" para Alonso López Pinciano, Philosophia antigua poética, p. XIV). Sin embargo, Rico Verdú, a diferencia de lo que asegura Calero, no le quita la paternidad de la Philosophia a Pinciano. Según el editor, de la misma forma en la que Platón conservó el conocimiento de Sócrates en sus Diálogos, Pinciano habría preservado las ideas de Fadrique en su poética (vid. id., p. XV). Si bien esto último podría conllevar a interesantes propuestas sobre la forma en la que el Pinciano construyó su poética, no deja de ser poco sostenible la hipótesis de Calero, quien basa su propuesta en el hecho de lo poco que se sabe de la vida de López Pinciano y en las coincidencias de doctrina y estilo que hay entre la obra de Vives y la Philosophia, pues pareciera más bien que el primero fue una fuente directa de la segunda. Habría que realizar un estudio detallado y exhaustivo entre las obras de ambos humanistas para poder confirmar las ideas de Calero y no limitarse a una selección de puntos en común entre las obras de Vives y la Philosophia, como lo hace el hispanista en su trabajo. Este no es ni el lugar ni el momento para realizarlo, pero me parece que incluso las justificaciones de Calero sobre eventos que ocurrieron después de la muerte de Vives y que están presentes en la Philosophia son más bien forzadas, ya que llega a considerar que la "referencia a Felipe II, posterior a Vives, puede ser una interpolación, aprovechando la intervención del valenciano Fadrique" (op. cit., p. 374). Pese a esto, el trabajo de Calero en el rastreo de fuentes de Pinciano es bastante útil.
} 
Clemente San Román 699.

Palau VII, 141819.

Sign.: $\dagger^{4}$, A - $Z^{4}$, Aa $-Z^{4}$, Aaa $-\mathrm{Xxx}^{4}$

Portada con grabados xilográficos, que representa a la Virgen y el niño.

Apostillas marginales.

Escudo heráldico calcográfico con oral tipográfica a toda plana, en v. de portada; son las armas del conde de Frankenbur, Johann IV Khevenhüller de Aichelberg, dedicatario de la obra. ${ }^{4}$

A esto cabría agregar que el ejemplar formó parte "De la Librería del Señor García-Rommo y Echebarria, Oficial de la Real Biblioteca de S. M.", tal y como lo indica el ex libris. El URL de la digitalización es: http:||bdh-rd.bne.es|viewer.vm?id=0000095964\&page=1 y se descargó el 30 de abril de 2019. La portada reporta los siguientes datos:

PHILOSOPHIA | ANTIGVA POETICA | DEL DOCTOR ALONSO | Lopez Pinciano, Medico Cesareo. | Dirigida al Conde Ihoanes Keue[n]hiler de Aichelberg, | Conde de Frankemburg, Baron absoluto de Landts- | cron y de VVernsperg, Señor de Osteruiz y Carls| perg, Cauallerizo Mayor perpetuo y hereditario del | Archiducado de Carinthia, Cauallero de la orden del $\mid$ Tuson del Rey nuestro señor, y del Consejo y | de la Camara del Emperador, $y \mathrm{~s} u \mid$ Embaxador en las | Españas. |EN MADRID, | Por Thomas Iunti. | M. D. XCVI.

De aquí en adelante, cuando cite la poética se colocará entre paréntesis Philosophia-siempre que no se haya especificado con anterioridad-, y el número de folio, indicado con la abreviatura "f." o "fols.", si son varios. En caso de que se cite un folio no numerado se pondrá entre comillas el paratexto al cual se está haciendo referencia con la indicación sin folio (s. f.), ya que estos no tienen otra especificación que oriente al lector.

En cuanto a las ediciones posteriores a la editio princeps, se encuentra la anotada por Pedro Muñoz Peña (Imprenta y Librería Nacional y Extranjera de Hijos Rodríguez, Libreros de la Universidad y del Instituto, 1894). El editor separa las intervenciones y moderniza grafía y ortografía, según las normas del siglo XIX. Su aparato crítico no deja de brindar ciertas informaciones útiles. Por su parte, las ediciones más recientes de la Philosophia fueron realizadas por Alfredo Carballo Picazo (CSIC, 1973, 3 vols.) y por Ricardo Verdú (Fundación José Antonio de Castro, 1998). Ninguna de las dos está anotada, aunque las breves introducciones ofrecen datos interesantes a propósito de la obra y el autor. Ambos editores separan en párrafos los diálogos. Por otro lado, Carballo conserva la grafía original lo más posible, mientras que Ricardo Verdú la moderniza, siguiendo los parámetros de la colección, aunque procura mantener la ortografía, puesto que nota en ella una posible 'voluntad del estilo'5. Todas las ediciones modifican la puntuación.

\footnotetext{
${ }^{4}$ http:||bdh.bne.es|bnesearch|CompleteSearch.do?field=todos\&text=lópez+pinciano\&showYearItems=\&exact $=$ on\&text $\mathrm{H}=\&$ advanced=false $\&$ completeText=\&pageSize $=1 \&$ pageSizeAbrv=30\&pageNumber=2 (consultado el 24/07/2019).

5 "En la Philosophía frente a El Pelayo, encontramos una clara tendencia a mantener la grafía latina (philosophía, scena, sciencia, choro, esencia...); pero, a medida que avanza la obra se introducen grafías vulgares, por lo que cabe
} 


\section{Luis Alfonso de CARVALlo: CisNE DE APOLO (1602)}

La Universidad de Turín, por medio del proyecto de Google Books, pone a disposición del público un testimonio, cuya signatura no específica. En este, pese a estar bien preservado, la tinta ha traspasado las hojas por lo que en algunos pasajes la lectura es imposible. Por su parte, la Biblioteca Virtual del Principado de Asturias digitalizó el testimonio con signatura Ast R49, conservado en la Biblioteca de Asturias "Ramón Peréz de Ayala". La BVPA advierte que el ejemplar tiene pequeñas perforaciones de insectos ${ }^{6}$. La calidad de la imagen es buena, aunque, como ocurre con la digitalización de la Universidad de Turín, en ocasiones la tinta ha traspasado las hojas, pero no se dificulta tanto la lectura como en el primer caso, por lo que decidí usar esta digitalización. La URL es: https:||bibliotecavirtual.asturias.es|i18n|consulta|registro.cmd?id=669 y la descargué el 26 de junio de 2019. La portada anuncia:

CISNE DE APOLO, DE | LAS EXCELENCIAS, Y DIG | nidad y todo lo que al Arte Poetica y versifi- | catoria pertenece. Los metodos y estylos que | en sus obras deue seguir el Poeta. El decoro y $\mid$ adorno de figuras que deuen tener, y todo lo $\mid$ mas a la Poesia tocante, significado por el | Cisne, ynsignia preclara de | los Poetas. | Por Luys Alfonso de Caruallo clerigo. Dedicado | a don Henrique Pimentel de | Quiñones. | Con licencia del Consejo Real. | En Medina del Campo, Por Iuan Godinez | de Millis. Año. 1602. | A costa de Pedro Ossete, y Antonio Cuello.

De aquí en adelante, esta obra se citará entre paréntesis como Cisne, de ser necesario, y el número de folio (f.) más la puntualización de si es recto (r) o vuelto (v), ya que la editio princeps solo numera el recto. En este caso los paratextos sí son distinguidos con calderones (II), por lo que al citarlos se consignará esta grafía.

El único editor contemporáneo del Cisne, Alberto Porqueras Mayo, ha realizado dos ediciones. La primera (CSIC, 1958, 2 vols.) no tiene notas y respeta la grafía de la editio princeps, de acuerdo con las normas de la colección, mientras que la segunda fue mejorada en cuanto al estudio introductorio y a las eruditas notas al texto, casi treinta años después (Reichenberger, 1997). En esta, además, separa los párrafos de las intervenciones de los participantes del diálogo y moderniza la grafía y la ortografía, así como la puntuación.

\section{FRANCISCO CASCALES: TABLAS POETICAS (1617)}

Tanto la digitalización que ofrece la Universidad Complutense de Madrid por medio de Google Books (signatura BH FLL 20384), como la realizada por la Östereichische Nationalbibliothek (signatura 74.X.20) tienen algunos problemas en cuanto a la calidad de la imagen. Por ello, al igual que en el

preguntarse si esta alternancia se debe al propio Alonso López o, como parece más verosímil, que cada tipógrafo cumplía con más o menos rigor el deseo del autor" (op. cit., p. XIII).

${ }^{6} \mathrm{https}$ ://bibliotecavirtual.asturias.es/i18n/consulta/registro.cmd?id=669 (consultado el 24/07/2019). 
caso de la Philosophia, usé la nueva digitalización a color hecha por la BDH -abril de 2019- del testimonio con signatura $\mathrm{R} \mid 4605$, mismo que anteriormente ya se había digitalizado, pero al que le hacían falta las páginas 10 y 44 . La BDH anota: ${ }^{7}$

Marca de impresor en portada que utilizó Agustin Martinez, impresor de Orihuela, Víndel, 441

Sign.: II $-\uparrow \Upsilon^{8}, \mathrm{~A}-\mathrm{Z}^{8}, \mathrm{Aa}-\mathrm{Ee}^{8}$

Grabado xilográfico en verso de $₫ \uparrow^{7}$

La digitalización se descargó el 30 de abril de 2019 de la URL: http:||bdhrd.bne.es|viewer.vm?id=0000079374\&page $=1$. La portada establece la siguiente información:

TABLAS | POETICAS, | DEL LICENCIADO | Fancisco Cascales. | Dirigidas al Excelentissimo Señor Don Francisco | de Castro, Conde de Castro, Duque de Taurisano, | Virrey, y Capitan general del | Reyno de Sicilia. | CON PRIVILEGIO. | En Muria, Por Luis Beros, Año de | M.DC.XVII.

Cuando se cite colocaré entre paréntesis Tablas junto a la página (pag., tal y como aparece en la página 1 de la obra). En caso de citar los paratextos, se sigue un criterio similar al establecido con la Philosophia, ya que el impresor no colocó ningún tipo de señalización en las páginas no numeradas, por ende pongo entre comillas el título del apartado citado y la abreviatura de sin página (s. pag.).

Las Tablas poéticas se imprimieron nuevamente en 1779 por Don Antonio de Sancha, junto a la Epistola Q. Horatii Flacci de Arte Poetica in Methodum redacta, versivus horatianis stantibus, ex diversis tamen locis ad diversa loca translatis, la Novae in grammaticam observationes y el Discurso de la ciudad de Cartagena. La edición tiene por objetivo únicamente recuperar y poner en un solo volumen estas cuatro obras, por lo que agrega un interesante "Prólogo al lector" y adapta la grafía a la época, sin modificar de otra forma la división del texto. Después de esta primera recuperación, las Tablas fueron editadas nuevamente por Benito Brancaforte (Espasa-Calpe, 1975) y posteriormente por Antonio García Berrio (Taurus, 1988), quien realizó un detallado y erudito comentario. Ambos modernizaron la grafía, ortografía y puntuación. En cuanto a la división de párrafos, ninguno de los editores ha tenido que realizarla, ya que desde la editio princeps están bien diferenciadas las intervenciones entre los dos interlocutores del diálogo.

\section{LUIS CARRILLO Y SOTOMAYOR: “LIBRO DE LA ERVDICION POETICA” (1611)}

Entre las cinco poéticas revisadas, el "Libro de la ervdicion poetica" tiene la tradición textual más compleja. Por voluntad de la familia de Carrillo, se publicaron después de su muerte dos ediciones de su operă omnĭa en 1611 y en 1613, a los cuales denominaré como $M_{1}$ y $M_{2}$ respectivamente,

\footnotetext{
${ }^{7}$ http://bdh.bne.es/bnesearch/CompleteSearch.do?field=todos\&text=tablas+poéticas\&showYearItems=\&exact= on\&textH=\&advanced=false \&completeText=\&pageSize=1\&pageSizeAbrv=30\&pageNumber=1 (consultado el 24/07/2019).
} 
siguiendo las siglas establecidas por su traductora y editora italiana Fiorenza Randelli y mantenidas por su editora Angelina Costa. Dentro de estas dos impresiones, el "Libro de la ervdicion poetica" comprende del f. $109 \mathrm{r}$ al f. $139 \mathrm{v}$ en $M_{1}$ y del f. $112 \mathrm{v}$ al f. $151 \mathrm{r}$ en $M_{2}$. En ambos casos se ubica entre la obra poética de Carrillo y Sotomayor -que incluye la traducción de los primeros 396 versos de Remedio amoris, de Ovidio-y sus cartas.

La diferencia en el número de folios obedece a una reorganización del contenido que en el “Libro" se traduce en el aumento de las citas en latín de los textos citados por Carrillo. Sin embargo, según el desconocido corrector de $M_{2}{ }^{8}$, estas no fueron realizadas por el autor, sino por una mano ajena:

Emendose juntamente la puntuacion. Pusieronse las autoridades de autores que se alega[n] en Latin enteras, y de otra letra, y sus interpretaciones en Romance, porque todos los romancistas gozen de la obra. A las autoridades de Poetas traduzidas en verso Castellano no se llego, porque estan muy perfectas. $\left(M_{2}, * * * 4 \mathrm{r}\right)$

En respuesta a esto, he preferido seguir con el criterio de las otras poéticas y usar la editio princeps, aunque siempre teniendo a la mano a $M_{2}$ para cotejar.

De ambos ejemplares existen numerosos testimonios conservados en la Biblioteca Nacional de España, Biblioteca Complutense de Madrid, Biblioteca Provincial de Córdoba, Biblioteca de Andalucía y Biblioteca Nazionale Centrale di Roma ${ }^{9}$. Entre las digitalizaciones realizadas por estas, nuevamente se prefirieron las de la BDH, puesto que su calidad de imagen es mucho mejor que las otras. Así, de $M_{1}$ se consultó la digitalización de la signatura R/3513, URL http:||bdhrd.bne.es|viewer.vm?id=0000078074\&page=1, descargada el 2 de octubre de 2018. Su portada consigna que se trata de las

OBRAS | DE DON LVYS | CARRILLO Y SOTO | MAYOR, CAVALLERO | de la Orden de Santiago, Comen- | dador de la Fuente del Maestre, | Quatraluo de las Galeras de | España, natural de la Ciu- | dad de Cordoua. | A DON MANVEL ALON- | so Perez de Guzman el Bueno, Conde |de Niebla, Gentilhombre de la Camara | de su Magestad, y Capitan Gene- | al de la Costa de An. | daluzia. | CON PRIVILEGIO | En Madrid, Por Iuan de la Cuesta. | Año de M.DC.XI.

${ }^{8}$ Hasta el momento existen dos hipótesis sobre la identidad de este corrector. Por un lado, Fiorenza Randelli y García Soriano creen que fue Alonso Cano Urreta (vid. F. Randelli, "Introduzione" para Luis Carrillo y Sotomayor, Poesie. I. Sonetti, p. 32; Justo García Soriano, apud M. Ortiz Canseco, s. v. "Carrillo y Sotomayor, Luis", en Pablo Jauralde Pou (dir.), Diccionario filológico de literatura española (Siglo XVII), I, p. 278, nota 1). Por otro, el editor de Quevedo, Pablo Jauralde Pou, cree que fue el mismo Francisco de Quevedo el único responsable de todas las correcciones de $M_{2}$ (vid. loc. cit.).

${ }^{9}$ La BNE conserva de $M_{l}$ las signaturas R/4529, R/155, R/14233, R/6132 ex libris de la biblioteca de D. Ferdin. Josephi[n]a Velasco, R/4864, R/19829 ex libris de Pascual de Gayangos, R/9084 ex libris de A. Durán, R/16682; de $M_{2}$ : R/5014 ex libris del licenciado Cayetano Alberto de la Barrera, R/5014, R/6136, U/398, R/27397, 3/35623, 7/12332 (vid. $i d$., pp. 280-281). Y hay al menos un testimonio de $M_{l}$ en la Biblioteca Complutense de Madrid (signatura BH DER 13683), digitalizado por Google Books y uno en la Biblioteca Provincial de Córdoba (signatura 8-206), digitalizado por la Biblioteca Virtual de Andalucía. En cuanto a $M_{2}$, existen cuatro ejemplares en la Biblioteca Complutense de Madrid (signaturas BH FLL Res.501, BH FLL 29195, BH FLL 28175 y BH FOA 150) digitalizados parcialmente también por Google Books y uno en la Biblioteca Nazionale Centrale di Roma (BVEE051565), disponible igualmente por el proyecto de Google Books. 
Por su parte, el testimonio de $M_{2}$, con URL http:||bdhrd.bne.es|viewer.vm?id=0000011000\&page=1 y signatura R|005014(1) - U|398, fue descargado el 2 de octubre de 2018. La portada consigna:

OBRAS [DE] DON | LVYS CARRILLO Y | SOTO MAYOR, COMEN | dador de la Fuente del |Maestre, Quatraluo | de las Gale | ras de Es | paña. | Natural de Cordoua. | A DON MANVEL | Alonso perez de Guzman el bueno, | Conde de Niebla, Capitan general de | la Costa de Andaluzia. | con priuilegio | En Madrid por Luys Sanchez. | P.Perret fe: 1613.

Para citarlas en adelante, se seguirán los criterios ya estipulados: entre paréntesis se colocará $M_{l}$ o en su caso $M_{2}$, el número de folio (f.) y si se trata del recto (r) o vuelto (v). Los paratextos están indicados con estrellas que aquí se cambian con asteriscos (*), como más arriba hice.

Han sido tres los editores modernos interesados en el "Libro". El primero, Manuel Cardenal Iracheta (C.S.I.C., 1946), sigue los parámetros de la Biblioteca de Antiguos Libros Hispánicos y mantiene lo más posible la grafía, los ladillos e incluso la puntuación y división en párrafos de $M_{l}$. Además, en notas al final, consigna las diferencias entre este testimonio y $M_{2}$, con algunas anotaciones sobre puntuación. La edición, en cuanto a la preservación del texto, es la mejor que hay hasta el momento, aunque carezca de notas eruditas, mismas con las que sí cuentan las siguientes dos ediciones hechas por Angelina Costa (Alfar, 1987) y Rosa Navarro (Castalia, 1990). Ambas editoras modernizan grafía, ortografía y puntuación. Sin embargo, Costa fusiona los textos de $M_{1}$ y $M_{2}$, sin avisar en muchas ocasiones en las notas; mientras que Navarro, al igual que Cardenal, conserva a $M_{l}$, señalando en el aparato crítico las variantes de $M_{2}$ y, en ocasiones, los ladillos de $M_{1}$. La edición de Navarro es por demás de gran utilidad por el cuidado que tuvo en el rastreo de fuentes.

\section{JUAN DE JÁUREGUI Y AGUILAR: DISCVRSO POETICO (1624)}

El Discvrso poetico es la única poética de esta investigación de la que se conserva un manuscrito en la BNE (Mss|3980), mismo que, a través de la BDH, se ha digitalizado (URL: http:||bdhrd.bne.es|viewer.vm?id=0000048104\&page=1). Este conserva tanto el Discurso como el Orfeo del poeta. En las notas ofrecidas por el catálogo se advierte que el manuscrito tiene la hoja 42 en blanco ${ }^{10}$. Aunque la calidad de la imagen es bastante buena, existe la misma dificultad que se mencionó con el Cisne; es decir, la tinta ha trasminado el papel, además de haber perdido casi completamente su intensidad y, aunque la caligrafía - bastante apretada- es bastante clara, su lectura en varios momentos es prácticamente imposible. Debido a esto, utilizo la digitalización de la editio princeps proporcionada por la Biblioteca Histórica Marqués de Valdecilla de la Universidad Complutense de

\footnotetext{
${ }^{10} \mathrm{http} / / / \mathrm{bdh} . \mathrm{bne} . \mathrm{es} / \mathrm{bnesearch/CompleteSearch.do?field=todos \& text=discurso+poético \& showYearItems= \& exac}$ $\mathrm{t}=$ on\&text $\mathrm{H}=\&$ advanced=false \& completeTex $\mathrm{t}=$ \&pageSize=1\&pageSizeAbrv=30\&pageNumber=1 (consultado el 25/07/2019).
} 
Madrid -signatura BH FLL Res. 1046(3)-, disponible a través de Google Books (URL https:||books.google.com.mx|books|ucm?vid=UCM5326185337\&printsec=frontcover\&redir_esc=y \#v=onepage\&q\&f=false) y descargada el tres de octubre de 2018. El Catálogo Cisne de la Biblioteca Complutense ofrece los siguientes datos:

Ex libris de la Condesa del Campo de Alange. Sello de la librería de Campo-Alange, 1891. Encuadernado con otras obras. Ingresó en la Biblioteca Histórica procedente de la Facultad de Filología en 2000. Encuadernación de pergamino Digit_GOOGLE Digit_HATHI. ${ }^{11}$

Y la portada del testimonio informa que es el

DISCVRSO | POETICO | De don Iuan de Iauregui. | AL EXCELENTISSSIMO SEÑOR | Don Gaspar de Guzman, Conde de Olivares, | Sumilier de Corps, Cavallerizo mayor, del Con- | sejo de Estado y Guerra de su Magestad, gran | Canciller de las Indias, Alcaide perpetuo | de los Alcaçares de Sevilla, Comendador | mayor de Alcantara,\&c. | CON PRIVILEGIO, | EN MADRID, Por Iuan Gonçalez. | Año M.DC.XXIIII.

Así, en adelante se citará como el resto de las poéticas, entre paréntesis Discurso - de ser necesarioy el número de folio (f.), precisando si es recto (r) o vuelto (v). Los paratextos, como ocurre con la Philosophia, no tienen ninguna grafía que los identifique, por lo que al citarlos se pone entre comillas el apartado al que pertenecen, seguida de la abreviatura sin folio (s. f.).

El Discurso después de 1624 ha sido reeditado en tres ocasiones. La primera fue preparada por la editorial valenciana La fonte que mana y corre (1957) -no indica el nombre del editor. La segunda fue editada por Melchora Romanos (Editora Nacional, 1978), quien modernizó grafía, ortografía y puntuación, además de anotar las fuentes usadas por Jáuregui. La última es una edición digital que La Universidad de París-Sorbona, a través del proyecto Góngora ("Edición digital de la polémica gongorina") de L'Observatoire de la vie littéraire (OBVIL), pone a disposición del público (URL: http://obvil.sorbonne-universite.fr/corpus/gongora/1624_discurso-poetico). La edición la realizó Mercedes Blanco en 2016 y cotejó tanto el testimonio de la Biblioteca Histórica Marqués de Valdecilla de la Universidad Complutense de Madrid, como el ms. 3980 de la BNE. Al igual que Romanos, modernizó grafía, ortografía y puntuación. La división en párrafos de ambas respeta la de la editio princeps. La anotación de Blanco es más detallada que la de Romanos, aunque ambos aparatos críticos son igualmente valiosos por los datos ofrecidos.

\footnotetext{
${ }^{11} \mathrm{https} / /$ ucm.on.worldcat.org/search?lang=es\&clusterResults=off\&stickyFacetsChecked=on\&queryString=dis curso+poético\#/oclc/1025043126 (consultado el 25/07/2019).
} 


\section{N T R O D U C C I Ó N}

Afirma Gracián al inicio de su Agudeza y arte de ingenio (1642) que "Facil es adelantar lo començado: arduo el inventar, y despues de tanto, cerca de insuperable: aunque no todo lo que se prosigue, se adelanta". ${ }^{12}$ Señala así el descuido de la tradición con respecto al concepto primero de la agudeza, luego a la inexistencia de un arte de ingenio $^{13} \mathrm{y}$, como consecuencia, la innovación que está ofreciendo en su tratado. Esta misma acusación y el enaltecimiento de la propia obra los hacen parcialmente los tratadistas italianos de la agudeza como Matteo Peregrini (Delle acutezze, 1639) o Emanuele Tesauro (Il cannocchiale aristotelico, 1654) ${ }^{14}$.

Ahora bien, ateniéndome a ese "començado" de Gracián, me he preguntado hasta qué punto fue "arduo el inventar" del jesuita aragonés en lo concerniente a la agudeza y al ingenio, ya que es innegable toda la tradición clásica que alimentan tanto al tratado del español como al de los italianos, pues sus propias citas y fuentes develan su deuda. Sin embargo, al igual que sucede con conceptos como el de la $\breve{\text { tmĭtâtı̆o }}{ }^{15}$, el Renacimiento, fruto del Humanismo italiano, juega un papel fundamental en la concepción a posteriori de dichas fuentes clásicas. Los humanistas descubrieron redescubrimiento, en ocasiones- y restauraron los textos clásicos. Existió además una importante afluencia de comentarios, glosas, traducciones, paráfrasis e interpretaciones que, junto a los studia humanitatis, cambiaron la concepción de la formación humana y constituyeron el lente (catalejo, diría Tesauro) con el cual se interpretaron a los clásicos, como bien hizo notar Eugenio Garin ${ }^{16}$. Con base

${ }^{12}$ Baltasar Gracián, Obras de Lorenzo Gracian. Tomo segundo que contiente La agudeza, y arte de ingenio. El Discreto. El Politico Don Fernando el Catolico. Meditaciones varias para antes y despues de la Sagrada Comunion, que hasta aora ha corrido con titulo de Comulgador, p. 1.

${ }^{13}$ Ya lo decía el mecenas de Gracián, Vicenzo Giovanni de Lastanosa, en “A los lectores” de El Discreto (1646): "No la prodigiosa Arte de Agudeza, por lo raro, erudito, y ingenioso; que de antes della se tenia por imposible hallarle Arte al ingenio" (Lastanosa, "A los lectores" para El Discreto en Gracián y Morales, Baltasar, Obras de Lorenzo Gracian, divididas en dos tomos. I. El Criticón, tratando en la primera Parte de la Niñez, y juventud: en la segunda de la Varonil Edad, y en la tercera de la Vejez. El Discreto. El Politico Fernando el Catholico. El Heroe, p. 421). Joaquín Rodríguez Beltrán también hace alusión a lo afortunado de esta conjugación "aparentemente paradójica" de ambos términos (vid. Las fuentes antiguas de la agudeza del ingenio en la retórica renacentista, p. 18).

${ }^{14}$ La parcialidad de esta similitud se basa principalmente en la distinción fundamental entre los dos tratadistas italianos y el aragonés: la intención explícita de formular un arte del ingenio. De hecho, mientras en Tesauro no se hace una mención a este propósito - puesto que su objetivo está en determinar la naturaleza, las partes, las causas formales y finales de argutezza-, Peregrini sí intenta establecer un arte, pero que ayudará al ingenio y es propio de este. De aquí que al final de su tratado afirme: "Non prendano con tutto ciò animo alcuno di qua quei bei spiriti che, fidati nella sola robustezza dell'ingegno, disprezzano la notizia dell'arte" (Mateo Peregrini, Delle acutezze, p.160).

${ }^{15}$ Para el desarrollo del concepto de $\breve{m i n t a t} t \grave{o}$ desde los postulados clásicos hasta el Renacimiento es invaluable el trabajo de Ángel García Galiano, La imitación poética en el Renacimiento, Kassel, Publicaciones de la Universidad de Deusto, Reichenberg, 1992.

16 "Non è quindi soltanto la scoperta sempre più larga di testi classici, o lo studio sempre più diffuso del greco, a costituire il punto d'avvio e una componente fondamentale della Rinascita; è il modo di quel ritorno, il mito che vi si costruisce sopra, la forza con cui si rimettono in circolazione le idee, le forme con cui si rettono in circolazione le idee, le forme con cui si interpretarno. Gli 'studia humanitatis' trasformano le scuole di grammatica in scuole di effettiva formazione umana; le arti liberali diventano veramente arti liberatrici, e non nel senso di una liebertà meramente spirituale, ma civile, ma integralmente umana" (Eugenio Garin, La cultura del Rinascimento, p. 26). 
en esto me propongo analizar cinco poéticas ${ }^{17}$ españolas anteriores a Gracián para esclarecer el estado en que se encontraban los conceptos de agudeza e ingenio antes de la publicación del tratado parte aguas del aragonés.

Seleccioné también este corpŭs porque, como señala Margaret Newels, se encuentra inmerso en el "momento en que se admite que las perfecciones retóricas y métricas son, filosóficamente hablando, accidentes, aunque, desde luego, accidentes bien necesarios" ${ }^{18}$. El redescubrimiento de la Poética de Aristóteles -especialmente el fragmento 1451a 36-1451b 11- daba las herramientas suficientes para reflexionar sobre la esencia de la poesía desde una visión filosófica, alejando a los preceptistas de los postulados de Diomedes, quien la subordinaba a la retórica. Entonces, las poéticas españolas escogidas dejan de estudiar el fenómeno poético únicamente a partir de la métrica y como parte de la retórica, consiguiendo una reflexión que dignifica a este arte y a quien lo practica.

Las poéticas que analizaré son pues las siguientes:

1) La Philosophia antigva poetica (1596) de Alonso López Pinciano.

2) El Cisne de Apolo, de las excelencias, y dignidad y todo lo que al Arte Poetica y versificatoria pertenece (1602) de Luis Alfonso de Carvallo.

3) Las Tablas poeticas (1617) de Francisco Cascales.

4) El "Libro de la ervdicion poetica, ò lanças de las Musas contra los indoctos, desterrados del amparo de su deydad" (1611) de Luis Carrillo y Sotomayor.

5) El Discvrso poetico (1624) de Juan de Jáuregui.

No obstante, para un cabal entendimiento del proceso evolutivo de la agudeza y el ingenio y, de cierta forma, en conformidad con la tradición del tratado de corte aristotélico, considero importante establecer tres puntos de partida. Estos, de una u otra manera, permiten conocer el estado de los términos (diccionarios) o si afectaron directamente su desarrollo (fuentes), no solo en las poéticas que se analizarán sino también en el ambiente cultural en el cual se inserta la producción poética. Entonces, presentaré un breve excursus acerca de las definiciones que ofrecen los diccionarios de los siglos XVII y XVIII: el Tesoro de la lengua y Autoridades, para conocer el estado general de ambos términos. Proseguiré con dos poéticas clásicas - pilares inconfundibles de las poéticas de los Siglos de Oro en España-, la Poética de Aristóteles y el Arte poética de Horacio. Finalmente, consignaré

${ }^{17}$ Entiendo por "poética” la definición dada por José Manuel Rico García: "un tipo de tratado que atiende de forma completa al sistema de causas propuesto por Aristóteles, [...] obras que se ocupan de las cualidades que ha de reunir el poeta (causa eficiente), de la finalidad de la poesía (causa final), de la imitatio (causa formal), de la elocución y el estilo (causa material), de los sujetos o asuntos de la poesía y de sus accidentes, es decir, de los elementos de la versificación” (José Manuel Rico García, “Sin poetas hay poéticas': los tratados de preceptiva literaria y el canon en el siglo XVII”, en Begoña Bueno López (coord.), El canon poético en el siglo XVII. Encuentro internacional sobre poesía del Siglo de Oro, pp. 93-94).

${ }^{18}$ Los géneros dramáticos en las poéticas del Siglo de Oro. Investigación preliminar al estudio de la teoría dramática en el Siglo de Oro, p. 42. 
aspectos seminales de la teoría de Huarte de San Juan en torno al ingenio y a la poesía, pues, para los tratados de la época, el Examen de ingenios para las ciencias es sin duda una fuente tan importante como la del estagirita o el latino ${ }^{19}$.

\section{AGUDEZA E INGENIO EN LOS DICCIONARIOS DE LA ÉPOCA}

Si bien el Tesoro de la Lengua Castellana o Española (1611) de Sebastián de Covarrubias Horozco y el Diccionario de la lengua castellana, en que se explica el verdadero sentido de las voces, su naturaleza y calidad, con las phrases o modos de hablar, los proverbios o refranes, y otras convenientes al uso de la lengua, compuesto por la Real Academia Española (1726-1739), son posteriores a algunas o a todas las poéticas que analizo, es importante, como con cualquier término de la época, considerar sus explicaciones, puesto que aquí yacen las bases de cómo se concebía grosso modo el término. Es, además, a partir de estos que, como Mercedes Blanco afirma, "permet de montrer que le mot acquiert précisément à cette époque un sens nouveau" ${ }^{20}$. Por lo que considero que la confrontación entre el Tesoro y Autoridades trae a la luz pequeñas diferencias que pueden ser significativas.

Así pues, Covarrubias consigna la palabra agudeza dentro de la entrada agudo:

Lat. acutus: dizese principalmente del hierro conq[ue] cortamos, o punçamos, y de qualquier otra cosa que corte en esta manera: transfierese al alma, y dezimos agudo al que tiene ingenio sutil, y penetrante. Tambien llamamos agudo al inquieto que anda de aqui para alli bullendo. Aguda vista, la que alcança a ver muy de lexos, como del Aguila. Dar de agudo, lastimar con palabras, que penetran hasta el coraçon; como el que hiere de punta. Agudeza, sutilidad. ${ }^{21}$

\section{Mientras que ingenio:}

Latine ingeniu[m], à gignendo, proprie natura dicitur cuique ingenita, indoles. Vulgarme[n]te llamamos ingenio vna fuerça natural de entendimiento, inuestigadora de lo que por razon y discurso se puede alcançar en todo genero de ciencias, diciplinas, artes liberales, y mecanicas, sutilezas, inuenciones, y engaños: y assi llamamos ingeniero al que fabrica maquinas para defenderse del enemigo, y ofenderle: ingenioso, el que tiene sutil y delgado ingenio. Las mismas maquinas inue[n]tadas con primor llamamos ingenios [...]. Finalmente qualquiera

\footnotetext{
${ }^{19}$ La brevedad del excursus que expongo responde en primer lugar a las necesidades del corpŭs, por ello indico sus principales fuentes, mas no las únicas, como cabe suponer de unas poéticas inmersas en el eclecticismo renacentista. Asimismo, responde a la existencia de trabajos que preceden al presente y que dan una detallada descripción de la tradición de ambos términos. Me refiero a las tesis doctorales de Víctor Fernández-Corugedo, El ingenio desde los Presocráticos hasta Gracián (1998), y Joaquín Rodríguez Beltrán, Las fuentes antiguas de la agudeza del ingenio en la retórica renacentista (2017).

${ }^{20}$ Mercedes Blanco, Les Rhétoriques de la Pointe. Baltasar Gracián et le Conceptisme en Europe, 1992, p. 11. Es cierto que el trabajo de Blanco se centra en el estudio de los tratados de Gracián, Tesauro, Peregrini y Pallavicino; sin embargo, su intuición me parece también aplicable al presente trabajo, pues precisamente es su objetivo conocer la transformación de estos y otros conceptos en los albores del Barroco.

${ }^{21}$ Sebastián de Covarrubias Horozco, Tesoro de la lengva castellana, o española, $s . v$. agudo (disponible en línea: http://fondosdigitales.us.es/fondos/libros/765/descargar/tesoro-de-la-lengua-castellana-o-espanola/).
} 
cosa que se fabrica con entendimiento, y facilita el executar lo que co[n] fuerças era dificultoso y costoso, se llama ingenio. ${ }^{22}$

Inmediatamente observamos que mientras agudeza -nótese que en la entrada aparece como adjetivo- se refiere a la invención humana solo por transferencia, es decir como metáfora. Por su parte, ingenio posee como primera acepción su carácter de "fuerça natural de entendimiento". Esto se explica por la tradición clásica implícita en ambas definiciones. Mientras ăcūtus y ăcūmĕn eran términos figurados, relacionados en la tradición latina con elementos más sensoriales (como el estilo) ${ }^{23}$, ingěnŭum ya estaba relacionado con el talento y la capacidad del ser humano para crear $^{24}$, que es precisamente como lo recuerda Fernando de Herrera en su anotación al verso 948 de la "Égloga II" de Garcilaso:

es aquella fuerça i potencia natural, i aprehension facil i nativa en nosotros, por la cual somos dispuestos a las operaciones peregrinas i a la noticia sutil de las cosas altas. procede [sic] del buen tempera[m]ento del animo i del cuerpo. significa [sic] propriame[n]te aq[ue]lla virtud del animo i natural abilidad; nacida co[n] nosotros mesmos, i no adquirida con arte o industria. llaman [sic] los Griegos i Latinos ingenio a la naturaleza de cualquiera cosa. ${ }^{25}$

Es pues "fuerça i potencia natural", como ya en cierta forma Antonio de Nebrija había establecido: fuerza natural ${ }^{26}$. Pero no solo esto, pues tanto el Tesoro como Herrera relacionan al ingenio con la sutileza, sinónimo de agudeza. Asimismo, esta se asocia estrechamente con el ingenio. Sin embargo, hay que recalcar que pareciese que el ingenio es, por su cualidad natural, innato al ser humano, mientras que la agudeza no es así. Agudo es propio del que posee un tipo determinado de ingenio, a saber "al que tiene ingenio sutil, y penetrante" o "al inquieto que anda de aqui para alli bullendo". De la misma forma, el ingenio solo crea sutilezas "por razon y discurso". Por lo tanto, puedo deducir tres puntos de estas definiciones: 1) agudeza e ingenio están estrechamente ligados, si

\section{${ }^{22} I d ., s . v$. ingenio.}

${ }^{23}$ Dice Merecedes Blanco “Acutus (aigu, pointu, perçant) a déjà en latin un valeur figurée, celle de fin, subtil, adroit, qui lui permet de qualifier un homme (homo acutus, homme fin, Cicéron: Verr., 2, 128) et aussi un syle oratoire" (M. Blanco, op. cit., p. 36). Y más adelante: "Les mots latins acutus, acumen, impliquent donc un maigreur de l'expression, un dédain marqué des aspects les plus sensuels du style, euphonie, diversité des rythmes, épithètes, mots rares et notations sensorielles" (id., p. 37). Es también del 'estilo agudo’ de donde parte la tesis de Rodríguez Beltrán: “A finales del siglo XVI y principios del XVII se comenzó a gestar una tendencia retórica y filosófica que intentó poner en práctica un ideal literario del 'estilo agudo' e incluso teorizar sobre él. Surgió de manera más acentuada en el mundo cultural hispánico y en el italiano, aunque también tuvo importancia en el medio anglosajón y en el neolatino" (op. cit., p. 13). A propósito del carácter estilístico, véase también Ernst Robert Curtius, Literatura europea y Edad Media latina, I, p. 412 y Heinrich Lausberg, Manual de retórica literaria. Fundamentos de una ciencia de la historia, para ăcūměn $\S 1079$, 1с y ăcūtus, principalmente $\$ 540$, en donde es evidente que forma parte de una virtud del discurso.

${ }^{24}$ Vid. id., especialmente $\$ 6, \S 1151-\S 1154$.

${ }^{25}$ Fernando de Herrera, Obras de Garci Lasso dela Vega con anotaciones de Herrera, f. 581; disponible en línea: http://www.cervantesvirtual.com/obra-visor/obras-de-garcilasso-de-la-vega--0/html/ff83d41a-82b1-11df-acc7-

002185ce6064_77.htm). Mercedes Blanco en su rastreo del término entre los clásicos encuentra que ingenio es una cualidad natural y que el término al ser aplicado a un ser humano designa o su carácter o su capacidad nata (vid. M. Blanco, op. cit., p. 25). Es evidente que Herrera recupera la primera y la última acepción, mientras que en los diccionarios prevalece la tercera.

${ }^{26}$ Vid. Joan Corominas, Diccionario crítico etimológico de la lengua castellana, s. v. "genio". 
y solo si 2) hay un determinado tipo de ingenio, en cuyo caso la agudeza es una cualidad de este; además 3) el ingenio que genere sutileza debe estar cultivado o adoctrinado.

Similares a estas definiciones son las que están en Autoridades, obra posterior a la producción graciana, una de las auctoritates que se usan en el diccionario. Aquí, agudeza -con una entrada propia- se define como

Sutileza, y delicadeza con que están afilados los cortes, ò las puntas de algunos hierros, armas, instrumentos, ù otras cosas. Lat. Acumen. GRAC. Mor. fol. 198. Las Aguilas y Leónes quando andan de passéo, retornan las uñas hacia dentro por no gastar los filos y agudéza de ellas. Metaphoricamente: la sutileza, prontitúd y facilidád de ingénio en pensar, decir ò hacer alguna cosa. Lat. Perspicacitas. Acumen. ${ }^{27}$

E ingenio se define como

Facultad o poténcia en el hombre, con que sutilmente discurre o inventa trazas, modos, máchinas y artificios, o razones y argumentos, o percibe y aprehende fácilmente las ciéncias. Viene del Latino Ingenium. MARIAN. Hist. Esp. lib. 7. cap. 15. Hombre docto y de ingénio agúdo. SAAV. Empr. 84. Segúra es la guerra que se hace con el ingénio; y peligrosa y incierta la que se hace con el brazo. Se toma muchas veces por el sugeto mismo ingenioso: y assí se suele decir de las comedias de un ingénio, de dos o tres ingénios. Latín. Ingeniosus homo. QUEV. Entremet. El Poeta de los pícaros se fue a revestirse en el cuerpo de los Poetas mechánicos, Ingénios cantoneros, y Musas de alquiler como mulas. Se toma tambien por las mismas trazas, mañas o artes de que se usa para conseguir alguna cosa. Latín. Machina. Artificium. ${ }^{28}$

Las definiciones en sí no cambian fundamentalmente, puesto que agudeza sigue vinculada con ingenio de forma metafórica e ingenio sigue siendo una facultad o bien potencia, aunque ya no se especifique que es natural. Sin embargo, es relevante que en Autoridades el ingenioso ya tiene también una connotación relacionada con el teatro, es decir, con una producción propiamente literaria. Además, la relación entre agudeza e ingenio ya no se condiciona, pues el ingenio ya "sutilmente discurre" sin necesidad de "razon y discurso" y agudeza ya es por traslación una cualidad, pareciera, inherente al ingenio.

Sin detenerme más en estas distinciones, baste ahora anotar que es evidente la transformación de ambos términos, tal vez no de forma abrupta, pero sí sustancial. Además, con ambas definiciones se puede también observar la interrelación tan importante que desde el siglo XVII existe entre los términos.

${ }^{27}$ Diccionario de la lengua castellana, en que se explica el verdadero sentido de las voces, su naturaleza y calidad, con las phrases o modos de hablar, los proverbios o refranes, y otras convenientes al uso de la lengua, s. $v$. agudeza (disponible en línea: http://web.frl.es/DA.html).

${ }^{28}$ Id., s. v. ingenio. 


\section{AGUDEZA E INGENIO PARA EL MUNDO CLÁSICO: ARISTÓTELES Y HORACIO.}

Las definiciones en los diccionarios de la época subrayan la dependencia de los conceptos respecto del mundo clásico. Por tal motivo, Herrera en sus Anotaciones aclara de qué manera los griegos y romanos los concebían, a quienes él mismo usó como base para, de forma ecléctica, ofrecer una glosa a la poesía de Garcilaso. Entre estos clásicos griegos y romanos quiero destacar dos: la Poética de Aristóteles y la Epístola a los Pisones, mejor conocida como Arte poética de Horacio ${ }^{29}$.

Estas dos fueron las piedras angulares de las poéticas de los siglos XVI y XVII, de aquí que Marcelino Menéndez Pelayo, en su Historia de las ideas estéticas en España, comente a propósito de su división en preceptistas clásicos y apologistas: "Pondremos en el primer grupo a los preceptistas clásicos; quiero decir, a los que tomaron por base de sus especulaciones la Poética, de Aristóteles o la de Horacio, o entrambas a la vez" ${ }^{30}$. Dicha interrelación -mejor lograda en unos que en otros, como se verá a lo largo del trabajo- marca la pauta tanto a preceptistas como a poetas, puesto que forma un "hilo conductor" entre ellos, como bien apunta Angelina Costa ${ }^{31}$. A la luz de esto, resulta obligado revisar ambas obras para seguir las pistas que puedan dar a propósito de la agudeza y el ingenio.

\section{La agudeza}

La Poética de Aristóteles muestra una aparente carencia de definición de agudeza. De hecho, etimológicamente, la palabra no está asociada al griego, sino al latín, como se vio más arriba. ¿Existe entonces algún término griego asociar a la agudeza? Tal vez no en la Poética, pero sí en la Retórica ${ }^{32}$, en particular en el libro III, como lo demuestra Emanuele Tesauro al inicio de su Cannocchiale aristotelico. En el apartado "Nome dell'argutezza”, del primer capítulo "Dell'argutezza, et de' suoi parti. In generale", el italiano enuncia la tradición etimológica de la argutezza -nombre que el italiano da a la agudeza-, en griego, con sus equivalencias en latín, italiano y, en un par de ocasiones, en

\footnotetext{
${ }^{29}$ Se sabe que desde la época romana la Epístola a los Pisones se conoció con el nombre de Arte Poética, tal es la constancia que tenemos en Quintiliano en su Instituciones oratoria (vid. Trasicio Herrera Zapién, "Introducción" para Quinto Horacio Flaco, Arte poética, pp. XIII-XIV). Además, fue así como la conocieron los tratadistas del Renacimiento y Barroco. Baste como prueba la breve digresión que hace en torno al título Francisco Cascales en sus Tablas poeticas, cuando Piero, uno de los interlocutores del diálogo, pregunta a Castalio por qué se le ha dado el nombre de Poética a la obra de Horacio, a lo cual Castalio responde: “O, bien sea por arbitrio y juicio d[e] los Gramaticos, ò por parecer de los Impressores, q[ue] no en pocas cosas se suelen tomar algunas libertades, ese titulo d[e] Poetica se le [h]a dado, y confirmado con millares de impressiones" (Tablas, pags. 5-6). Se observe, por otro lado, la primacía que da Cascales a la obra de Horacio al hacer puntual énfasis - si bien hiperbólico- en su gran difusión con "millares de impressiones".

${ }^{30}$ Marcelino Menéndez Pelayo, Historia de las ideas estéticas en España, II, Siglos XVI y XVII, pp. 205-206.

${ }^{31}$ Dice Angelina Costa: “entre las ideas estéticas de la época existe un hilo conductor derivado de la común interpretación que de los preceptos aristotélicos y horacianos habían hecho los exégetas italianos. De aquí la concurrencia de pensamiento entre las Anotaciones de Herrera, el Libro de la Erudición de Carrillo y el Discurso poético de Jáuregui” ("Introducción” para Luis Carrillo y Sotomayor, Poesía completas, p. 31).

${ }^{32}$ No debe extrañar que se deba recurrir a la Retórica porque, como es bien sabido, Aristóteles mismo había concebido la Poética como parte complementaria de la Retórica. No quiero decir con esto que la Poética sea un apéndice o apartado de la Retórica, sino que ambas se complementan. Como ejemplo de esto están las múltiples llamadas que hace Aristóteles a la Poética durante la Retórica.
} 
francés. En el caso particular del griego, el tratadista turinés ofrece una serie de asociaciones al latín que están más relacionados con aspectos retóricos como son las figurae, el ornatum o bien con las urbanitas, equivalentes, según Tesauro, a los términos griegos schemata, cosmiotin y asteia, respectivamente ${ }^{33}$.

Con base en lo anterior, observo que, al igual que en la tradición latina, los posibles términos griegos de corte aristotélico asociados con agudeza son de orden más bien estilístico, como, por ejemplo, las figuras retóricas. De estas últimas, tanto en la Poética (1457a 31-1458b 17) como en la Retórica, hay una en particular que puede indicar una posible semilla de lo que será la agudeza: la metáfora. Aristóteles considera que las metáforas "hay que obtenerlas de cosas apropiadas, pero no evidentes, igual que en filosofía es propio del sagaz establecer la semejanza <de dos cosas>, aunque sean muchas sus diferencias" (Ret., III, 11, 1412a 12-14) ${ }^{34}$. Este es precisamente el principio en el que se basa la definición de agudeza en el siglo XVII ${ }^{35}$. Así, análogamente, se recupera en el “Discurso II" del emblemático tratado de Baltasar Gracián: “Consiste pues este artificio conceptuoso en una primorosa concordancia, en una armonica correlacion entre dos, ò tres cognoscibles extremos, expressada por un acto del entendimiento" "36. La permanencia de Aristóteles es evidente.

En lo que respecta al Arte poética de Horacio, las palabras acutum y ăcūmĕn aparecen dos veces la primera y una la segunda. Acutum está en el v. 304 -la idea completa comprende los vv. 304308- e implica el significado de la primera acepción del Tesoro y de Autoridades:

[...] Ergo gungar uice cotis, acutum reddere quæ ferrum ualet exsors ipsa secandi; munus et officium, nil scribens ipse, docebo, unde parentur opes, quid alat formetque poetam, quid deceat, quid non, quo uirtus, quo ferat error. ${ }^{37}$

El significado de "agudo" como "puntiagudo o afilado", empero, adquiere también un significado figurativo, pues Horacio, con una metáfora, asevera que será la "piedra que puede agudo volver el hierro". En otras palabras, el poeta latino, como profesor, volverá agudo a quien leyese su poética, en tanto que penetrará con lo filoso de su entendimiento en los principios del arte poética. Mientras que el hierro puede ser interpretado como el ingenio del receptor.

\footnotetext{
${ }^{33}$ Vid. Emanuel Tesauro, Il cannocchiale aristotelico o sia Idea dell'arguta et ingegnosa elocutione che serve à tutta l'arte oratoria, lapidaria, et simbolica. Esaminata co' principii del divino Aristotele, pp. 4-9.

${ }^{34}$ Aristóteles, Retórica, Quintín Racionero (trad. y ed.), p. 541.

${ }^{35}$ La metáfora será primordial para el tratado de Tesauro, quien le dedica una parte importante del Cannocchiale, “Trattato della metafora" (vid. E. Tesauro, op. cit., pp. 166-481). Por su parte, Peregrini usa la definición de Aristóteles como propia de la acutezza (vid. M. Peregrini, op. cit., p. 37).

${ }^{36}$ B. Gracián, Obras de Lorenzo Gracian. Tomo segundo..., p. 6.

37 "Por ello haré las veces de piedra que puede / agudo volver el hierro, incapaz de cortar ella misma; / tarea y deber enseñaré, nada yo mismo escribiendo, / de dónde se tomen recursos, qué nutra y forme al poeta, / qué convenga, qué no, a dó el mérito, a dó el error encamine” (Q. Horacio, Arte poética, Tarsicio Herrera Zapién, trad. y ed., p. 14).
} 
Su segunda aparición se refiere únicamente al sonido contrario al grave: "nam neque chorad sonum Reddit quem uolt manus et mens, / poscentique grauem persæpe remittit acutum" (v. 348$349)^{38}$. Esta acepción no aparece en ninguna de los dos diccionarios de la época. Sin embargo, tendrá un valor importante en la prosodia de la teoría métrica de las poéticas de los siglos XVI y XVII.

Acumen (v. 364), por su cuenta, se incluye en uno de los pasajes más célebres del Arte poética: “Ut pictura pœsis" (vv. 361-365) y su implicación es de suma importancia, puesto que acumen es una característica con la cual el judicis valora el producto artístico:

Ut pictura pœsis; erit quæ, si propius stes, te capiat magis, et quædam, si longius abstes ; hæc amat oscurum, uolet hæc sub luce uideri, judicis argutum quæ non formidat acumen ; hæc placuit semel, hæc deciens repetita placebit. ${ }^{39}$

Acumen, argutum además, es entonces aquí una cualidad no del ingenio sino del judicis. Esto podría dar una pista del por qué juicio e ingenio se relacionaron a lo largo del Renacimiento y aún más durante el Barroco. De tal manera, señala Mercedes Blanco, desde Juan de Encina, entendimiento, discreción, ingenio y juicio son en cierta forma sinónimos, aunque para el siglo XVII ya existía una plena distinción entre estos y era incluso patente la contraposición entre los dos últimos, precisamente el ingenio y el juicio ${ }^{40}$. En consecuencia, desde Horacio observo ya la potencialidad de ăcūměn para que se vuelva una cualidad de una facultad intelectual, hecho que se cristaliza a lo largo del siglo XVI y llega a su culmen en el XVII con la asociación indisoluble de agudeza e ingenio.

\section{El ingenio}

Con una clara alusión al furor poético del Ion platónico ${ }^{41}$, Aristóteles en 1455a 32-34 de su Poética afirma que en la poesía pueden existir dos tipos particulares de poetas: "el arte de la poesía es de hombres de talento o de exaltados; pues los primeros se amoldan bien a las situaciones, y los segundos

\footnotetext{
38 "pues ni la cuerda da el tono que quieren la mano y la mente, / y muy seguido al que pide uno grave la emite un agudo" (id., p. 16).

39 “Cual la pintura es la poesía; una hay que, si más cerca te hallas, / más te cautiva, y alguna, si más lejos te apartas; / ésta ama lo obscuro, querrá con luz ser mirada esa otra / que no tiembla del juez ante la astuta agudeza; / ésta una vez gustó, ésa gustará repetida diez veces" (id., p. 17).

${ }^{40}$ Vid. M. Blanco, op. cit., p. 30-33.

${ }^{41}$ Ion 533e-534a: "pues todos los buenos poetas épicos dicen todos estos bellos poemas, no apoyándose en arte, sino inspirados y poseídos por la divinidad, y los buenos poetas líricos lo mismo; así como los coribantes no danzan cuando están en su juicio, tampoco los poetas líricos componen estos bellos cantos cuando están cuerdos, sino que, después de haber penetrado en la armonía y en el ritmo, caen en éxtasis y, poseídos, del mismo modo que las bacantes sacan miel y leche de los ríos poseídas, pero en su juicio no, también el alma de los poetas líricos hace esto, como ellos mismos dicen. Nos dicen, en efecto los poetas que jardines y bosquecillos de las Musas como las abejas, volando también ellos de este modo. Y dicen verdad. Es, en efecto, cosa leve un poeta, y alada y sacra, y no es capaz de componer hasta que se apodera de él la divinidad y pierde el juicio y sale de él la razón" (apud Valentín García Yebra, Poética de Aristóteles. Edición trilingüe, pp. 303-304, n. 249). La teoría del furor poético es también expuesta en la Apología, el Banquete, Fedro y Leyes de Platón.
} 
salen de sí fácilmente" ${ }^{42}$. El fragmento, inserto en lo que García Yebra denomina "Consejos a los poetas", muestra que hay dos posibilidades de crear la fábula y perfeccionarla. La primera es a través de la observación y la segunda dejándose llevar por el furor. Tal división, pese a tener ecos de la teoría platónica y a no vincularse directamente con los principios que establece Horacio en Arte poética a propósito del ingenio -como insiste Antonio García Berrio ${ }^{43}$-, sí establece, a mi parecer, dos vías para la producción poética que preludian de cierta forma una de las dualidades tan comentadas en las teorías renacentistas -magistralmente explicada por el mismo García Berrio ${ }^{44}$-: ingenio y arte $^{45}$, que se podría reducir ahora a la cuestión de si un poeta nace o se hace.

En el Arte poética de Horacio se puede ubicar el término ingěnĭum en tres ocasiones. La primera vez para criticar irónicamente a un tipo de poeta pseudo furioso; pseudo porque tal poeta, en la figura de Demócrito, no está inspirado, sino que dicho personaje solo basa sus "dotes poéticos" en el acoplamiento de su persona a un determinado lugar común:

Ingenium misera quia fortunatius arte
credit et excludit sanos Helicone poetas
Democritus, bona pars non unguis ponere curat,
non barbam, secreta petit loca, balnea uitat;
nanciscetur enim pretium nomenque poetæ,
si tribus Anticyris caput insanabile nunquam
tonsori Licino commiserit. (vv. 295-301)

La prevalencia en este punto del arte sobre el ingenio se debe principalmente a la crítica de sus contemporáneos que incluso consideran al arte como algo reprensible (“del Helicón excluye a los poetas sensatos").

Por el contrario, en las otras dos apariciones del ingěnĭum se restablece su importancia dentro del quehacer poético. Así, Horacio alaba el ingenio que la Musa dio a los griegos en los vv. 323-24:

${ }^{42} I d .$, p. 188.

43 "Aristóteles se limitaba aquí a recoger la tradición del poeta furioso del Ion platónico, como alternativa de su propia afirmación. El texto citado está precedido de una invitación de Aristóteles a los poetas a que se pongan en lugar de sus personajes y estudien las soluciones e impulsos de su propia naturaleza: invitación fundamentada, claro está, en el principio de la básica identidad universal de la naturaleza humana" (Antonio García Berrio, Formación de la Teoría Literaria moderna, 1, La tópica horaciana en Europa, p. 239).

${ }^{44}$ Vid. id., pp. 237-311.

${ }^{45}$ Hago esta afirmación con la debida distancia que existe entre las dos poéticas clásicas. Cosidero desde la diferente concepción que Aristóteles y Horacio tenían del arte, enunciada por García Berrio (vid. id., p. 239), hasta la hipótesis hecha por García Yebra que sugiere que Horacio no conoció directamente la Poética de Aristóteles, a causa de la propia tradición manuscrita del texto (vid. García Yebra, op. cit., p. 12). Sin embargo, el traductor del estagirita sí señala el conocimiento de Horacio de fuentes dependientes de las doctrinas aristotélicas, por lo que es posible establecer una línea de tradición, si no directa, sí indirecta.

46 "Porque cree que es más afortunado el ingenio que el arte / mísero, y del Helicón excluye a los poetas sensatos / Demócrito, buena parte no procura uñas ni barba / ordenar, busca lugares secretos, evita los baños; / pues alcanzará de poeta el mérito y nombre, / si la cabeza incurable por tres Anticiras no encarga / al barbero Licino" (Q. Horacio, op. cit., p. 14). 
"Grais ingenium, Grais dedit ore rotundo / Musa loqui, præter laudem nullius auaris" $"$. Por su parte, los vv. 408-411 aseguran la importancia que el ingenio tiene para el arte, estableciendo la cooperación y casi dependencia entre ambos:

Natura fieret laudabile carmen an arte,

quæsitum est ; ego nec studium sine diuite uena

nec rude qui prosit uideo ingenium; alterius sic

altera poscit opem res et conjurat amice. ${ }^{48}$

La relación arte-ingenio "quedaba planteada en Horacio de este modo como una fervorosa disyuntiva, que venía a enmascarar en el fondo una doble adhesión a ambos principios como doble causa eficiente del hecho literario"49.

Efectivamente, las entidades del arte y del ingenio quedan delimitadas, sin que por esto haya una imposibilidad de trabajo en conjunto para el latino. Además, es oportuno señalar también la relación que en estos versos se hace de ingěnŭum con natura, pues es esta la que hace el "carmen laudable". Esta relación muy probablemente se deba al resultado de una metonimia, pues ya Horacio en el verso 108 afirma que "Format enim natura prius nos intus ad omnem" 50 . Es la naturaleza entonces la que manda dentro de nosotros y, por tal motivo, es también ella quien da el ingěnĭum a los poetas ${ }^{51}$. Este razonamiento es recordado por Herrera en sus Anotaciones y, aunque por una tradición diferente a la horaciana, es esencial también para la obra de Juan Huarte de San Juan ${ }^{52}$, lo que marca la importancia que este principio tuvo en toda la tradición renacentista.

\section{INGENIO EN LA TEORÍA DE JUAN HUARTE DE SAN JUAN}

Las numerosas impresiones, ediciones y traducciones desde la editio princeps de Examen de ingenio para las ciencias (1575) y las constantes referencias directas o indirectas que contemporáneos y legatarios ${ }^{53}$ hacen del texto de Huarte de San Juan constituyen un punto de referencia al hablar de ingenio, puesto que sus teorías retoman eclécticamente la tradición clásica y la reformulan para darle

\footnotetext{
47 “A los griegos ingenio, a los griegos dio con boca rotunda / hablar la Musa, más que de alabanza, de nada ambiciosos" (id., p. 15).

48 "Si por naturaleza se hace un carmen laudable o por arte, / se ha preguntado; yo no veo de qué sirve el esfuerzo / sin rica vena ni el ingenio rudo; así una cosa / pide el auxilio de la otra y se asocia amigablemente" (id., p. 19).

${ }^{49}$ García Berrio, op. cit., p. 240.

50 "Pues antes natura nos forma dentro según todo aspecto" (Q. Horacio, op. cit., p. 5).

${ }^{51}$ García Berrio revisa la relación ingěnŭum y natura (vid. op. cit., pp. 239-240), pero sin detenerse en las razones a las cuales esta se deba.

52 Sobre las fuentes de Huarte vid. Guillermo Serés, "Introducción” para Juan Huarte de San Juan, Examen de ingenios para las ciencias, G. Serés (ed.), pp. 70-107, en donde quiero resaltar las fuentes aristotélicas.

${ }^{53}$ Entre las poéticas que estudio, hay al menos dos de ellas que basan algunos de sus principios en el tratado de Huarte de forma directa. Por tal motivo, el estudioso Sanford Shepard no inicia el estudio de la Philosophia de Pinciano sin antes dar buena cuenta de la deuda que este tiene con la teoría de Huarte (vid. El Pinciano y las teorías literarias del siglo de oro, pp. 28-40). Asimismo, Carvallo en su Cisne de Apolo, pese a citarlo solo tres veces directamente, está profundamente influenciado por las doctrinas huartianas (vid. Alberto Porqueras Mayo "Introducción” para Luis Alfonso de Carvallo, Cisne de Apolo, A. Porqueras Mayo ed., p. 20).
} 
una nueva visión. De tal manera, como haría Gracián casi a mitad del siglo XVII, Huarte enuncia su novedad:

Todos los filósofos antiguos hallaron por experiencia que donde no hay naturaleza que disponga al hombre a saber, por demás es trabajar en las reglas del arte. Pero ninguno ha dicho con distinción ni claridad qué naturaleza es la que hace al hombre hábil para una ciencia y para otra incapaz, ni cuántas diferencias de ingenio se hallan en la especie humana, ni qué artes y ciencias responden a cada uno en particular, ni con qué señales se había de conocer, que era lo que más importaba. ${ }^{54}$

Huarte, en concordancia con lo que ocurría en el Segundo Renacimiento ${ }^{55}$, se dispone a hacer un arte a través de su examen de los diferentes tipos de ingenios. De tal forma, en la edición expurgada de $1594^{56}$, el médico inicia su trabajo con el nombre de su objeto de estudio. En consecuencia, afirma entimológicamente: “ingenio, desciende de uno de estos tres verbos latinos; gigno, ingigno, ingeniero; y de este último parece que tiene más clara su descendencia, atento a las muchas letras y silabas que de él vemos que toma, y lo que su significación diremos después"57.

Con intuición etimológica, Huarte se acerca a dos de los términos latinos que el Tesoro después contempla. A partir de esto, sigue la creación de la palabra -sin especificar cómo ocurrió- y considera al ingenio como potencia. De tal guisa, lo relaciona con el entendimiento, pues este es "potencia generativa" $" 58$ " "tiene virtud y fuerzas naturales de producir y parir dentro de sí un hijo, al cual llaman los filósofos naturales noticia o concepto, que es verbum mentis" ${ }^{\text {"59 }}$. Entonces, para Huarte el ingenio es afín al entendimiento, pues ambos ayudan a la generación y creación de conocimiento.

Con base en lo anterior, establece que Genio -apelativo que según Huarte los filósofos naturales dieron a Dios- "por antonomasia quiere decir el grande engendrador" 60 , lo que hace del ingenio una capacidad incluso divina ${ }^{61}$. Es importante además esta definición porque tiene ya dentro de sí la creación de conceptos, término de suma importancia para la poética barroca y la teoría de Gracián, aunque es considerado aquí como verbum mentis, equiparable al significado saussuriano.

${ }^{54}$ J. Huarte de San Juan, op. cit., pp. 153-154.

${ }^{55}$ Con respecto a esto dice Serés; "la actividad y el método del ensayista contemporáneo de Huarte van a tender a la sistematización enciclopédica, al estudio compartimentado y a la clasificación exhaustiva de los saberes. Se codifican, se logicifican, tanto los casos de conciencia (es la edad de oro de la casuística), como la fisonomía, la poesía, la retórica, l'arte dello stato, la observación de la naturaleza en general, etc.; y, por supuesto, el estudio de los temperamentos o de las complexiones, el examen de las habilidades individuales, de las vocaciones profesionales" (G. Serés, op. cit., pp. 1921).

${ }^{56}$ Para las ediciones de Examen de ingenios, véase siempre el trabajo de Serés (id., pp. 108-109). En la presente introducción tomo en cuenta tanto la edición de 1575 como la de 1594 porque, en principio, todas las poéticas analizadas son posteriores a la edición expurgada y, luego, porque aquí es mi objetivo dar una visión sucinta y general de los planteamientos de Huarte.

${ }^{57}$ J. Huarte de San Juan, op. cit., p. 186.

${ }^{58}$ Id., p. 187.

${ }^{59}$ Id., p. 188.

${ }^{60} I d$., p. 189.

${ }^{61}$ De hecho, esto ya se intuye antes cuando habla de las dos potencias generativas del ser humano, "una común con los brutos animales y plantas, y otra participante con las sustancias espirituales, Dios y los ángeles" (id. 187). 
Así pues, concluye Huarte: "Y esto baste en cuanto al nombre de ingenio, el cual desciende de este verbo ingeniero, que quiere decir engendrar dentro de sí una figura entera y verdadera que represente al vivo la naturaleza del sujeto cuya es la ciencia que se aprende"62.

Después, Huarte hace un excursus por los clásicos, pasando por Aristóteles, Galeno y Cicerón para encontrar los diferentes tipos de ingenio: el primero corresponde a la docilitas, propio del que necesita un profesor y libros; el segundo es el optimum ingenium que comprende todo por sí mismo; y el tercero corresponde al furioso de Platón rescatado por Aristóteles en su Poética, el ingenium excellens cum mania, que es aquel que tienen revelaciones divinas ${ }^{63}$. Sin embargo, para este último da una explicación galénica, ya que, como filósofo natural, Huarte busca las causas de las cosas, sin atenerse por esto a una explicación meramente divina ${ }^{64}$, por tal motivo este ingenium excellens cum mania es explicado a través de la destemplanza del temperamento, principalmente el caliente ${ }^{65}$.

El Examen, siguiendo una tradición clásica, explica pues el ingenio y el temperamento del poeta, que se encuentra estrechamente ligado a la potencia humana de la imaginación ${ }^{66}$, dependiente asimismo del calor, como explica Felice Gambin: "El vínculo entre imaginación, poesía y calor que ésta última necesita, vínculo antiquísimo como la relación entre poesía, inspiración, rapto, entusiasmo es un topos" ${ }^{\prime 67}$. Sin embargo, este calor, para Huarte-que sigue siempre de cerca a Galeno-, es nocivo para el "hombre hábil", quien es tal gracias al "cerebro bien templado, con moderado calor" ${ }^{68}$. De aquí se desprende el poco prestigio que tiene el poeta en Examen de ingenios ${ }^{69}$.

Aunado a lo anterior, el tratado de Huarte se basa en la República de Platón, por lo que tiene como propósito ayudar al reino a tener "hombres hábiles" a través de la distinción temprana de los ingenios y su correcta aplicación en la ciencia que le corresponda, según su naturaleza, siempre en

${ }^{62}$ Id., pp. 193-194.

${ }^{63}$ Vid. id., pp. 194-203. Da una distinción de ingenio similar en el capítulo I de la edición de 1575 (III en la de 1594), vid.id., p. 230.

64 "La gente vulgar, en viendo a un hombre de grande ingenio y habilidad, luego señala a Dios por autor y no cura de otra causa ninguna, antes tiene por vana imaginación todo lo que discrepa de aquí. Pero los filósofos naturales burlan de esta manera de hablar; porque, puesto caso que es piadosa y contiene en sí religión de verdad, nace de ignorar el orden y concierto que puso Dios en las cosas naturales el día que las crió'” (id., pp. 234-235).

65 Vid. id., pp. 203-206.

66 "De la buena imaginativa nacen todas las artes y ciencia que consisten en figura, correspondencia, armonía y proporción. Estas son: poesía, elocuencia, música, saber predicar, la práctica de la medicina, matemáticas, astrología, gobernar una república, el arte militar; pintar, trazar, escrebir, leer, ser un hombre gracioso, apodador, polido, agudo in ailibus, y todos los ingenios y maquinamientos que fingen los artífices; y también una gracia de la cual se admira el vulgo, que es dictar a cuatro escribientes juntos materias diversas, y salir todas muy bien ordenadas" (id., pp. 395-396). Cabe destacar que aquí Huarte está considerando bajo la misma cualidad a los individuos agudos.

${ }^{67}$ Felice Gambin, "Menosprecio de la literatura y alabanza de filosofía: Huarte de San Juan y la imaginación vigilada", en Christoph Strosetzki (ed.), Actas del V Congreso de la Asociación Internacional Siglo de Oro, p. 608, disponible en línea por Centro Virtual Cervantes: https://cvc.cervantes.es/literatura/aiso/pdf/05/aiso_5_060.pdf. Sobre las tres cualidades que controlan el temperamento y crean los distinto tipos de ingenios $c f$. J. Huarte de San Juan, op. cit., pp. 321-346.

${ }^{68} I d .$, p. 285.

69 "En el catálogo de las ciencias que pertenecen a la imaginativa pusimos al principio la poesía, y no acaso con falta de consideración, sino para dar a entender cuán lejos están del entendimiento los que tienen mucha vena para metrificar" (id., p. 403). 
miras de "las necesidades políticas" ". De hecho, parece que Huarte contrapone el ingenium excellens cum mania al ingenio caprichoso, que es también inventivo, pero no está destemplado:

A los ingenios inventivos llaman en lengua toscana caprichosos, por semejanza que tiene con la cabra en el andar y pacer. Esta jamás huelga por lo llano; siempre es amiga de andar a sus solas por los riscos y alturas, y asomarse a grandes profundidades; por donde no sigue vereda ninguna ni quiere caminar con compaña. Tal propriedad como ésta se halla en el ánima racional cuando tiene un celebro bien organizado y templado: jamás huelga en ninguna contemplación, todo es andar inquieta buscando cosas nuevas que saber y entender. ${ }^{71}$

En concordancia con los filósofos antiguos y aceptando que todo proviene de la Naturaleza ${ }^{72}$, el médico pretende dar una explicación racional y empírica que explique, precisamente, "qué cosa sea Naturaleza"73 y todo lo que esta ha ordenado. Así, la relación que el Tesoro establecía entre ingenio y agudeza/sutileza se explica en Examen de ingenios de forma prácticamente fisiológica.

El capítulo III de la edición de 1575 (VI en la de 1594) es "Donde se declara qué parte del cuerpo ha de estar bien templada para que el muchacho tenga habilidad" y Huarte lo hace a partir de los cuatro ventrículos del cerebro, que deben encontrarse en condiciones para que el ánima racional discurra y filosofe ${ }^{74}$. Entre estas condiciones, quiero resaltar la cuarta que enuncia que el individuo debe

tener el celebro la sustancia o compostura de partes sutiles y muy delicadas, dice Galeno que es la más importante de todas; porque, quiriendo dar indicio de la buena compostura del celebro, dice que el ingenio sutil es señal que el celebro está hecho de partes sutiles y muy delicadas, y si el entendimiento es tardo arguye gruesa sustancia; y no hace mención del temperamento. ${ }^{75}$

La sutileza del ingenio es para Huarte, médico de profesión, el resultado de que el cerebro es fisiológicamente sutil. No hay de por medio inspiración y si la hay es porque el cerebro está destemplado a causa del calor, lo que, sin embargo, no puede ser bueno para el "hombre útil".

En suma, Examen de ingenios para las ciencias nos presenta el ingenio desde una visión fisiológica, dependiente de cualidades como el calor, la humedad y la sequedad, que lo modifican y crean los diferentes tipos de ingenios. Pero también establece el papel esencial del ingenio como parte del entendimiento creador de conocimiento. Es pues el ingenio capacidad natural sin la cual el ánima racional no puede hacer sus digresiones.

${ }^{70}$ G. Serés, op. cit., pp. 27. Además, vid. id., pp. 26-42, así como el "Proemio a la Majestad del rey don Filipe, nuestro señor", J. Huarte de San Juan, op. cit., pp. 149-156.

${ }^{71} I d$., pp. 344-345.

72 “Sentencia es muy común y usada de los filósofos antiguos diciendo: 'Naturaleza es la que hace al hombre hábil para aprender, y el arte con sus preceptos y reglas le facilita, y el uso y experiencia que tiene de las cosas particulares le hace poderoso para obrar"' (id., p. 234).

${ }^{73}$ Loc. cit.

${ }^{74}$ Vid. id., pp. 279-286.

${ }^{75}$ Id., p. 285. 
Como colofón a esta introducción, hay algunos aspectos que me gustaría rescatar para el desarrollo de la investigación subsecuente, pues son puntos claves para la revisión de ambos términos en el corpŭs.

1) El término agudeza -no siempre presente como sustantivo- puede estar asociado por sinonimia a sutileza -en ocasiones también a delicadeza- y por traslación a ingenio, tal y como lo reportan los diccionarios y Huarte.

2) Lo anterior señala el potencial metafórico del término agudeza, lo cual es fundamental para las poéticas del corpŭs.

3) Desde las poéticas de Aristóteles y Horacio ya se contemplan diferentes tipos de ingenio. Esto es desarrollado con mayor profundidad en la obra de Huarte y, como puede suponerse, está también presente en las poéticas.

4) Siguiendo las consideraciones platónicas y aristotélicas existe un importante punto de unión entre furor poético e ingenio, cuya relación es primordial para conocer las denotaciones particulares del segundo en mi corpŭs.

5) El Examen de ingenios ofrece una explicación fisiológica de ingenio, además de anotar su relación con el entendimiento y la imaginativa.

6) La relación ingenio-naturaleza y su contraposición con el arte es esencial en la formación del binomio horaciano arte-ingenio, que permea la reflexión poética de los siglos XVI y XVII en España.

Estos seis puntos, como he insistido, marcan la tradición de las reflexiones y creaciones poéticas de los Siglos de Oro. Por lo tanto, ofrecen una guía de lectura que facilita la comprensión de la denotación y connotaciones que tiene ambos términos, agudeza e ingenio, en las poéticas del presente trabajo. Ahora bien, creo importante señalar que el objetivo de este análisis responde a la carencia de trabajos que observen la presencia de agudeza e ingenio en las poéticas previas a Agudeza y arte de ingenio $^{76}$.

Quiero agregar que el corpŭs se ha escogido con base en las particularidades de las cinco poéticas, las cuales responden de diferente manera a la práctica poética de su época, como se observa, por ejemplo, en la importancia que dan al ingenio o al arte. De esta forma, recupero reflexiones en

\footnotetext{
${ }^{76}$ Se vean como casos ejemplares los citados trabajos de Mercedes Blanco (Les Rhétoriques de la Pointe) y García Berrio (Formación de la teoría literaria moderna, 2 tomos). La primera se centra en los términos a partir de los tratados del español Baltasar Gracián y de los italianos Peregrini, Pallavicino y Tesauro. Por su parte, el segundo centra su digresión en las poéticas latinas e italianas del Renacimiento italiano para pasar a la teoría literaria del siglo XVII, aunque siempre a partir de los principios horacianos, por lo que trata parcialmente el ingenio. Por supuesto, se encuentran también las tesis doctorales de Férnandez-Corugedo y Rodríguez Beltrán, las cuales me ayudaron a comprender mejor la tradición de ambos términos. No obstante, el primero analiza someramente solo tres de las poéticas del corpŭs y las relaciona siempre con Gracián. El segundo, por su parte, analiza la "metáfora de la punta" en las retóricas españolas renacentistas.
} 
torno a agudeza e ingenio desde posturas apegadas a la tradición clásica e italianas o bien más moderadas o cercanas al fenómeno poético. Es decir, con el corpŭs pretendo cubrir diferentes opiniones presentes en los Siglos de Oro.

Para cumplir cabalmente con los objetivos de mi análisis, en el "Capítulo I" expongo en primer lugar un estado de la cuestión sobre la crítica de estas poéticas. Más adelante, recupero características importantes del ambiente cultural que determinó la producción, elaboración y transmisión del corpŭs, para identificar el humus que compartían entre sí y con la producción poética del momento. Asimismo, lo anterior permite describir y comprender mejor las generalidades de las poéticas, haciendo hincapié en sus propósitos y metodologías. Establezco en consecuencia convergencias y divergencias, que me permiten dividir los cinco textos en poéticas dialógicas -Philosophia, Cisne y Tablas- y discursivas - “Libro" y Discvrso-, lo que explica que el orden del análisis no sea totalmente cronológico.

Dedico dos capítulos al análisis del corpŭs. El "Capítulo II" se centra en la agudeza y el “Capítulo III" en el ingenio. Cada uno de ellos está dividido en dos partes que corresponden a la división de las poéticas explicada en el "Capítulo I". Así, presento primero las poéticas dialógicas y posteriormente las discursivas. Al final del apartado de cada texto, hago una pequeña síntesis de los resultados obtenidos.

Asimismo, en los respectivos análisis informo cuántas veces aparece cada término y comento caso por caso. En consecuencia, aíslo los términos a tratar, así como sus posibles sinónimos y los pongo en contexto con los fragmentos que los contienen. En este primer momento del análisis, señalo la función gramatical y los adjetivos que los acompañan. Luego, anoto si se está denotando o connotando agudeza o ingenio a partir de metáforas, lugares comunes, etc.

La revisión de cada caso me permite relacionar los fragmentos con el resto del texto para develar la importancia que agudeza o ingenio tienen para la fundamentación de la poética. Por otro lado, a la par de esta labor, tomo en cuenta las anotaciones que diferentes críticos han hecho sobre la presencia de estos términos en las poéticas, aunque, como he advertido, no ha existido un especial interés al respecto en este corpŭs. Sin embargo, el invaluable trabajo de las ediciones modernas ${ }^{77}$ me ha permitido conocer las auctoritates de los humanistas y poetas, a las que hago constante alusión, pues el eclecticismo es determinante en las reflexiones del corpŭs.

Finalmente, a partir de la síntesis de los apartados, realizo las "Conclusiones" en donde es notable que no existe una definición única y cristalizada de los términos que me ocupan. Existe más bien una serie de connotaciones que demuestran tanto la riqueza de los conceptos como de las

\footnotetext{
${ }^{77}$ Como comenté en la "Advertencia”, con excepción de la poética de López Pinciano, el resto del corpŭs posee ediciones comentadas o anotadas de la segunda mitad del siglo XX e inicios del XXI.
} 
reflexiones de los humanistas y poetas españoles. Procuro, empero, señalar los puntos de convergencia y divergencia para demostrar que parten de una misma tradición y, aún así, cada autor se apropia de esta y la particulariza. 


\title{
CAPÍTULO I
}

\author{
CINCO POÉTICAS ESPAÑOLAS DE LA SEGUNDA MITAD DEL SIGLO XVI Y PRINCIPIOS \\ DEL XVII
}

\section{LA CRÍTICA EN TORNO A LAS POÉTICAS ESPAÑOLAS DE FINALES DEL SIGLO XVI Y PRINCIPIOS DEL XVII:} NOTAS SOBRE UN PREJUICIO

En 1985, Aurora Egido recuperó de la Philosophia antigva poetica de Alonso López Pinciano la cita "sin Poeticas ay Poetas" (f. 496) para ilustrar el resultado del rastreo de la teoría de la égloga en el Siglo de $\mathrm{Oro}^{78}$. Un cuarto de siglo después, José Manuel Rico García hizo un quiasmo con la misma frase: "Sin poetas hay poéticas"79. Dicha peculiaridad es un resabio de un lugar común dentro de la crítica literaria: el carácter desligado que tenía la preceptiva de la segunda mitad del siglo XVI y principios del XVII con respecto a la producción poética.

La opinión común debe mucho a Antonio Vilanova -uno de los primeros estudiosos en "rescatar" un corpŭs de estudio tan abandonado-, quien ya había afirmado a mediados del siglo XX que los poetas del petrarquismo español eran "unos improvisadores geniales que proceden a la adaptación puramente empírica de los metros y formas italianas" ${ }^{\$ 0}$. De forma similar lo consideró Begoña López Bueno con la lírica que fue descuidada por los humanistas a causa, según la estudiosa, del culto especial que estos guardaban hacia el mundo clásico ${ }^{81}$. Por otra parte, Federico Sánchez

78 "Sin poética hay poetas. Sobre la teoría de la égloga en el Siglo de Oro”, Criticón, 30 (1985), pp. 43-77. La cita de Pinciano es también recordada por Marcelo Rioseco: "Según Rafael Lapesa: 'los códigos de los preceptistas eran constantemente desmentidos por la realidad: unos géneros caían en el olvido, nacían otros nuevos, y los subsistentes experimentaban incesantes variaciones, en suma, lo que con certero laconismo formuló el Pinciano: sin poéticas había poetas"” ("Jáuregui y la censura a la poesía nueva", Espéculo. Revista de estudios literarios. Universidad Complutense de Madrid, 34, 2006, s. p., n. 22; disponible en línea: https://webs.ucm.es/info/especulo/numero34/jauregui.html). El crítico remite a su vez al texto de Rafael Lapesa Melgar (Introducción a los estudios literarios, pp. 123-124). Sin embargo, desconozco si a causa de un error por parte de Rioseco al momento de cerrar la cita o por la edición de consulta del libro de Lapesa-Rioseco cita la primera edición de 1979, mientras para este trabajo consulté la vigésimo tercera de 2008- este no cita a Pinciano, y su texto termina justo en "incesantes variaciones" (vid. loc. cit.). Pese a tal errata, el principio del vallisoletano se mantiene y representa para gran parte de la crítica la fragilidad y lo efímero de las preceptivas frente a los fenómenos artísticos.

79 “'Sin poetas hay poéticas': los tratados de preceptiva literaria y el canon en el siglo XVII”, en Begoña López Bueno (coord.), El canon poético en el siglo XVII. IX Encuentro internacional sobre Poesía del Siglo de Oro, pp. 93-123. 80 “Preceptistas españoles de los siglos XVI y XVII", en Guillermo Díaz-Plaja (dir.), Historia general de las literaturas hispánicas, III, Renacimiento y Barroco, pp. 567-568.

${ }^{81}$ Para la hispanista, "en la teoría poética del Siglo de Oro, y particularmente en la referida a la poesía lírica, se pagó un alto precio por la veneración de lo antiguo: el correspondiente a la enorme desconexión con la literatura de su tiempo" ("Las retóricas españolas en el siglo XVI: un canon al margen", en B. López Bueno (ed.), El canon poético en el siglo XVI..., p. 49). Debo aclarar que López Bueno se refiere específicamente a las retóricas del siglo XVI, a las cuales como ya desde el título de su trabajo se anticipa-considera sin injerencia real en la creación poética: "Diré desde ahora, sin embargo, que el grado de interferencia o, por mejor decir, el grado de eficacia práctica de las retóricas en la gestación del texto literario es más que discutible" (id., p. 47). Asimismo, Juan Manuel Daza Somoano y Jaime Galbarro García, pertenecientes como López Bueno al Grupo PASO, afirman que las retóricas son más o menos tangenciales a la literatura (vid. "Hacia una catalogación de las más importantes retóricas españolas del siglo XVI. Tradiciones, modelos y tendencias", en id., p. 75). 
Escribano tuvo una opinión cercana, pero matizada, con respecto al teatro ${ }^{82}$ y por supuesto Egido con la producción poética en general ${ }^{83}$. Las razones que provocaron que la preceptiva se escribiera a espaldas de la producción poética obedece -sintetizando los diferentes pareceres de la crítica- a tres aspectos principales. Estos, en mayor o menor medida, han provocado que las poéticas hayan sido estudiadas superficialmente o con cierto desdén.

\section{El carácter tardío de las primeras poéticas españolas}

El primer aspecto responde a la aparición de las poéticas españolas cuando la poesía española ya había alcanzado su madurez con Garcilaso de la Vega, después de un complejo proceso de experimentación y apropiación de los modelos italianos. De hecho, la mayor parte de la crítica justifica el desarrollo de la poesía española únicamente a través de la imitación de los modelos italianos: un aprendizaje meramente empírico -la "poética empírica" de Egido-, cristalizado en los “improvisadores geniales” de Vilanova. Sin embargo, López Bueno pone en duda que haya sido la única fuente de inspiración poética para los petrarquistas hispanos, pues es innegable que contaban también con los textos teóricos de los comentaristas italianos ${ }^{84}$, con los que seguramente tuvo contacto, por ejemplo, Garcilaso durante su viaje a la península itálica.

Tal hipótesis, pese a todo, ya había sido también puesta en evidencia por el mismo Vilanova, quien afirma:

los escasos poetas españoles que alcanzan un sólido conocimiento de la versificación italiana, suplen la ausencia de preceptivas castellanas con el estudio de las leyes y preceptos métricos de Antonio da Tempo en su comentario al Canzoniere de Petrarca; de Giangiorgio Trissino en sus Divisioni della Poetica (1529); de Claudio Tolomei en sus Versi e regole della nuova poesia toscana (1539); de Bernardino Daniello en su Poetica volgare (1536); de Girolamo Muzio en su Arte Poetica (1551); y, sobre todo, de Girolamo Ruscelli en su Modo di comporre in Versi nella lingua italiana (1559). ${ }^{85}$

Pese a la muy probable injerencia de la teoría italiana en los poetas españoles, el terreno de la práctica iba un paso adelante del de la teoría. Así lo argumenta sistemáticamente Aurora Egido a lo largo de su ensayo "La hydra bocal, sobre la palabra poética en el Barroco", donde considera que Agudeza y

${ }^{82}$ Vid. Federico Sánchez Escribano, "Algunas observaciones introductivas a la teoría dramática de los siglos XVI y XVII", en F. Sánchez Escribano y Alberto Porqueras Mayo (eds.), Preceptiva dramática española. Del Renacimiento y el Barroco, p. 50.

${ }^{83}$ Aurora Egido afirma que "la práctica literaria impuso una poética empírica, que los autores aceptaron o desarrollaron con la libertad que presta el uso de lo implícito frente a la inexistente autoridad de normas establecidas" (A. Egido, op. cit., p. 46). Así lo reafirma más adelante al observar los elementos aristotélicos presentes en La Galatea de Cervantes. Egido contradice a Riley, para quien Cervantes había efectivamente leído la preceptiva neoaristotélica, y concluye que "la propia evolución del género le llevaba a planteamientos muy cercanos a los de la Poética de Aristóteles. Eran ideas que se filtraban por la propia vía creativa y ambiental, al margen de las preceptivas" (id., p. 59, n. 28).

${ }^{84}$ Vid. "Poesía, poética y retórica en el Siglo de Oro español: la teoría frente al Espejo", en Natalia Fernández Rodríguez y María Fernández Ferreiro (coords.), Literatura Medieval y Renacentista en España: líneas y pautas, p. 97.

${ }^{85}$ Op. cit., p. 568. 
arte de ingenio es la única poética barroca válida, porque esta solo puede surgir "a posteriori, cuando ya la poesía, salvo raras excepciones, camina a su declive y Gracián reflexiona, condensa, antóloga y ordena un texto que va a funcionar más como el testamento poético de su tiempo que como formulario de preceptos al servicio de poetas futuros". Entonces, antes de Gracián, agrega, la "nueva preceptiva y la nueva retórica habían surgido no de Pinciano ni de Carvallo, Jiménez Patón o Cascales, sino de Góngora, Quevedo y Lope, entre otros" ${ }^{\prime 6}$.

La postura de Egido se sustenta con lo ocurrido en los Siglos de Oro, pero también con un fenómeno particular de la teorización poética, la cual generalmente es tardía respecto al proceso que analiza y sintetiza: la poesía. Como ejemplo, baste ver la Poética de Aristóteles, que fue realizada durante la decadencia de la tragedia griega. Sin embargo, este no es el espacio para ahondar en el tema, sino enfatizar cómo la crítica, por medio de estos postulados, ha relegado el estudio de las poéticas de los siglos XVI y XVII a un ámbito más bien documental y secundario, en la mayoría de los casos.

Ahora bien, no se puede negar que las poéticas fueron a posteriori de la producción poética, lo que explica, entre otras cosas, la brevedad de su presencia en la península ibérica. En 1580 aparece la primera poética española por la pluma de Miguel Sánchez de Lima, El arte poetica en romance Castellano. El año es parteaguas en la tradición española, además, por otro resultado sistemático ${ }^{87}$ de teoría poética: las Obras de Garci Lasso dela Vega con anotaciones de Fernando de Herrera. El trabajo del sevillano son comentarios que a causa de su profundidad, reflexión y erudición superan no solo los impresos seis años antes por Francisco Sánchez de las Brozas, sino también y, por mucho, la breve poética de Sánchez de Lima, más centrada en el aspecto métrico.

Asimismo, las Anotaciones son vistas como un estudio más cercano al fenómeno poético que cualquiera de las poéticas que se hicieron por su propio carácter de comentario $^{88}$. La diferencia abismal en cuanto a la calidad de contenido entre ambas obras señala el inicio de un marco que la crítica desde el siglo XVIII fue construyendo en torno a la poética española y que ya he ido anunciando: su carencia de valor en la producción poética.

De lo anterior da cuenta Ignacio de Luzán -el primer gran crítico de las poéticas que precedieron su trabajo-, quien hace uso, irónicamente, de un lugar común de las primeras poéticas

${ }^{86}$ Edad de oro, VI (1987), p. 82.

87 “Insisto en lo de 'sistemáticas', esto es, elaboradas en tratados integri sobre teoría y preceptiva, ya en la forma más convencional de las llamadas Poéticas o en la menos reglamentada, pero generalmente más eficaz, de los Comentarios o Anotaciones a autores, puesto que textos sobre ideas poéticas abundan a lo largo del siglo XVI, ya sean de carácter profano o religioso, principalmente en los llamados paratextos, esto es, preliminares o, más raramente, postliminares, de los libros" (B. López Bueno, "Poesía, poética y retórica...", p. 97).

88 "Sólo las Anotaciones a Garcilaso, 1580, de Fernando de Herrera, que no son ni una poética (pero la contienen), ni una retórica (pero la contienen) están en permanente relación dialéctica con los textos: no en balde son unos comentarios" (B. López Bueno, "Las retóricas españolas...”, p. 73). 
del siglo XVI. En las primeras páginas de La poetica, Luzán afirma que faltan "tratados de Poetica [...], y tan doctas Criticas, tan ingeniosas Apologìas"89 como los que existían en Italia y Francia, así como la carencia de calidad de las pocas que existen. Aunado a esto:

Solo en España por no se què culpable descuido mui pocos se han aplicado à delucidar los preceptos poeticos, y tan remisamente, que (por quanto yo sepa) no se puede decir que tengamos un cabal, y perfecto tratado de Poetica. Querer atribuir esta falta à la de ingenio, y erudicion, seria desvarìo; pues dexando aparte otras muchas razones, quien duda, que tantos excelentes Poetas Españoles, que escribieron con singular acierto en la practica, no ignoraban la theorica. Por ventura, si Garcilaso, ò Camoes, ò Lupercio, ò Bartolmé Leonardo, ò Herrera, ò algun otro de los muchos que han adquirido fama inmortal con sus versos, hubieran dado à la enseñanza, y explicacion de las reglas una parte de las fatigas que les costaba su execucion; no tendriamos aora un numero copioso de tratados perfectos con que arreglar nuestras Poesias? ${ }^{90}$

El lamento de Luzán no es aislado. El mismo Vilanova, a poco más de dos siglos de distancia, lamenta la carencia de una poética escrita por Herrera o el Brocense ${ }^{91}$ y Karl Kohut -quien intenta demostrar sin mucho éxito la existencia de una teoría poética anterior a 1580- asevera de forma cuestionable: “Otros planes de poéticas (si bien posteriores a 1580) los tenemos en Herrera y Bravo. Todas estas obras parecen haberse perdido" $"$.

La búsqueda de Kohut se centra en documentos que prueben la existencia de reflexiones estéticas en torno a la poesía en España antes de 1580, o incluso antes de 1517 -fecha basada en el texto de Torres Naharro, Propalladia ${ }^{93}$. De tal guisa, demostraría constancia en la producción de teoría poética en la península ibérica para describir una evolución de la preceptiva nacional. Ahora bien, el trabajo del estudioso podría hacer pensar que el principal problema de esta preceptiva sea la cantidad de testimonios que existen o, precisamente, de lo tardío de su formulación. Sin embargo, no

${ }^{89}$ La poetica, ó reglas de la poesia en general, y de svs principales especies, p. 3 (disponible en línea: https://books.googleusercontent.com/books/content?req=AKW5QafbsnHUB6zCFXi11k0tLturQjdJTX51WKiK1PX8e5 5mkMBm7tRx15dCtT4WekMlQy15iwTxpmrIzoBd21NR5-

1B6Bvhj_xm7rjt7yhM9dOEjgZFxC9BzZW6pXMi7DrDDKiKyZ6FgCOUzyFNdrio513_Mzyq8OIlLmmbC8OiiSzeL9u st4QrK8LSQHlaEUaZbWyBronT5yNfyjODq5Od2hnM9iPtbi68uKO3ACqP0-Xn0txDKR9fxLw0N0U52PiWGRxIV1Z9koBZSb2iz7-5sxyaj1XgQ).

${ }^{90} I d .$, pp. 3-4.

${ }^{91}$ Vid. op. cit., p. 569.

92 Las teorías literarias en España y Portugal durante los siglos XV y XVI. Estado de la investigación y problemática, p. 16. Al hablar de las poéticas precedentes a las Tablas poeticas de Cascales, Antonio García Berrio corrobora la brevedad de las poéticas en España, ante la falta de las mismas pruebas que Kohut esperaba algún día encontrar: "Las iniciativas para ampliarlo, adelantando sus orígenes hacia comienzos del siglo XVI, pese al confiado entusiasmo que atestigua Karl Kohut, no han cristalizado hasta el momento en el descubrimiento de hallazgos anteriores a 1580, fecha de la publicación simultánea de los Comentarios a Garcilaso, de Fernando de Herrera, y de El arte poética, de Miguel Sánchez de Lima. Los trabajos españoles en Poética de Alejo de Vengas, Bartolomé Bravo, e incluso el propio Herrera, no han sido sacados todavía a la luz por nadie, muy probablemente porque nunca la vieron originalmente; quedándose en bosquejos, proyectos y promesas de sus autores o de sus amigos" (Introducción a la poética clasicista. (Comentario a las Tablas Poéticas de Cascales), pp. 31-32).

${ }^{93}$ Vid. K. Kohut, op. cti., p. 5. La apología de Kohut es una respuesta a textos como el de Sanford Shepartd que para establecer los antecedentes antes del Pinciano se remite a la poética trovadoresca, deteniéndose en el Arte de poesía castellana de Juan de Encina, dejando un importante vacío entre esta y la Philosophia del médico de Valladolid (vid. Sanford Shepard, El Pinciano y las teorías literarias del Siglo de Oro, pp. 11-21). 
es así. La crítica ha observado lo poco aptas que las poéticas eran para la poesía de la época, ya perceptible en la notable distancia entre Herrera y Sánchez de Lima. Además, pese a que esta disminuyó abismalmente con la Philosophia antigva poetica publicada por Pinciano dieciséis años después, las poéticas en general no dejaron de ser criticadas por lo que durante mucho tiempo se ha considerado su poca originalidad y su dependencia de la preceptiva italiana.

\section{El plagio de las primeras poéticas españolas}

El segundo aspecto y el más importante reproche de la crítica a las poéticas españolas es su carencia de "originalidad". Nuevamente Luzán es el primero que ya echa en cara el excesivo servilismo de obras como la de Cascales y Gonzáles de Salas hacia la Poética de Aristóteles -principalmente en lo que respecta al primero ${ }^{94}$ - y a toda la tradición de preceptistas italianos que más que inspirar a los españoles, fueron literalmente traducidos. De tal manera, Luzán justifica callar, casi totalmente, la voz de todas las poéticas españolas que lo precedieron para ceñirse directamente a los textos italianos.

La acusación no es menor y provocó que Marcelino Menéndez Pelayo -el primer crítico en rescatar y comentar, si bien no siempre de forma afortunada, un patrimonio ingente de teoría estética española ${ }^{95}$ - abogara por Cascales, y por los preceptistas españoles en general. Razón por la cual probablemente no hace un especial hincapié en lo inconexo entre teoría y producción artística después del trabajo de Rengifo ${ }^{96}$, evitando así restar importancia a las poéticas. En consecuencia, escribe Menéndez Pelayo a propósito de la crítica de Luzán:

Luzán, que no anduvo justo con ninguno de nuestros antiguos preceptistas, como si hubiera querido eclipsar su fama y borrar su recuerdo, dice desdeñosamente de Cascales que tomó mucho de Minturno y Robortello. Lo que Cascales trasladó de estos autores, citándolos siempre, no vale, ni con mucho, lo que él puso de su propia Minerva, y de fijo abulta menos que los párrafos y capítulos enteros que Luzán debe a Muratori y a Gravina. ${ }^{97}$

${ }^{94}$ Vid. op. cit., pp. 6-7.

95 "Saintsbury, en su History of Criticism and Literary Taste in Europe tuvo que reconocer que España tenía en la Historia de las ideas estéticas, de Menéndez Pelayo, quizá la mejor historia de la crítica literaria de ningún país europeo. Aún hoy día, todo el que quiera estudiar las teorías estéticas en España tiene que recurrir a dicha obra, puesto que sigue siendo la más extensa y, en definitiva, la única exposición de la materia" (Margarete Newels, Los géneros dramáticos en las poéticas del siglo de oro, p. 11). A este comentario, me gustaría agregar que, sin demeritar todos los estudios recientes sobre o a partir de preceptivas en aras de subsanar los descuidos de la crítica pasada, el trabajo de Menéndez Pelayo sigue siendo una fuente indispensable, lo que de cierta forma nos dice mucho sobre las historias literarias o estéticas disponibles al momento de abordar la preceptiva de los Siglos de Oro. Tal hecho ya lo había señalado también Alberto Porqueras (vid. "La verdad poética en la Edad de Oro", Temas y formas de la literatura española, p. 101). Es más, baste confrontar el exhaustivo trabajo de Menéndez Pelayo con el siguiente gran apartado dedicado a la preceptiva de estos siglos hecho por Vilanova. Por supuesto, ambos textos tienen funciones y espacios diferentes, pero aun tomándolos en su justa medida, la diferencia entre ambos es considerable, lo que ejemplifica las observaciones de Saintsubury y Newels.

${ }^{96}$ El juicio de Menéndez Pelayo sobre Rengifo ejemplifica claramente la situación desafortunada en la que se encuentra una poética acusada de ser una mera traducción (vid. Marcelino Menéndez Pelayo, Historia de las ideas estéticas en España. II. Siglos XVI y XVII, pp. 215-216).

${ }^{97}$ Id., p. 246. 
Menéndez Pelayo no carece de bases para criticar a Luzán con su mismo argumento y efectivamente Cascales en ocasiones deja sentado cuando es Robortello, Minturno u otra autoridad a quien está citando, parafraseando o comentando. No obstante, lo cierto es que la razón estaba más del lado del crítico de Zaragoza, tal y como lo corroboró primero su editor moderno Benito Brancaforte ${ }^{98}$ y luego su comentarista Antonio García Berrio, quien, además, lamenta profundamente toda la crítica escrita bajo el principio - tal vez arraigado desde la "reivindicación" hecha por Menéndez Pelayo- de que las ideas del murciano eran propias y no producto de traducciones de diferentes preceptivas italianas ${ }^{99}$.

García Berrio condena principalmente a Cascales porque incluso considerando el proceso creativo de la ı̌mítātı̆o durante el Renacimiento y el uso de polianteas, florilegios u otros, opina que el murciano hace un "plagio literal" de las poéticas italianas ${ }^{100}$. Sin profundizar más por el momento, diré solo que, pese a las poderosas e irrefutables evidencias que García Berrio proporciona, me parece que utilizar el término "plagio" para una poética de principios del siglo XVII sigue siendo anacrónico, puesto que aún desconocemos el proceso creativo de este tipo de textos. Es más, el mismo hispanista señala la "absoluta impunidad científica" 101 con la que circulaban las Tablas y otras preceptivas como el "Arte nuevo de hazer comedias de este tiempo" de Lope de Vega. Por lo tanto, evidencia que estas traducciones literales - presentes en mayor o menor grado en las preceptivas de la época- son un indicio, a mi parecer sintomático, de qué era lo que en los Siglos de Oro se considera como 'propio' de una preceptiva, principalmente de las poéticas, lo cual está relacionado estrechamente con la imirtătı̆o ecléctica.

Entonces, aun si aceptamos la hipótesis de García Berrio sobre la "ignorancia colectiva de textos capitales" 102 , aspecto por demás cuestionable ante lo extraordinario que podría resultar la existencia de tal colectividad ${ }^{103}$, opino que más que un intento de plagiar -entendiéndolo en la manera

98 Comenta el editor de Cascales: "muchos pasajes de las Tablas poéticas no son más que una traducción, con frecuencia literal, de los autores mencionados por Luzán” (Benito Brancaforte, "Introducción” para Franciso Cascales, Tablas poéticas, B. Brancaforte ed., p. XII).

${ }^{99}$ García Berrio señala a críticos de la talla de Irene Behrens, Claudio Gillén y Gérard Genette, quienes dan el crédito de la tripartición de los géneros literarios a Cascales, cuando este no hacía más que tomarlo de Minturno (vid. op. cit., pp. 25-29).

100 "Si destacamos como característica definitiva la falta de originalidad, es porque hemos podido constatar que las Tablas poéticas son en la inmensa mayoría de su extensión, y positivamente en todas las doctrinas que en ellas se suelen ponderar como fundamentales, un plagio literal de tres de los más difundidos tratados italianos de Poética: el Comentario de Robortello a la Poética de Aristóteles; la redacción italiana, L'arte poetica de Sebastiano Minturno, cuya obra quizá más difundida fue la latina De poeta; y los Discorsi dell'arte poetica de Torquato Tasso, redacción de difusión también muy inferior al desarrollo definitivo de sus ideas, más conocido en España, en los Discorsi del poema eroico" (id., p. 17).

101 Id., p. 23.

102 Loc. cit.

103 Vilanova ya había hablado sobre el número limitado de eruditos que pudiesen equiparse a la figura del Brocense o, aún más, de Herrera (vid. op. cit., p. 596), y, no obstante, valoro que si bien gran parte del hipotético público que integraba los ámbitos en los que se distribuyeron estas poéticas -academias y cortes principalmente, como se verá más adelante- no tenía el grado de conocimientos que el tratadista, sí existían ingenios con el suficiente bagaje cultural 
en la que Marcial ${ }^{104}$ o Baldassar Castiglione ${ }^{105}$ lo hacían-, se trata más bien de una estrategia tanto individual como grupal. Así lo entendió, por ejemplo, Porqueras Mayo, quien, ante los "descuidos" de Carvallo, afirma: "se trata de una práctica común en los siglos XVI y XVII la de esconder el origen primario de la información. Es una técnica racimo o esponja con la que se aprovecha todas, o gran parte, de las citas utilizadas por un autor al ilustrar un tema"106.

Lo anterior se asemeja al mecanismo que Mercedes Blanco delimita dentro del sistema y campo literarios. Para la hispanista, "la estrategia sirve a la consecución de satisfacciones íntimas, de un placer del texto"y

también sirve por supuesto los intereses sociales del escritor. [...] Merece el nombre de estrategia en cuanto debe establecer una transacción entre exigencias dispares, de naturaleza e importancia relativa muy variable. El designio de escribir tal tipo de obra y el modo de llevarlo a cabo obedece a un raciocinio (sólo parcialmente consciente) fundado en los deseos del sujeto que escribe, y en la apreciación de los recursos intelectuales, técnicos y sociales de que dispone, recursos relativos naturalmente a los requisitos de un sistema literario. ${ }^{107}$

para señalar tal vez no todas, pero sí la mayor parte de las fuentes. Por dar un ejemplo, con base en los dos testimonios directos que contienen el "Libro de ervdicion poetica" de Luis Carrillo y Sotomayor (Obras, impresas en 1611 y 1613), se sabe que una mano ajena fue la que agregó algunas precisiones y citas en latín en la segunda impresión, las cuales no debió tener el manuscrito original, hoy perdido (vid. "Desta segvnda impression, al Letor", $M_{2}$, s. f.). Ahora bien, podría decirse que se trata de una artimaña del anónimo corrector para justificar la nueva impresión, como las editoras modernas de Carrillo suponen que ocurrió con la creación poética que integra Obras (vid. Rosa Navarro, "Introducción biográfica y crítica" para Luis Carrillo y Sotomayor, Obras, R. Navarro ed., p. 34; y Fiorenza Randelli Romano, "Introduzione" para Luis Carrillo y Sotomayor, Poesie. I. Sonetti, F. Randelli Romano trad. y ed., pp. 91-92). No obstante, a diferencia de lo que ocurre con la producción poética de Carrillo, el corrector de $M_{2}$ no habría tenido ningún motivo para mentir sobre esta segunda mano en el manuscrito del Libro, sino, simplemente, decir que el mismo Carrillo había hecho los ajustes pertinentes, lo que, además, le habría dado más crédito a su impresión. Por tanto, quien haya hecho las adiectiones tenía suficiente erudición para discernir entre la pluma de Carrillo y la de sus autoridades, con la precisión incluso de indicar autor, título y lugar de la obra en donde se encontraba (vid. $M_{2}$, f. 113v-114r).

104 Se vean los epigramas dedicados a Fidentino en el "Liber I" de Epigramas. Por citar solo un ejemplo, el epigrama 53 reza: "Vna est in nostris tua, Fidentine, libellis / pagina, sed certa domini signata figura, / quae tua traducit manifesto carmina furto. / Sic interpositus uillo contaminat uncto / urbica Lingonicus Tyrianthina bardocucullus, / sic Arretinae uiolant crystallina testae, / sic ubi multisona feruet sacer Atthide lucus, / improba Cecropias offendit pica querelas. / Indie non opus est nostris nec iudice libris: / stat contra dicitque tibi tua pagina: 'Fur es'." [Hay una única página tuya, Fidentino, colada en mis / libros, pero marcada con la indudable impronta de su autor, / que hace ridículos a tus versos por robo manifiesto. / Así la capa lingónica, puesta sobre la púrpura violácea / de la ciudad, la contamina con su lana grasienta, / así los pucheros de Arretio desdicen junto a copas de cristal, / así, cuando el negro cuervo anda errante por las orillas del / Caístro, hace el ridículo entre los cisnes de Leda, / así, cuando el bosque sagrado resuena con el variado canto del ruiseñor, / la impertinente urraca desafina ante los lamentos cecropios. / Mis libros no precisan un delator ni un juez: / tu página se alza contra ti para decirte: "Eres un ladrón”] (Marco Valero Marcial, Epigramas, I, (Libros 1-7), Enrique Montero Cartelle trad., pp. 36-37, vid. también los epigramas 29, 38 y 72). De hecho, Marcial fue el primer latino en emplear el término plagiarius para referirse al robo de sus obras, consideradas como sus propios hijos (vid. Helène Mauret-Indart, Sobre el plagio, pp. 21-22).

${ }^{105}$ Es bien sabido que una de las razones que llevó a Castiglione a la impresión de Il libro del Cortigiano en 1528 fue una indiscreción por parte de Vittoria dalla Collona, que provocó que el manuscrito corriera libremente en Pescara y fuera copiado indiscriminadamente. Por consiguiente, Castiglione temió que alguien más se hiciese pasar por el autor del libro y que además tergiversara su contenido, lo que habría podido conllevar serias consecuencias para el diplomático italiano, a causa de la fuerte tensión política que se estaba viviendo en la península (vid. Walter Barberis, “Baldassar Castiglione. Gli ultimi bagliro dell’Umanesmo”, en B. Castiglione, Il libro del Cortigiano, pp. V-XI).

106 "Introducción" para L. A. Carvallo, Cisne de Apolo, p. 21-22.

107 Mercedes Blanco, "Poéticas, retóricas y estudio crítico de la literatura", Bulletin Hispanique, t. 106, n. 1 (2004), p. 219 (disponible en línea: https://www.persee.fr/doc/hispa_0007-4640_2004_num_106_1_5189). 
Y agrega más adelante: “A la estrategia de cada individuo o grupo hay pues que sumar una estrategia del campo en su conjunto frente al resto de la sociedad" ${ }^{108}$. En este caso, me remito a un campo de eruditos en preceptiva italiana, latina y, en menor medida, griega, cuya estrategia consistía probablemente en apropiarse tanto de las fuentes clásicas como de las contemporáneas a ellos. Por tanto, opino que hace falta reconsiderar las estrategias usadas durante los Siglos de Oro por un grupo de hombres de letras, que tenían un humus intelectual en común, para la creación de las preceptivas en general y de las poéticas en particular. De tal forma, muchos de los prejuicios y reservas que incluso hoy se tienen entre los críticos sobre estas se disiparían.

\section{Servilismo de las poéticas ante la preceptiva italiana}

El tercer aspecto, consecuencia lógica de lo anterior, es la carencia de valor que las poéticas tardías españolas tenían al retomar únicamente de forma literal el contenido de la preceptiva italiana, ora en vulgar, ora en latín. De hecho, tal aspecto responde principal y satisfactoriamente la incógnita de García Berrio ante el tránsito impune de los "plagios literales". Afirma el crítico: "Ni nuestros tratadistas se sentían con fuerzas, al menos en materia de ideas estéticas, para avanzar sobre el estado de las cuestiones en Italia, ni mucho menos para discutir la autoridad de los italianos, considerados insuperables"109. Tal certidumbre se esbozaba ya desde Menéndez Pelayo, quien califica todos los comentarios y paratextos posteriores al Arte de Trobar de Juan de Enzina y anteriores a 1580 un mero esfuerzo filológico. De tal guisa, los españoles habrían tenido que esperar, según Menéndez Pelayo, la escuela de la preceptiva italiana para formular sus propias teorías y plasmarlas en poéticas, pese a que la escuela petrarquista ya había triunfado ${ }^{110}$.

La afirmación de García Berrio, por otro lado, solo hace eco de una idea persistente en la crítica: el hecho de que las poéticas españolas son un "recuelo de teorías italianas"111. Aquí, sin deseo de secundar tan tajante afirmación, es necesario agregar que además de las traducciones o paráfrasis, hay una visible carencia de referencias a poéticas españolas precedentes -si acaso de forma sucinta como el caso de Cascales que señala los "errores" de Pinciano. De la misma manera, hay una gran falta de alusiones a la producción poética española, al grado de difuminarse ante lo ingente de los ejemplos clásicos o italianos. El resultado de esta falta de injerencia de la poesía en las poéticas provoca que Vilanova, sin hacer énfasis en la transliteración literal de las fuentes de las poéticas -

${ }^{108}$ Id., p. 224.

${ }^{109}$ Op. cit., p. 23.

${ }^{110}$ Vid. M. Menéndez Pelayo, op. cit., p. 214.

${ }^{111}$ K. Kohut, op. cit., p. 1. La conclusión es tomada a partir de A History of Literary Criticism in the Reinaissance, de Joel Elias Spingarn. 
posiblemente por desconocerlo-, reproche a las primeras poéticas españolas su poca o nula intromisión en la práctica poética ${ }^{112}$.

Si bien Vilanova se refiere específicamente a las poéticas de Sánchez de Lima y Rengifo, la crítica antes del catedrático de Barcelona había llegado a niveles tales para negar la existencia de aporte alguno de España a la crítica literaria de Europa. De tal forma lo hizo George Saintsbury en $A$ History of Criticism ${ }^{113}$, fomentando el descuido de la crítica a las poéticas ${ }^{114}$. Resultado por demás injusto incluso para figuras como Rengifo, ya que Vilanova pareciera olvidar su importante papel dentro de la formación intelectual que tuvo durante el siglo XVII y XVIII, como informa Isabel Paraíso: "Rengifo configura una teoría versificatoria española que conocerá un gran éxito en su época y en los siglos siguientes, será libro de texto en los colegios de la Compañía de Jesús, y pasará a ser canónico en la enseñanza de nuestra Métrica"115. Debido entonces a la importancia que la Compañía tuvo en la educación y a su injerencia en eventos públicos, la Poética de Rengifo se colocó también como punto de referencia en las justas poéticas, al ser el "Vademécun de los jueces de las justas, y presumimos que de los poetas" $" 116$.

La posición de Paraíso, por supuesto, demuestra cómo con el correr de los años la crítica se ha distanciado en gran parte de los principios de la crítica romántica -tan perniciosa para las poéticas precisamente por su principio de originalidad-, y las poéticas españolas encuentran en trabajos como el de Vilanova una tentativa de redención ante la deuda que se tiene con estas -aunque solo sea con una parte del gran corpŭs. Y, aunque hubo un espacio considerable entre la historia de Díaz-Plaja y los siguientes trabajos a propósito de preceptivas, las últimas generaciones de críticos han conseguido poco a poco volver a poner estos escritos bajo una lupa, si bien no siempre amable, si exhaustiva. De tal suerte, Newels, Rico García y Angel García Galeano han argumentado y demostrado el valor intrínseco de las poéticas más allá de su carácter tardío o de su dependencia -plagiaria, diría García

112 "Sería totalmente erróneo suponer que un manual escolar, escrito con una mera finalidad didáctica para el uso de principiantes profanos, como el Arte Poética en Romance Castellano de Miguel Sánchez de Lima, publicado en fecha tan tardía como 1580, pudo ejercer el menor influjo en los círculos poéticos de la escuela salmantina, regidos por las figuras geniales del Brocense y de fray Luis de León, o de la escuela sevillana sede de humanistas egregios como Juan de Mal Lara o Diego Girón, y de brillantes poetas como el eruditísimo Fernando de Herrera. Sería igualmente absurdo imaginar que un manual de arte métrica como el Arte Poética Española de Juan Díaz Rengifo, publicado en 1592, y basado como autoridad máxima en el anacrónico comentario latino de Antonio de Tempo, pudo ejercer el menor influjo en la maestría técnica de los grandes poetas cultos del barroco, como Lope, Góngora o Quevedo, que en aquel entonces habían ya escrito una buena parte de su obra" (op. cit., pp. 569-570).

${ }^{113}$ Vid. K. Kohut, op. cit., p. 1.

${ }^{114}$ Además de Kohut, cuyo trabajo esencialmente es una lucha contra el desdén de la crítica por el estudio de las poéticas, Newels se lamenta del efecto pernicioso que las afirmaciones de Spingarn y Saintsbury provocaron en el estudio de la teoría dramática durante el Siglo de Oro, pues "debía de parecer ya desde un principio empresa estéril y de poca monta" (op. cit., p. 12).

115 "Fundación del canon métrico: el Arte Poética Española, de Juan Díaz Rengifo", en Isabel Paraíso (coord.), Retóricas y poéticas españolas (siglos XVI-XIX): L. de Granada, Rengifo, Artiga, Hermosilla, R. de Miguel, Milá y Fontanals, p. 48.

116 A. Egido, "Una introducción a la poesía y a las Academias Literarias del siglo XVII", Estudios humanísticos. Filología, 6 (1984), p. 18 (disponible en línea: https://dialnet.unirioja.es/servlet/articulo?codigo=104658). 
Berrio- de las preceptivas italianas. Los críticos han preferido abogar por el diálogo que las poéticas establecen entre teoría y fenómeno poético ${ }^{117}$ o por su función como creadoras del canon y de reflexión teórica ${ }^{118}$.

Ahora bien, si el trabajo de Newels corresponde a lo que Kohut considera el mayor impacto de las poéticas dentro de la crítica -el estudio por género ${ }^{119}$-, el de García Galeano, poco secundado, enfatiza el papel de las poéticas como continuadoras y reinterpretadoras de una tradición clásica, que conlleva la concepción de términos basilares como el de la ı̆mĭtāť̆o. Actualmente, por otra parte, existen interesantes trabajos que, pese al "sin Poeticas ay Poetas", han tratado de vincular algunos principios anunciados en las poéticas a la producción artística de los Siglos de Oro, aunque estos son más bien particulares, en tanto que tratan a un solo preceptista. Sin embargo, me inclino a creer que un trabajo como el de García Galeano puede contribuir de manera más orgánica y reflexiva a comprender el sistema literario de los Siglos de Oro.

Con base en lo anterior, expondré a continuación cualidades esenciales del humus cultural compartido. Revisaré además los hipotéticos públicos que pudieron haber tenido. De esta manera, se tendrá más clara la intención de unas poéticas que han parecido poco necesarias para la producción poética de los Siglos de Oro y que, sin embargo, siguen estando presentes.

\section{CONSIDERACIONES A PROPÓSITO DEL AMBIENTE CULTURAL Y LOS PÚBLICOS EN LOS SIGLOS XVI Y XVII}

Es innegable que para entender y descifrar las estrategias utilizadas en las poéticas españolas de los Siglos de Oro es necesario observar en primera instancia el ambiente cultural en el que se desarrollaron sus ideas. Este marcó la identidad de humanistas como Pinciano, Carvallo, Cascales, Carrillo y Jáuregui, y justificó tanto su producción teórica como los métodos con las cuales lo hacían. El humanismo español es un periodo peculiar que propició la formación de academias, así como la búsqueda del perfecto cortesano, la proliferación de artis y las discusiones poéticas. Por ello, concretiza una serie de condicionantes para la creación de determinados tipos de poéticas en un momento específico y que vale la pena revisar someramente.

\section{Humanismo español: la vulgarización de los clásicos y modernos}

La discusión sobre la existencia y calidad del humanismo que se vivió en España durante los siglos XV, XVI y XVII está presente desda la prometida -y nunca llevada a cabo- Historia del humanismo

${ }^{117}$ Vid. Newels, op. cit., p. 7.

118 Vid. J. M. Rico García, op. cit., p. 123.

${ }^{119} \mathrm{Vid}$. K. Kohut, op. cit., pp. 8-14, donde se da una amplia revisión de los diferentes trabajos que involucran a las poéticas para la teorización de un género y al que de cierta forma pertenece la comunicación citada de Egido ("Sin poética hay poetas. Sobre la teoría de la égloga en el Siglo de Oro"). 
español, que Menéndez Pelayo anunciaba en su "Advertencia a esta edición” de Horacio en España ${ }^{120}$, hasta el más reciente trabajo del filólogo español Javier García Gibert, La humanitas hispana. Sobre el humanismo literario en los Siglos de Oro ${ }^{121}$. Por supuesto, no se puede dejar de mencionar el aún hoy inigualable trabajo de Marcel Bataillon, Erasmo y España, que a través de figuras claves como la del cardenal Jiménez Cisneros, Antonio de Nebrija y Luis Vives expone la forma en la que la educación comenzó a cambiar a través de la creación de instituciones como, por ejemplo, la Universidad de Alcalá. Esta, si bien enfocada en la educación eclesiástica, inició la renovación teológica en España, dándole un giro que la acercaría de cierta manera a la formación humanista $^{122}$.

El cambio que realizó dicha universidad es de gran envergadura. Como indica el filósofo alemán Paul Oscar Kristeller, el humanismo -evitando todo el desgaste que dicho término ha tenido a lo largo de la historia de las ideas- era "más bien un programa cultural y educativo, en el cual se enfocaba y desarrollaba un campo de estudios importante pero limitado" ${ }^{123}$, concretizado en los studia humanitatis. Sin embargo, mientras en "el crepúsculo del Cuatrocientos, era inevitable en Italia una cierta depreciación del humanismo" 124 , como asegura Francisco Rico, en España el humanismo empezaba a adquirir una forma propia y nacional, después de un complejo proceso de asimilación. La tardanza de esta transición contribuyó a la creación de la "leyenda negra que propagaba por Europa la 'barbarie' moral y cultural española" ${ }^{125}$, que en realidad está relacionada con la realidad bélica vivida por España durante la Edad Media, como ya Fernando de Herrera ${ }^{126}$ argüía para justificar la tardanza de la poesía española en alcanzar los logros de la italiana. La tesis se sustenta con la

120 "Era mi propósito estudiar analíticamente la influencia del lírico latino en España, ya en sus traductores y comentadores, ya en las imitaciones directas ó indirectas. De esta manera debía ser trabajo preparatorio ó colección de materiales para un capítulo de la futura Historia del humanismo español, que siempre traigo en mientes, y á la cual no desespero de dar cima en un tiempo más ó menos largo, porque sería lástima que se perdiesen inéditos los copiosísimos datos que sobre esta materia, objeto querido de mis primeras aficiones literarias, tengo ya recogidos y en parte ordenados" (I, pp. IX-X). En 1980, Ana Martínez Arancón editó la Antología de humanistas españoles (Madrid, Editora Nacional), que intentó de cierta forma llenar esta carencia en la historia literaria española.

${ }^{121}$ Para un conciso y útil estado de la cuestión sobre la revaloración de la existencia del humanismo español, vid. La humanitas hispana. Sobre el humanismo literario en los Siglos de Oro, pp. 13-21.

${ }^{122}$ Vid. principalmente los dos primeros capítulos, "Cisneros y la prerreforma española" y "Primeros encuentros de Erasmo con España (1516-1520)", Erasmo y España, pp. 1-102.

${ }^{123}$ El pensamiento renacentista y sus fuentes, p. 40.

${ }^{124}$ El sueño del humanismo. (De Petrarca a Erasmo), p. 85.

125 J. García Gibert, op. cit., p. 14.

126 "pero [sic] los Españoles, ocupados en las armas con perpetua solicitud hasta acabar de restituir su reino a la religion Cristiana; no pudiendo entre aquel tumulto i rigor de hierro acudir a la quietud i sossiego destos estudios; quedaron por la mayor parte agenos de su noticia. i [sic] apena pueden dificilmente ilustrar las tinieblas de la oscuridad en que se hallaron por tan largo espacio de años" (Obras de Garci Lasso dela Vega con anotaciones de Herrera, f. 75; disponible en línea: http://www.cervantesvirtual.com/obra-visor/obras-de-garcilasso-de-la-vega--0/html/ff83d41a-82b111df-acc7-002185ce6064_77.htm). De forma velada, pero significativa, Carrillo y Sotomayor alude también a la necesidad de reposo que la poesía necesita ("Amigas son d[e]l ocio las Musas, y ellas madres del co[m]puesto hablar", $M_{l}$ f. $110 \mathrm{v}$ ), aspecto en el que ahondaré en su momento. 
importancia y fuerza que el tópico sapientia et fortitudo adquirió principalmente en España, tal como Curtius lo documenta ${ }^{127}$.

Con todo, en lugar de comparar el fenómeno español con el italiano, es importante señalar una de las principales particularidades del humanismo en la península ibérica. Me refiero a su carácter divulgativo, materialización de su orientación pragmático-sapiencial ${ }^{128}$, que conlleva una larga tradición. Sus orígenes se encuentran en la Escuela de traductores de Toledo -apoyada por Alfonso $\mathrm{X}$-, continúa con la vulgarización de textos eclesiásticos y filosóficos de Cisneros ${ }^{129}$ y con el programa de traducciones promovido por el Marqués de Santillana ${ }^{130}$. Así, concluye García Gibert:

la traslación al castellano de modelos y géneros escritos en latín por los humanistas europeos sería una constante en la prosa humanística española del siglo siguiente [XVI]: en su Diálogo por la dignidad del hombre, Pérez de Oliva recreará en castellano, en el primer tercio de la centuria, las reflexiones humanísticas que sobre este tema habían tratado en latín los italianos Facio, Manetti o Pico della Mirandola en la segunda mitad del siglo anterior; poco después, Pedro Mexía, en su Silva de varia lección, llevará a cabo en castellano su peculiar versión de las misceláneas latinas que proliferaban en la Europa humanista (Rodigino, Maffei de Volterra, Ravisio Téxtor, etc.); y Mal Lara en su Filosofía vulgar recoge y glosa la sabiduría humanística que se contiene en dichos y refranes castellanos, llevando a cabo en esta lengua lo que Erasmo en sus Adalgia había hecho en latín con sentencias griegas y latinas. ${ }^{131}$

En la enumeración hecha por el filólogo español cabe resaltar primero el carácter ecléctico de las vulgarizaciones, luego que estas no son de clásicos latinos o griegos, sino de italianos principalmente, mas no únicamente, $y$, finalmente, que no solo son refundiciones de otros textos, sino que pueden imitar un modelo, como los Adalgia de Erasmo. Todo esto permite comprender el carácter de vulgarización ecléctica presente en las preceptivas humanistas y, por supuesto, en las poéticas. Sin embargo, la mayor muestra de este "humanismo divulgativo" se hace presente en la comedia, principalmente durante la época del Fénix de los ingenios, como señalaré más adelante.

Por ahora, baste dejar claro que la vulgarización de textos clásicos e italianos es una estrategia que permeó diferentes áreas del saber y que constituye, más bien, una forma de organizar, interpretar y asimilar el conocimiento. En otras palabras, tal vulgarización ayuda a explicar el carácter "plagiario" de las poéticas pues forma parte de una estrategia intensificada con la nueva ola de textos clásicos (re)descubiertos y comentados por los filólogos italianos ${ }^{132}$. Asimismo, no se puede vincular el eclecticismo de la vulgarización o la transmisión de fuentes a un ámbito exclusivamente escrito, puesto que otros resultados del humanismo pudieron haber permitido el intercambio de reflexiones y

${ }^{127}$ Vid. Literatura europea y Edad Media latina, I, pp. 256-258.

${ }^{128}$ Vid. J. García Gibert, op. cit., p. 10.

${ }^{129}$ Vid. M. Bataillon, op. cit., pp. 48-51.

${ }^{130}$ Vid. J. García Gibert, op. cit., pp. 24, 30-34.

${ }^{131} I d$., p. 25.

${ }^{132}$ Ya decía Maurel-Indart: "En defensa de los ladrones, recordemos que la Antigüedad recién redescubierta en el siglo XVI se ofrece como presa de los escritores. Escribir es también traducir" (op. cit., p. 26). 
autoridades de forma oral. Así, primordialmente orales, las academias -y no solo-influyeron también en esta forma de organización y reflexión del saber.

\section{Los studia humanitatis y la academia}

Aunque huelga decirlo, los studia humanitatis convivieron con todas las áreas del saber, permitiendo que un médico como López Pinciano contase con la erudición necesaria para crear su Philosophia. El hecho ocurrió con la finalidad de que se compartiera una misma educación en los diferentes centros de enseñanza - en donde también imperaba la educación jesuita a través de la Ratio studiorum- y también porque el humanismo "se apoyaba en una impostación dialógica, exaltaba la amistad, la confianza, la reunión entre espíritus con idénticos propósitos y fines: los de la exaltación de la palabra, razón fundamental de la dignidad humana"133. Dichos espíritus son afines porque, en palabras de Rico, "se transfieren ciertos saberes de unos a otros y se sienten herederos de un mismo legado y, por polémicamente que a menudo sea, también vinculados entre sí" ${ }^{\prime 134}$. Todos estos elementos dan un carácter preponderante a la palabra, misma que permite a Pinciano ser heredero de Aristóteles o a Cascales de Minturno.

En suma, cualquier vínculo que se formara entre humanistas era a partir de la palabra $(\log o s)$, con la cual se materializaba físicamente el razonamiento humano. El individuo se separaba de los animales y de los ángeles, incapaces de transmitir sus pensamientos con el lenguaje ${ }^{135}$. De aquí que la palabra, primero hablada y luego escrita, tuviese el papel más importante dentro de esta red de humanistas deseosos de comunicar sus conocimientos, razonamientos y creaciones. La élŏcūť̆o se convierte entonces desde Luis Vives en punto de referencia y "hacia ella se encaminó el curriculum didáctico de los nuevos maestros que trataban de superar el mimetismo de la retórica tradicional"136.

Prueba de tal entusiasmo se refleja en la incorporación de las academias a la vida social. De estas se conservan importantes testimonios, pero a causa de su principio de oralidad no existe suficiente documentación para poder dar cuenta minuciosa de cada una de ellas, principalmente de las primeras en España ${ }^{137}$. Con todo, gracias a indicios o a los testimonios mencionados José Sánchez y Pasqual Mais i Usó realizaron importantes aportaciones que nos ayudan a comprender las dinámicas

${ }^{133}$ A. Egido, "Una introducción a la poesía...”, p. 9.

134 Op. cit., p. 13.

90.

${ }^{135}$ Vid. Esther Lacadena y Calero, “El discurso oral en las academias del Siglo de Oro”, Criticón, 41 (1988), p.

${ }^{136}$ A. Egido, "Literatura efímera: oralidad y escritura en los certámenes y academias de los Siglos de Oro", Edad de Oro, VII (1988), p. 70. Más adelante la investigadora agrega que en general "todos coinciden en hacer de la eloquentiae (gramática, retórica, filología) 'núcleo de toda la cultura', como presumían las Elegantiae de Valla. La salvación venía por la palabra, según predicaban los ciceronianos. Para nada servía la sabiduría callada” (id., p. 71).

${ }^{137}$ Vid. id., pp. 71-72 y Francisco J. Álvarez, Ignacio García Aguilar e Inmaculada Osuna, "Seventeenth-Century Academies in the City o Granada: A Comparatist Approach", en Arjan van Dixhoorn y Susie Speakman Sutch, The Reach of the Letters: Literary and Learned Societies in Late Meideval and Early Modern Europe, I, p. 10. 
de una institución heredada de Italia. Así, se sabe que, además de fomentar la oralidad a partir del diálogo, perpetraban características políticas y religiosas, principalmente al integrar en algunos casos los cánones postridentinos, como demostró Josep Lluís Canet en la Academia de los Nocturnos de Valencia $^{138}$.

Por otra parte, las academias fueron parte de prácticas humanísticas que colocaban a la palabra oralizada en lo más alto de los ideales humanísticos y también cortesanos. Justas poéticas, certámenes literarios e incluso la predicación forman parte de lo que Egido ha llamado "literatura efímera" o la "poesia all'improvisso"139, que tenían también un carácter altamente performativo ${ }^{140}$. Las manifestaciones poéticas formaban el rico ambiente de constante intercambio poético en el que estaban inmersos poetas y nobles y el 'vulgo' en general. Las academias, no obstante, fueron las reuniones que mejor lograron institucionalizar esta característica fundamental de la transmisión poética y de conocimiento ${ }^{141}$, priorizando en consecuencia sobre los demás géneros al diálogo. Afirma Amadeo Quondam:

in principio l'Accademia fu sotto il segno della conversazione. La sua stessa matrice originaria -così intensamente platonica nel propria del nome che assume tra horti e cenacoli umanistici mostra pienamente il primato di una convesazione come forma profonda dei rapporti culturali, come sistema di pratiche che trova nel dialogo il suo genere privilegiato e di massima funzionalità comunicativa. ${ }^{142}$

Sin embargo, no en todas las academias ocurrió así ${ }^{143}$, por lo que, al hablar del diálogo como género propio de la academia, quiero aclarar que debe asociarse solo a su forma más tradicional, cercana por tanto a la realidad italiana, a la que responderían las primeras o, en su defecto, más tradicionales academias en España. Es importante agregar que el aprecio por el diálogo dio paso a otros géneros igualmente unidos a la expresión oral como el discurso ${ }^{144}$. El ultimo era comúnmente utilizado para discusiones en donde se reflexionaba en torno a los más variados temas, entre ellos la naturaleza poética y sus características en general o particular.

En la mayoría de los casos, los discurso eran apologías de alguna postura en particular con respecto a una determinada manera de hacer poesía. De estos últimos, el más recordado sin lugar a duda es el “Arte nuevo de hazer comedias de este tiempo”, de Lope de Vega, leído entre 1607 y 1608

\footnotetext{
${ }^{138}$ Vid. "Estructura del saber y estructura del poder: organización y funciones de la Academia de los Nocturnos de Valencia", en Evangelina Rodríguez Cuadros, De las academias a la Enciclopedia: el discurso del saber en la modernidad, pp. 95-124.

139 "Literatura efímera...", pp. 73-75.

${ }^{140}$ Vid. M. Blanco, "La oralidad en las justas poéticas”, Edad de Oro, VII (1988), pp. 35-41.

${ }^{141}$ A propósito, comenta Lluís Canet: "La tarea de proporcionar a los humanistas oportunidades para la discusión e intercambio con sus colegas eruditos y sus protectores fue relegada a las academias” (op. cit., p. 98).

${ }^{142}$ Apud A. Egido, "La literatura efímera...", op. cit., p. 72, n. 16.

${ }^{143}$ Así ocurre, por ejemplo, en la academia de Valencia como señala Lluís Canet (vid. op. cit., p. 118).

144 Vid. id., pp. 105-111.
} 
en la Academia de Madrid $^{145}$, misma que se lo solicitó como lo recuerda el Fénix en la primera estrofa de su Arte:

$\mathrm{Ma}[\mathrm{n}]$ dame ingenios nobles, flor de España

Que en esta junta, y Academia insigne

En breue tiempo excedereis no solo,

A las de Italia, que embidiando à Grecia,

Illustrò Ciceron del mismo nombre,

Iunto al Auerno largo, sino à Athenas,

Adonde en su Platonico Lyceo,

Se vso tan alta junta de Filosofos,

Que vn arte de Comedias escriua,

Que al estilo del vulgo se reciba. ${ }^{146}$

Con tal resultado de una academia, se entiende que eran verdaderos lugares de diálogo para compartir conocimientos, principios y hasta puntos de encuentro para denostar a un poeta en particular. El caso de Juan Ruiz de Alarcón en 1623 es un elocuente ejemplo, pues un grupo de poetas y humanistas entre ellos Jáuregui y Cascales-, encabezados por Francisco de Quevedo, se reunieron para revisar la obra del mexicano y acusarlo, en su condición de poeta, de plagio ${ }^{147}$.

\section{El ideal del cortesano y su necesidad de poéticas}

La solicitud de los "ingenios nobles" de la Academia de Madrid a Lope demuestra veladamente otro aspecto primordial de las academias y que explica mucho de las dinámicas culturales ligadas al poder y a sus necesidades. Tal aspecto entonces responde al hecho de que una parte importante del público que asistía a las academias eran nobles, con necesidades particulares. Durante el "Libro primo" de $I l$ libro del Cortigiano de Castiglione, se describe detalladamente la corte donde se lleva a cabo el diálogo entre nobles para descubrir a través de un juego intelectual qué es lo que hace al perfecto cortesano. Todo esto precedido por la duquesa de Urbino, Elisabetta Gonzaga, esposa de Guidobaldo de Montelfetro. Este último, cuenta Castiglione:

procurava che la casa sua fusse di nobilissimi e valorosi gentilomini piena, coi quali molto familiarmente viveva, godendosi della conversazione di quelli [...], ed aver insieme con l'affabilità e piacevolezza congiunta ancor la cognizione d'infinite cose [...]; e con le parole, or corregendo or laudando ciascuno secondo i meriti, chiaramente dimostrava quanto giudicio circa quelle avesse; onde nelle giostre, nei torniamenti, nel cavalcare, nel maneggiar tutte le sorti d'arme, medesimamente nelle feste, nei giochi, nelle musiche, in somma in ttti gli

\footnotetext{
${ }^{145}$ Vid. Enrique García Santo-Tomás, “Introducción” para Lope de Vega, Arte nuevo de hacer comedias, pp. $43-$ 44.

146 Lope de Vega Carpio, Rimas de Lope Vega Carpio, pp. 360-361 (disponible en línea: http://bdh.bne.es/bnesearch/CompleteSearch.do?languageView=es\&field=todos\&text=rimas+lope \&showYearItems=\& exact=on\&textH=\&advanced=false \&completeText=\&pageSize=1\&pageSizeAbrv=30\&pageNumber=2).

147 José Sánchez, Academias literarias del Siglo de Oro, pp. 53-54.
} 
esercizi convenienti a nobili cavalieri, ognuno si sforzava di mostrarsi tale, che meritasse esser giudicato degno di cosí nobile comerzio. ${ }^{148}$

En otras palabras, la corte de Urbino era el prototipo de corte renacentista italiana, en donde, al igual que la academia, la palabra era la moneda de cambio con la cual los individuos se hacían no solo merecedores de su lugar en la corte, sino también de la noble compañía con la que gozaban de intrincadas discusiones, como las que Castiglione tiene a bien relatar, inmortalizando así una visión de lo que un cortesano debía ser.

La corte de Urbino, al volverse el punto de referencia para los hombres del renacimiento ${ }^{149}$, influyó con fuerza a España y más aún con la valiosísima traducción del Cortigiano realizada por Boscán ${ }^{150}$. De hecho, los Reyes Católicos, una vez pacificada la península ibérica, se preocuparon por la creación de círculos humanísticos, "donde la nobleza se ve casi constreñida al estudio de la oratoria y las artes, asimilando el carácter del perfecto cortesano descrito por Castiglione"151. El proyecto fue lo suficientemente exitoso para que la corte de Madrid se volviera un centro de referencia digno de imitar por nobles y humanistas provincianos que la visitaban y trasladaban sus principios a sus propias cortes al regreso de su viaje ${ }^{152}$. Por supuesto, la nueva característica adquirida por la nobleza debía de ser constantemente puesto en práctica y qué mejor que crear espacios destinados al diálogo con intelectos versados en los studia humanitatis.

En efecto, fue la nobleza la principal promotora de las academias a donde invitaban a todo tipo de humanistas para perfeccionar tanto su retórica como su poesía, a la par que satisfacían su deseo siempre imperante de iniciarse en nuevos temas con los cuales crear nuevos discursos para deleitarían a sus pares, ya que, según el Cortigiano, era el saber la materia prima de cualquier conversación ${ }^{153}$. Por tal motivo, así como la necesidad de los nobles por buscar espacios donde practicar atravesó los muros de la corte, su necesidad de aprender ciertas bases en las diferentes artes liberales atravesó la oralidad y se aunó al imperante deseo del Renacimiento de enciclopedismo ${ }^{154}$ para materializarse en doctrinas escritas ${ }^{155}$, que igualmente fueron leídas en las academias o las cortes,

${ }^{148}$ Op. cit., p. 21.

149 Incluso en el siglo XX, la crítica sigue utilizando el referente de Castiglione para desentrañar el funcionamiento de las cortes renacentistas (vid. Peter Burke, "Il Cortigiano", en Eugenio Garin ed., L'uomo del Rinascimento, pp. 133-165).

${ }^{150}$ Sobre la importancia de Castiglione y Boscán para la formación de la idea del cortesano en España es imprescindibles la obra de Margherita Morreale (Castiglione y Boscán: el ideal cortesano en el Renacimiento español, Madrid, Anejos del Boletín de la Real Academia Española, 1959), quien pone en relación la realidad política y social de ambas penínsulas, a partir de un estudio semántico de las opciones lexicales utilizadas por Boscán para su traducción,.

151 J. Lluís Canet, op. cit., p. 99.

152 Vid., F. J. Álvarez, et. al., op. cit., pp. 312-313.

153 B. Castiglione, op. cit., p. 73.

154 Vid. Paolo Cherchi, "Enciclopedias y organización del saber de la antigüedad al Renacimiento", en E. Rodríguez Cuadros, op. cit., pp. 86-94.

${ }^{155}$ Señala Aurora Egido que "conviene tener en cuenta que la dignitas hominis asignaba precisamente a la lengua su marca mayor, pues, gracias a ella, se podía acceder luego al resto de los saberes. En este sentido, la escritura prolongaba 
como ocurrió con el "Arte” de Lope de Vega. En consecuencia, el "noble o burgués debían dominar la composición poética si quería participar y alcanzar fama y renombre entre sus propios conciudadanos"156. La palabra poética había alcanzado un papel tan importante dentro de los ideales cortesanos y humanistas que se necesitaban poéticas didácticas que pudiesen brindar las herramientas necesarias para que el noble y el burgués se integraran al nuevo círculo social. Así pues, queda explicado que Rengifo con su "sylva de rimas" haya sido la poética más editada, distribuida y hasta menospreciada por los grandes poetas de su época, ya que ofrecía herramientas para facilitar la creación poética, justo lo que los neófitos buscaban. Y no solo, puesto que el ambiente de poesía leída en voz alta incluso en plazas públicas traía consigo otro gran participante de la poesía de los siglos XVI y XVII: el vulgo, a quien los principios del humanismo español no podían dejar desatendido.

\section{El gran público oidor: el vulgo y sus instructores}

La poesía no solo fue para humanistas y nobles. Si bien no todos los certámenes y justas eran públicos, existía una gran difusión de la poesía gracias a la oralidad que aún imperaba en el Siglo de Oro. Afirma Gustavo Illades Aguiar que en 1499 el primer público de La Celestina "vivía en un mundo esencialmente oral, en el que la voz audible era medio y fin de lo que hoy llamamos "literatura"' ${ }^{157}$. Por ende, ante la novedad que representaba este diálogo en prosa, Alonso de Proaza agregó instrucciones a la edición de 1500 para que el lector en voz alta leyese correctamente ${ }^{158}$.

El caso no es aislado como se observa en la forma tan minuciosa con la que la palabra escrita servía a la vocalizada. Esta cualidad fue ampliamente ilustrada por Margit Frenk en su ensayo "La ortografía elocuente", donde demuestra cómo las letras y la puntuación estaban al servicio del público oidor $^{159}$. Ahora bien, es verdad que en los siglos XVI y XVII ya prevalecía la oralidad segunda, que, según Paul Zumthor, se refiere a una construida a partir de lo escrito, vinculada por lo mismo a la cultura erudita ${ }^{160}$. Sin embargo, verbos como leer, mirar, oír y escuchar -ha observado Frenk- eran la mayoría de las veces intercambiables entre sí ${ }^{161}$. Además, la población humilde, la más numerosa, era analfabeta por lo cual, incluso siendo participe de la oralidad mixta y segunda al ser un público oidor, estaba estrechamente ligada a la oralidad primera de la Edad Media ${ }^{162}$, estudiada por

\footnotetext{
y fijaba dicha dignidad a través de un ejercicio que era mucho más que la plasmación gráfica, pues remitía a un mundo interior conceptual del que esta derivaba" ("La dignidad humanística de la escritura", Bulletin Hispanique, t. 114, no. 1, 2012, p. 10).

156 J. Lluís Canet, op. cit., p. 121.

157 “Observaciones sobre la actio del lector. (De La Celestina a la sátira anónima novohispana)", Escritos. Revista del Centro de Ciencias del Lenguaje, 26 (2002), p. 13.

${ }^{158}$ Vid. id., pp. 14-16.

${ }^{159}$ Vid. Entre la voz y el silencio. La lectura en tiempos de Cervantes, pp. 86-99.

${ }^{160}$ Vid. La letra y la voz. De la 'literatura' medieval, p. 21.

${ }^{161}$ Vid. "Ver, oír, leer...", Entre la voz y el silencio, pp. 100-120.

162 Vid. M. Frenk, "Lectores y oidores en el Siglo de Oro", Entre la voz..., p. 49.
} 
Zumthor ${ }^{163}$. Es también pues este público el que escucha La Celestina, el Quijote, y, especialmente, el que asiste a los corrales para deleitarse con la comedia nueva y al que los preceptistas y poetas llamaron genéricamente vulgo.

El vulgo es un concepto que, como analiza Alberto Porqueras a través de la literatura bíblica, no siempre tiene una aplicación peyorativa. Asimismo, según Porqueras, si se hacía una referencia claramente 'ofensiva', se seguía la tradición clásica romana que partía del odi profanum vulgus horaciano, para denotar no tanto un desprecio real, sino una suerte de captātı̆o benevolentiae. Era pues un recurso retórico para ganarse el favor de su público, generalmente noble ${ }^{164}$; es decir, de los “ingenios nobles" de Lope de Vega. Por lo tanto, el ataque al vulgo en la mayoría de los casos es una "fórmula manierística", lo que explica que los "prólogos al vulgo constituyeron una moda grata a algunos escritores del manierismo español" ${ }^{\prime 65}$.

Tal visión es compartida parcialmente por Javier García Gibert, quien ve además en el tratamiento al vulgo una forma de establecer una aristocracia de espíritu y carácter contrapuestos al elitismo estamental, al más puro estilo del humanismo:

Lo que se propugna precisamente es establecer las diferencias entre la aristocracia hereditaria y la aristocracia del espíritu, atribuyéndole a ésta todo el honor, que se fundaba en el mérito personal del saber y la virtud, no en la sangre o el linaje. La pertenencia o no al vulgo es, en definitiva, una opción personal, fundamentada en el libre albedrío y la voluntad de luchar por el perfeccionamiento y contra la ignorancia. [...] Porque la ignorancia a la que se alude es siempre en el fondo una deficiencia de carácter más ético que libresco y más referida a la sabiduría que a la cultura. ${ }^{166}$

Bajo esta luz se puede entender el valor pedagógico que adquiere el humanismo español a través de la palabra, máxima representante de la dignidad humana. Así lo sintió -supone Porqueras MayoLope de Vega y sus secuaces, porque, entre los diferentes géneros de los Siglos de Oro, el teatro fue el que más se enfrentó a este público caprichoso, atento oidor y deseoso de novedades ${ }^{167}$.

Gracias a la relación del vulgo con la dignidad de la comedia nueva, se veía en esta el método con el cual "empezar por abajo, para agradar al vulgo y, así, poco a poco, transformarlo en un auditorio instruido, dramáticamente especializado, producto de una constante modelación del poeta que conseguirá extraer de él un arte de nuevo cuño que será la tragicomedia"168. Sin embargo, hay

${ }^{163}$ Zumthor define la oralidad mixta "cuando la influencia del escrito sigue siendo externa, parcial y con retraso" (op. cit., p. 21), mientras que la oralidad primera se realiza únicamente "en sociedades desprovistas de todo sistema de simbolización gráfica, o en grupos sociales aislados y analfabetos" (id., pp. 20-21), como afirma también Ong en su libro Oralidad y escritura: tecnologías de la palabra (vid. p. 40).

${ }^{164}$ Vid. A. Porqueras Mayo, "El concepto ‘vulgo' en la Edad de Oro”, Temas y formas de la literatura española, pp. 114-117.

${ }^{165} I d .$, p. 118.

166 J. García Gibert, op. cit., p. 77.

167 Vid. "Función del 'vulgo' en la preceptiva dramática de la Edad de Oro", en F. Sánchez Escribano y A. Porqueras Mayo (eds.), Preceptiva dramática..., pp. 367-368.

${ }^{168}$ Id., p. 373 y vid. p. 377. 
que alertar con Porqueras que esta actitud del Fénix se compenetra con la época en la que escribió el Arte, la que cambia paulatinamente cuando su enfoque se volvió más 'libresco'169. Quiero resaltar este particular pues ahora delimitaré a grandes rasgos una serie de características vinculantes entre las cinco poéticas a revisar, a partir de lo expuesto hasta ahora.

\section{POÉTICAS DIALÓGICAS Y DISCURSIVAS: CARACTERÍSTICAS VINCULANTES DE CINCO POÉTICAS}

Las vidas de Alonso López Pinciano (ca. 1547-?), Luis Alfonso de Carvallo (1571-1635), Francisco Cascales (1564-1642), Luis Carrillo y Sotomayor (ca. 1585-1610) y Juan de Jáuregui y Aguilar (1583-1641) ${ }^{170}$ se entretejen de formas complejas en el entramado sociocultural de la España de los siglos XVI y XVII. De hecho, representan una curiosa gama de diferentes tipos de humanistas que se podían encontrar en la época: un médico de la corte con una gran curiosidad por los temas poéticos, un jesuita apasionado por la enseñanza, un profesor provinciano con una importante injerencia en justas poéticas, un soldado poeta y un pintor poeta muy activo en los certámenes y justas poéticas, perteneciente a la Academia de Juan de Arguijo ${ }^{171}$. Además, a excepción de Pinciano, todos eran descendientes de familias acaudaladas o de importantes linajes, lo que explica su viaje y en la mayoría de los casos su permanencia por una breve temporada en Italia -el caso de Carrillo y Sotomayor no es del todo claro. Su relación con el ambiente cultural italiano tuvo sin lugar a duda importantes consecuencias, pues es bastante probable que aquí hayan tenido acceso a una parte importante de sus

${ }^{169} I d .$, p. 374, n. 16.

${ }^{170}$ Para las referencias biográficas revisé el ya canónico trabajo de Antonio Vilanova, op. cit., pp. 603-659 passim, y las eruditas notas de M. Newels para Pinciano, Carvallo y Cascales (op. cit, pp. 21-32). De igual forma consulté los siguientes estudios específicos hechos para cada humanista.

1) Alonso López Pinciano: vid. Pedro Muñoz Peña, "Introducción” para A. López Pinciano, Filosofía Antigua Poética, pp XI-XVII (disponible en línea: https://archive.org/details/filosofiaantiqua00lpez); S. Shepard, op. cit., pp. 25 27 y José Rico Verdú, “Introducción” para A. López Pinciano, Obras completas, I, Philosophía Antigua Poética, pp. IXXX.

2) Luis Alfonso de Carvallo - conocido tradicionalmente por su segundo apellido-: vid. A. Porqueras Mayo, "Introducción", op. cit., pp. 1-8.

3) Francisco Cascales: vid. F. Cerdá y Rico, "Prologo al lector" para F. Cascales, Tablas poeticas, pp. III-XIV (disponible en línea: http://bdh-rd.bne.es/viewer.vm?id=0000091370\&page=1); Justo García Soriano, El humanista Francisco Cascales. Su vida y sus obras. Estudio biográfico, bibliográfico y crítico, pp. 7-71; A. García Berrio, op. cit., pp. 13-42.

4) Luis Carrillo y Sotomayor vid. Manuel Cardenal Iracheta, "Nota bibliográfica" para L. Carrillo y Sotomayor, Libro de la erudición poética, pp. VII-XI; Dámaso Alonso, "Sobre Don Luis Carrillo", Obras completas, III, Estudios y ensayos sobre literatura. Segunda parte. Finales de siglo XVI, y siglo XVII, pp. 701-735; Fiorenza Randelli Romano, op. cit., pp. 13-35; Angelina Costa, "Introducción” para L. Carrillo y Sotomayor, Libro de la erudición poética, pp. 11-21; Rosa Navarro, op. cit., pp. 9-31.

5) Juan de Jáuregui y Aguilar vid. José Jordán de Urríez y Azara, Biografia y estudio crítico de Jáuregui, pp. 156; Inmaculada Ferrer de Alba, "Introducción” para J. de Jáuregui, Obras, I, Rimas, pp. V-XLIII, Melchora Romanos, "Don Juan de Jáuregui: vida y obras", en J. de Jáuregui, Discurso poético. Advierte el desorden y engaño de algunos escritos, pp. 9-27. aclaración.

En caso de citar algo que no pertenezca a estos trabajos, o a una página diferente de lo señalado, haré la

${ }^{171}$ Vid. J. Sánchez, op. cit., pp. 203-204. 
fuentes utilizadas para la realización de sus poéticas - como ha supuesto García Berrio con Cascales. Su contacto con la cultura de la península itálica marcó también con fuerza sus intereses y reflexiones poéticas, como lo demuestra la traducción de la Amnita de Tasso por Jáuregui.

Por otra parte, la proximidad cronológica entre estos humanistas los hace confluir en diferentes ocasiones. Así, se sabe que Cascales y Jáuregui se encontraron en la Academia de Madrid en 1623 (vid. supra) y es un hecho que Carrillo participó en el círculo humanístico de Cascales, a quien se refiere en sus cartas. Los puntos de encuentro no son solo físicos, sino también intelectuales. De Pinciano y de Carvallo no se sabe que hayan asistido a academias o que hayan participado en justas o algún otro tipo de concurso poético, puesto que no eran poetas, pero sí existe la hipótesis de que al menos el segundo conocía la obra del primero y que la tuvo presente durante la construcción de su Cisne. Igualmente ocurre con Cascales, quien sí menciona directamente al Pinciano, para buscar contradecirlo.

Más allá de esta relaciones intertextuales y silencios significativos, es evidente que lo que más une a estos cinco humanistas son los textos que leen u oyen en las universidades, colegios, círculos, academias y corte. Hecho que les permitió estar en sintonía con las problemáticas poéticas de su momento. Por un lado, Pinciano, Carvallo y Cascales intentaron salvar a su manera la carencia que sentían de poéticas españolas; por otro, Carrillo y Jáuregui se posicionan con respecto a la estética del lenguaje poético en boga, que mostró su mayor exponente en la figura de Luis de Góngora, cuya obra originó una acalorada y dinámica polémica ${ }^{172}$.

Con base en lo anterior, siguiendo el ejemplo de Menéndez Pelayo ${ }^{173}$, haré una distinción bipartita de las cinco poéticas a analizar. Estos dos grupos permitirán a su vez englobar características fundamentales que pondrán en relación más fácilmente a las poéticas de cada grupo. Sin embargo, tal clasificación no debe ser vista como limitante o separatista, sino como una guía que permitirá la comprensión del campo literario del que estas hacen eco al responder a necesidades concretas. La Fig. I.1. muestra entonces una división que responde a la forma en la que están estructuradas las poéticas, lo que no significa que estén restringidas a un género en particular.

${ }^{172}$ A propósito dicen Alejandro Gómez Camacho y José Manuel Rico García: "El año de 1617, fecha de la publicación de las Tablas de Cascales, del Pasajero de Cristóbal Suárez de Figueroa, y de la entonces ya extendida difusión manuscrita del Antídoto de Juan de Jáuregui contra la poesía de las Soledades gongorinas, representa un momento decisivo para la historia de las ideas estéticas en nuestro país: los tratados, opúsculos, pareceres y comentarios de la más diversa naturaleza van a servir de testimonios de la discusión sobre la lengua poética barroca" ("La oda en preceptivas y tratados españoles”, en B. Bueno López, ed., La oda. II Encuentro Internacional sobre Poesía del Siglo de Oro, p. 408).

${ }^{173}$ Vid. M. Menéndez Pelayo, op. cit., pp. 205-206. 


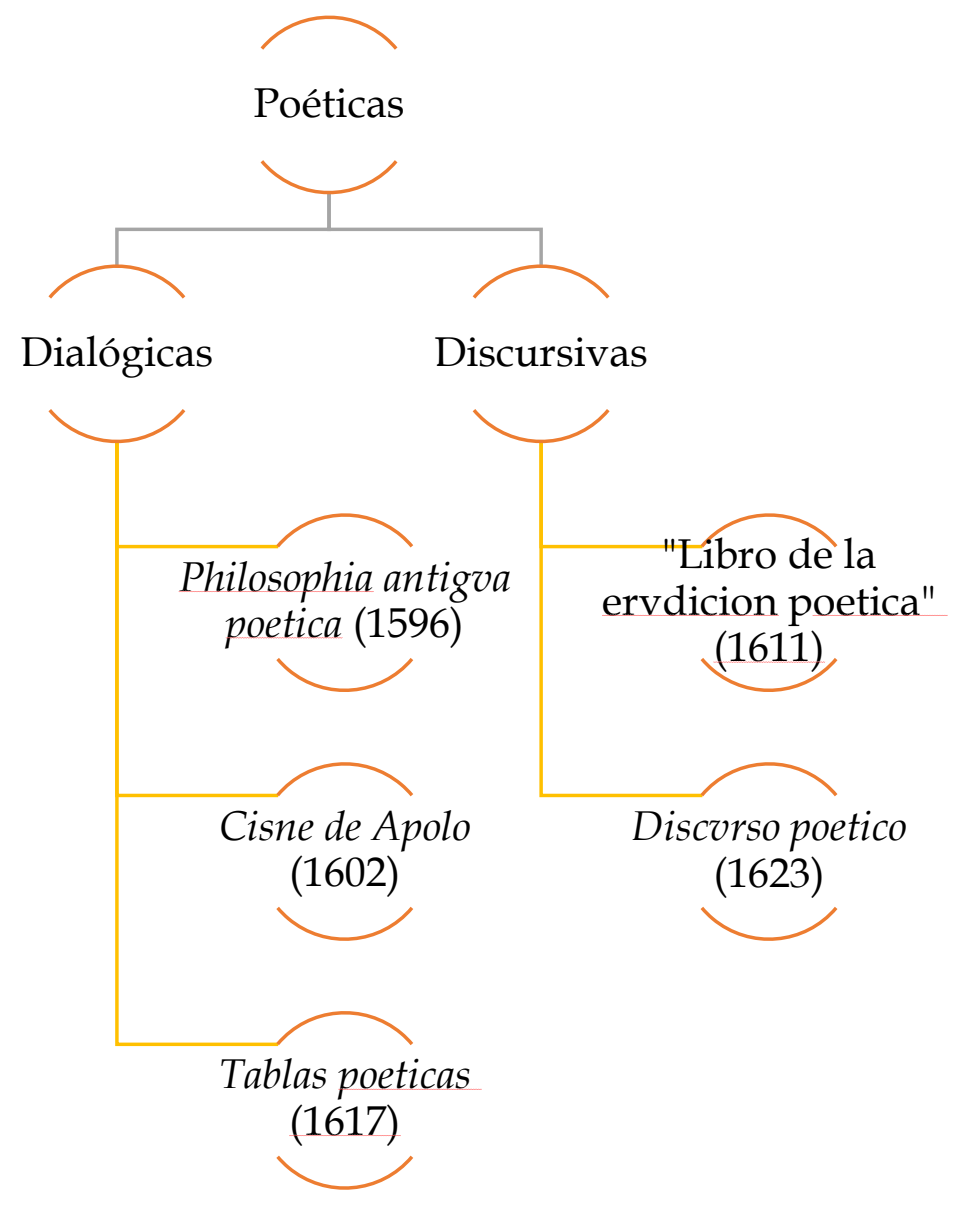

Fig. I. 1: División de poéticas

\section{Poéticas dialógicas}

Las tres poéticas que conforman el grupo de las "poéticas dialógicas" responden a la explotación del género priorizado en las academias renacentistas italianas: el diálogo, pero las poéticas no responden únicamente a este género. Pinciano, Carvallo y Cascales hacen confluir varios géneros, cumpliendo un principio de variedad, indispensable en la época ${ }^{174}$. Pinciano conforma su diálogo con tres personajes, pero las reuniones - microcosmos de una reunión humanista- están divididas en epístolas, puesto que hay un cuarto participante que no está presente físicamente, mas sí a través de otro género importante de la época: la epístola, misma que pedagógicamente sirve para enumerar los principales puntos tratados. Carvallo y Cascales también ejemplifican sus enseñanzas echando mano del diálogo. El primero, sin embargo, tiene dentro de sus tres personajes uno alegórico, la Lectura, para seguir con la tradición medieval, posiblemente heredada de sus fuentes enciclopédicas como Badius Ascensius, de quien, al igual que se vio con Cascales, Carvallo no siempre vuelve explícitas sus constantes citas y su pensamiento medieval. 
Carvallo entonces continúa con la tradición del Cortiggiano o de las Prose de Bembo, al explicar que lo que reproduce en su poética es el resultado de un diálogo humanístico, ligado a una tradición plenamente renacentista (vid. Cisne, III2r-v). El Cisne se divide en cuatro diálogos y cada uno de ellos tiene diferentes apartados. Además, confluyendo siempre con la vărĭātĭo, resume en octavas al final de cada apartado, pues se rescata al verso como estrategia mnemotécnica. Lo cual, más allá del valor poético que puedan tener, fue aprovechado por los editores del siglo XVIII de la Poética de Rengifo, quienes refundieron únicamente las octavas del Cisne con el resto de la poética métrica. Finalmente, Cascales, con los dos participantes de su diálogo, no hace uso de alguna estrategia para resumir sus enseñanzas, pero, en su lugar, vulgariza y comenta el Arte poética de Horacio, a la más pura usanza de los comentaristas italianos, aunque no con el mismo rigor. Y para la vărīătĭo, Cascales agrega un sinfín de versos italianos para ejemplificar parte de su "Poesia in specie".

Otro aspecto que quiero resaltar de estas poéticas dialógicas es su estrecha relación con las poéticas “clásicas”-según la expresión de Menéndez Pelayo-, pues basan sus principios en la Poética aristotélica, lo que no significa que sean serviles a esta. De hecho, pueden ser consideradas clásicas en tanto que continúan una discusión iniciada con el redescubrimiento de la Poética; así, se unen al discurso de la dignificación de la poesía siguiendo las cuatro causas aristotélicas: material, formal, eficiente y final. Consecuente con esto, Pinciano explica que el nombre de su poética, Philosophia antigva poetica, se debe a que

assi Maximo Tirio Philosopho Platonico a la Poetica llama, y assi lo es realmente, y se vee al ojo, q[ue] los Philosophos mas antiguos enseñaron su Philosophia co[n] imitaciones Poeticas, y que los mas modernos la enseñaro[n] sin ellas despues. Deste nombre ha[n] huydo nuestros Españoles con justa razon, los quales en sus libros no han dado Philosophia antigua, ni au[n] moderna, sino tocado solamente la parte que del Metro habla. (“Al lector”, s. f.)

En otras palabras, se procura recuperar el valor cognoscitivo que la poesía tenía para los antiguos, aún si esto significaba subordinarla a la filosofía. Tal hecho no representa un problema para un médico como Pinciano, que sigue de cerca las enseñanzas de Huarte de San Juan y hereda la preminencia de la razón ${ }^{175}$, lo que se refleja elocuentemente en la "Epistola primera, o introduction a la Philosophia antigua. Trata de la Felicidad humana”. Alejar a la poesía de una consideración meramente métrica -reproche que Pinciano y, más adelante, Carvallo dirigen veladamente a Sánchez de Lima y a Rengifo- es el primer objetivo del humanista y lo evidencia con el título que nombra su poética. A esto se aúnan las diferentes reflexiones que Carvallo y Cascales hacen a su vez para dignificar el papel de la poesía, principalmente a través del dǒcēre ĕt dēlectāre horaciano.

${ }^{175}$ Vid. S. Shepard, op. cit., pp. 28-40. 
El dŏcēre, siguiendo con el debate desarrollado en Italia durante el siglo XVI, se reafirma con la imitación aristotélica. La Poética, no obstante, funge únicamente como base, pues cada poética la enriquece con otras fuentes y las reflexiones de cada humanista hasta conseguir una definición más moderna. Así consta en las Tablas poeticas, donde se va más allá de la imitación de acciones hechas por el individuo: "La Poetica es arte de imitar con palabras. Imitar es, representar, y pintar al viuo las acciones de los hombres, naturaleza de las cosas y diuersos generos de personas, de la misma manera que suele ser, y tratarse" (f. 13) ${ }^{176}$.

Todas estas disertaciones, además de ser la 'vulgarización' de los comentarios italianos, tienen como objeto particular ilustrar a un individuo que se proponga iniciar su producción poética o bien a un poeta en ciernes al que le falte los principios teóricos. Principalmente a esto último se atiene López Pinciano, ya que, si su Lector fuese ya un iniciado y necesitase práctica, encuentra ya una solución en Escalígero. Se propone, en suma, ofrecer una síntesis de la teoría poética ${ }^{177}$. Sin embargo, la intención se puede interpretar también como una manera de salvarse ante la crítica, puesto que el vallisoletano es, después de todo, un médico de corte.

En cuanto a Carvallo y Cascales, sí puede notarse más la ambición de adoctrinar al poeta. Ambición entendida en su justa proporción, pues se trata de dos profesores, cuya motivación potencializa la "proyección pragmática y pedagógica, más que erudita y filológica"178 del humanismo español. En el Cisne de Apolo dice Carvallo:

Soberuia fuera grande mia, querer sujetar los delicadissimos ingenios de Vs. Merecedes a reglas y preceptos mios, queriendo poner limitacion, y orden, a la subtileza de las obras, que tanto a toda arte exceden. Mas no fue tal mi intento, sino solo juntar en este breue tratado, todo lo que a este arte toca, de que tanta necesidad ay en España. (IIIr)

Lo que no le impide agregar al final de su advertencia -“A los discretos Poetas el Auctor"-: "Todo lo ofrezco a la fabrica de las obras de Vs.ms." ( $₫ \uparrow \mid 3 r)$, donde se muestra que de cualquier manera Carvallo sí dirige a poetas su obra.

Cabe agregar que los poetas que tiene en mente el asturiano son 'discretos', es decir que pertenece a esa categoría de "hombre cuerdo y de buen seso, que sabe ponderar las cosas y dar a cada vna su lugar", según nos informa Covarrubias ${ }^{179}$. En estos pasajes, iniciando con el adjetivo usado, confluyen la captātı̌o benevolentiae y el principio platónico del furor, que será ampliamente defendido por Carvallo a lo largo de su poética. Asimismo, como Pinciano, insiste en que ofrece un "breue tratado" para subsanar la carencia de poéticas en España.

\footnotetext{
${ }^{176}$ Vid. A. García Berrio, op. cit., pp. 55-58.

177 Vid. Philosophia, "Al lector", s. f.

178 J. García Gibert, op. cit., p. 26.

${ }^{179}$ Tesoro de la lengva castellana, o española, p. 321v.
} 
Cascales parte igualmente de dicho lugar común, reafirma la necesidad de preceptos y agrega siempre con falsa modestia:

consulta tu a los hombres versados, y practicos: oye sus preceptos, y con ellos escriue obras heroicas, scenicas, y lyricas, si quieres co[n] justo titulo ser saluado por Poeta. Y mientras no tuuieres a la mano otros maestros de Poesia, al mar te[m]pestuoso arrojo estas Tablas Poeticas: quando te fueres anegando en el golfo de la dudosa confusion, arrimate a ellas, y por ventura saldras a la orilla saluo y libre de la torme[n]ta. (Tablas, "Prologo", s. f.)

En breve, Cascales ofrece una poética salvavidas, que, a discreción del lector, debe ser consultada solo cuando los textos de "hombres vesados, y practicos" no estén a la mano. Recuérdese que, pese a su papel activo como juez en justas y certámenes, el murciano -al igual que Pinciano y Carvallo- no es poeta.

La poca práctica que los autores tuviesen en el arte del verso no imposibilita a ninguno de los tres, como humanistas, tratar el tema de la poesía incluso con autoridad. Esta la han adquirido con sus fuentes librescas, aunque no podría asegurar que sus reflexiones se atuvieran únicamente a lo escrito, dada su participación en lugares que pasaba gran parte del tiempo en discusiones teóricas de todo tipo. Sin embargo, a diferencia de las poéticas discursivas, es innegable que sus principios teóricos están más asociados a una realidad escrita y erudita, lo que no les impide ser útiles para nobles o burgueses con ambiciones poéticas o bien a un vulgo que puede ser aleccionado. Así pues, en este aspecto, disiento de Porqueras Mayo, para quien los

Preceptistas, al hablar de literatura, intentaran dar normas para los autores. Los autores quieren seguir a los preceptistas, pero su creación se mueve a causa de unas sacudidas violentas, que los preceptistas han desconocido. Se trata de un nuevo factor: el lector, el público. Los preceptistas escriben para los autores. Los autores escriben para los lectores. ${ }^{180}$

Efectivamente, humanistas no poetas como los que escribieron estas poéticas dialógicas no tenían la presión del vulgo o de lectores - entendiendo tal término con toda la ambivalencia documentada por Frenk. Así me explico en parte una de las razones que separaban a la teoría de la práctica poética. No significa, empero, que los preceptistas no hayan pensado también en un público no de potenciales poetas, pero sí con intenciones de aprender cómo leer poesía y cumplir en parte con la imagen del cortesano ideal.

En consecuencia y si bien puede leerse como nota manierística -siguiendo la interpretación de Porqueras-, Carvallo asegura que el principal objetivo de su trabajo es "satisfazer al ignorante vulgo, con quien ta[n] mal acreditados estan los Poetas, que sus obras juzgan por locuras y vanidades, sin traça ni concierto, libres de toda regla y limitacion, y por lleuar este fin de sacarle de tal ceguera y darle a entender que ay orden y concierto en esto, como en qualquiera arte" (Cisne, $\mathbb{T}[\llbracket \mathrm{r}-\mathrm{v})$; y con 
base en esto llama a su trabajo "Arte poetica” (id., IIIr). Buscar la dignificación de la poesía entre el vulgo que no la entiende es la segunda -y tal vez primordial- función pedagógica de Carvallo, ya que este lugar común ${ }^{181}$ adquiere otro nivel semántico al personificar en Zoylo el parecer común ${ }^{182}$. De tal guisa, se procura desmentir errores del vulgo y entonces educarlo. Carvallo no pretende únicamente "dignificar la poesía por encima de prejuicios vulgares" ${ }^{183}$, sino acabar a su vez con tales prejuicios a través de su saber enciclopédico. El objetivo es compartido en parte por Pinciano y Cascales, quienes no mencionan al vulgo directamente como Carvallo, pero sí personifican algunas de sus particularidades en las figuras de Pinciano y Pierio, quienes son educados por Fadrique y Castalio respectivamente, al igual que Zoylo por la Lectura.

\section{Poéticas discursivas}

Más cercanas al fenómeno oral de los Siglos de Oro, las poéticas de Carrillo y Jáuregui parecen seguir lo que Emilio Orozco opina sobre el "Arte" de Lope de Vega, quien habría hecho una obra de circunstancia, según la opinión del crítico. Así pues:

Arte nuevo no es [...] formalmente un poema didáctico ni una epístola de contenido doctrinal simplemente concebida para ser leída con forma y tono personal; es esencialmente, una pieza de oratoria, un nuevo tipo especial de discurso académico de vivo y cambiante tono entre engolado y familiar con sus toques de humor - más cercano a una breve charla de hoyconcebido, espontáneamente, en relación con el sentido del soliloquio, pero desarrollado atendiendo a las partes y normas de la retórica aristotélica, aunque dentro de la libre $-\mathrm{y}$ a veces contradictoria- interpretación de ésta que le da el Barroco. ${ }^{184}$

El "Libro de la ervdicion poetica" y el Discvrso poetico no son poemas y no fueron preparados por solicitud de una academia, hasta donde se sabe. Por otra parte, ambos textos son bastantes serios y mantienen un registro alto en todo momento, lo que no deja de hacerlos bastantes personales y en ocasiones hasta viscerales ${ }^{185}$. Sin embargo, me parece que son compatibles con el "Arte" de Lope porque son piezas de oratoria y son igualmente consecuentes con las peculiares normas de la retórica aristotélica de la época. Bajo este principio, y a diferencia de las poéticas dialógicas, las discursivas

${ }^{181}$ Un argumento similar esgrime Fernando de Herrera en su dedicatoria a D. Antonio de Guzmán: "me quise obligar al juizio delos que tiene[n] menos conocimiento desto, que son los que condenan con mas rigor i menos justicia los errores agenos" (op. cit., f. V).

${ }^{182}$ Como es bien sabido, este nombre-Zoilo-, hace además eco de la tradición clásica, pues se trata del gramático y filósofo griego que censuró a Homero, y cuyo nombre se asoció en los Siglos de Oro a la figura del pedante, como se observa, por ejemplo, en el Quijote de Cervantes. Carvallo, en su poética, recupera ambos significados para ironizar a los críticos y detractores de la poesía.

${ }^{183}$ A. Porqueras Mayo, "Función del 'vulgo'...”, p. 369.

184 ¿Qué el Arte nuevo de Lope de Vega?, apud E. García Santo-Tomás, op. cit., pp. 54-55.

185 Juan Matas Caballero hace notar el carácter esencialmente polémico en la obra crítica de Jáuregui, el cual efectivamente llega a su máximo con el Antídoto contra la pestilente poesía de las Soledades y, aun así, está también presente en el resto de su obra (vid. Juan de Jáuregui. Poesía y poética, pp. 227-230). 
no parecen acabadas, contrariando lo que podría esperarse de un texto impreso ${ }^{186}$. El peso de esta afirmación adquiere un valor significativo con la obra de Carrillo, debido a que nunca fue pasada por el torno en vida del autor (vid. "Nota preliminar", s. f.). No obstante, se leyó - tal vez en voz alta-en el círculo precedido por Cascales, tal y como su "Carta segvnda" lo advierte cuando defiende su estilo poético y prosístico de un desconocido miembro de dicho círculo:

halla (no me espanto) algunos lunares (llamemoslos assi) ya en la persona de mi Musa, ya en las persuasiones de mi prosa, à vnas imperfecciones, y à otras respondere, no defendie[n]dolas [...]. En efeto dos faltas se me ponen, demasiado cuydado en la prosa, y demasiada co[n]fusion (que es la verdadera escuridad viciosa) en vn Soneto desconozco esta culpa, pues no se qual Soneto mio aya llegado à sus manos de V[uestra] m[erced] y estotra, à saber, d[e]masiado cuydado en la prosa, Ex tempore, me ha parecido responder assi segun las ocasiones, assi son los estilos del escriuir. $\left(M_{1}\right.$, f. 141v)

Esta demostración de derecho a réplica concreta lo auténtico que era el diálogo entre Carrillo y otros humanistas, pues las cartas también podían ser leídas en público, ofreciendo a la posteridad el testimonio de una discusión humanística, gracias a su naturaleza escrita.

El caso del Discvrso poetico, impreso durante la vida de Jáuregui a diferencia de su Antídoto, no deja tampoco del lado este diálogo, puesto que nada más al ser publicado a la par que su Orfeo $^{187}$, se desató una gran polémica en torno suyo. Caso similar a la crítica hecha a Carrillo, a Jáuregui se le acusó de falta de coherencia entre su teoría y práctica tanto por parte del grupo encabezado por un desairado Lope de Vega, como por el encabezado por su eterno rival, Góngora ${ }^{188}$. Sin embargo, como señala Melchora Romanos, el Discvrso poetico concuerda totalmente con el Orfeo, en tanto que es la exposición teórica de una postura poética intermedia entre claros y oscuros que se pone en práctica en su poema mitológico -explicando así su aparición al mismo tiempo ${ }^{189}$. La poética de Jáuregui es esencialmente personal, al igual que lo fue el "Arte" del Fénix.

Por lo tanto, así como se puede acercar la división de las poéticas 'clásicas' de Menéndez Pelayo a las dialógicas, las poéticas discursivas pueden ser asociadas a las 'apologéticas'. Es un hecho que tanto el "Libro de la ervdicion poetica" como el Discvrso poetico son apologías de un determinado tipo de poesía: la primera a lo que el mismo título de la poética alude, la erudición poética, y la segunda a una poética que se ubica entre la poesía llana y la conceptista. Así, al revisar la argūmentātǐo de cada poética discursiva se verifica que sigue los modelos retóricos aristotélicos pero también los de la tradición latina- y se conforman como discursos demostrativos. En palabras

186 "Lo impreso produce una sensación de finitud, de que lo que se encuentra en un texto está concluido, de que ha alcanzo un estado de consumación". Y agrega más adelante Walter J. Ong: "Se supone que el texto impreso representa las palabras de un autor en su forma definitiva o "final', pues el medio natural de lo impreso es sólo lo concluido" (op. cit., pp. 208-209).

${ }^{187}$ Es bien sabido que el Discvrso carece de aprobación porque la que se había adjuntado al Orfeo valía para amabas obras.

${ }^{188}$ Vid. J. Matas Caballero, op. cit., pp. 221-226.

${ }^{189}$ Vid. op. cit., pp. 22-29. 
de Miguel de Salinas significa: “Cuando se alaba alguna virtud en general que de suyo es loable, basta por circunstancias mostrar haber sido mandado procurarse por leyes divinas y humanas y consejos de hombres sabios, poniendo ejemplos en que se vea haber sido siempre tenida en mucho" ${ }^{190}$. Luego, la erudición que Carrillo y Jáuregui despliegan no es gratuita. Cada cita y ejemplo de los "hombres sabios" - sus auctoritates - es un argumento a su favor para encumbrar en lo más alto sus ideales poéticos, lo que hace que Carrillo, hombre de gran santidad, recurra incluso a la divinidad de las Musas para autorizar la erudición poética.

Ahora bien, quiero recordar que estas poéticas discursivas, apologías que alaban determinados principios estéticos, se presentan como ataques ora contra los 'indoctos' $\left(M_{1}\right.$, f. $\left.109 \mathrm{v}\right)$, ora contra los "engaños de algunos escritos" (Discvrso, 1r). Se explican entonces las respuestas airadas que recibieron por parte de sus detractores. No obstante, a la par de las poéticas 'dialógicas', observo también la intención de educar a un lector u oyente. Carrillo ataca con su "Libro de la ervdicion poetica" esa ignorancia tan aborrecida por el humanismo español y Jáuregui está educando a un lector ideal para su Orfeo.

Las diferencias enunciadas hasta ahora con respecto a las poéticas dialógicas conllevan a una conclusión lógica, misma que se adivina con la recepción que tuvieron: estas dos poéticas no están hechas a espaldas de la producción poética, sino todo lo contrario. Asimismo, al ser básicamente discursos demostrativos y pese a tocar varios puntos de la poética clásica, no se conforman como poéticas tradicionales o clásicas. Claro ejemplo es que en ninguna de las dos se discuten o explican los diferentes géneros literarios. Es más, cuando la crítica actual expresa "sin Poeticas ay Poetas", no está pensando -en la mayoría de los casos- en Carrillo y Jáuregui, sino en Pinciano, Carvallo, Cascales, Salas, etc.

Pese a lo anterior, no me parece inadecuado integrar las poéticas discursivas a mí estudio. No porque siga con Rico García la tradición crítica de Menéndez Pelayo, Nicolás Antonio y Vilanova, que agrupan a Carrillo y a Jáuregui con el resto de las preceptivas ${ }^{191}$, sino porque, en principio, al igual que las dialógicas, son poéticas en tanto que analizan a su manera las cuatro causas aristotélicas para crear una idea de poesía. Por tanto, buscan también educar, aunque no es su principal objetivo. Además, lo más importante, el "Libro" y el Discvrso son el resultado de lecturas, discusiones y reflexiones en torno al fenómeno poético. Dicho de otro modo, la transición de una poética a otra, sus semejanzas y, aún más, sus diferencias son las que pueden mostrar una mejor prefiguración del significado de términos como agudeza e ingenio, en décadas cruciales que vieron cómo las plumas de Quevedo, Góngora, Lope y Cervantes estaban en el ápice de su creación y antes de que la

\footnotetext{
${ }^{190}$ Retórica en lengua romance, apud J. Lluís Canet, op. cit., pp. 107-108.

191 J. M. Rico García, op. cit., p. 94.
} 
objetividad resultante de la distancia temporal le permitiera a Gracián escribir su Agudeza y arte de ingenio.

Para que tal propósito se resuelva felizmente, empero, se requiere estar siempre conscientes de un aspecto que las cinco poéticas comparten y que ya he mencionado: su carácter inconcluso, ya que incluso las poéticas dialógicas pudieron ser leídas en público. Afirma Frenk que en "el Siglo de Oro, la poesía, los cuentos, la narrativa más extensa, los diálogos, las cartas, las crónicas, los tratados: toda suerte de escritos se leía en voz alta o se recitaban de memoria, a la par que las obras teatrales, y las poesías solían cantarse" ${ }^{192}$. Indicativo de esto son las epístolas que resumen los diálogos en la Philosophia Antigva Poetica o las octavas mnemotécnicas de Carrillo-quien además divide en breves apartados los diálogos-, sin olvidar la vărĭătı̆o incluida en todas las poéticas, hecho que tanto encantaba a los oyentes ${ }^{193}$. Tal apertura obliga una lectura atenta, pues al no ser textos terminados los indicios esparcidos a lo largo de aquellos ofrecen denotaciones y connotaciones no siempre de manera explícitas.

${ }^{192}$ Vid. "Más sobre la lectura en el Siglo de Oro", en Florencio Sevilla y Carlos Alvar (eds.), Actas del XIII Congreso de la Asociación Internacional de Hispanistas. Madrid 1988, I, Medieval. Siglos de Oro, p. 518.

${ }^{193}$ Vid. M. Frenk, "Lectores y oidores en el Siglo de Oro", op. cit., p. 49. 


\section{CAPÍTULO II \\ AGUDEZA EN CINCO POÉTICAS ESPAÑOLAS DE LA SEGUNDA MITAD DEL SIGLO XVI Y PRINCIPIOS DEL XVII}

Con base en el "Capítulo I", identifico el término agudeza primero en las tres poéticas dialógicas y posteriormente en las disc ursivas, ya que el método y objetivo que siguen son diferentes. Además, como indiqué, para el análisis aíslo el término en cada una de ellas y lo pongo en diálogo primero con el fragmento en el que se encuentra, luego con el resto del texto y, finalmente, con otras poéticas del corpǔs, siempre que esto sea pertinente. Recuérdese que el objetivo es encontrar indicios significativos sobre cómo conciben la agudeza estos cinco autores.

\section{PoÉTICAS DIALÓGICAS}

Alonso López Pinciano, Philosophia antigva poetica (1596)

La primera poética dialógica que analizo es la Philosophia antigva poetica, conformada por dieciséis epístolas que tratan diferentes aspectos de la poesía: materia, finalidad, géneros, etc. Para desarrollarlos, Pinciano personaje -neófito curioso- conversa con Vgo -médico interesado en la poética- y Fadrique -humanista versado en el ars poetica. Al final de cada epístola, don Gabriel corresponsal de Pinciano personaje- resume los principales puntos tratados en el diálogo y ofrece una sucinta opinión al respecto.

Dentro de estas largas conversaciones, López Pinciano menciona literalmente dieciséis veces el término agudeza. La mayoría de estas pertenecen a la categoría gramatical de adjetivo, en menor medida de adverbio de modo y solo una vez como sustantivo. Además, su presencia no solo es poca, sino que tampoco está distribuida equitativamente en la poética. Por lo tanto, considero que la agudeza en la Philosophia no es esencial para su desarrollo y únicamente connota determinados usos comunes en la España del siglo XVI.

Así, la primera ocasión que se utiliza el término en el diálogo es como adverbio de modo en la "Epistola primera, o introduction a la Philosophia antigua. Trata de la Felicidad humana". Aquí se delimitan las potencias humanas -animales e intelectuales o racionales- entre las cuales se encuentra la imaginación - potencia animal. Esta -a diferencia de la capacidad de los ángeles- no puede obrar por sí misma en el mundo. Vgo cuestiona tal aseveración, porque asegura que va en contra de los refranes: "Si esto es assi, porque el hombre que es poco menos que el Angel, no podra 
hazer algunas actiones semejantes, y dezir que la imaginacion, no haze caso, es contra los refranes: a los quales no sin causa agudamente el Portugues llama Euangelios pequeños" (fols. 23-24).

Hasta el momento no se ha logrado identificar la identidad de este "Portugues" ni cuáles son estos refranes en específico ${ }^{194}$. Sin embargo, no deja de ser significativo que la agudeza está cercana a un género popular breve como los refranes, aunque no se les llama directamente agudos, como sí se considera el acierto del "Portugues" al definirlos "Euangelios pequeños". De una u otra forma, la brěvitās está implicada desde el primer momento con la agudeza pinciana.

Por otro lado, Pinciano cataloga como agudo al "Portugues" por encontrar la relación entre ambos términos. En otras palabras, hay una capacidad, cualidad o potencia que relacionó primero a los refranes con los evangelios - 'verdades divinas'- y luego resaltó el carácter breve de los primeros para crear el sintagma nominal: "Euangelios pequeños". No se dice nada sobre esta capacidad y la forma en la que relaciona ambos términos. No obstante, es posible que se aluda a su cualidad “afilada", capaz de penetrar en la realidad para encontrar tal unión de rēs ajenas entre sí. El eco de la metáfora de Aristóteles es evidente (vid. "Introducción").

Ahora bien, la primera acepción del Tesoro -cualidad "punzante o afilada"- se nota en las características que Vgo da al "apetito sensitivo", otra potencia animal ${ }^{195}$ :

El apetito sensitiuo (dixo Vgo) y [ir]racional ${ }^{196}$, de quie[n] hablamos (assi el co[n]cupiscible, como el irascible) se mueue o por cosas interiores, o por exteriores, como si dixessimos el apetito libidinoso, q[ue] se incita en lo interior por vn estimulo en los mie[m]bros de la generacio[n], nacido de la simie[n]te, o por ser mucha, o por ser ardie[n]te y aguda: y mueuese por lo exterior co[n]vista, tacto y oydo de cosas lasciuas. (f. 31)

El "apetito libidinoso" puede nacer directamente de un impulso fisiológico interno, cuando el semen es ardiente y agudo, o bien punzante. Por supuesto, esto sigue los presupuestos de la sintomatología médica, enraizada en el amor hereos, que basa sus principios en la tradición aristotélica, árabe e islámica ${ }^{197}$. Pese a que esta cita no está relacionada directamente con la producción poética, no deja de ser interesante que agudeza, con su connotación de 'punzante', consigue despertar algo en el ánimo humano.

${ }^{194}$ Ninguno de los editores o críticos de Pinciano agrega una nota a propósito de esta peculiar afirmación. Tampoco su comentador Calero Calero ofrece una explicación para esto, pese a que la coloca como una prueba de la relación existente entre Vives y Pinciano (vid. "La autoría de la Philosophía antigua poética", 375-376).

195 No está de más mencionar que esta descripción de las potencias internas y externas del ser humano sigue una tradición clásica preservada en la $S u d a$, en donde ya existe una capacidad - $\alpha \rho \xi$ ivor $\alpha$, traducida por Joaquín Rodríguez Beltrán como 'sagacidad'- que adquiere "nuevos conocimientos mediante los que ya se posee" (Las fuentes antiguas de la agudeza del ingenio en la retórica renacentista, p. 70).

${ }^{196}$ En el texto dice "racional", pero en las "Erratas" se señala el error: "p.31.1.22.irracional", por lo que indico entre corchetes la corrección.

197 Vid. Marta Haro, "Erotismo y arte amatoria en el discurso médico de la Historia de la donzella Teodor", Revista de Literatura Medieval, V (1993), pp. 113-125 passim. 
La siguiente mención del término se encuentra al final de la "Epistola quarta de las diferencias de Poemas" ${ }^{198}$. En esta ocasión también es un adjetivo aplicado a una empresa ${ }^{199}$ de Garci Sánchez de Badajoz, "la qual ha sido muy loada, y la qual es con cuerpo, casi persona, como dize el señor F[adrique] era el dicho vna figura masculina humana muy fea, co[n] cuernos como cabro[n], y vñas como leo[n], puesto en llamas, dezia la letra: Mas penado, y mas perdido y menos arrepentido" (f. $161)^{200}$. Esta es comparada por Pinciano personaje con la empresa que se encuentra en la "posada del Conde Ioannas Cheueniler Embaxador del Emperador" (f. 160) ${ }^{201}$ y que representa la Victoria. De la empresa de Garci Sánchez dice entonces el neófito curioso que "la inuencion es aguda" (f. 161), pero que, por la "dozella" que representa a la Victoria en la otra empresa, prefería visualmente a esta última. Fadrique agrega al comentario que tal empresa de la posada del Conde es "prouechosa al animo, porque junto con ser de mucho ingenio enseña dotrina moral y diuina, fruto que en las empresas no suelen dar todos arbores" (loc. cit.). Hasta aquí termina la contraposición entre ambas empresas sin que se aclare si existe o no una superioridad entre ellas y por qué, aunque parece que se prefiere la segunda.

Los términos de agudeza e ingenio se aproximan en este fragmento, aunque no se relacionan directamente, sino que, mientras una empresa es de invención aguda, la otra es de mucho ingenio. Ambos términos se refieren a la forma con la cual se crearon las empresas y, como dije, no puede afirmarse la superioridad de una sobre otra, por lo que no puede concluirse tampoco que sea mejor la agudeza que el ingenio o viceversa. Es más, la razón por la cual Pinciano personaje y Fadrique prefieren la empresa de la Victoria es por lo agradable que es a la vista la figura femenina y los atributos doctrinales y morales que se le atribuyen. Sin embargo, ¿estos aspectos son producto del ingenio en estricto sentido? Fadrique afirma: "junto con ser de mucho ingenio enseña dotrina moral y diuina". Es decir, es "junto con" y, por lo tanto, no parece ser una virtud del ingenio este resultado, sino, tal vez, la gracia de la figura femenina. No se especifica, así como tampoco se dice en qué

198 Como comenté al inicio del análisis, la aparición de la agudeza es poco constante en la poética. En consecuencia, no hay indicios de esta en las siguientes epístolas: "Epistola segunda, o prologo de la Philosophia antigua" y "Epistola tercera de la essencia y causas de la Poetica".

${ }^{199}$ Esta es definida como "vna especie de Epigrama Didascalico, porque enseña doctrina moral casi sie[m]pre y podria natural, o lo q[ue] mas quisiere el dueño: el qual no està atado a doctrina alguna, solamente se ata el autor d[e] la Emblema a poner anima y cuerpo en ella, cuerpo es la pintura, y anima la letra q[ue] es sobrepuesta por la qual es ente[n]dida y declarada" (f. 159). Es bastante significativo que los pocos indicios que Pinciano ofrece sobre la empresa la asocien al epigrama y, a su vez, sea uno de los dos ejemplos calificado como agudo. La relación emblema-epigramaagudeza es un hecho, pese a no estar más desarrollada.

200 Dice Julia Castillo, editora de Garci Sánchez: "Con maravilla hemos hallado, en la Philosophia Antigua Poetica de Pinciano, el cuerpo de esta empresa de Garci Sánchez de Badajoz". Se refiere a la que el "conde de Villamediana hizo [con] estas palabras de Garci Sánchez de Badajoz: Mas penado, mas perdido y menos arrepentido, según el propio gusto y la propia intención". Además, con base en Javier Ruiz, la crítica menciona que existe la "noticia de un techo construido entre 1545 y 1550, y decorado con casetones herméticos, uno de los cuales es descrito como el cuerpo y alma de esta empresa" ("Prólogo" al Cancionero de Garci Sánchez de Badajoz, p. 9, n, 1).

${ }^{201}$ Se refiere a la posada donde habitaba el embajador a quien está dirigida la Philosophia, aunque no he encontrado más información a propósito. 
sentido "la inuencion es aguda", así que solo se puede afirmar que es con agudeza o con ingenio que las empresas pueden realizarse. De esta forma, la agudeza vuelve a coincidir con un género poético breve, eco de la tradición que Pinciano retoma y que la relaciona con la brěvǐtās.

Posteriormente, en la "Epistola quinta de la Fabula", López Pinciano comenta el capítulo 16 de la Poética aristotélica, que versa sobre los diferentes tipos de agnición y ejemplifica el mejor tipo de esta con Heliodoro - auctōrĭtās privilegiada en los Siglos de Oro. Este recurre técnicamente a una agnición poco artificiosa; sin embargo, gracias a que "el poeta fue tan agudo, y le hizo tan artificioso que iguala a los demas" (f. 183), se convierte en un modelo de imĭtātĭo. La agudeza, que antes calificaba a la obra, ahora es una cualidad del autor y su papel es preponderante. Es por esta que Heliodoro equiparó la agnición de menor artificio a la de mayor, aquella que es preferible en el ars poetica.

Se vuelve más clara la relación e importancia que la agudeza tiene en la producción poética. Sin embargo, no se ha dado hasta el momento ninguna definición y no se dará como tal en sus siguientes apariciones, porque Alonso López Pinciano no se preocupar por definirla en ningún momento. Como he apuntado, el término connota ciertos usos comunes en la época y, siguiendo la tradición, se le asocia directa o indirectamente a determinados géneros u otros términos. En consecuencia, la agudeza connota otro término importante en la época: el concepto -ya anotado por Fernández-Corugedo ${ }^{202}$. Esta relación representa el desarrollo más importante de la agudeza en la poética dialógica, como explico a continuación.

La "Epistola sexta del Poetico lenguaje" desarrolla la êlŏcūtǐo poética. Que sea aquí donde el médico vallisoletano da mayor atención a la agudeza, explicaría en parte por qué la crítica durante tanto tiempo ha relacionado el término con dichha parte del discurso y no con la inventǐo ${ }^{203}$, como propone Rodríguez Beltrán ${ }^{204}$. Sin embargo, no considero que la agudeza deba restringirse a una u otra parte. De hecho, López Pinciano muestra una agudeza que efectivamente se relaciona

202 Vid. El ingenio desde los Presocráticos hasta Gracián, p. 270-273.

${ }^{203}$ Esto sí ocurre en la primera mención y en la "Epistola quarta" o al menos así se insinúa, lo cual sigue siendo significativo, aún y cuando se traten de alusiones sin mayor explicación.

${ }^{204}$ Vid. op. cit., pp. 13-14. 
principalmente con la èlŏcutť̆o, pero también con la inventǐo ${ }^{205}$, más si consideramos que el concepto del vallisoletano es equivalente al verbum mentis huartiano ${ }^{206}$.

En la conversación, se encuentran a solas Pinciano personaje y Vgo, quien explica al primero:

No fue, no Virgilio falto en los conceptos, sino sumo en todo. Y por que mejor me entendays, digo que ay tres especies de conceptos, vna de graues, otra de agudos, otra de circumflexos; y ni graues, ni agudos y si mas quereys medianos, que del vno, y del otro son hechos ${ }^{207}$. Concepto graue se dize la noticia que el hombre de la cosa concibe, quando es magnifica y alta. Con este genero de concepto fue hecha la Iliada de Homero, y la Eneida de Virgilio, y aun la Baatrachomyomachia del poeta Griego [...] y entre personas no tan altas: tales fueron los de Mingo Rebulgo, el qual con agudas alegorias abaxando la magestad Real [...]. Y en suma el concepto graue es aquel que el ente[n]dimiento forma de la cosa mayor que ella es, y el agudo el q[ue] le forma muchas vezes menor; pero mas sutil y delicado. (fols. 273-274).

Y sobre la ausencia de conceptos agudos en la épica, Vgo agrega que este género tiene

Grandes si, pero agudos muy pocos. Y si queryes saber la causa, acordaos que la epica es imitacion de principes, y grandes señores: y mirad que los principes y señores grandes hablan co[n] grauedad y simplicidad alta: y mirad la gente menor quan aguda es en sus conceptos y dichos, que assi como hienden el pelo hienden la oreja con la agudeza dellos [...], que la necesidad es grande maestra de agudezas y sutilezas [...]. Y aduertid, que el poema heroico deue ser en lenguaje peregrino, y que el concepto agudo en tal lenguaje haria enigmas. (f. 274)

Hay varios aspectos para comentar sobre ambos pasajes. En un primer momento la contraposición entre conceptos graves y conceptos agudos está básicamente definida por el asunto que tratan y cómo en este se juega el estilo. Es decir, el contenido del concepto -magnifico o no tan alto-corresponde a un estilo y a un tipo de ēlǒcūtı̌o -más o menos sencillo y claro. Por supuesto, esto también indica

${ }^{205}$ El excursus etimológico realizado por Rodríguez Beltrán en la tradición grecorromana confirman esto, ya que "tenemos un grupo de vocablos que se acercan mucho a tal concepto pero a través de una clara noción de lo refinado y lo

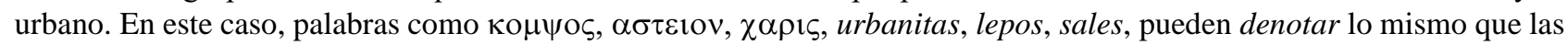
agudezas, esto es, se refiere a los mismo hallazgos verbales-conceptuales desde una perspectiva predominantemente elogiosa, aunque no siempre, pero no connotan lo mismo, pues no provienen de la metáfora de la punta y conllevan una idea de lo elegante y lo propio de un gusto selecto. Sin duda, este primer grupo tiene una fuerte carga estilística, una valoración clara de un modo de expresarse: con ingenio, gracia y propiedad" (id., p. 88). En el caso de Pinciano, se enfatiza el decoro que debe guardar el concepto con el objeto imitado y, por ende, con el género al que pertenece, así como el tipo de público al que va dirigido. Pese a esto, encierra también un hallazgo verbal-conceptual, por lo que es innegable su asociación con la inventǐo, como se verá.

${ }^{206}$ En palabras de Pinciano: "digo del vocablo qua[n]to viene a la consideracion poetica: a cerca de lo qual es de aduertirlo q[ue] Aris. q[ue] como no podemos traer las cosas a las escuelas vsamos de los no[m]bres en vez d[e] las cosas mismas (porq[ue] el no[m]bre es image[n] del co[n]cepto como este d[e] la cosa) [...]; assi el poeta q[ue] supiere bie[n] la naturaleza d[e] la cosa q[ue] trata, la sabra mejor co[n]cebir co[n] el ente[n]dimie[n]to, y segu[n] la image[n] del co[n]cdpto darla el vocablo" (f. 223). A esto, se agrega una paráfrasis del Arte poética horaciana, enriquecida con la teoría de Crátilo, tal y como comenta Fernández-Corugedo: "Nombrado el concepto entremos en materia y en la 'materia', porque cuando trata de esta abandona a Aristóteles y se va por los cerros horacianos y sus cartas socráticas [...]. Pero por medio de esas mismas 'Cartas de Sócrates' enlaza el Pinciano con la teoría del nombre y del concepto en la epístola sexta. Curioso es su razonamiento, porque mezcla la teoría del Crátilo con las cartas sócraticas [sic] de la Epístola, aunque espurio, pues se permite utilizar el término 'pintar', que no existe en la Epístola, en vez del de escribir, y va del concepto en general al concepto poético" (op. cit., p. 270). En breve, el concepto pinciano responde a la materia, al contenido del vocablo poético.

${ }^{207}$ Esta es la única vez que Pinciano hace referencia a los conceptos medianos, los cuales, por inferencia, opino que pertenecen a lo mediocris, siguiendo la Rota Virgili. 
quién lo usa. De tal forma, con respecto a los conceptos agudos, "los principes grandes, que no son della [la necesidad] estimulados, ni inquietados, no tienen para que inuentar estos primores, sino mandar con llaneza y simplicidad, que son compañeras de la verdad" (f. 274). Entonces, los

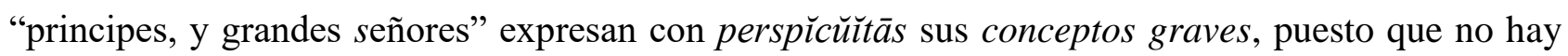
necesidad alguna de hacer lo contrario. En suma, el decoro y el principio de verosimilitud -vital en la poética pinciana- determinan el género al cual pertenecen los dos principales tipos de conceptos: el grave es propio de la épica y el agudo de la lírica. Esto último lo infiero del ejemplo que ofrece Vgo en oposición a los poemas épicos de Homero y Virgilio: las Coplas de Mingo Revulgo. Además, el mismo médico del diálogo lo aclara más adelante.

Con base en lo anterior, me pregunto a qué clase de estilo corresponden los conceptos agudos, ¿a un estilo bajo o medio? La respuesta no es del todo clara, porque de Mingo Revulgo -el único ejemplo dado-solo se dice que es un poco más bajo de los ingenios regios que "con agudas alegorias abaxando la magestad Real". Asimismo, es la "gente menor" la que "aguda es en sus conceptos y dichos". No se puede, por lo tanto, restringir a un solo estilo y, gracias a quienes pueden enunciar los conceptos agudos, considero que pueden pertenecer a ambos. Es claro, empero, que para Vgo es inaceptable su presencia en el estilo alto representado por la épica a causa del lenguaje que esta requiere $^{208}$ : el peregrino.

En cuanto a quién crea y dice cada uno de estos conceptos, comparto la opinión de Sandford Shepard y observo que en esta distinción hay un importante discurso social ${ }^{209}$. Mientras los príncipes y grandes señores usan conceptos graves, sencillos y conceptualmente más cercanos a la verdad, "entre personas no tan altas" (f. 274), se tiene que recurrir a los conceptos agudos para sobrevivir, porque la "necesidad es grande maestra de agudezas y sutilezas" (loc. cit.). La necesidad entonces determina que se haga uso o no de los conceptos agudos, los cuales, además, se expresan en lenguaje peregrino. Razón por la que Vgo ha dicho que el concepto agudo en la épica -género que requiere de claridad- "haria enigmas, como lo fueron las de Mingo Rebulgo, que sin comento se pueden mal entender" (fols. 274-275). En otras palabras, ya que este tipo de concepto requiere en principio del lenguaje peregrino, la épica -que requiere también de este- se volvería incomprensible. Tendería, pues, a la obscūrițās.

${ }^{208} \mathrm{Al}$ entender que el concepto se refiere al verbum mentis, no se puede interpretar el concepto agudo como dicción florida. Por esto, no coincido con la interpretación de Sandford Shepard, que incluso lo restringe al estilo medio o clase media (vid. El Pinciano y las teorías literarias del Siglo de Oro id., p. 74). De hecho, el lenguaje peregrino acompaña a los conceptos agudos. En otras palabras, el concepto es la rēs y la dicción florida o lenguaje peregrino son la verba.

${ }^{209}$ Sandford Shepard no considera los conceptos medianos, pero ve en la distinción de los conceptos un reflejo de la vida en el Renacimiento y cómo esta se encontraba regida por el código cortesano (vid. op. cit., pp. 65-71). 
Lo anterior se comprende mejor a la luz del fragmento 3 de la "Epistola sexta" que establece que el lenguaje peregrino está conformado de tropos retóricos y poéticos. Asimismo, se alerta que su uso puede oscurecer el poema si se agregan conceptos agudos, lo que acercaría peligrosamente la obra a lo que Pinciano llama oscuridad "mala y viciosa" (f. 250). De hecho, las Coplas, poema alegórico, necesitan un comentario para volverse claras. Esto dice mucho acerca de cómo el concepto agudo es ya oscuro por sí mismo.

Cabe entonces preguntarse cuán presente está en Pinciano la idea de la "asimetría o desfase entre lenguaje y pensamiento" que define Rodríguez Beltrán como "agudeza del ingenio"210. Por mi parte, opino como Fernández-Corugedo que solo podemos suponer qué es lo que quiere decir el vallisoletano con ambos tipos de conceptos $^{211}$. Sin embargo, considero que sí se puede establecer que el concepto agudo, al ser creado por la necesidad de los humildes, se acerca a lo cómico y a la brevedad del epigrama ${ }^{212}$. Y sobre esto último afirma Vgo:

si Virgilio escriuio con suma perfeccion heroyca, y imitò a principes y semideos, claro es que no tenia para que vsar de conceptos agudos, sino graues, y seueros, vrbanos, y cortesanos. Siga pues, co[n]uiene, cada poeta su aduocacion; y ni el tragico, ni el epico tengan co[n]ceptos muy agudos: ni el comico, o lirico, o epigramatico graues; sino q[ue] assi como en las palabras, sea en los co[n]ceptos imitador de todo genero de persona. (f. 275)

Así pues, el concepto grave y el concepto agudo son producto de un proceso inventivo, en el que influye significativamente la necesidad del individuo que lo crea y depende de las reglas del decoro de los géneros poéticos, como enfatiza Vgo. La épica requiere conceptos graves, mientras que la lírica, el epigrama y lo cómico dependen de los agudos.

Con los géneros enlistados, además, la agudeza se relaciona nuevamente con la brěvittās, al mencionar al epigrama, género agudo por excelencia ${ }^{213}$. Por otra parte, se adscribe a lo cómico y se

210 "La agudeza del ingenio implica, pues, una asimetría o desfase entre lenguaje y pensamiento: se accede a lo hondo del sentido mediante los recubrimientos formales y estilísticos, pero éstos no conducen a lo profundo de manera directa y llana, como si fuera el reflejo exacto de lo expresado. La forma, por así decirlo, siempre es menos que el fondo. El ideal es, con poco, decir mucho" (op. cit., p. 14).

211 "El concepto grave, conjeturamos, hace referencia a la $\gamma \nu \omega \mu \eta$, o quizá a la $\delta 1 \alpha v o r \alpha$ como conjunto total del significado en Aristóteles o el de sentido (sensus) total de Quintiliano [...] a juzgar por los ejemplos que se dan [...]. En suma, el concepto grave es aquel que 'el entendimiento forma de la cosa mayor que ella es' (207).

Por su parte el concepto agudo, conjeturamos de nuevo, hace referencia al concepto lírico y es el que el entendimiento 'forma muchas veces menor, pero más sutil y delicado' (id.)” (op. cit., p. 271, el número que se encuentra entre paréntesis dentro de la cita corresponde a la edición de la Philosophia usada por Fernández-Corugedo).

${ }^{212}$ En el ladillo del folio 274, se lee “Iиuen. Sat. 3". La referencia identifica al poeta a quien Pinciano personaje recuerda: "Ya me parece que lo voy entendiendo, y me acuerdo del poeta que dixo del Greguezillo hambriento, buela ta[n]to que suben sus ingenios hasta el cielo" (f. 274). El neófito curioso comprende que la necesidad es imprescindible para la creación de conceptos agudos y su auctōrìtās para ejemplificarlo es Juvenal, cuyas Sátiras fueron un punto de referencia para el género cómico en la época. Además, me parece muy significativo que sea esta necesidad la que provoca el vuelo del ingenio. Una vez más agudeza e ingenio tienen un punto de encuentro, pero sin mayor desarrollo.

${ }^{213}$ Vid. Mercedes Blanco, Les Rhétoriques de la Pointe. Baltasar Gracián et le Conceptisme en Europe, pp. $17-$ 19. Rodríguez Beltrán comenta también al respecto que "lo crucial son los tratados que comenzaron a aparecer en la época para teorizar sobre este género menor. De manera casi invariable, tales tratados hablarán de la agudeza como 'el alma del epigrama"” (op. cit., 24; la frase "el alma del epigrama” pertenece a Pierre Laurens, tal y como lo indica Rodríguez). 
reafirma su importancia en la lírica, en donde toma el lugar de la fábula del género dramático. Así, el decoro debe existir entre la persona que inventa el concepto -a su vez objeto de imitación poética- y resto de la obra: el tipo de concepto, el lenguaje poético que este requiere y el género al cual pertenece. Todo esto también indica el público ideal de la obra poética ${ }^{214}$.

Ahora bien, este decoro tan rigurosamente guardado es estipulado por Vgo, cuyo ingenio no iguala al de Fadrique, pese a equiparársele. Esto mismo lo afirma don Gabriel, cuya voz al final de cada epístola posee la misma autoridad que la de Fadrique en el diálogo, y, con esta, disiente de $\mathrm{Vgo}^{215}$ :

Veo que se desculpa con la dificultad de los poner en numero cierto [a los conceptos], mas con todo entiendo del ingenio de Fadrique, q[ue] si ahi se hallara, hablara en ello con vn poco de mas cuydado, y nos dixera algunas cosas nueuas, sutiles, y vtiles: y que fuera de parecer, que como el metro no parece mal a todo genero de gentes, aunque contradiga a la buena imitacion; assi el concepto agudo en qualquier estado, o estilo parece bien, y da mucho deleyte y gusto. (f. 279)

Don Gabriel no se interesa por los conceptos graves ni medianos, sino que se pronuncia sobre el uso de los conceptos agudos, los cuales son oportunos en cualquier género poético, porque estos son agradables al espectador. Para don Gabriel, entonces, el deleite es más importante que la excelencia de la imitación, es decir, privilegia el dèlectāre como causa final de la poesía.

Con tal precisión, confirmo que el concepto agudo está determinado por la necesidad, se asocia con la brěvitāas, es cercano a lo cómico y a la lírica, y, por el deleite que causa, puede estar presente en todo género poético. Sin embargo, sobre esto último don Gabriel no deja en claro cómo se tendría que manejar el lenguaje peregrino que requiere este tipo de concepto y cómo evitar entonces que se vuelva enigma. La cuestión, pese a los deseos de este y del lector, queda sin dilucidar y solo se reafirma la agudeza como tipo de concepto en la "Epistola septima del metro", donde López Pinciano agrega además una valiosa consideración.

${ }^{214}$ No en vano Pinciano advierte a su noble destinatario, el conde de Khevenhüller, embajador imperial de Austria en Madrid: "Otro si, suplico a V.S. si algun dia hiziere a esta obra digna de sus oydos, los abstenga de la epistola nona, y especialmente del fragmento quarto della, cuya materia es ridicula, y mas co[n]uenietne a orejas populares y comicas, que no a las patricias y tragicas, quales ser deuen las de los Principes y grandes señores, y quales son las de V.S. [et]c." (“Al conde Ihoanes Kevenhiler de Aichelberg”, s. f.).

${ }^{215}$ El investigador François Lopez hace una importante distinción entre el grado de autoridad de las voces que componen el diálogo humanista de la Philosophia. Así, "para que lo dispuesto no se perciba con demasiada nitidez, la doctrina y el talento argumentativo de Fadrique están en ocasiones casi igualados por los que ostenta Ugo, el médico poeta, excelente expositor que tiene sus defectos y debilidades" ("Sobre la moderna filosofía poética de Alonso López Pinciano", en Christophe Couderc y Benoit, «Por discreto y por amigo». Mélanges offerts à Jean Canavaggio, p. 580). Sin embargo, es innegable que "se establece una jerarquía de autoridades, no sólo en cuanto a rango social, siendo éste bien marcado en nombres y tratamientos, sino en cuanto concierne la inteligencia, el saber y la posesión de la verdad, cosas que vienen dominadas en distintos planos por Fadrique y por don Gabriel. El corresponsal del Pinciano está habilitado para condensar en claras y apretadas síntesis lo que se le comunica y somete" (id., p. 580). Por lo tanto, pese a que la naturaleza de esta investigación impide la posibilidad de negar una u otra posición, sí es importante en ciertos momentos considerar dicha jerarquía, que permite acercarnos más a las reflexiones hechas por el ecléctico autor. 
Cuando Fadrique enuncia la clasificación de los diferentes tipos de metro y cómo deben ajustarse a los géneros poéticos, se acusa al personaje de Pinciano de interpretar con poca agudeza algunos postulados sobre el metro de la sátira. Hecho que demuestra que la agudeza no es solo necesaria para la creación sino también para la interpretación ${ }^{216}$. Además, tanto Fadrique como don Gabriel, las voces más autorizadas de la poética, observan que el metro del epigrama dependerá del tipo de concepto, sea este largo, mediano o breve, que "es lo mas ordinario" (f. 320). Por esto, la brěvitāas, si bien no es obligatoria, sí es lo más acorde a la tradición del género.

Con base en esto, Fadrique ilustra el metro del epigrama con el siguiente concepto: "vn poeta formò de dos niños hermanos muy hermosos; el vno de los quales era varon, y el otro hembra; esta falta del ojo siniestro, y aquel del diestro" (f. 320). Este, "concepto agudo que a mi parecer lo fue" (f. 321), es una adaptación libre de un epigrama atribuido a Marcial -“el poeta Latino" (f. 320) ${ }^{217}$ - que López Pinciano hace en una octava -“dos distichos exametros y pentametros” (loc. cit.):

Falto es Achon del diestro, y del siniestro

Ojo Leonela està su hermana bella, y a buen juyzio de pintor maestro hermosissimo es el, bellissima ella, niño bello a quien falta el ojo diestro da essotro con que vees a la donzella, y quedareys el vno y otro luego, ella Venus hermosa, y tu amor ciego. (fols. 320-321)

Agrega Fadrique que mucho "mejor està en Latin, pero para exemplo de lo que digo basta assi" (f. 321), para resaltar la brěvĭtās del género, esencial para la agudeza. De esta forma, el concepto agudo se resuelve con una referencia mitológica y con una metonimia que va de lo particular a lo universal, de Achon y Leonela a Cupido y Venus. Además, es indudable que la comparación entre un par de seres humanos y divinidades, aunada a lo que se le solicita al niño -quitarse el ojo que tiene para darlo a la hermana-, pertenece a lo cómico.

Asimismo, el tipo de concepto determina la formulación de este género breve y su resultado. La agudeza está implicada tanto en la rēs -el concepto mismo- como en la verba -brěvitās - del epigrama y, por tanto, presente en la invenť̌o y la èlǒcūť̌o. López Pinciano no da más particularidades o ejemplos sobre dicho concepto, pero sí retoma la agudeza para adjetivar a un tipo de dicho propio del estilo cómico, lo que arroja más luz a propósito del término.

216 "F[adrique] respo[n]dio: Vos me aueys interpretado mas piadosamente, y menos agudame[n]te q[ue] yo lo entiendo" (f. 318).

217 Según Fernando García Romero, mismo que advierte sobre la posible no autoría de Marcial, el poema corresponde al epigrama "Lusce puer, luscae lumen concede Parenti, / Sic tu caecus Amor; sic erit illa Venus", del cual hay varias traducciones recopiladas en un manuscrito descrito por el investigador: "MARCIAL / Epigramm. / EN / Castellano / M.S. / 52". Este contiene también la traducción de Manuel Salinas, que aparece significativamente en el "Discurso XV" de Agudeza y arte de ingenio (vid. "Una traducción inédita de Marcial", MYRTIA. Revista de Filología Clásica de la Universidad de Murcia, año 2, vol. 2 (1987), pp. 50-51). 
No se menciona a la agudeza en la epístola dedicada a la tragedia-como indica el decoro. Sin embargo, en la "Epistola nona de la Comedia", Fadrique afirma primero: "lo vrbano dicho, y lo venusto, que ansi dize[n] los dichos y hechos cotesanos y discretos y agudos, que no producen risa: tratemos de solos aquellos que la crian, y fueron dichos salados de algunos" (f. 386). Y, más adelante, aconseja que "el que dize la palabra ridicula, deue quedar mesurado para hazerla mas risueña: y que de las palabras vnas son vrbanas y discretas, que sin perjuyzio de nadie notable dan materia de risa" (f. 393). Finalmente, recupera de la retórica el tratamiento de la quaestĭo y cómo esta puede desarrollarse de lo particular a lo universal -Pinciano especifica que es del "menor a mayor" (f. 395)y da como ejemplo de esta "palabra ridicula" una historia del cardenal Cisneros. Según el relato, el cardenal, encolerizado con un litigante que pedía un juez más de Madrid para un pleito, respondió: "Que hombre puede auer en Madrid que pueda ser acompañado de mi juez. Aqui el litigante encolerizo, y dixo: Cuerpo de Dios conmigo, pudo dar Tordelaguna a vn hombre para Arçobispo de Toledo, y Madrid no puede darle para aco[m]pado del Vicaro de Alcala" (loc. cit.). En este caso, el cardenal Cisneros, oriundo de Torrelaguna, abre la posibilidad de que cualquiera en Madrid puede acompañar en el pleito al vicario de Alcalá. Su comparación "es de la especie de los agudos y discretos" (loc. cit.).

Con base en lo anterior, los dichos agudos se equiparan a los cortesanos y discretos, y están en contraposición con los salados. Por lo tanto, provocan una risa moderada que no daña, a saber, la risa eutrapélica aristotélica -como la que provoca la historia del cardenal Cisneros-, la cual para el género cómico pueden tener "poco efecto cómico" 218 . Esto se reafirma cuando se describe lo ridículo de la alegoría, "junta de metaforas" (f. 400) - u "otra anima del anima" (f. 467) ${ }^{219}$ - y se ofrece un ejemplo poco risueño ${ }^{220}$. Sin embargo, aquí se pierde la equivalencia entre lo cortesano, lo discreto y lo agudo, y se pone una distancia entre ellos, como de cierta forma ya había pasado con la clasificación de los conceptos. Comenta Fadrique de la historia enunciada: "Esta tampoco es muy

\footnotetext{
${ }^{218}$ Vid. Margarete Newels, Los géneros dramáticos en las poéticas del siglo de oro. Investigación preliminar al estudio de la teoría dramática en el siglo de oro, pp. 92-93.

${ }^{219}$ Pinciano entonces se refiere a la alegoría épica, porque "la que era antes anima, que era el argumento, queda hecho cuerpo y materia debaxo de quie[n] se encierra y esconde la otra anima mas perfecta y esencial, dicha alegoria" (f. 467). Como señala Fernández-Corugedo, Pinciano, a través de Gabriel, ya había dado una definición similar sobre la alegoría (vid. f. 163), a la que, además, se le da un valor doctrinario (vid. f. 212). Por tal motivo, para el doctor de la Universidad de Estocolmo, la alegoría pinciana se acerca al concepto graciano, porque es "la materia sobre la que acaece otra fábula, otro argumento, la esencia del poema. Esto es exactamente lo que dirá Gracián del concepto en relación con la figura poéticas [sic], cita que hemos repetido ya varias veces, y que extenderá al gran concepto: la alegoría" (op. cit., p. 273). Si consideramos lo enunciado sobre el concepto como verbum mentis, es cierto que ambos términos se aproximan entre sí, pero no considero que puedan ser equivalentes, por el simple hecho de que la alegoría es precisamente una suma de metáforas y el concepto es una idea. Lo cierto es que, con respecto a lo que dice Fernández-Corugedo, sí hay una relación entre las equivalencias de la alegoría épica pinciana y el concepto de Gracián con respecto a las figuras retóricas. Sin embargo, no me parece que alegoría y concepto puedan ser entendidos de la misma forma, al menos a partir de lo poco que se nos dice en la Philosophia.

220 "Sigue en orden la alegoria, la qual es junta de metaphoras y de la qual sea exemplo Ciceron, que dixo de Celio Orador, que tenia mejor siniestra, q[ue] diestra; porque sabia mejor acusar, que defender" (f. 400).
} 
ridicula, porque tiene poco de lo feo y torpe; que ado[n]de no ay dicacidad, digo murmuracion, o fealdad de palabra, o ignorancia y simpleza, el dicho agudo queda vrbano y cortesano, mas poco ridiculo" (f. 400). En otras palabras, como lo explica Newels, el dicho agudo que carece de la fórmula ciceroniana turpitudo et deformitas solo puede volverse urbano y cortesano, creando así dos estilos cómicos: uno propio para la corte y el otro no apto para esta ${ }^{221}$.

Me parece pertinente ahora preguntar si los dichos agudos dejan de ser tales para volverse urbanos y cortesanos o son losos últimos un tipo de los primeros. De ser el primer caso, el dicho agudo, pese a lo anterior, se asemeja al concepto agudo y es más afín a la comedia, mientras que los dichos urbanos y cortesanos, al ser menos ridículos, crearían una comedia propia de la corte, como su mismo nombre indica. Por el contrario, si el dicho agudo es solo un poco más ridículo que los otros dos, no dejaría de pertenecer a una categoría que podría llamarse "ridículo moderado", aunque tampoco lo alejaría en su totalidad del concepto agudo, que es concebido también por "personas no tan altas" (f. 274).

Como ya ocurrió con el concepto agudo, la cuestión no queda zanjada, lo que no impide ver el aspecto positivo bajo el cual Pinciano tenía a la agudeza, pues cuando se habla de la cantidad de actos que debe tener una comedia y de cómo se ha pasado de tres actos a cinco, se recurre al tópico de aurea aetas. Fadrique, la voz autorizada, afirma que "los hombres de aquellos tiempos andauan mas listos y agudos en el camino de la virtud; y assi el tiempo que entonces bastò, agor no basta" (f. 415). La agudeza es necesaria para profundizar algunos aspectos de la realidad, así como para la creación de algunos conceptos y dichos, y de una especie poética especial: el epigrama.

En la "Epistola doze de las seys especies menores de la Poetica"222, Vgo define el epigrama y asegura que "pide este poema suma breuedad, y agudeza suma, porque no las teniendo, queda muy desabrido y enfadoso; que el concepto si es largo, cansa; y si boto, hiere como mazo" (f. 509). La forma en que brěvitâs y agudeza se entrecruzan nuevamente y se definen como la esencia del epigrama ${ }^{223}$ reafirma aspectos que están implicados desde la primera mención. Además, es la primera vez que agudeza se sustantiva en la Philosophia y determina una cualidad que debe poseer para evitar que el epigrama sea como golpe violento ${ }^{224}$ o bien "enfadoso". Considerando también lo que se ha

${ }^{221}$ Vid. op. cit., pp. 91-93.

${ }^{222} \mathrm{La}$ "Epistola decima de la especie de Poetica dicha Dithirambica", la "Epistola vndecima de la heroyca" y la "Epistola treze y vltima de los actores y representantes" no poseen ninguna mención del término analizado.

${ }^{223}$ De aquí que se afirme más adelante: “después tomo el no[m]bre mismo de epigrama qualquier otro poema que le pareciesse en lo breue y agudo sin que fuesse sobre escrito en parte alguna" (f. 509).

224 "Echar ò arrojar fuera de algun lugár lo que estaba dentro, y con violéncia. Es formado del nombre Bote en significación de empellón con violéncia, y tiene yá poco uso, excepto en Galicia. Lat. Evellere. Extrudere. NEBRIX. Chron. de los Reyes Cath. cap. 58. fol. 230. Dos dientes que le havían botado de la boca. MEN. Copl. 177. Y botan los otros que no son tamáños" (Diccionario de la lengua castellana, en que se explica el verdadero sentido de las voces, su naturaleza y calidad, con las phrases o modos de hablar, los proverbios o refranes, y otras convenientes al uso de la lengua, s. v. violento. Disponible en línea: http://web.frl.es/DA.html). 
dicho de los conceptos y los dichos, opino que la agudeza para Pinciano es una cualidad que vuelve agradable -mas no siempre graciosa- a la poesía, y puede pertenecer tanto al ámbito de la inventio (conceptos y epigrama), como al de la ēlŏcūtĭo (dichos). Asimismo, es también una cualidad valiosa, "punzante", que ayuda a comprender y penetrar en la realidad para extraer una verdad -de aquí que se afiance su relación con la inventǐo.

En suma, López Pinciano no define el término de agudeza, pero usa connotaciones ya tradicionales de esta -su carácter "afilado", por ejemplo- para adjetivar algunos elementos de la poesía - conceptos y dichos-o para caracterizar un género poético -el epigrama. De la misma forma, se le asocia a la brěvittās, sin que pueda afirmarse que esta sea una característica de la agudeza o no; simplemente se les asocia constantemente. Finalmente, la agudeza tiene importantes implicaciones en lo cómico, principalmente porque es producto de la necesidad -no se sabe si siempre es así- que viven individuos bajos y cómicos, en tanto no son príncipes o reyes -caracteres propios de la épica y la tragedia. Por lo tanto, me parece que en la Philosophia la agudeza es una forma de hacer o percibir algunos elementos poéticos, aún y cuando está sustantivada.

\section{Luis Alfonso de Carvallo, Cisne de Apolo (1602)}

La segunda poética dialógica que analizo es el Cisne de Apolo. Como la Philosophia, es un diálogo humanista, conformado por cuatro diálogos, donde el personaje alegórico de la Lectura instruye a Carvallo personaje en el arte poética y refuta a Zoylo, que representa la opinión del vulgo, de aquellos detractores del arte discutido en las conversaciones: el arte poética. Cada diálogo está dividido en $\operatorname{apartados}^{225}$ rematados con una octava que sintetiza lo más importante. En este contexto, la agudeza, como adjetivo, es empleada diecisiete veces a lo largo del Cisne. De estas, cinco están calificando el sustantivo ingenio. Hecho sintomático porque el sintagma ingenio agudo ya está presente en las definiciones de los diccionarios de la época y en el minucioso tratado de Huarte de San Juan (vid. “Introducción”).

Observo además que existen otros adjetivos que se utilizan casi a la par de agudeza: sutil o bien sutileza y delicado o delicadeza. El primero de estos es considerado en el Tesoro de Covarrubias como sinónimo de agudeza, de la misma forma que lo hace la Real Academia (1739), misma que lo identifica como una característica del ingenio (vid. "Introducción”). Además, se lee en el tomo VI del Diccionario de la lengua castellana, en la segunda acepción de sutil: "Vale tambien agudo, perspicaz, é ingenioso. Latin. Subtilis. Acutus. CALIST. Y MELIB. F. 21, Gózome, Parmeno, que hayas

${ }^{225}$ El número de estos depende de la extensión del diálogo. De esta forma, el "Dialogo Primero" se divide en catorce apartados, el segundo en dieciocho, el tercero en veintiséis y el último en dieciséis. 
limpiado las turbias telas de tus ojos, y respondido al conocimiento, discrecion, y ingenio sotil de tu padre"226. Mientras que la segunda acepción de sutileza afirma que

Metaphoricamente significa la perspicacia de ingenio, ó agudeza. Aplicase tambien al instinto de los animales. Lat. Subtilitas. Acumen. ARGOT. Monter: cap. 6. Cá son muchas las sotilézas de los animales, è debe deparar las ardidezas, que debe usar contra ellas. PUENT. Conven. lib. 2. cap. 25. §. 9. Toda está llena de sutilezas, y primores del amor de Dios, y del próximo. ${ }^{227}$

Por otro lado, delicado en el Tesoro hace un envío a delgado: "se dixo de delicado, oponese a grossero, o gordo. Algunas vezes vale sutil e ingenioso" 228 . De manera similar se registra en la quinta acepción del Diccionario de Autoridades: "Metaphoricamente vale lo mismo que sutil, agudo, delgado y ingenioso" 229 . Además, es frecuente en el Examen de ingenios que ambos términos -al mismo tiempo o no- adjetiven al ingenio.

Con base en esto, la relación entre agudeza, sutileza y delicado está presente en el Cisne desde el principio cuando advierte "A los discretos poetas el Auctor": "Soberuia fuera grande mia, querer sujetar los delicadissimos ingenios Vs. mercedes a reglas y preceptos mios, queriendo poner limitacion, y orden, a la subtileza de las obras, que tanto a toda arte exceden” (f. $\uparrow \uparrow$ r). Conservando el latinismo ${ }^{230}$, Carvallo adjetiva las obras de los poetas, hechas con sus delicadísimos ingenios -lo que recuerda la causa eficiente de Pinciano (vid. "Capítulo III").

Ahora bien, sintácticamente hablando, el jesuita no se atreve a poner "limitacion, y orden" a la "subtileza de las obras" y no tanto a sus ingenios. Por tanto, subtileza es sinónimo de agudeza y no de ingenio. Sin embargo, me parece que podría identificarse también con ingenio, de manera que subtileza, ingenio y agudeza estarían semánticamente relacionados. La consideración la hago con base en la commŏrātı̌o -figură sententiă por adiectĭo-, que coloca como sintagmas equivalentes "sujetar los delicadissimos ingenios" y "poner limitacion, y orden, a la subtileza de las obras". Se debe, empero, hacer una precisión, porque la relación no es entre los sustantivos, sino entre adjetivos. Es decir, así como lo considera poco más de un siglo después la Real Academia -“perspicacia de ingenio"-, Carvallo se refiere a una característica del ingenio: “delicadissimo”, sotil-como Rojas lo

${ }^{226}$ Diccionario de la lengua castellana, en que se explica el verdadero sentido de las voces, su naturaleza y calidad, con las phrases o modos de hablar, los proverbios o refranes, y otras convenientes al uso de la lengua, s. v. sutil (disponible en línea: http://web.frl.es/DA.html).

${ }^{227}$ Id., s. v. sutileza.

${ }^{228}$ Sebastián de Covarrubias Horozco, Tesoro de la lengva castellana, o española, s. v. delgado (disponible en línea: http://fondosdigitales.us.es/fondos/libros/765/descargar/tesoro-de-la-lengua-castellana-o-espanola/).

${ }^{229}$ Diccionario de la lengua castellana..., s. v. delicado.

${ }^{230}$ El Diccionario de la lengua castellana consigna en la primera acepción de sutil: "Es tomado del Latino Subilis, por lo que se debia escribir con la $b$; pero para suavizar la pronunciacion, se le ha quitado; aunque algunos suelen escribirle con ella, y antiguamente decía sotil" (id., s. v. sutil). Aunque no es posible asegurar cómo era la lectura vocalizada de un texto como el Cisne, me parece reveladora la afirmación de la Real Academia, porque hace hincapié en cómo el medio escrito ("suelen escribirle") facilitó que Carvallo se acercara a la tradición grecolatina -rescatada y preservada filológicamente por los humanistas- a través de gestos tan significativos como la conservación de la grafía latina. 
emplea en la Celestina- o agudo, y crea así un tipo específico de ingenio. Este, además, se relaciona con la producción poética puesto que crea la "subtileza de las obras".

Entonces, si el ingenio es sutil o agudo, la creación tendrá las mismas características, las cuales, me gustaría anotar, están en perfecta sintonía con la "metáfora de la punta" descrita por Joaquín Rodríguez Beltrán. Tal metáfora parte de la acepción de agudo como filoso, "base sobre la que se articula el concepto de agudeza: es preciso afilar la cuña o punta del ingenio para penetrar en esos significados ocultos" ${ }^{231}$. La sutileza se volverá el adjetivo que describe una obra que ha sido concebida con ayuda de un determinado tipo de ingenio ${ }^{232}$, ese que es “afilado". Además, la sutileza junto a la elegancia y lo artificioso son las cualidades prescritas para la obra artística ${ }^{233}$ y, aún más, para el lenguaje poético.

La "metáfora de la punta" se refuerza con la primera mención literal de agudeza, la cual adjetiva a los poetas. Dichos no pertenecen a una "casa, familia, ni descende[n]cia, sino cierta Seta, Professio[n], ò Facultad, de hombres agudissimos" (fols. 4v-5r). Las tres formas con las que se designa al "gremio" de los poetas determina un aspecto fundamental de la poética de Carvallo: la dualidad horaciana arte-ingenio enriquecida con la tradición neoplatónica. Observo pues que el furor e ingenio -no equiparables entre sí- están presentes en la "Seta" y "Facultad", mientras que el arte está en los tres: "Seta", "Professio[n]" y "Facultad".

El tópico, pese a variar ligeramente el tradicional arte-ingenio, pone al Cisne como un epílogo tardío de una de las discusiones poéticas más importantes del siglo $\mathrm{XV}^{234}$. De hecho, la presencia de este tópico se explica solo si "Seta", "Professio[n]" y "Facultad" son leídos como amfilogías que, empero, están perfectamente circunscritas en un determinado contexto, para evitar cualquier

${ }^{231}$ Las fuentes antiguas de la agudeza del ingenio en la retórica renacentista, p. 14.

${ }^{232}$ Esto se analizará con más detalle en el apartado de Carvallo del "Capítulo III". Sin embargo, no quiero dejar de anotar ahora que la sutileza califica tanto la obra y el tipo de ingenio que la crea, como otras capacidades del poeta. Por ejemplo, así se le considera al tipo de entendimiento que posee San Juan el Evangelista. Él "es comparado a la Aguila, y se la dan como por su insignia, sino por los altos misterios, a que dio alcance con su entenimie[n]to subtilissimo" (f. $14 \mathrm{v})$. La sutileza -y se puede agregar la agudeza- parece por tanto ser fundamental no solo para el poeta, sino también para el profeta, ya que determina esa cualidad "puntiaguda" con la cual se penetra en la realidad y se va entonces más allá -algo aludido también en la Philosophia. Además, así como la obra del ingenio sutil es calificada con esta cualidad, el producto del entendimiento -el pensamiento - también es "sutil y delicado" (f. 197v) cuando, junto al resto de las capacidades poéticas, es presa del furor y sufre un "sotil embeleco" (loc. cit.).

233 De tal forma se lee en el poema didáctico que precede el "Dialogo primero": "A mi Nimpha pregunto la Lectura, / (q[ue] este es el no[m]bre de mi Nimfa hermosa,) / Lo que significaua la escultura / elegante, sutil, y artificiosa, / del Cisne, que al armiño en su bla[n]cura / vence con gran excesso alla graciosa / à mis dudas assi fue respondiendo, / y yo como ignorante proponiendo" (fols. $3 \mathrm{v}-4 \mathrm{r}$ ).

${ }^{234}$ Sobre este aspecto de la tópica mayor horaciana, Antonio García Berrio comenta: "no es que en todos estos tratados del siglo XV faltara la ocasión de hacer entrar a Horacio, pues, al debatirse en todos ellos la dignidad de la poesía, se invoca con frecuencia la alta índole de la creación, materia en la que, como bien sabemos, el recuerdo de la dualidad ingenio-arte acuñada insuperablemente por Horacio era ya tópico obligado" (Formación de la teoría literaria moderna, 2, Teoría poética del Siglo de Oro, p. 22. A esto se agregue el desarrollo completo de la relación entre arte e ingenio, a la que García Berrio dedica en el tomo 1 de la Formación, pp. 237-311). El Cisne responde también a esta necesidad de abogar por la dignidad de la poesía, puesto que la defiende de los prejuicios injustificados del vulgo, representado por Zoylo. 
malinterpretación. En principio, "Seta”, arcaísmo de "secta”, podía significar "doctrina, máxima, ù opinión particular enseñada por algun Maestro célebre, que la halló, ú explicó, y otros la siguen y defienden". Pero también es “errór, ù falsa Religión, diversa, ò separada de la verdadera y Cathólica Christiana enseñanza por algun Maestro famoso: como la Secta de Lutéro, Calvino, Mahoma"235.

Carvallo, profesor jesuita, en ningún momento ve a la poesía como una religión, por lo que es evidente que piensa la "Seta" como doctrina dictada -importante recalcar-por una auctōrĭtās ${ }^{236}$, alejándola de la crítica del vulgo que veía en la poesía un efecto pernicioso para la sociedad. Sin embargo, considero que no es casualidad que el tratadista haya usado tal vocablo, porque así alude una capacidad casi profética por parte del poeta, colocándolo en un nivel místico y religioso. De aquí también que lea la compenetración del tópico horaciano con la teoría platónica de los furores.

Por supuesto, para evitar que se vea a la poesía como "errór, ù falsa Religión”, no deja de aunar a "Seta" los conceptos de "Professio[n]" y "Facultad". De esta manera se clara que el valor que se quiere rescatar es el doctrinal y, asimismo, justifica la creación de las poéticas como el Cisne con el siguiente razonamiento: la poesía depende de un don natural, pero no significa que este no requiera del stŭdı̆um ${ }^{237}$ de las auctoritates clásicas y modernas. En otras palabras, Carvallo, al preponderar el carácter doctrinal del grupo conformado por los poetas, está propugnando por la educación -el "afilamiento", siguiendo con la "metáfora de la punta"- del ingenio, o bien de la facultad encargada de la creación poética.

Con base en lo anterior, se entiende que "Facultad", además de ser leída en su cuarta acepción -“conjunto de los Doctores o Maestros de alguna ciencia"-, continúa implicando la "Poténcia o virtud de hacer alguna cosa"238. Los poetas, entonces, son un grupo de doctores que han estudiado todo lo referente al arte poética (ciencia) y por ello son "hombres agudissimos", en tanto han afilado y adoctrinado su facultad nata, el ingenio. De ser así, agudeza sería el resultado del estudio y del arte poética, siempre y cuando se considere el campo semántico doctrinal en que se encuentra inserto tal adjetivo.

No obstante, en esta mención en particular, agudo no califica al ingenio -como sí lo hace con frecuencia más adelante-, sino al tipo de hombre que es el poeta. Por lo tanto, puede significar

${ }^{235}$ Diccionario de la lengua castellana..., s. v. secta.

${ }^{236}$ En el Cisne, la auctôrĭtās, que encierra en sí varias auctoritates, está representada indiscutiblemente por la voz de Lectura, contrapunto de Zoylo, el vulgo, y será apoyada por la voz ficcional del autor, Carvallo. De tal guisa, considero que la poética del jesuita sí pretende afirmarse como auctōrittās doctrinal que ayude a guiar el agudo ingenio de los poetas.

${ }^{237}$ Quiero advertir desde ahora que durante el análisis considero pertinente privilegiar el uso del término en latín stŭdı̆um al de estudio, para acercar más al lector a la denotación clásica y humanista de la palabra, tan presente en la España de los siglos XVI y XVII. Así, quiero recordar que una parte importante del currǐcŭlum de los studia humanitatis establecía la lectura, traducción y comentario de los textos clásicos, aspecto fundamental en las poéticas analizadas para

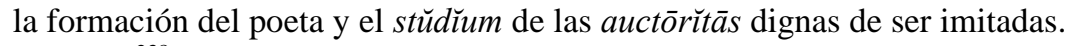

${ }^{238}$ Id., s. v. facultad. 
también la cualidad inherente de este, misma que lo diferencia del resto de los hombres. La agudeza superlativa lo vuelve superior al promedio y lo acerca a la divinidad. ¿Esta, entonces, será una característica del ingenio o del ser humano que lo acerca a lo divino? Por el resto de menciones me inclino a suponer desde ahora que se trata del ingenio, sin embargo, este, al ser una capacidad humana, vuelve agudo por extensión al individuo. Así, el Cisne se acercaría al pensamiento barroco del tratadista italiano Emanuele Tesauro, quien sostiene a mediados del siglo XVII: la argutezza es "Vn diuin Parto dell'Ingegno"239.

Después del exordǐum, la agudeza deja de designar al tipo de ser humano que es el poeta y se vuelve el adjetivo preferido de Carvallo para designar un tipo de ingenio. Así aparece por primera vez en la octava que sintetiza §. 1., "Que cosa es Poesia de su insignia, y armas", del "Dialogo primero de la definicion invencion, y materia dela Poesia, [et]c":
Por el Cisne el Poeta es entendido,
$y$ hazedor significa propriamente
el que de furor siendo mouido
con claro ingenio agudo, y excelente,
en elegante verso ha referido
cosas mayores que la humana gente. (f. 6r)

Hay tres características del ingenio que poseen los creadores poéticos: claro, agudo y excelente. De estas depende que el ingenio, aunado al furor-que es "diuinio" (loc. cit.)-, cree el "elegante verso", superando así a la "humana gente".

Por consiguiente, se puede establecer que la agudeza es una característica del ingenio que cualifica al poeta y lo vuelve "hazedor", pero siempre acompañado de la claridad y de la excelencia. La primera, asimismo, dice mucho sobre la posición que tenía el asturiano con respecto a la perspǔcŭı̆tās y obscūrîtās. La claridad es fundamental para Carvallo, de aquí que las rimas de sus poetas posean elegancia, propiedad de raigambre retórica. La poética del jesuita, altamente retoricada, pretende establecer ciertas normas al furor divino del poeta, pese a que en su "Dedicatoria" ha insistido - e insiste a lo largo de la poética- que no pondrá límites a su creatividad. Sin embargo, es bastante cuidadoso y acompaña siempre al furor con el ingenio claro, agudo y excelente, o bien con la doctrina -el stŭdŭum. El ingenio-también el furor ${ }^{240}$ - y el ars dejan de ser polos opuestos totalmente gracias a la agudeza, misma que parece indicar un ingenio poético educado, aunque también -y en la mayoría de los casos- puede ser una cualidad natural de este o de la obra que tal ingenio crea.

\footnotetext{
${ }^{239}$ Il cannocchiale aristotelico, p. 1 (disponible en línea: https://archive.org/details/ilcannocchialear00tesa).

${ }^{240}$ Me gustaría señalar que en este punto el Cisne es similar a la poética de Pinciano: aunque existe una cercanía entre ambos términos, ingenio y furor, no pueden ser considerados capacidades intercambiables entre sí, como se analizará en el siguiente capítulo.
} 
Aún en este diálogo que define la invención y la materia poética, Carvallo sigue la doctrina del Examen de ingenios y determina que la agudeza también es una característica fundamental para saber si el individuo es fisiológicamente apto para la poesía:

Las señales que Huarte pone para conocer el hombre que està en el tercero grado de calor son, que se mostrara agudo en las obras de la imaginatiua sus costumbres seran, animo, soberuia, liberalidad, inclinado a mugeres, y el andar serà con muy buena gracia, y donayre. La habla serà abultada, y algo aspera, tendra pocas carnes, duras, asperas, y neruosas, las venas anchas. El color moreno, tostado, verdinegro, y cenizoso. E cabello y barba, y vello, gruesso, tiesso, aspero, y tostado. La cara no muy hermosa, todas las quales cosas son indicios de calor y sequedad, humor aparejado para la imaginatiua que han de tener los Poetas. (f. 17r)

La agudeza encabeza la lista de características físicas y conductuales que debe mostrar el poeta al estar "en el tercero grado de calor" y adjetiva a las obras de la imaginativa -aquellas que requieren proporción como la poesía y las matemáticas. No se puede decir que sea una característica física, ya que no se ve como el cabello, sino propia del ingenio, pues la imaginativa es una característica distintiva del ingenio.

La agudeza, pues, se encuentra presente en las obras de la imaginativa. Por ende, esta $-\mathrm{y}$ por extensión el ingenio- es aguda. De hecho, así se aclara cuando se habla de la excelencia poética: "Y quanto mejor y mas sutil ymaginatiua tuuiere, sera mas excelente Poeta. Porque inuentara mas sutiles y subidas cosas, mas raras y admirables" (f. 18r). La "mejor y mas sutil ymaginatiua" determina la calidad del poeta, porque se encarga de encontrar "sutiles y subidas cosas". Es decir, le permite penetrar mejor con su “filo" la realidad y encontrar la materia poética, misma que causará la admīrātĭo del público - efecto tan buscado en el Barroco.

La agudeza tiene también una función importante en las cuestiones métricas explicadas extensamente en el "Dialogo segundo de la disposicio[n] y forma de la poesia Castellana, que son versos, y coplas, con que se consigue el vno de sus dos fines, que es dar gusto”. Por el título del diálogo, quiero advertir cómo la agudeza se encuentra tanto en el dŏcēre-que se busca desde la

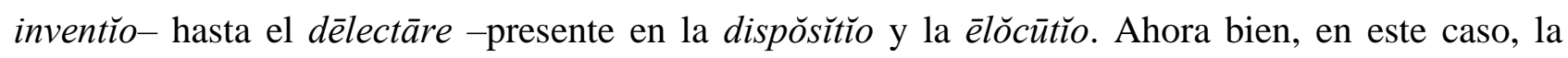
agudeza no deja de ser un adjetivo, pero califica ahora las dicciones "que tienen en la vltima el consonante, como perdi, perder, animal, amaras, y otros semejantes” (f. 64v). Igualmente ocurre con la sílaba acentuada al final, la cual, de encontrarse al final del verso, es "aquella vltima aguda [que] vale por si y por la penultima, y el verso que en aguda se acabare, tendrà vna syllaba menos de lo que suele tener, por valer aquella vltima por dos, y lo menos que se vsare destos agudos fines, serà mejor la compostura" (loc. cit. $)^{241}$. Estas se encuentran frecuentemente en los "Romance versos" y son poco

${ }^{241}$ La reglas de la "dicion aguda" y "consonante aguda" son repetidas más adelante en $\S . V$. "Las diferencias que ay de versos Castellanos", fols. 68v-69r (hay una errata en la foliación, por lo que en la editio princeps, en lugar de f. 68, aparece el 70), y en los fols. 71v-72r. 
recomendables para la épica, “do[n]de suenan muy mal” (loc. cit.). En suma, una cuestión de fonética y una licencia poética que aún hoy se conserva.

En este diálogo, empero, la agudeza no se restringe solo a la métrica. En §.IX., "De los villancicos", se dice que "de ser vna de las coplas que dichas quedan de dos, ó tres, ó quatro, versos, y ha de tener algun buen co[n]cepto, ó setencia, ò algun dicho agudo, ò donoso, como son las que pondre juntamente con los pies" (f. 82v). Carvallo anteriormente ha dejado ver sucintamente que el concepto se puede exponer a través de figuras -jeroglíficos $-{ }^{242} \mathrm{y}$ es, por tanto, una idea, la rēs, como en la Philosophia. Por lo tanto, cada copla del villancico debe contener en sus versos (entre dos y cuatro) una sola idea, o bien, sentencia o dicho agudo.

No se da mayor explicación sobre qué se considera como dicho agudo, sin embargo, se sabe que el villano o villancico

se llama ansi porque en la musica y vna tonada concertad con esta letra vieja.

$$
\begin{aligned}
& \text { Al villano si le dan, } \\
& \text { la cebolla con el pan. }
\end{aligned}
$$

Y por esta razon a la tonada la llaman el villano, y ni mas ni menos al bayle que co[n] ella se haze. (fols. $82 \mathrm{r}-82 \mathrm{v}$ )

Luego, la materia del villancico es agreste porque trata temas y tópicos relacionados con la villa o bien el campo -tal y como se ve en el dístico citado-, así como aquellos que retoman dichos populares -“Amor con amor se paga" (f. 85r). No obstante, se extiende a otros temas, porque en los ejemplos de villancicos subsiguientes se da cuenta también de temas religiosos, como, por ejemplo, el segundo villancico citado por Lectura: "Vie $[n]$ do Dios $q[$ ue $]$ el ho $[\mathrm{m}]$ bre humano, / por hambre fuera tomado, I oyse le dà en un bocado" (f. 83r). Entre estos dos tipos de materia, uno corresponde al concepto y a la sentencia -dicho grave ${ }^{244}$ - y otro al dicho agudo.

Me parece más probable que el dicho agudo y algunos conceptos estén reservados para los temas profanos y populares, mientras que las sentencias -y otro tipo de conceptos $^{245}$ - apuntan al

${ }^{242}$ La referencia está en la octava que finaliza $\S$. IX. "Prosigue la mesma materia, y tratase del principio que tuuieron las fictinoes" del "Dialogo primero": "El Hebreo de Dios siendo enseñado, / declar o sus conceptos con figuras, I antes de auerse letras inuentado, I pues estas Hierogliphicas pinturas / los Caldeos y Egypcios, han tomado, I a estos los Poetas imitando, / van en letras, figuras, trasladando" (f. 34r).

${ }^{243}$ Alberto Porqueras Mayo señala que esta canción es efectivamente bastante vieja y que tuvo gran popularidad durante los siglos XVI y XVII (vid. L. Alfonso de Carvallo, Cisne de Apolo, A. Porqueras Mayo ed., p. 199, n. 72).

244 "Vale assimismo dicho grave, y sucinto, que encierra doctrina, ò moralidad, digna de notarse" (Diccionario de la lengua castellana..., s. v. sentencia). El mismo Carvallo especifica más adelante que es "vn breue dicho, que muestra lo que ay o, que se deue seguir y sea licito" (f. 182v). Es, en pocas palabras, un dicho breve de carácter moral.

${ }^{245}$ Sin una mayor definición de concepto, más que la ya mencionada, no me parece pertinente delimitar que este pertenezca a una materia popular o sagrada, puesto que no es más que una "idea", sin mayor connotación. Además, más adelante, cuando Carvallo se preocupa por el "verso eroyco" enfatiza la importancia de que cada estancia englobe "en $s i$ la sentencia y concepto" (f. 88r). Podría decirse que ocurre lo mismo con la sentencia, pero si se entiende que esta es un "dicho grave", entonces se sabe que puede ser apta tanto para la materia del villancico -siempre que sea su fin el adoctrinar- como la épica, mientras que el concepto parece más general. Esto se correspondería en parte con las 
adoctrinamiento, como señala su propia tradición. Tal consideración, me parece, permite aceptar que el dicho agudo está más cercano a lo popular. De aquí a las connotaciones cómicas que pueda tener hay poca distancia. Sin embargo, en la poética dialógica no se desarrolla este aspecto como sí lo hace sucintamente la Philosophia.

Ahora bien, hay que notar un par de características más de los dichos agudos, mismas que comparte con los conceptos y las sentencias: la primera es la brĕvĭtās y la segunda algo que se podría definir como la necesidad o posibilidad de ser explicados. La brěvĭtās se entiende en el número de versos prescritos - un máximo de cuatro versos para su exposición. Esto configura la cabeza o letra del villancico que va acompañada por los pies, los cuales son "vnas coplas que se siguen tras de las letras, que son como comento dellas porque siruen de explanacion, ò de dilacion, o interpretacion de la cabeça" (f. 82v). Si los pies explican la cabeza que contiene el concepto o sentencia o dicho agudo es porque el sentido de estos va más allá de lo que en dos o cuatro versos puede decirse.

Su brěvĭtās se aproxima entonces a un aspecto que ya señalé en el caso de la Philosophia y que Rodríguez Beltrán apunta acertadamente. El crítico afirma que "se accede a lo hondo del sentido mediante los recubrimientos formales y estilísticos, pero estos no conducen a lo profundo de manera directa y llana, como si fueran el reflejo exacto de lo expresado"246. En consecuencia, la brěvĭtâs de la cabeza no expone literalmente su contenido y por esto el pie explica la cabeza, mientras que las figuras retóricas no son para ocultar el significado, sino para aclarar el concepto "porque mas se entienda con figura" (f. 38r). La brěvitās y las estrategias que se usan para clarificarla son una suerte

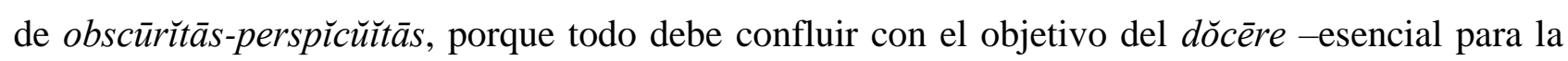
poética de Carvallo. Así, incluso la brěvĭtās, que implica de entrada cierta obscūrittās, persigue un objetivo didáctico $^{247}$.

observaciones hechas por Joaquín Rodríguez Beltrán sobre la sentencia, el dicho y el concepto de Gracián: "Sabemos, por la obra de Peregrini, que concetto ya se usaba en el italiano de mediados del XVII para referirse a un 'dicho' (detto), y algo análogo pareció ocurrir en el caso del español concepto: sabemos que, al menos después, se llegó a traducir la voz -ya ambivalente en latín- sententia, que tiene tanto el sentido abstracto de pensamiento como el concreto de dicho o sentencia. Pero, a pesar de la cercanía entre el concepto graciano y la sententia de la tradición latina, lo cierto es que la noción del jesuita aragonés es mucho más abarcadora" (op. cit., p. 42). Así que es posible que este sea el motivo por el que se agrega el adjetivo agudo al dicho, puesto que sentencia significa precisamente dicho grave; mientras que concepto sería un término general. De hecho, en el "Dialogo tercero", se dice que los dichos satíricos no deben oscurecer el concepto (vid. $144 \mathrm{v}$ ), por lo que este último sería la idea y el dicho una frase que lo recubre y que, a su vez, puede ser oscurecido o aclarado con otras figuras.

246 Op. cit., p. 14.

${ }^{247}$ Tanto el didactismo como la memoria aumentan con la brěvĭtās del verso - de ahí que al final de cada capítulo, Carvallo personaje sintetice el concepto en una octava, porque "el modo de deprender es mas facil, y en mas breue tie[m]po haze estando los preceptos en verso que en prosa, y despues se oluida mas tarde, que el verso es mas apto para la memoria" (f. 132v). El Cisne prefiere el verso a la prosa, no porque se acerque más a la divinidad o a la realidad, sino porque es más útil para el aprendizaje y la memoria, es mnemotécnico. 
Con base en lo anterior, me parece pertinente señalar que el Cisne ofrece un arte poética en donde se enfatiza en todo momento el equilibrio del binomio arte-ingenio ${ }^{248}$. La presencia del primer elemento es fundamental, puesto que evita cualquier exceso que pueda oscurecer la obra poética. La agudeza, empero, no es una cualidad relacionada como tal con el arte; en otras palabras, este o el stŭd̆̌um no "afilan" el ingenio para volverlo sutil ${ }^{249}$. A partir del binomio arte-ingenio y de su indudable importancia en la poética dialógica, me parece imperante recalcar este aspecto, porque la agudeza está presente en el binomio, pero pertenece intrínsecamente a su segundo elemento: el ingenio, aún y cuando una de las primeras menciones permite relacionar el arte con el ingenio. Sin embargo, es un caso aislado y la constante es que indica una característica de la capacidad creador.

Aunado a lo anterior, opino que la agudeza ayuda a inmortalizar las hazañas de los héroes. Mi interpretación está estrechamente relacionada con el efecto que tiene la brěvĭtās en la memoriauna enseñanza breve es fácilmente recordada-, pero no únicamente. En el "Dialogo Tercero, de la disposicion y forma de la Poesia, con que se alcança el segundo fin, que es aprouechar" -apartado $\S$ VIII, "De la historia y su prouecho"-, Lectura afirma que los romanos creían "que mayor premio se deuia a los Poetas que con la agudeza de sus ingenios celebraua[n] los hechos de sus capitanes, que a los mesmos que co[n] el trabajo de sus personas los executauan" (fols. 135v-136r). En breve, se coloca al poeta sobre el militar, gracias a la agudeza de ingenio, con la cual los poetas consiguen fijar los hechos en la memoria y otorgan la fama-tan importante en el mundo clásico y en el Renacimiento.

La agudeza aquí es un sustantivo que evidentemente connota una característica del ingenio: su sutileza o delicadeza. No obstante, no se dice con exactitud cómo es que la agudeza del ingenio actúa para conseguir, en este caso, la fama. Como ocurre con Pinciano, puedo suponer que está presente al momento de "penetrar" la realidad para encontrar la causa material del poema, o bien, en la sutileza presente en la obra. Me inclino, empero, por esta última, porque la mención se encuentra dentro de un diálogo que trata de la dispǒsĭtĭo del poema y de una de sus causas finales: el dŏcēre ${ }^{250}$.

248 Como anoté, esta dicotomía tiene sin duda como base el arte mayor horaciana ars-ingenium, pero no solo, sino que, siguiendo a García Berrio, forma parte de una tradición que se remonta a las retóricas del siglo XIV y a poéticas (en forma de paratextos o más formales) como las del Marqués de Santilla y Juan del Encina, cuya fuente primordial son las Instituciones de Quintiliano (vid. Formación de la teoría literaria moderna, 2, pp. 22-26). De hecho, Carvallo, como ya mencioné, ofrece una poética retoricada y dentro de sus fuentes también tiene un papel importante la obra del latino, lo que no le impide destacar la divinidad del lenguaje poético, como observa Fernández-Corugedo: "Lo que queda claro, pues, es que para Carvallo el lenguaje poético y el sagrado comparten el mismo carácter y que los conceptos poéticos y sagrados vienen a ser lo mismo" (op. cit., p. 278). El arte y el ingenio están balanceados y se destacan las cualidades de cada uno.

${ }^{249}$ Este hecho es aún más elocuente cuando revise la poética de Carrillo y Sotomayor, en donde la agudeza sí afila el entendimiento, la capacidad humana que él privilegia.

${ }^{250}$ Conviene resaltar que, al igual que en la Philosophia, el Cisne contempla como causa final de la poesía el dŏcēre y el dēlectāre, aunque Carvallo los concibe al mismo tiempo y no dependiendo de la causa que se priorice como Pinciano. Es decir, el poema da gusto -"Dialogo segundo"- y es de provecho - "Dialogo Tercero". Esto se explica porque Carvallo no sigue tan de cerca la teoría aristotélica y, por ello, no considera que la poesía solo deba tener una única finalidad. 
En conclusión, la agudeza está en cómo el ingenio del poeta expone la materia poética. Esto es en la verba y su disposición, que privilegia tal vez esa brěvĭtās didáctica que mencioné. Por supuesto, lo último es una suposición que colijo de lo expuesto a propósito de la obscūrítāsperspǔcŭı̆tās, pero no me parece conveniente asegurarlo ante la falta de detalles que ofrece Carvallo. No es pues evidente como sí lo es la tradición retórica de Carvallo, la cual no es únicamente de carácter clásico. El sintagma agudeza de ingenio ya estaba presente en la tradición retórica del siglo XV en España, como demuestra la disertación doctoral de Rodríguez Beltrán. Así que cabe la posibilidad de que el profesor jesuita haya sido inspirado por tal tradición, directa o indirectamente por alguna de sus auctoritates ${ }^{251}$.

La agudeza, como adjetivo de ingenio, se repite en "Dialogo Tercero": §.XX., "De las epigramas y padrones y diuisas". Cuando Lectura explica qué son los epigramas -el género agudo por excelencia en la tradición occidental- afirma que estos "no dizen todo lo que quieren dezir sino parte dello" (f. 154v). Por esto, se ayudan del "mote o figura que se pinta" (loc. cit.), sin por ello dejar de mostrar "la agudeza de sus ingenios" (f. 155v) solo a través del epigrama. La brěvĭtās del género -como el villancico- requiere de una explicación que en este caso da el "mote" - inscriptǐo'- o la "figura" - ‘imagen'. Sin embargo, estos no son indispensables para notar la habilidad del poeta que la creó: su dispŏsĭtĭo evidencia su agudeza de ingenio. Además, esta se observa nuevamente en un género caracterizado por la brěvǐtās, que provoca una obscūrĭtās no perniciosa a la obra poética. Estos aspectos determinan que Carvallo no aplique el sintagma agudeza de ingenio a todas las composiciones poéticas. Hecho que me parece sintomático, ya que demuestra que en el Cisne hay géneros poéticos agudos, como el epigrama.

Por otra parte, me parece bastante interesante que el epigrama descrito por Carvallo se aproxima más a la subscriptı̌o que acompaña a la pictūra del emblema que al epigrama de Marcial usado por Pinciano para ejemplificar el género. La razón obedece posiblemente a que una de sus fuentes modernas son los Emblemas morales de Sebastián de Covarrubias. Por esto, considero que el padre jesuita pensaba en tal obra al tratar sobre el epigrama, aunque no se da ningún ejemplo de este. Sin embargo, no quiero desestimar las implicaciones que esto tendría de ser así, porque la agudeza tocaría entonces temas morales y doctrinales, y no solo los populares, profanos e incluso cómicos de los dichos agudos. A propósito, quiero hacer hincapié en que el epigrama se describe en el "Dialogo Tercero" que se preocupa por el dŏcēre, lo que ayuda a justificar esta interpretación. Así, me parece que las dos lecturas de la agudeza -moral o popular- obedecen a lo que está connotando: en una es

${ }^{251}$ Considero fundamental reiterar la deuda que la crítica tiene con este corpŭs, puesto que aún se deben comprender mejor las estrategias literarias que sus autores usaron, lo cual va más allá de identificar las citas directas e indirectas - primer paso esencial. De esta forma, no solo será más claro el desarrollo de conceptos tan importantes como la agudeza, sino que también se comprenderá cómo se recibía, producía y transmitía el saber tanto entre los humanistas como los poetas. 
una característica del ingenio y en otra es un tipo de dicho. Esto volvería al ingenio también moral y doctrinal, algo que recuperaré más adelante. Por el momento quiero observar la flexibilidad temática puede implicar el término analizado, aún y cuando la cualidad primordial con la que se le acompaña no cambia: la brěvittās.

El "Dialogo quarto, de el decoro que se dene [sic] guardar en la poesia de la vena, y furor poético" enriquece la agudeza carvallesca. Esta no solo es necesaria para la producción poética, sino también para la recepción de la misma, e incluso para el conocimiento en general. De tal guisa, en el apartado §. VI., "De las figuras que en las maneras de dezir se cometen", Lectura comenta que el símil ayuda a "los que no son muy agudos" porque "mejor entiende lo que perciuen por algun sentido corporal, que lo que pertenece al entendimiento, y los similes pertenecen a la vista, y ansi se entie[n]de mejor la doctrina mediante ellos, que mediante los argumentos que pertenecen al entendimiento" (f. $181 v)$.

A la luz de tales afirmaciones no es claro si la agudeza es una capacidad "afilada" o únicamente una cualidad propia de la capacidad receptora humana, pero es claro que de una u otra forma es de carácter natural. La agudeza, en este sentido, no se adquiere, al igual que el ingenio. Además, su presencia es esencial para comprender argumentos propios del entendimiento -con posible referencia a las pruebas lógicas. Por esto, la poca agudeza provoca que el individuo se valga de los sentidos sensoriales, como la vista y, a nivel de discurso, estos se observan en las figurae elocutionis como, por ejemplo, el símil, que se basa en imágenes semejantes y por ello recae en la vista.

Ahora bien, comenté que no se puede saber si la agudeza es una capacidad en sí o una característica, y para develar esto he considerado, además de lo hasta aquí expuesto, lo siguiente. En este fragmento, Carvallo, como Pinciano, considera a los individuos que naturalmente se encuentran en desventaja. No obstante, el vallisoletano habla de aquellos que pretenden crear y son poco ingeniosos, mientras que el jesuita se refiere a aquellos receptores que son poco agudos. La comparación me parece pertinente en tanto se visualiza la capacidad creativa del ingenio y la receptora de la agudeza. Sin embargo, esta división no debe entenderse como dos capacidades diferentes. Recuérdese que el ingenio en la Philosophia también puede ser receptor (vid. "Capítulo III") y, en el Cisne, la agudeza puede connotar una característica del ingenio. De hecho, me parece que aquí Carvallo recurre a una elipsis y toma solo el adjetivo agudo para referirse a un ingenio agudo. En consecuencia, opino que la agudeza connota lo "afilado" del ingenio; es decir, es una característica nata que le permite a la capacidad humana penetrar mejor en la realidad. Tal y como observé en la Philosophia. 
En los últimos folios de la poética, que tratan de los diferentes tipos de furor-amoroso, profético y poético-, Alfonso de Carvallo adjetiva nuevamente al ingenio como agudo y delicado (vid. f. 203r) o solo sutil (vid. 205r). Todas estas menciones aluden a una cualidad propia de un tipo de ingenio y reafirman las relaciones entre ingenio, agudeza, sutileza y delicadeza que expuse más arriba. Así, en §. XI., "Las differencias que ay de furor, y la razo[n], porq[ue] los Poetas da[n] en enamorados, y como luego dan en ser recogidos", Lectura conciencia sobre el peligro que el poeta enfrenta ante los "vanos amores" (f. 203r), pues no son doctrinales o morales. Sin embargo, la voz alegórica de la poética no está preocupada al respeto. Ella sabe que los poetas son "personas de agudo ingenio, [que] lo vienen a conocer y destinguir, lo que en aquellos vanos amores ay de bueno, y lo que ay de malo, dexando lo malo y mejorando lo bueno que es el amor y la belleza" (f. 203v).

El agudo ingenio discierne entre lo bueno y lo malo, lo que recupera el carácter moral que este puede poseer. Además, con su capacidad creadora sabe aprovechar lo primero y mejorarlo. En suma, la agudeza efectivamente es una cualidad del ingenio, que le permite observar y comprender mejor la realidad. Incluso, habilita a la capacidad creadora humana para tomar decisiones de carácter moral y doctrinal, aunque no deja de ser defectible. Lectura, más adelante, lamenta que los agudos ingenios de Ovidio y Juvenal hayan producido obras “sin fructo y prouecho" (f. $211 \mathrm{v})^{252}$. Por ello, no es suficiente la agudeza de ingenio para crear obras de provecho a la República, sino que el poeta, se puede suponer, debe tener una optima educación moral, específicamente cristiana.

Ahora bien, pese a los errores que puedan cometer algunos agudos ingenios, es innegable que la agudeza también es moralizada por Alonso de Carvallo y se integra-como la brěvittās-al proyecto educativo de su poética. Esto porque los preceptos del Cisne, su arte, son de tipo técnico, moral y doctrinal, lo que motiva no solo el uso de fuentes clásicas, sino también las numerosas citas de pasajes bíblicos y la cristianización en su momento de la materia pagana, útil para el poeta, pero inmoral en principio. El Cisne es entonces una poética cristiana que ennoblece al poeta con características como la agudeza, aquella capacidad del ingenio que le permite entender la realidad y discernir entre el bien y el mal de cierta materia poética.

Para finalizar, me gustaría recuperar las principales connotaciones que la agudeza tiene en el Cisne. Primero, es sinónimo de sutileza y delicadeza y puede calificar tanto la capacidad humana del ingenio como las obras que se producen con este. Además, como en la Philosophia, está estrechamente relacionada con la brěvittās. Por tanto, se presenta como característica de géneros poéticos breves de carácter popular -los villancicos-o bien doctrinal -los epigramas-, los cuales

${ }^{252}$ Carvallo solo ofrece el nombre de una de estas obras: El arte de amar (vid. f. 211r). El jesuita resalta los prejuicios que los "vanos amoles" pueden traer a los poetas. Por supuesto, para esto, obvia o desconoce los motivos políticos que provocaron el exilio del poeta latino, ya que su interés está en la cuestión moral. 
siempre necesitan de una explicación porque no muestran literalmente su enseñanza. En consecuencia, se debe "penetrar" en ellos con ayuda de figuras retóricas o imágenes.

Entre estas, la principal connotación de agudeza es indudablemente como característica del ingenio, a quien le permite penetrar mejor en las situaciones y comprender cabalmente la realidad, con lo que se resalta su capacidad receptiva. Es más, gracias al carácter moral de la poética, la agudeza puede fungir en algún momento a guisa de juicio y permite entonces distinguir al poeta entre lo bueno y lo malo de un tema poético, como el amor. Todo esto porque Alfonso de Carvallo recupera la principal denotación del término analizado: la agudeza es "afilada" o "puntiaguda" y la "metáfora de la punta" se explota en diversos grados y matices, dependiendo de cada connotación que se le dé.

\section{Francisco Cascales: Tablas poeticas (1617)}

La última poética dialógica del corpŭs que analizo son las Tablas poeticas. En esta obra, el diálogo se desarrolla entre Castalio - personaje portador de la voz de Cascales-y Pierio -interlocutor curioso que representa la voz del neófito. El objetivo principal de su argūmentātĭo es glosar el Arte poética de Horacio. Para esto, el humanista Cascales - de manera similar a Pinciano y Carvallo- se basa en auctoritates clásicas, a las cuales se acerca principalmente de forma indirecta a través de comentaristas italianos -como Minturno y Robortello-, a los que traduce en numerosas ocasiones. El resultado es una poética ecléctica, aunque el saber no se encuentra tan asimilado como en las dos poéticas analizadas. Tal hecho se aprecia en las connotaciones de las veinticinco ocasiones que aparece la palabra agudeza dispersas en la poética. De estas, veinticuatro menciones cumplen con una función adjetival -aspecto que ya he notado en la Philosophia y el Cisne.

En la primera parte de las Tablas dedicadas a la "Poesia in genere" se encuentra la "Tabla primera de la definición Poetica, de su materia, forma, y fin, de la diuision de las Poesias, de la diferencia, y co[n]cordancia dellas". Castalio enuncia aquí las bases de la poética, entre las que se encuentra la tópica mayor horaciana, en particular el binomio más querido de la crítica renacentista para la defensa y justificación del quehacer poético: el dŏcēre-dēlectāre ${ }^{253}$. Sin embargo, como advertí, su tratamiento no es propiamente horaciano, sino ecléctico ${ }^{254}$. Tal principio, enseñar con deleite, debe regir la finalidad de la poesía ${ }^{255}$. Pierio está de acuerdo con la explicación, pero no deja de preguntar: ¿"quando nos representan cosas tristes, y dolorosas, y quando nos representan casos

\footnotetext{
${ }^{253}$ El excursus de dicha dualidad tanto en la tradición italiana, como en la española, ha sido largamente estudiado por Antonio García Berrio en los dos volúmenes que conforman la Formación de la teoría literaria moderna: 1) La tópica horaciana en Europa (vid. pp. 331-375) y 2) Teoría poética del Siglo de Oro (vid.pp. 423-481 passim).

${ }^{254}$ Para las fuentes e influencias de este pasaje en específico, así como un desarrollo del tópico en la tradición italiana y española vid. A. García Berrrio, Introducción a la poética clasicista. (Comentario a las Tablas Poéticas de Cascales), pp. 96-106.

255 "El fin de la Poesia es agradar, y aprouechar imitando [...]. De manera que el Poema no basta ser agradable, sino prouechoso, y moral: como quien es imitacion de la vida, espejo de las costumbres, imagen de la verdad" (pag. 32).
} 
atroces, y crueles, esto como puede deleytar?" (pag. 34) $)^{256}$. A lo que su interlocutor afirma: “Agudo soys" (loc. cit.).

La primera mención es un adjetivo que se refiere a la capacidad de Pierio de ver más allá, como el águila. Este animal está presente en frases como "Vé mas que un águila", la cual es glosada por el Diccionario de Autoridades como: "Phrase vulgar que se dice por aquel que tiene la vista perpicáz, agúda, y penetrante, à imitación del Aguila" ${ }^{257}$. Castalio no hace una comparación directa con el animal; sin embargo, se alude a quien es lo suficientemente agudo como para penetrar en los razonamientos del otro.. La idea de la agudeza como capacidad de "ver más allá" está presente en la tradición anterior a Cascales y ya la he observado también en la Philosophia y en el Cisne. No obstante, en Pinciano he supuesto y en Carvallo he afirmado que el adjetivo califica al ingenio y su capacidad receptora. Por el contrario, me parece que Cascales, sin especificarlo, cualifica al entendimiento de Pierio, el cual es "puntiagudo". La razón de esto es por el papel poco privilegiado que tiene el ingenio en las Tablas (vid. "Capítulo III").

En la "Tabla qvarta. De la Sentencia" ${ }^{258}$, Castalio aclara que la sentencia "significa dos cosas: la vna, el concepto del animo ${ }^{259}$ : la otra, lo que comunmente dezimos Sentencia, o dicho moral, y agudo" (pag. 129). En otras palabras, el primero es una idea y, el segundo, una frase breve hecha que enmarcan un saber común y compartido. Como en otros momentos del análisis, la agudeza adjetiva un elemento poético breve. Por otra parte, se puede establecer que la agudeza de Cascales implica una brevedad únicamente de forma, porque lo agudo no es el "concepto del animo" -que compete a la poesía lírica-, sino la "Sentencia" o "dicho".

La "Sentencia, o dicho moral, y agudo", conforme a Aristóteles, es “de cosas vniversales, no limitadas del tiempo, lugar, y personas, ni ta[m]poco de todas las cosas generales, sino de aquellas en quien co[n]sisten las actiones humanas, las quales pertenecen a las costumbres, $\mathrm{y}$ a la comun opinion de los hombres, y a los casos q[ue] mas ordinario suceden” (pag. 130). En su comentario, García Berrio señala que la definición que ofrece Cascales no corresponde a la Sióvoı $\alpha$ (pensamiento) de la tragedia descrita por Aristóteles. Más bien, “se aproxima al retórico-filosófico $\gamma \nu \omega ́ \mu \eta, v e r d a d$

\footnotetext{
${ }^{256}$ Recuérdese que en la "Advertencia” comenté que la poética de Cascales, a diferencia del resto, señala que son páginas y no folios.

${ }^{257}$ Diccionario de la lengua castellana..., s. v. águila, segunda acepción.

${ }^{258}$ Mencioné lo disperso y poco frecuente del término agudeza. Por esto, no hay mención alguna de esta en la "Tabla segunda. De la Fabula" ni en la "Tabla tercera. De las Costumbres", lo que dice mucho sobre las connotaciones que agudeza tiene en las Tablas.

${ }^{259}$ La distinción es la misma que recupera Joaquín Rodríguez Beltrán y que más adelante se transfiere al término de concetto en la tradición italiana (vid. supra). Me parece importante señalar, empero, que Cascales hace hincapié en que es un "concepto de animo". Alude entonces al fenómeno que Rodríguez Beltrán identifica con la poética italiana de Matteo Peregrini publicada en 1639, mientras que las Tablas, como se sabe, terminaron de componerse en 1604. Debido al complejo juego intertextual de la poética del murciano no es posible saber si esta definición la tomo de alguna poética italiana o no. Aún con esto, es notable que el concetto del italiano ya está presente en el "concepto de animo" del español.
} 
general, proverbio universal, o más apropiadamente 'sentencia' en su traducción latina"260. En otras palabras, una sentencia de raigambre retórico y que acerca el término al ámbito del èthŏs, pues pertenece a las "costumbres".

Por supuesto, lo anterior es resultado del eclecticismo de las fuentes que utiliza Cascales para la conformación de su poética ${ }^{261}$. Aspecto que, más que desafortunado ${ }^{262}$, ofrece un acercamiento distinto a sentencia, pues recupera y continúa una tradición. De hecho, el término usado por el humanista ofrece precisamente la posibilidad de que tal sentencia-vista como $\gamma \nu \omega ́ \mu \eta-$ pueda ser o

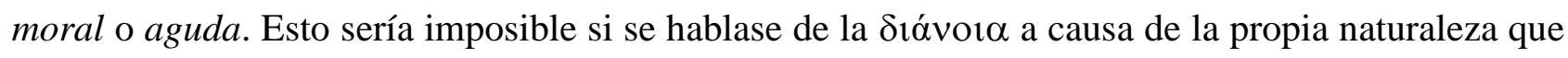
Aristóteles le da en la Poética.

Ahora bien, a lo largo de esta "Tabla", Castalio ofrece diferentes clasificaciones para la sentencia. La primera de ellas obedece a su simplicidad o si son manifiestas y claras. Me parece importante comentar el segundo tipo ahora porque, aunque no se mencione directamente a la agudeza, su cualidad de manifiesto y claro exige una explicación de ser necesaria. Afirma Castalio: "sobre las cosas inciertas, y dudosas, y fuera de la opinion vulgar se an de hazer las Sentencias acompañadas de su causa. Y esto de dos maneras, anteponiendo, o posponie[n]do la razon” (pag. 132).

Las Tablas, como habría de esperarse, se inclinan hacia la persp̌čŭtās en la poesía y para favorecerla pide que se aclare con "razon" toda sentencia que pudiese ser oscura. De tal forma, cuando Castalio afirma que la sentencia que se desarrolla en esta "Tabla" corresponde al "dicho moral, y agudo", quiere decir que un tipo de dicho agudo, por su brĕvitās -u otras razones-, puede resultar oscuro: requiere luego una explicación por parte del poeta. Considero que "decir mucho en pocas palabras" puede ser una cualidad que, junto con Pinciano y Carvallo, Cascales recupera para la agudeza. Sin embargo, no se puede dejar de señalar que tal solicitud no está hecha en sí a la agudeza, sino a un tipo de sentencia.

Castalio continúa y ofrece a su interlocutor dos clasificaciones más para las sentencias, las cuales provienen también de la poética de Minturno. Una de ellas depende del objeto que enuncia y su finalidad, y comprende a las sentencias reales, personales, intelectuales y morales. La segunda clasificación se divide en agudas, sonoras y graves, en correspondencia con los fines de la poesía, porque "es el officio d[e]1 Poeta enseñar, deleytar, y mouer, justo es, que aya otras tantas maneras de Sentecias" (pag. 135). La clasificación la realiza el humanista de acuerdo con su finalidad y aunque

${ }^{260}$ A. García Berrrio, Introducción a la poética clasicista, pp. 212. Esta definición de sentencia es una de las pocas novedades que el comentarista de Cascales acepta en las Tablas, ya que su distinción entre concepto y sentencia es fundamental para el desarrollo del así llamado conceptismo (id. pp. 212-214).

${ }^{261}$ Para la formulación de tal definición, además de la presencia del Aristóteles retórico y de la poética de Minturno, Benito Brancaforte ha identificado también el trabajo del italiano Giraldi Cintio, De’ Romanzi, delle Comedie e delle Tragedie, Ragionamenti (vid. Francisco Cascales, Tablas poéticas, B. Brancaforte ed., p. 86, nota a la línea 14)

${ }^{262}$ Vid. A. García Berrrio, Introducción a la poética clasicista, p. 214. 
no se vuelve explícita su relación, se puede concluir que las sentencias graves enseñan, las sentencias sonoras deleitan y las sentencias agudas mueven.

Dentro de las poéticas que analizo, es la primera vez que lo agudo se asocia a la capacidad del mŏvēre y, aunque Castalio no profundiza en la definición de cada una de estas sentencias, opino que tal capacidad se debe a lo "puntiagudo". En otras palabras, si se da una interpretación metafórica al pasaje, entonces la sentencia aguda puede mover el ánimo humano porque, como una "punta", penetra en sus emociones. Las preguntas que parten de esto son principalmente dos: ¿qué considera Cascales como la "punta" y cómo se consigue? Además, ¿este tipo de sentencia tiene alguna característica particular que la haga ser precisamente "puntiaguda", es decir aguda?

Para responder tales incógnitas, lo único que se ofrece al lector es un ejemplo: "Aguda sera, como: La vida aprueba el fin, al dia la noche" (loc. cit.), una traducción del verso 31 de la canción "Nel dolce tempo de la prima etade" del Canzoniere de Petrarca. A partir de este verso aislado, que sirve a Cascales precisamente como sentencia, se nota dos tipos de metáfora: una entre opuestos vida/fin, entendido como muerte; día/noche- y la otra por analogía-vida/día. Ambas comparaciones se unen con el verbo "aprobar" para indicar precisamente que solo en la muerte o en la noche se puede valorar la vida o el día. Esta construcción movería el ánimo de los receptores al cuestionarse sobre la vida misma gracias al juego de oposiciones y semejanzas.

En comparación con el verso de Petrarca, los ejemplos de los otros dos tipos de sentencia son más sencillos, ya que solo tiene un término opuesto entre sí -como el grave, "La vida humana es humo q[ue] no buelue"- o no tienen metáfora alguna-como la sentencia sonora, "Dichosos ojos, que la vieron viva". Se nota entonces dos peculiaridades en la sentencia aguda, la primera es el número de metáforas y, la segunda, la relación entre los términos que la conforman. La sentencia aguda es prácticamente un juego conceptual circunscrito a una sola frase que, además, podría ser adornada con más figuras.

Con base en lo anterior, Castalio instruye a Pierio: "Estas Sentencias, que dichas ansi senzillamente son buenas, dichas con varias figuras, o co[n] interrogacion, o excalmacion te[n]dra[n] mas energia, y vigor" (pags. 135-136). En "efecto las Sente[n]cias son mas eficaces y vigorosas quando lleuan en si algunas de las figuras y colores Retoricos; como de cualquier mediano juicio se dexa considerar" (pag. 137). Es claro que el preceptor murciano considera las sentencias como frases ya hechas y, en consecuencia, las metáforas que integran la sentencia aguda las ve como propias de este tipo -intrínsecas. Por esto, se le puedan agregar más "colores Retoricos" sin caer en el vicio de la obscūrĭtās.

La voz autorizada de las Tablas enuncia posteriormente particularidades y reglas sobre la sentencia, entre las que cabe resaltar las que se hacen con base en el decoro-innegable hilo conductor 
de la poética. Este determina que los portavoces de las sentencias son exclusivamente los hombres viejos $^{263}$, porque ellos, a partir de la experiencia que han acumulado, poseen un saber empírico que se confirma con estas frases de saber universal. Desafortunadamente, más allá de esta precisión, no se hace una tipología de tales portadores del saber, que podría ofrecer información sobre alguna cualidad particular y necesaria para decir las sentencias agudas y no solo la "experiencia" que señala una característica general. Sin embargo, sí se menciona que las sentencias son restrictivas del género masculino, porque son "traidas de lo mas secreto de la Philosophia" (pag. 138).

Se desconoce si la cuestión de género se debe a una tradición misógina, que contempla como argumento una determinada concepción fisiológica. No obstante, es más probable que solo siguiera cierta tendencia de pensamiento sin dicha justificación. Mi consideración se basa en la ausencia de explicaciones fisiológicas para la creación poética a diferencia de lo que encontré en Pinciano o Carvallo. De esta forma, tal restricción no aporta mucho a las características propias y esenciales del portador de la sentencia. Asimismo, ni lo que se define como el fin general de las sentencias - "haze[n] el Poema morato" (loc. cit.)-, ni el resto de las recomendaciones que se hacen a propósito de esta ayudan de alguna forma a dar más luz sobre el concepto que me atañe, aunque más adelante se anota el uso decoroso de la sentencia en algunos géneros poéticos ${ }^{264}$.

Se deja un momento la cuestión de la sentencia y, en la “Tabla Qvinta. De la Diction”, Castalio divide la dicción “en Letras, Sylabas, Palabras, Numero, Verso y Phrasis” (pag. 144). De estas seis partes, la agudeza califica a una de las "Letras" y durante el "Verso" tiene un papel fundamental por el "acento"265. De tal guisa, dentro de "las virtudes de las letras"266, hay una que es aguda: "La i, aguda y humilde" (pag. 151), refiriéndose a su sonido y es humilde porque fácilmente puede perderse entre otras vocales -pienso en los diptongos ${ }^{267}$. Esta reflexión propicia la subsecuente división que se

263 "Pincipalmente dira Sentencias vn hombre viejo, y aquel viejo que tenga vso, y experiencia de muchas cosas: porque no es cosa decente, antes monstruosa, introducir a vn niño diciendo Sente[n]cias" (pag. 137).

${ }^{264}$ Pese a la falta de especificidad que hay sobre la sentencia aguda, no deja de ser interesante señalar que es preferible usar las sentencias en la tragedia que en la comedia, debido al carácter moralizante que poseen (vid. pags. 141143). Sin embargo, como tampoco se ahonda en qué tipo de sentencias pertenecen a una u otra, no es posible afirma nada sin caer en la especulación. Asimismo, ocurre en la segunda parte de sus tablas que tratan de la "Poesia in specie", donde Pierio comenta en la "Tabla" dedicada a la comedia: "De la Sentencia, ya se que fuera de la Tragedia a quie[n] mas sirue es a la Comedia: porque como esta mira principalmente a las costumbres, y es vn espejo de la vida humana, vsa en muchas ocasiones sentencias endereçadas a este fin" (pag. 385). Con esto, la cuestión de las sentencias como transmisoras de comportamientos y con miras a la educación moral es más bien general, por lo que queda pensar únicamente en un tipo de comportamiento que es propiamente agudo, sin que se diga con exactitud cuál es.

265 Antes de que Castalio se detenga en las letras, menciona ya a la agudeza como adjetivo del acento para explicar las diferentes licencias poéticas del verso: "Dizen que este verso acaba en acento agudo; y es falso: porque no ay contraction en remate de verso" (pag. 150). De hecho, en las Tablas, como se verá, el acento agudo tiene un lugar importante en la dicción.

${ }^{266}$ La exposición de Cascales tiene sus antecedentes más antiguos en el Crátilo de Platón y que forma parte de las preceptivas fono-estilísticas, que habían dejado de tener tanta presencia en las poéticas de los Siglos de Oro, como comenta García Berrio (vid. Introducción a la poética clasicista, p. 230).

${ }^{267}$ Tal suposición se sostiene con el resto de las "virtudes de las letras", en donde se describe precisamente su sonoridad (vid. pags. 151-153). 
hace para los acentos, de suma importancia en la poética porque -señalan Emiliano Diez Echarri y Marx Arriaga ${ }^{268}$ - las Tablas se inclinan una vez más por la tradición clásica -aunque anacrónica- y exaltan la importancia del ritmo en los versos, el cual se logra con la correcta colocación del acento ${ }^{269}$.

Para esto, no obstante, procura actualizar las nociones de la métrica clásica, a la vez que mantiene su esencia:

En las sylaba se estudia la cantidad: porque vnas son breues, y otras largas. La breue co[n]sume vn tiempo, y la larga dos. Esta cantidad no pertenece al Poeta vulgar: porque en los versos de qualquier lengua vulgar no se mira la cantidad de las sylabas, como entre los Latinos, y Griegos. Pero consideranse los acentos graue y agudo, que con el circunflexo no se tiene cuenta; como en esta palabra, Románo, la sylaba de en medio goza de acento agudo, y la primera y vltima son graues. Y esta es maxima, que vna diction, por larga que sea, no puede tener mas vn acento agudo. (pag. 178)

Para Cascales, el acento agudo sustituye la sílaba larga en parte, porque solo es posible tener uno de estos en cada palabra. De tal guisa, se distancia de la métrica latina, con el fin de conjugar los elementos clásicos con la tradición prosódica hispana desde Nebrija.

De cualquier manera, con estas consideraciones, el acento no obedece únicamente a una cuestión fonética -que corresponde a "las virtudes de las palabras"-, sino también a una cuestión de cantidad silábica. Por lo tanto, sin dejar de asociarse a la cuestión fonética, tiene implicaciones más importantes en la métrica ${ }^{270}$. Se determina, por consiguiente, una clasificación del número de sílabas que puede tener una palabra ("diction" como le llama en ocasiones Cascales), en donde siempre es necesaria la presencia del acento agudo ${ }^{271}$, ya que este "haze numeroso el verso" (pag. 180) y determina así la correcta escansión de los versos ${ }^{272}$. En suma, su importancia es capital para el sistema métrico básico de Cascales, pero no ofrece ninguna característica esencial o particular de la agudeza.

${ }^{268}$ Vid. E. Diez Echarri, Teorías métricas del Siglo de Oro: apuntes para la historia del verso español, p. 134; M. Arriaga Navarro, ¿Qué era el verso en los siglos XVI Y XVII? En busca de una teoría del verso en las poéticas del Siglo de Oro, pp. 83-84.

${ }^{269}$ Se afirma en las Tablas que para hacer un verso números -rítmico- "se co[n]viene conocer los tiempos de las sylabas; y porque de las sylabas se haze la diction, y cada diction tiene su acento, tambie[n] es necessario tener noticia d[e] los acentos" (pag. 177).

270 "Sabido esto, aueis de saber, que la buena medida del verso consiste en poner en sus deuidos lugares el acento predominante" (pag. 179). Por supuesto, esta consideración parte únicamente de las breves explicaciones que ofrecen las Tablas, puesto que, como indica García Berrio en su comentario a este fragmento, las reflexiones sobre métrica y fonética en los Siglos de Oro fueron muy ricas y variadas (vid. Introducción a la poética clasicista, p. 248-252) y los exhaustivos trabajos de Diez Echarri y Arriaga Navarro lo demuestran.

271 "O la diction es monosylaba, o polisylaba. Si es de vna silaba, el acento que tiene es agudo, como sol, mal, bien, [et]c. Si es de dos sylabas, la primera es aguda, y la otra graue, como ca[n]to, cielo, ramo, [et]c. Si es de tres, y demas, o tiene la penultima breue, o larga. Si larga, en ella está el ace[n]to agudo, como Castelláno, Espáña, [et]c. Si la penultima es breue, el acento agudo predomina en la antepenultima, como cántaro, pacífico, melancólico, precipitándose, [et]c." (pags. 178-179). Como puede verse, se refuerzan los dos principios señalados: la identificación del acento agudo con la sílaba larga y que tal acento se presenta solo una vez en cada palabra.

272 Sobre esto se ahonda al hablar de los "versos Castellanos" (pag. 194): "Este verso puede ta[m]bien co[n]star de diez sylabas, por acabar los finales de cada medio verso en acento agudo" (pag. 197). Y más adelante: "Los versos Castellanos de arte menor constan de siete sylabas, si acaban en acento agudo: de ocho, si en graue: de nueue, si en esdrújulo" (pag. 198). Aquí, sin embargo, se debe hacer hincapié en que tal descripción de los acentos ya está más cercana a la tradición hispánica y hace una clara referencia al aspecto fonético de los versos. Se demuestra que la doctrina de 
Algo similar ocurre con la siguiente mención del término que me interesa. Durante la revisión que se hace a la "phrasis" -última parte de la diction que se trata en la "Tabla" y que traduce y simplifica la poética de Minturno ${ }^{273}$-, se dice que la "Phrasis Poetica es algo diferente de la oratoria, y de la familiar; que si bien a pocos terminos en prosa, que no se puedan vsar en verso, ay muchos en verso, que no se pueden vsar en prosa" (pags. 200-201). La "Phrasis en conclusión [h]a de tener estas siete virtudes, clara, graue, ornata, presta, morata, verdadera, grande" (pag. 203). Con "phrasis" se entiende entonces un conjunto de cualidades estilísticas que debe tener la oración poética. Dicho de otra forma, es el estilo poético ideal de Cascales, con evidente raigambre retórico ${ }^{274}$.

Ahora bien, entre las siete virtudes requeridas, la morata:

co[m]prehende, y descubre las costu[m]bres del hombre, guardando las circunstancias de las cosas, de los officios, del lugar, del tiempo y todo aquello que llamamos ley del decoro; y assi la Prasis vnas veces es magnifica, otras clara, otras confusa, y obscura, otras aspera y agra, otras benigna y dulce, otras sutil y aguda. (pag. 208)

En este fragmento, Carvallo asocia los términos agudeza y sutileza, creando una equivalencia semántica que no llega a la identificación del uno con el otro. Se entiende además que la existencia de la phrasis sutil y aguda se debe a múltiples factores. Incluso puede estar relacionada con uno o varios objetos u oficios en específico, aunque todos están supeditados a la "ley del decoro". No se dice más al respecto, pero queda claro que la agudeza puede también calificar las "costu[m]bres del hombre"; es decir, es un modus vivendi, lo que recuerda que existe un tipo de sentencia aguda que también se relaciona con el èthŏs.

En consonancia con lo anterior, durante las “Tablas de la Poesia in specie”, Cascales emplea nuevamente el término agudeza para adjetivar una cualidad de un tipo de sentencia que se asocia a las costumbres. El objetivo del murciano es siempre establecer la "ley del decoro" en los géneros poéticos. Así pues, se trata de la sentencia aguda en la "Tabla segvnda. De las Epicas menores. De la elegia". Como indica ya el título de la "Tabla", la elegía pertenece a las "épicas menores" y se define como "Imitacion de vna perfecta action lamentable" (pag. 302) 275, cuya elocución se basa en “sentencias breues, y agudas: su estilo deue ser llano, agadable y gallardo" (pag. 304) ${ }^{276}$. La agudeza

Cascales en cuanto al verso no estaba fijada, posiblemente por las fuentes traducidas, como sugiere García Berrio (vid. Introducción a la poética clasicista. p. 250), y también por sus intentos de actualizar ciertos elementos de métrica latina, como parte de su proyecto de imponer la poética clasicista a sus contemporáneos y evitar lo que él consideraba falta de decoro tanto en esta característica del fenómeno poético, como en el resto.

${ }^{273}$ Vid. id., p. 268 y B. Brancaforte, op. cit., p. 124, nota a la línea 12.

274 Antes de llegar a las siete cualidades propias de la frase poética, Cascales hace una revisión puntual de la "rueda virgiliana" del estilo (vid. pags. 201-203), con lo que se entiende que se basa, como sus contemporáneos, en la preceptiva retórica.

275 García Berrio comenta que la definición de Cascales coincide con la de Minturno, así como también con la de Pinciano y Herrera (vid. A. García Berrio, Introducción a la poética clasicista, p. 332-333).

${ }^{276}$ Es importante mencionar que este pasaje no es una traducción ad litteram de la poética de Minturno, el cual no dice que la sentencia deba ser breve y aguda, pues se lee textualmente: "Nè si dubita, le parti, che fanno la forma dell'elegia, essere la favola, i costumi, le sentenze, e le parole” (apud F. Cascales, op. cit., p. 177, nota a la línea 2). 
es un adjetivo que continúa asociándose a la brěvĭtās, porque está además presente en la descripción de un género que no es de largo aliento como la épica. Además, recuérdese que la sentencia también tiene esta una cualidad.

La segunda ocasión que se menciona a la agudeza en las "Epicas menores" es para exponer la sátira. Para esto, se vuelve sobre el aspecto morato relacionado con la agudeza o, más bien, con la sentencia aguda. Cascales recupera parte de lo dicho en la "phrasis", ya que la sátira que le interesa es la "nueva", aquella que es "imitacio[n] de vna viciosa, y vituperable action, con versos puros y desnudos, para enmendar la vida" (pag. 306). En este sentido, Castalio cataloga este tipo de épica menor como morata "porque en ella no se haze otra cosa que enmendar las costumbres, y por ta[n]to el Satirico deue saber mucho d[e] la Filosofía moral: ama vn dezier proprio y puro, y en las sentencias la agudeza" (pags. 311-312). Esta es la única ocasión en que la agudeza no es un adjetivo, al menos gramaticalmente hablando ${ }^{277}$, ya que su función sigue siendo el de calificar a un sustantivo, las sentencias.

No hay mayor reflexión o exposición a propósito, puesto que se están retomando aspectos y características ya explicados en las primeras cinco "Tablas". Por lo tanto, con estas asociaciones que se hace de la sentencia aguda en la elegía y la sátira puedo solo confirmar que la agudeza está relacionada con la brĕvitās, con algunas costumbres y con géneros de la épica menor, es decir, con un estilo alto o aproximado a este, si se sigue la Rota Vergilii. A propósito de las costumbres y el estilo alto, me gustaría agregar que, al seguir el decoro cascaliano, se puede averiguar que la sentencia aguda es propia de personajes "viciosos", precisamente porque la sátira imita tales acciones. Sin embargo, no es exclusiva de estos, porque en la misma elegía hace uso de este tipo de sentencias y “esta Poesia las mas veces es morata" y no imita "vna viciosa, y vituperable action” como la sátira.

Como ocurre en la Philosophia, las sentencias agudas no se restringen a un tipo de estilo. De hecho, en la elegía se usan de forma general y este tipo de poesía "tambie[n] suele ser patetica" (pag. 304), porque trata de cuestiones fúnebres, además de "cosas mas ligeras" como "regalos y amores", que la volvieron "lasciua y amorosa" (pag. 303). Cascales no condena la lascivia de la elegía, por lo que interpreto que se refiere a temas eróticos derivados de la misma materia amorosa. De tal forma, no hay en ningún momento alusión a los vicios o acciones vituperables, sino a los "lamentos y quexas" (loc. cit.).

En breve, la agudeza no pertenece únicamente al hŭmŭlis stylus, pero no llega nunca al gravis. De hecho, la sentencia aguda -y en consecuencia la agudeza- no está presente en el género alto o

${ }^{277}$ Tal hecho se debe seguramente a que, en esta ocasión, como se observa en la edición de Brancaforte, Cascales sí sigue literalmente a Minturno, solo que simplifica los términos italianos de arguzia y acutezza (vid. id., p. 182, nota a la línea 20). Además, es posible que por inspiración del mismo texto de Minturno, Cascales haya definido que la sentencia de la elegía tenía que ser aguda, en concordancia con lo dicho en la sátira, aunque no hay forma de asegurarlo. 
épico, puesto que nunca se le menciona en dicha “Tabla" y se le restringe más bien a la épica menor ${ }^{278}$. Esta, sin ser totalmente hümŭlis, no llega al gravis stylus por la materia poética tratada. Por lo tanto, tal sentencia aguda se ubica entre el estilo mediocris y hŭmŭlis, que puede ser adornado con diferentes figurae elocutiones (vid. pag. 304). Con esto se entiende las implicaciones que la agudeza tiene en el ámbito de la ēlŏcūtı̌o poética.

Las últimas menciones de la agudeza, sin embargo, se emparentan más con la "metáfora de la punta”, sin llegar por esto a relacionarse directamente con el ingenio-como ocurre en el Cisne. En la "Tabla qvarta. De la Comedia"279, a guisa de conclusión de algunas observaciones de Castalio, Pierio afirma que los argumentos cómicos ofrecidos por Terencio y Menandro pueden ser materia para la creación de "differe[n]tes Comedias, y cada vno se podrà llamar dueño, y autor de la que hizo" (pag. 366). La ı̌mĭtātĭo renacentista aparece en las Tablas como método de creación poética, por lo que es una recuperación de modelos clásicos plenamente activa e innovadora. El mecanismo se concreta con una "prueua de ingenios" ${ }^{280}$, puesto que "la competencia es piedra aguzadera, donde se afilan los entendimientos, y caudales de cada vno" para evitar que algún "maleuolo me pueda acusar el hurto" (loc. cit.).

Para el humanista murciano, el entendimiento y los caudales ${ }^{281}$ se agudizan con la competencia, es decir con la "Disputa, contienda o concurréncia de dos o más personas a una cosa que se pretende" ${ }^{282}$. Tal término de procedimiento legal -así lo denotan los diferentes ejemplos ofrecidos en Autoridades- confirma que la convergencia de los ingenios -o bien la retractio-, creará una nueva obra, propia del poeta que imite al modelo clásico. Con esto es claro que la "prueua de ingenios" se refiere a la competencia y que esta, por traslātǐo, es la "piedra aguzadera", la piedra que afila. La agudeza es entonces adjetivo directo de la piedra e indirecto de la competencia, por lo que no son los ingenios en sí quienes agudizan los caudales, sino su encuentro agónico. En conclusión, el encuentro activo entre ingenios clásicos y modernos, por medio de la retractio, agudiza diferentes capacidades intelectuales como el entendimiento y el juicio, quienes se encargan de crear una nueva comedia a partir de un argumento ya utilizado y conocido ${ }^{283}$. Tales afirmaciones permiten que en las

${ }^{278}$ En este momento, me gustaría evidencias que la agudeza no se menciona en la "Tabla primera. De la Epopeia", lo que me permite relacionar esta ausencia con lo afirmado por Vgo en la Philosophia, para quien no era posible el uso de conceptos agudos en la épica.

${ }^{279}$ Para confirmar lo que he expuesto sobre el estilo al que se acerca la agudeza, Cascales elocuentemente calla el término en la "Tabla tercera. De la Tragedia".

280 A esta García Berrio llama agon de la retractio en su comentario y lo considera como la recuperación e innovación de los "consejos microestilísticos horacianos" que corresponden a los vv. 125-135 del Arte poética (vid. Introducción a la poética clasicista, p. 385).

${ }^{281}$ Entiendo caudal como la segunda acepción propuesta por Autoridades: "capacidad, juicio y entendimiento, adornado y enriquecido de sabiduría" (Diccionario de la lengua castellana..., s. v. caudal).

${ }^{282} I d$. s. v. competencia.

${ }^{283} \mathrm{Mi}$ lectura se distancia considerablemente de la propuesta por Víctor Fernández-Corugedo, quien de este pasaje concluye: "Cascales entiende por ingenio la agudeza de entendimiento" (El ingenio desde los presocráticos hasta Gracián, p. 285). El hispanista encuentra una equivalencia entre ingenio y agudeza de entendimiento que en realidad no 
Tablas se conserve una de sus principales directrices con respecto a la creación poética: partir siempre de los modelos y de la poética clásica para la innŏvāť̌o. De esta forma, se limita y subordina la capacidad inventiva por antonomasia del poeta, el ingenio. Sobre esto, sin embargo, profundizaré en el próximo capítulo.

En sintonía con el apego a la tradición clásica, en la misma "Tabla" el humanista murciano reitera la "ley del decoro" presente en los personajes propios de la comedia y cómo estos deben ser caracterizados. Evidentemente, los arquetipos descritos a continuación obedecen una tradición que se puede trazar desde el Aristóteles retórico. De tal guisa, en la poética se recupera una imagen ya fija en el inconsciente intelectual y cultural de la época cuando Castalio afirma que son "los Sicilianos, agudos" (pag. 384), dentro de su ēnüměrātı̆o de nacionalidades y cualidades. Pese a lo arquetípico del enunciado, se confirma que en las Tablas la agudeza está relacionada con ciertas "costumbres" tanto de un individuo, como de un grupo; luego, lo agudo especifica un modo de ser, de pensar y de comportarse. Sin embargo, precisamente por ser una serie de lugares comunes, no se dice si tal agudeza es intelectual o de carácter, aunque el texto permite al lector inclinarse por esta última ${ }^{284}$, con lo que me parece que se trata de una cualidad natural, que no implica ningún tipo de stŭdĭum o arte.

La agudeza continúa teniendo presencia en la "Tabla" dedicada a la comedia y adjetiva al tipo de risa que Cascales cree que es la que dicho género dramático debe buscar en el espectador. Siguiendo a Aristóteles (1449a 30-35):

sacamos que la materia Comica haze mouer a risa, y que la risa es vna burla sin dolor de alguna cosa torpe, y fea. No tomo yo la risa por aquel conte[n]to que recibimos qua[n]do encontramos a nuestro amigo, o hallamos buenos a nuestros hijos, y mujer, o quando nos embian algun presente: estotra es vna risa maliciosa, aguda, ingeniosa, fundada en la fealdad, y torpeza agena, assi de cosas, como de palabras. (pag. 388)

La risa cómica aguda nace luego de la turpütūdo ĕt dêformîtās, punto de convergencia entre la tradiciones clásica y renacentista como elocuentemente ha expuesto Margarete Newels ${ }^{285}$. Esta risa es también maliciosa e ingeniosa. Con esto puedo interpretar que, por un lado, se parte de una cuestión

está presente en el texto, primero porque Cascales no solo agudiza el entendimiento, sino también otros caudales y, segundo, tal agudeza de entendimiento es un resultado de un proceso específico, como ya he observado.

${ }^{284} \mathrm{El}$ resto de la enumeración se refiere a cualidades de carácter: "Conuiene pues tener noticia de lo que se [h]a escrito de diuersas gentes, y naciones, para pintarlos conforme a su opinion: dicen que los Griegos son naturalmente vanos: los Italianos, soberuios: los Sicilianos, agudos: los Franceses, leues: los Flame[n]cos, pacificos, y benignos: los Españoles, arrogantes: y los Africanos, cautelosos" (pag. 384).

${ }^{285}$ Vid. op. cit., p. 88-91. En estas páginas, la crítica también hace notar la deuda y la distancia que Cascales tiene con Pinciano, entre lo que cabe destacar precisamente los adjetivos usados por uno y otro: "Cascales dice que la risa es maliciosa, aguda, ingeniosa [...], epítetos que no encontramos en el Pinciano. En éste lo cómico de la comedia existe por sí mismo, por el regocijo y la alegría que provoca, que para él no parece tener nada que ver con la malicia ni con el ingenio. También el Pinciano subraya, desde luego, la virtud depuradora de la risa, pero los adjetivos con que Cascales y Rizo califican su concepto de la risa dan mucho más peso a la finalidad de enmienda y corrección que ésta persigue" (id., p. 89). 
natural -como se observa en la "risa que consiste en las obras" (pags. 390-391)- y, por otro, de un artificio que recae en la verba. Tal aspecto se aclara con el ejemplo dado por Castalio: los motes, que se forman a partir de equivocaciones, cambios silábicos, similitudes, alusiones y otros juegos verbales. En breve, la risa cómica es aguda como resultado de la descripción de las costumbres nuevamente una cuestión de èthŏs- o de la creación de artificios elocutivos, rēs o verba respectivamente. Sin embargo, no se puede decir que la agudeza participe de uno u otro o de ambos, ya que es el resultado, la risa, lo que es agudo. Por supuesto, se podría suponer que las cualidades del resultado corresponden o parten del método o materia para conseguirlo, pero el poco desarrollo que se le da estos no me permiten asegurar, por ejemplo, que los juegos verbales sean agudos para Cascales $^{286}$.

La agudeza volverá a estar en relación indirecta con el ingenio y directa con lo jocoso en la última tabla "De la Poesia Lyrica”. Aquí se explica que el soneto ${ }^{287}$, "vna composicio[n] graue, y gallarda de vn solo concepto, tratada co[n] cierto, y determinado numero d[e] versos", puede ser también "dulce, ingenioso, y agudo" (pag. 443) 288 . Dejaré para el capítulo correspondiente las razones que expone Castalio para llamar al soneto ingenioso ${ }^{289}$ y me enfocaré en recuperar ahora que es “agudo el Soneto en quanto pudiere ser, especial si es Epigramatico" (pag. 444).

El género agudo por excelencia, el epigrama, se relaciona con el soneto agudo. Sin embargo, esto no ocurre únicamente por la brěvĭtās que lo ha caracterizado desde la tradición clásica y en la que ya ni siquiera se detiene Cascales, sino también por la materia de la que parte: la jocosa. De hecho, para el humanista murciano el soneto es un "camaleón" que adquiere su color -stylus- de la materia que trata. Por lo tanto:

El Soneto es tal, que si la materia de que trata es Heroyca, sera Heroyco; y por consecuencia muy graue; si Comica, sera Soneto Comico, y humilde; si Tragica, sera Tragico y affectuoso; si la materia fuere jocosa, sera Epigramatico, y de necesidad agudo: si Satyrica, sera licencioso en palabras, y sentencias. (pags. 444-445)

${ }^{286}$ Así lo interpreta Fernández-Corugedo (vid. op. cit., p. 285). Por el contrario, me parece más probable que la agudeza califique la materia poética -una materia aguda-, pues, en las menciones anteriores, la agudeza se relaciona más con el èthŏs, que con una agudeza elocutiva. Incluso, el mismo Fernández-Corugedo, al recuperar las consideraciones sobre el concepto, concluye que "para el murciano el concepto representa en la obra literaria lo que la $\delta i \alpha ́ v o i \alpha$

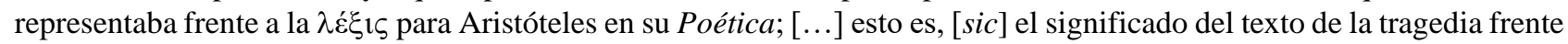
a las palabras" (id., p. 286).

${ }^{287}$ Desde ahora quiero recalcar que el rastreo de fuentes de García Berrio ha demostrado que Cascales se distancia de su hipotexto más importante, el Arte poetica de Minturno. Además, para su teorización recupera varios elementos de la tradición del soneto italiano desde Dante y del soneto español renacentista (vid. Introducción a la poética clasicista, p. 448-450), resaltando el carácter ecléctico de la poética dialógica.

${ }^{288}$ Se note que la agudeza se mantiene entre el mediocris y hŭmŭlis stylus, como en los géneros de la épica menor.

289 Sobre la primera característica del soneto, lo dulce, no ofrece ninguna información que pueda ayudar a dilucidar las características de la agudeza o del ingenio, sino que responde al dēlectāre poético (vid. pag. 443). De hecho, los tres adjetivos están tan diferenciados que pueden ser analizados de forma independiente, como se hace en el presente trabajo. 
El precepto es claro: la materia jocosa del epigrama y su brěvitās pueden ser aplicables al soneto, una forma métrica que puede tratar de varios temas y que es también breve ("cierto, y determinado numero d[e] versos"), para dotarlo de agudeza. Más adelante Castalio llama al soneto agudo epigramático, el que "no sera tan seco que no vaya vestido de las flores Lyricas, [et] sic de ceteris" (pags. 445-446). En otras palabras, para tal tipo de soneto se pueden disponer de las diferentes figuras elocutivas para su ornamento, pese a su brěvı̆tās. Ahora bien, no parece probable que tales ornamentos se refieran de alguna forma a las agudezas verbales de Gracián o similares, puesto que se ha dejado claro que la agudeza del soneto se debe a su materia epigramática y que el soneto epigramático (ya agudo) puede ser "vestido de las flores Lyricas". La agudeza está entonces enfocada en la rēs, el concepto en tanto materia poética.

La agudeza descrita en las Tablas poeticas posee un amplio espectro de acción, pero, sin duda, lo más característico es la recuperación de su ya canónica brĕvĭtās y lo más peculiar su empleo para connotar un tipo de èthŏs. Las cualidades de este, sin embargo, no son posibles determinar plenamente debido a la poca profundidad de las reflexiones ofrecidas por Cascales. Pese a esto, considero posible emparentar dicho èthŏs con la materia jocosa que determina el soneto agudo y circunscribirlo además en acciones que se mueven entre lo que era considerado humilde y mediocre - hŭmŭlis y médı̌ŏcrĭs styli. La agudeza del murciano, entonces, tiene implicaciones más bien en la rēs que en la verba, sin que por esto deje de lado su característica "puntiaguda" que obtiene de los juegos conceptuales para mover las emociones o que afila caudales a través del retractio. Por supuesto, en Cascales, como en los otros preceptistas, la agudeza juega un papel relevante en las cuestiones formales de la fonética y métrica. En pocas palabras, el término estudiado, con cualidades apenas esbozadas, permea la poética del murciano para entrelazarse en algunos, pero significativos momentos de los preceptos dirigidos bajo la "ley del decoro".

\section{POÉTICAS DISCURSIVAS}

Luis Carrillo y Sotomayor, "Libro de la ervdicion poetica" (1611)

La primera poética discursiva que analizo es el "Libro de la ervdicion poetica". Quiero recordar que tanto esta como la poética de Jáuregui son estructuralmente diferentes a las poéticas dialógicas. Por ello no hay un diálogo entre voces con diferente autoridad, sino una única voz. No obstante, dentro de la argūmentātĭo, Carrillo -como los autores de las poéticas dialógicas-considera en su reflexión varias posturas para enaltecer su propuesta: la poesía erudita. Existe pues un diálogo, pero no es explícito ni didáctico como en el corpŭs que hasta ahora he revisado. Además, dicho diálogo carrillesco también es con sus fuentes, porque el "Libro" también se caracteriza por su eclecticismo. 
Estas semejanzas me permiten utilizar el mismo método que hasta el momento he utilizado, excepto porque no hay que observar quién es el interlocutor que hace tal o cual afirmación.

Así pues, el término agudeza aparece catorce ocasiones a lo largo de los sesenta folios que componen el "Libro", un número bastante considerable si se piensa en la brevedad de esta poética discursiva. El número se vuelve aún más significativo cuando se advierte que en cinco ocasiones la agudeza es tal; es decir, es un sustantivo y no un adjetivo o adverbio como ha ocurrido la mayoría de las veces en las poéticas dialógicas. De hecho, en tres de tales menciones puede notarse el germen bastante desarrollado- de lo que se conoce como agudeza elocutiva. Aunado a esto, el resto de los pilares que conforman la erudición poética conformaran un texto que Antonio Vilanova llamó "la primera poética del Barroco y el primer doctrinal estético del culteranismo" ${ }^{290}$. La afirmación del hispanista no deja de tener validez al contrastarla con las poéticas anteriores y con el fenómeno poético de la época. Considero empero que es más propio darle un término que englobe la propuesta personal de Carrillo y Sotomayor. En otras palabras, un sintagma que exprese la motivación principal de su discurso y que considero ya está presente en el título del mismo: poética de la erudición, una poética que revisa las cinco causas aristotélicas de una producción poética basada justamente en la erudición.

Como se sabe, Carrillo retomó el concepto de erudición poética de la tradición herreriana y lo convirtió en su propuesta poética, a la que defiende con un intrincado repertorio de citas clásicas y glosas que fungen como probātiōnes de una argümentātĭo que abarca casi la totalidad de su "disputa" ( $M_{l}$ f. 110r) -como él mismo la llama. Ahora bien, las peculiaridades en torno a la erudición poética - o de la poética de la erudición-competen principalmente al concepto del ingenio, por lo que durante el “Capítulo III” las abordaré con más detenimiento. Por el momento, baste insistir en que la base de la poética de Carrillo y su propuesta teórica se encuentran en el título mismo. Además, con esto, el

290 "Preceptistas españoles de los siglos XVI y XVII", en Guillermo Díaz-Plaja (dir.), Historia general de las literaturas hispánicas, III, Renacimiento y Barroco, p. 649. La afirmación de Vilanova se puede considerar como el ápice de la crítica literaria que durante el siglo XX ha visto en la operă omnĭa del cuatralbo -principalmente en la Fábula de Atis y Galatea y en su poética- los antecedentes de la poesía gongorina, y, más aún, las bases de la así llamada poesía culterana (vid. Lucien-Paul Thomas, Góngora et le gongorisme considerés dans leurs rapports avec le marinisme, pp. 79-92; Justo García Soriano, "Don Luis Carrillo y Sotomayor y los orígenes del culteranismo", Boletín de la Real Academia Española, 1926, pp. 591-629; Marcelino Menéndez Pelayo, Historia de las ideas estéticas en España, II, Siglos XVI Y XVII, p. 358, nota 3; José María de Cossío, Fábulas mitológicas en España, pp. 300-307; Sanford Shepard, El Pinciano y las teorías literarias del Siglo de Oro, pp. 190-193; Fiorenza Randelli Romano, "Introduzione" a Luis Carrillo y Sotomayor, Poesie. I. Sonetti, F. Randelli Romano ed. y trad., pp. 46-50; Antonio García Berrio, Formación de la Teoría Literaria moderna, 2, Teoría poética del Siglo de Oro, pp. 138-184; Angelina Costa, "Introducción" a L. Carrillo y Sotomayor, Libro de la erudición poética, A. Costa ed., 1987, pp. 21-34; Rosa Navarro, "Introducción biográfica y crítica" a Luis Carrillo y Sotomayor, Obras, R. Navarro ed., pp. 46-78). Por supuesto, los juicios de los diferentes críticos son bastantes variados en cuanto a la distancia de Carrillo con la tradición petrarquista reformulada por Garcilaso y no son siempre positivos. Sin embargo, todos ellos coinciden en que los principios estéticos con los que se rige el joven poeta apelan a una nueva poesía, aunque su justificación se basa únicamente en las bases de la estética renacentista de raigambre clásica, con las figuras de Aristóteles y Horacio como principales guías. 
joven poeta se adhiere a una vertiente teórica más cercana al fenómeno poético aurisecular y a la nueva poesía inaugurada innegablemente por Luis de Góngora.

Antonio García Berrio llama a tal tendencia la "conciencia formal-hedonista del arte" y, pese a que el crítico no menciona la obra de Carrillo durante su digresión, considero que el "Libro" es un importante aporte para esta propuesta estética ${ }^{291}$. Mi afirmación no solo se basa en la presencia constante de ecos de las Anotaciones de Herrera -texto precursor de esta conciencia, según García Berrio $^{292}$ - y, en menor grado, del Cisne -poética inaugural de la misma ${ }^{293}$-, sino también en el desarrollo del concepto de agudeza, el cual se mueve específicamente en el ámbito de la èlŏcūtřo. Esta, sin embargo, no es puramente formal, sino que se relaciona intrínsecamente con el contenido que expresa. Joaquín Rodríguez Beltrán afirma a propósito que la figura retórica en los siglos XVI y XVII:

no es un mero ornamento, como si fuera un añadido prescindible, más bien, el hallazgo de una idea es inseparable de su equivalente hallazgo lingüístico. Se llega a un pensamiento particular precisamente porque se encontró cómo expresarlo agudamente. Esta profunda imbricación entre forma y contenido, lenguaje y sentido, es una de las principales constantes que se perciben en esta tendencia. ${ }^{294}$

En consecuencia, la élŏcutť̆o carrrillesca obedece a tal principio, lo que queda claro desde sus primeras afirmaciones: “Amigas son d[e]l ocio las Musas, y ellas madres del co[m]puesto hablar" (loc. cit.), donde conjuga la práctica de su elocución poética y el producto de esta. Así pues, el "co[m]puesto hablar" se convierte en la segunda preocupación principal de la poética y el concepto de agudeza es un punto de partida y un argumento para su desarrollo.

Tal y como ha ocurrido con el Cisne, el "Libro" tiene sus primeras alusiones a la agudeza con el término sutileza, mismo que se relaciona tanto con el estilo del historiador como con el del poeta:

El estilo pues (vsemos desta palabra) es los fines de entrambas à dos sciencias, este pues, aunque al principio inculto, y rudo, segun Scaligero en su historico, despues limado.

Este fue el primer genero de escriuir, escusa de nuestros principios, no solo en el que tratamos, sino en el que conuersamos, del qual supuesto que todas las cosas se comprehendan debaxo de necesario, prouechoso, y delectable, salieron diuersos generos de estilo, enderezados tan al comun blanco, como al otro. ( $M_{l}$ fols. $\left.113 \mathrm{v}-114 \mathrm{r}\right)$

Carrillo afirma que el estilo (ēlŏcūtı̆o) es el límite ${ }^{295}$ de la poesía y la historia, es decir, se circunscriben a este y, por lo tanto, lo identifica y define parcialmente, recalcando su importancia.

${ }^{291}$ Vid. Formación de la Teoría Literaria moderna. 2, pp. 440-481.

292 Id., pp. 440-441.

${ }^{293} I d$., pp. 446-447.

${ }^{294}$ Op. cit., p. 13. La 'tendencia' a la que se refiere es lo que llama "tendencia retórica y filosófica" del "estilo agudo" (vid. loc. cit.), que puede ponerse en sintonía con la "conciencia formal-hedonista del arte" de García Berrio.

295 Comparto la lectura de Rosa Navarro de "fines" como "límites" (vid. Luis Carrillo y Sotomayor, Obras, R. Navarro ed., p. 329, n. 27). Me baso tanto en la observación de la crítica que anota la palabra usada en la edición de 1613 ("mojones", $M_{2}$ f. 116v) como en la segunda acepción que aparece en Autoridades: "Se toma tambien por límite, a que se 
Además, con base en la poética de Escalígero ${ }^{296}$, específica que se debe trabajar para "limarlo", pues en principio es siempre "inculto, y rudo". Y, aunque aún lo dice, por los adjetivos usados, puedo inferir que el proceso de "limado" implica la erudición poética, que vuelve culto al estilo, pero también afilado e incluso agudo: la "metáfora de la punta" está presente.

Carrillo busca entonces un "estilo afilado", un "estilo agudo" -como el descrito por Rodríguez Beltrán-, que no es solo aplicable a estas disciplinas, sino incluso a la forma de hablar. De esta manera el cuatralbo no lo restringe dicho estilo al fenómeno poético, sino a una forma de comunicación y de transmitir conocimiento ${ }^{297}$. ¿Quiere esto decir que el "estilo limado" no es propio de la poesía? Si fuese así, no podría ser un elemento definitorio y no podría ayudar a la argūmentātĭo de la disputa. Sin embargo, la élŏcūtǐo es principalmente lo que Carrillo defiende de una poesía considerada como difícil y atacada en consecuencia.

¿Cómo podría interpretarse entonces el "estilo limado"? La respuesta a la cuestión se encuentra a continuación en la explicación aristotélica sobre la finalidad de cada "genero de estilo". La diversificación de estos - posiblemente dependiente del tipo y calidad del "limado"- ayuda a conseguir el dŏcēre ĕt dēlectāre de cada disciplina -“sciencias” como las llama el poeta. Así, pese a que la historia y la poesía tiene como límite un estilo perfectible a través del "limado", la poesía tiene un estilo agudo particular, con el que consigue además sus fines específicos. Por decirlo en términos aristotélicos, la causa formal (la èlŏcūtĭo) determina la causa final (dǒcēre ĕt dēlectāre) y a estas dos causas mira el estudio y la práctica de la erudición poética, en la cual interviene el ingenio, como se alude en la siguiente mención de sutileza.

El "Libro" continúa con los principios teóricos de la retórica y poética clásicas para afirmar que el estilo de la historia ya cultivado -"limado"- aseguraba su utilidad "por la necessidad, el senzillo hablar por el deleyte" ( $M_{1}$ f. 114r). Por otra parte,

Poesia deleytò tambien à los principios, no atreuiendose su osadia mas que à los Teatros, mejor imitadora (en aquella niñez suya) de la tosca suerte de aquellos tiempos, que de la sutileza de los nuestros, cobrò vigor con la edad, y con el exercicio conocimiento propio. De suerte, que à la historia se le quedò aquella sezilla manera de dezir, para contar las cosas hechas. La Poesia llamaron, porque no solo con bozes declaraua las cosas que huuiessen acontecido, sino tambie[n] las que no acontecieron, imitando como si fueran, como si pudieran ser, ò como deuieran forçosamente, ò con semejanza à verdad, como Aristoteles. $\left(M_{l}\right.$ fols. $114 \mathrm{r}-\mathrm{v})$

\footnotetext{
estrecha algún espácio o término. Latin. Terminus" (Diccionario de la lengua castellana..., s. v. fin). Por lo tanto, en el estilo se juegan las peculiaridades de la poesía y la historia, mas no es en sí mismo su finalidad, de la que habla en seguida.

${ }^{296} \mathrm{El}$ corrector de $M_{2}$ agrega la cita y traducción del pasaje aludido por Carrillo: "Uetus illud priscum rude incultum quod fui tantum suspicionem sine nominis memoria reliquit: Aquel antiguo y uiejo estilo, rudo, y descompuesto, que dexò de si solamente sospecha sin memoria de su nombre" (fols. 116r-117v). Navarro, además de aclarar la cita en latín, agrega que es la parte en donde Escalígero habla de las épocas y clases de poetas (vid. op. cit., p. 329, n. 28).

297 Décadas después Baltasar Gracián y Emanuele Tesauro diversificarían la agudeza de forma similar, volviéndola además de una forma de expresión, un modus vīvendi.
} 
La distinción entre historia y poesía de raigambre aristotélica confirma que, además de la causa material, el estilo es un punto de referencia para identificar a una u otra. Por tanto, aunque ambos estilos hayan pasado de un estado "rudo" a uno "limado", a la historia le corresponderá un estilo claro y a la poesía uno que pudiese representar algo más que "las cosas que huuiessen acontecido", razón por la que se debe alejar del habla del vulgo y, a su vez, de su entendimiento. Esto no está literalmente presente en este fragmento, pero se debe considerar que la erudición poética determina en sí misma un elitismo intelectual y creador.

Con respecto a la evolución de la ı̌mítăť̆o en la poesía, me parece oportuno considerar la interpretación que Shepard hace sobre la capacidad de representación de esta "sciencia". Para el hispanista, la glosa al pasaje de la Poética de Aristóteles (1460b13-17) -cuya fuente directa es la poética de Escalígero como $M_{2}$ lo indica ${ }^{298}$ - es el triunfo de la verosimilitud aristotélica sobre la realidad porque "la literatura no imita la naturaleza física, sino una segunda naturaleza en la que reina más lo posible que lo auténtico" ${ }^{\text {299 }}$. Comparto con el estudioso de Pinciano que Carrillo ve en la poesía el medio para imitar algo que va más allá de la naturaleza inmediata. Sin embargo, no me parece que esta "segunda naturaleza" pertenezca a la verosimilitud o al mundo de lo posible, sino, más bien, al topus uranus platónico. Mi lectura parte de la presencia en el "Libro" de una tradición mística que ve en el poeta a un ser elegido por una divinidad -aquí las Musas- que le permite acercarse a una verdad vedada al vulgo que no posee ni la capacidad ni el conocimiento para entenderla.

Para acceder a tal mundo ideal, es necesaria la sutileza que se procura con la experiencia y la práctica. Por supuesto, este tipo de poesía no obedece a una ı̌mĭtāť̌o cuyo fin sea el dēlectāre, presente en el teatro, "niñez" de la disciplina poética y "tosca suerte de aquellos tiempos". La "sutileza de los nuestros" corresponde pues a la edad adulta de la poesía y su causa final no es ya el deleite del público, sino el "conocimiento propio" ( $M_{l}$ f. 114r), aquel al que solo por medio de la creación poética erudita se puede acceder y el que deleita a los poetas por su carácter divino. El dèlectāre deja así de ser una función social.

Cabe agregar que la mencionada sutileza se refiere también al entendimiento y a la razón, capacidades del ser humano que, al igual que el ingenio, lo alejan de los animales y lo acercan a la divinidad $^{300}$. Así se aclara más adelante:

Todas las cosas en este mundo reconocen à la razon por suyo en el primer lugar, esta siempre es el Principe cuya voluntad es ley, pues no es sino la justa: que cosa mas hermana suya, que aparecer su centro qualquier cosa? obras son del entendimiento, trabajos del discurso: este

${ }^{298} \mathrm{Vid} . \mathrm{M}_{2}$ fols. $117 \mathrm{v}-118 \mathrm{r}$.

${ }^{299}$ Op. cit., p. 190.

300 Como señalan Angelina Costa y Rosa Navarro, Carrillo recupera la tradición clásica transmitida al Renacimiento con el filtro estoico de Séneca, uno de los escritores más queridos del joven poeta (vid. L. Carrillo y Sotomayor, op. cit., p. 331, n. 36; ID. Libro de la erudición poética, A. Costa ed., p. 52, n. 27). 
para las cosas altas, para las cosas sutiles, quanto mas nobles es que esta carzel del nuestro espiritu? ( $M_{1}$ f. 115 r)

Penetrar en las "cosas altas" y "sutiles" es trabajo del entendimiento, del que se dice que posee la “ciencia de contemplar" ( $M_{1}$ f. 111r) y la razón es quien preside todas sus "obras"; es decir, todo aquello que contempla y aquella que participa de la divinidad por sí misma ${ }^{301}$. La sutileza es, en otras palabras, la cualidad imprescindible tanto de las capacidades que quieren penetrar en una realidad más allá de la sensorial, como de aquellas "cosas" -entendidas como las rēs ciceronianas. A estas, además, se les contempla con dichas capacidades que se acercan a la divinidad al "afilarse". De esta forma se entiende en la primera mención literal de la agudeza.

Carrillo a partir del folio 114r inicia una de las principales glosas para argumentar tanto la superioridad intelectual del poeta como el carácter docto que debe tener su obra obtenida con la poética de la erudición. El fragmento glosado pertenece a un pasaje de Aristóteles cuya fuente precisa es desconocida ${ }^{302}$ y que es traducido de la siguiente forma: "Vnos animales, por ciertos indicios, y señales, aprendiendo de la naturaleza, discurriendo otros con socorro de la razon, lo que es prouable con el entendimiento alcançado" ( $M_{1}$ f. 114r). Se destaca así el entendimiento y su importancia para distinguir al ser humano de los demás animales y obtener razonamientos verdaderos a través suyo y de la razón (“Que mas verdadero?”, loc. cit.). Asimismo, el hecho de que se dependa del entendimiento para tal labor contempla la racionalidad presente en la poética de la erudición, lo que no dejará de asociarse a una cuestión irracional representada por las Musas y el favor que estas dan a los poetas eruditos.

Con base en lo anterior, el cuatralbo especifica que para llegar a los lugares altos se requiere de trabajo y estudio porque "harto nos ha enseñado la naturaleza, no a pie en juto, no sin trabajo se dexan ver las Musas, lugar escogieron bien alto, trabajo apetecen, y sudor” ( $M_{1}$ f. 118v). Entonces para su argūmentātĭo se vale como en otros momentos de las prŏbātı̌ones por autoritas (citas), porque "Bien apoyada queda con tantas razones la mia; bien aprouada la de los antiguos" ( $M_{1}$ f. $\left.118 \mathrm{r}\right)$. Dentro

${ }^{301}$ La razón al discurrir acerca de las cosas sublimes ya participa de Dios. Así lo expresa el poeta militar: "Teniendo muchas potencias el alma, junta con el cuerpo, con vna discurre, participa de Dios, porque es diuina, y contempla las cosas del cielo" ( $M_{l}$ f. 115r). Sin embargo, pese a que su naturaleza es en sí misma divina, para contemplar las "cosas del cielo" necesita del entendimiento, el cual se rige por un "ciencia", que implica su naturaleza "limable". En otras palabras, sin la sutileza, ni siquiera la divina razón podría contemplar y comprender los misterios del mundo por sí misma.

${ }^{302}$ Rosa Navarro anota sobre este pasaje: "No he conseguido localizar la cita. Aristóteles, en De anima, II, 3, 414-29, y III, 11-13, diferencia al hombre de los animales por poseer la facultad pensante y el intelecto. En De animalibus historia, donde subraya varias veces la similitud entre el hombre y los animales, dice: "A lo que en el hombre es arte, inteligencia, corresponde en algunos animales a alguna facultad natural del mismo género" (VIII, I, 588); y además en I, 1, 488, y IX, I, 608” (L. Carrillo y Sotomayor, "Libro de la erudición poética”, op. cit., p. 334, n. 42). 


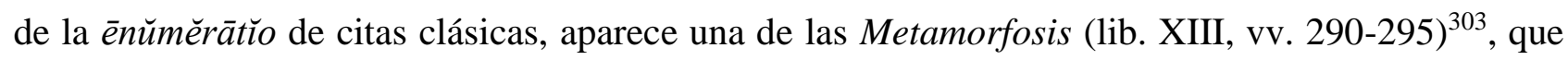
refiere la disputa de las armas de Aquiles entre Ulises y Ayax.

Carrillo introduce el pasaje de la siguiente manera: "Diuinos à este lugar (naturales en el) parecen estos versos del agudissimo Ouidio, atribuidos tan sabiamente à la persona de Vlisses" $\left(M_{1}\right.$ f. 118v). Los versos de Ovidio son divinos al ser vistos desde la perspectiva terrenal, pero en el alto lugar escogido de las Musas son naturales. En otras palabras, Ovidio, un poeta mortal, puede participar de la divinidad de las Musas con sus versos, los cuales consigue gracias a su cualidad de "agudissimo". Esta, además de calificar al poeta latino, parece corresponder específicamente a su entendimiento, porque es el punto de partida de la argūmentāť̌o de esta extensa glosa ${ }^{304}$. Tal capacidad humana, entonces, debe ser "limada" con el trabajo -'erudición'- para acercarse a la divinidad: sin la agudeza, el entendimiento no podría alzarse sobre el vulgo y penetrar en los secretos de las Musas.

Gracias a lo anterior, el poeta consigue la fama, misma que le garantiza la eternidad. Aunque para que los versos de los poetas consigan tal fin deben seguir una serie de características sĭne quā non sus creadores no podrán ser dignos del amparo de las Musas y dejarán de ser considerados poetas. El "Libro" deja de ser una disputa que defiende la poesía hecha con erudición poética y se convierte en un preceptiva rigurosa que establece lo siguiente:

Forçosa consecuencia serà pues, que la Poesia vsada de algunos modernos deste tiempo, siendo imitadora de los antiguos, serà la buena, y imitandoles se ha de tratar con su agudeza, elocuciones, y imitaciones, y no ignorar de todas las ciencias los puntos que se les ofrecieren: luego la Poesia fundada en contrario desto, no serà Poesia, pues en esto, (como se ha prouado) $s$ e diferencia el Poeta del Versificador ${ }^{305}$, si es, como es cierto, que no $s$ e pueden dar dos cosas en vn sujeto contrarias, y juntamente verdaderas. $\left(M_{l} \mathrm{f} .121 \mathrm{v}\right)$

Lo primero que se destaca en estas líneas es que los preceptos están destinados a los poetas “modernos deste tiempo". La intención de Carrillo es clamente influir en el fenómeno poético que lo circunda. En segundo lugar, la poética se basa en la ı̌mĭtātǐo ecléctica de los “antiguos", con lo que da continuidad a la estética renacentista, de la cual el cuatralbo sigue siendo representante, aún y con todas sus particularidades, entre las que se puede contar qué es lo que se debe imitar.

\footnotetext{
${ }^{303}$ Vid. id., p. 339, n. 62. Como indica su editora, en el "Libro" se cita con imprecisión y se indica que los versos son de "Ouidio lib. 3. Metamorphos" ( $M_{l}$ f. $118 \mathrm{v}$ i. m.).

${ }^{304}$ Los mismos versos citados mencionan literalmente al entendimiento: "Soldado rudo, y sin entendimiento / Vistiera de arte tanta obra gloriosa, / No supo del escudo varios lazos, / El mar, y tierras, ni del alto cielo / Las estrellas Cabrillas, y Virgilias, / Ni del mar jubilado el Arctos claro / Diferentes ciudades, ni de Orìon / Resplandeciente espada, y pida / Que se le den las armas que no entiende" ( $M_{l}$ f. 118v). La explicación abunda en la idea de que solo aquel que posea el entendimiento y la sutileza -contrario a lo rudo, como se explicó con el estilo- es digno poseedor de las armas de Aquiles, metáfora de los secretos divinos de las Musas, de los versos que los develan y de la eternidad que estos ofrecen.

305 Vid. $M_{l}$ f. $114 \mathrm{v}-115 \mathrm{r}$.
} 
Son tres los aspectos que Carrillo recupera de los clásicos: su agudeza, su elocución y sus imitaciones. Lo último puede referirse a la obra final o a su causa material (la tópica clásica); y si se considera esta última, entonces se pide que se imite su causa formal y material, pero ¿a qué se refiere con la agudeza de los antiguos? Con base en lo que hasta ahora he revisado -y ante la carencia de mayores especificaciones-, es bastante probable que se aluda a la "limadura" de sus capacidades y de su estilo, mismo que ya se encuentra presente en sus "elocuciones" (la "phrase" de las poéticas dialógicas). En otras palabras, se requiere al poeta que imite el método de stŭdiŭm que los clásicos han utilizado para "limar" sus capacidades intelectuales y que, a su vez, se ve reflejado en su estilo.

Aunado a lo anterior, el colega del cuatralbo debe tener presente las ciencias en tanto le sean requeridas para sus obras; luego, no debe conocer todo, pero sí poseer conocimiento sobre aquello que es versificado por su pluma. La ı̆mĭtăť̆o de los antiguos, en conclusión, consiste en técnicas potencialmente aprehensibles y perfeccionables y esto es suficiente para ser llamado poeta, de lo contario se es solo un versificador ${ }^{306}$. La causa eficiente, el ingenio o el furor, no son en ningún momento mencionados.

El poeta deja de ser alguien intangible y divinizado para convertirse en un ser artificial, cuya agudeza consiste en un método racional. Pese a esto, la agudeza de los poetas les permite acercase a las Musas y los vuelve sus protegidos; es decir, los diviniza. Dicho de otra forma, la agudeza -la "limadura" del entendimiento - diviniza al poeta y lo vuelve inmortal gracias a un estilo igualmente "limado", materializado en "sus poemas coronas" ( $\left.M_{1} \mathrm{f} .122 \mathrm{v}\right)$, siguiente punto de la argūmentātı̆o carrillesca.

Las subsecuentes menciones de la agudeza afianzan la interpretación anterior. Carrillo glosa a Lucrecio para defenderlo como poeta en oposición a la opinión de poéticas como la de Cascales. En consecuencia, aclara fragmentos de otros exégetas ${ }^{307} \mathrm{y}$, en aras de exaltar su dificultad, comenta los versos 6 y 7 del libro V De rerum natura: "Primero yo el saber grandes cosas / Enseño, y tambien quiero Religiones / Del animo apartar" $\left(M_{l} \text { f. } 123 \mathrm{r}\right)^{308}$. De estos versos, el cuatralbo admira cómo "Notable atreuimiento le dio el arte, pues con ella solo quiso confundir la cosa mas euidente de la naturaleza" (loc. cit.). Nótese pues que aquello que se exalta de estos versos son el atrevimiento y lo complicado de los versos, que dificultan la claridad de la naturaleza circundante.

\footnotetext{
306 No deja de ser notable que para Carrillo y Sotomayor no existen "grados de poetas", pues no se trata de mejores o peores poetas. Se es poeta o versificador y entre estos no hay intermedios.

307 A lo largo del "Libro" se alude a numerosos comentarios de humanistas italianos y franceses, principalmente Dionysius Lambinus, Beato Renato, Francisco Florido, Natalio Conti, Pontano y Poliziano. Tal despliegue de nombres, además de poner en evidencias las fuentes modernas de Carrillo, demuestran el principal móvil de su poética: la erudición. De tal forma que, además de citarlos como parte de su argūmentātǐo, entra en discusión con estos y los precisa como en este caso, donde advierte el "descuydo de Lambino" ( $M_{l}$ f. 122r) por no notar la corona poética de Lucrecio y despreciar otro pasaje del mismo autor latino por considerarlo claro, cuando no es así (vid. $M_{l}$ f. 121v-123r).

308 Rosa Navarro comenta las imprecisiones del latín y la identificación del fragmento (vid. L. Carrillo y Sotomayor, "Libro de la erudición poética", op. cit., p. 348, n. 95).
} 
El joven poeta justifica la obscūrittās de Lucrecio por las mismas auctoritates en las que el poeta latino basa sus versos. Además, su artificiosa èlŏcūtǐo proporciona deleite al público por la misma dificultad que en sí encierra y que critican sus detractores. Por esto, Carrillo expresa:

no mereciò estima Lucrecio, diremos (si seguimos la opinion co[n]traria de la nuestra) quien lo entendiera como deleytaràn versos, que acarrean consigo la necesidad de ta[n]to estudio obligacio[n] de ta[n]to cuydado, pues famoso ha sido, inmoratalidad ha sacado por justicia su nombre, à fuerça de sus estudios, bastele para elogio de sus obras auer merecido por conquistador de los agrauios. ( $M_{1}$ fols. $123 \mathrm{r}-\mathrm{v}$ )

La calidad de los versos se cifra a partir del stŭdiŭm requerido para su interpretación y su disfrute, por lo que, de no haber trabajado en esto, el receptor solo será un agraviante más. La complejidad de Lucrecio demuestra en el "Libro" cómo la fama poética se obtiene por medio de la erudición, misma que no puede ser perniciosa en ninguna de las causas, incluida la material, aún y cuando "Diran agudamente algunos, o inferiran (quie[n] lo duda?) del error de la opinion, quan poco acertado le fue al Poeta, ocupar sus versos en tan graue materia" ( $M_{1}$ f. 123v).

En esta cita, el adverbio agudamente es empleado porque se está refiriendo a la dignidad filosófica de una auctōrĭtās: "Plinio Filosofo" (loc. cit.), aún y cuando este ofrezca un juicio que demerita la obra de Lucrecio $^{309}$. En consecuencia, el entendimiento que este posee no es el mismo que el de los indoctos, pues ha sido limado con el estudio. Ahora bien, considero que el "Diran agudamente" está en relación con la capacidad racional predilecta del "Libro" porque las afirmaciones son hechas a partir de un proceso de inducción, pese a que provenga de la opinión, lo que provoca la falacia $^{310}$. De tal guisa, se habla agudamente cuando el entendimiento sea agudo, aún y cuando las conclusiones a las que se lleguen sean falsas ${ }^{311}$.

La preceptiva de Carrillo continúa enunciando su ideal de poetas eruditos, a los que llama "hijos de las buenas letras". Estos tratan asuntos graves como los que aparecen en el De rerum natura - de carácter metafísico- y en la épica, "pues dellos ente[n]demos lo q[ue] tratamos en este discurso, dexandole su lugar à la materia Lyrica, y Comica, diferentes en muchas partes desta" ( $M_{l}$ f. 124r-v). Se declara así no solo el objeto de esta poética discursiva sino también la poesía ideal de Carrillo, o, al menos, la causa material idónea. Hay que tener siempre presente que el "Libro" es una poética para pocos, por lo que el teatro - al que coloca además en los inicios de la evolución de la poesía- y

\footnotetext{
${ }^{309}$ Navarro nuevamente nota la falta de precisión en las citas de Carrillo, ya que este anota que el juicio desfavorecedor se encuentra en el libro 2, cap. 7 de la Naturalis historia que trata sobre los eclipses. Por el contrario, “al comienzo del lib. II dice que es una locura haber querido, como algunos, calcular las dimensiones del mundo y darlas a conocer, como lo es también -añade- querer salir de él y escrutar el exterior" (id., p. 349, n. 100).

${ }^{310}$ Recuérdese que desde el f. 114 r, Carrillo está glosando los métodos de raigambre aristotélica para llegar a la verdad a partir de los indicios (método empírico) y la razón (método dialéctico).

${ }^{311}$ Me parece importante señalar que este "Diran agudamente" es completamente diferente a los dichos agudos expuestos en las poéticas dialógicas, no solo porque sea la agudeza un adverbio, sino porque es producto de un proceso racional, desligado de cualquier cualidad cómica o mordaz.
} 
la lírica con sus temas predominantemente amorosos no pueden pertenecer en principio a la poesía erudita. Ambos géneros además están destinados a un público amplio y dependen del juicio de este - como ya bien advertía Lope de Vega.

Por ende, las auctoritates que fungen como prŏbātǐones para el poeta tratan "las buenas letras" y que "intentaron cosas, puestas tan en la frente (digamoslo assi) de la misma naturaleza" ( $M_{l} \mathrm{f}$. $124 \mathrm{v})$. En breve, se trata de poetas que develaron los misterios de la naturaleza y fueron más allá de los sentidos. No extraña entonces que Carrillo considera especialmente la doctrina de los estoicos y con base en esta inicie una nueva glosa, esta vez de las Metamorfosis de Ovidio ${ }^{312}$, a quien llama irónicamente "el facil, el llano" (loc. cit. $)^{313}$. Para demostrar los altos asuntos tratados por el poeta latino -mismos que involucran el "fuego artificioso" que los "Estoycos dicen ser dios" ( $M_{1} \mathrm{f}$. $125 r)^{314}$ - Carrillo glosa algunos pasajes de la Tebaida de Estacio, principalmente los versos 720-724 que traduce de la siguiente forma:

$\mathrm{O}$ à ver nuestros estragos diosa vienes

Del Pandionio monte, ò te diuiertes

Alegre en coros de la Ithon Aonia,

O en el Tridente Libico copetes

Peynado lauas, do el timo bramando,

De castas yeguas, que en ligero exe

Te arrebata. $\left(M_{l}\right.$ f. $\left.126 \mathrm{v}\right)$

Como ha hecho en ocasiones pasadas, el erudito poeta refuta o precisa las exegesis hechas por clásicos y modernos, entre los que considera especialmente el comentario hecho por Plácido Lactancio también conocido como Celio Firmiano Lactancio.

Al seguir los principios de la poética de la erudición, Carrillo no considera que Estacio sea oscuro en esta parte y por ello no merece la condena del público ${ }^{315}$. No obstante, hay un verso “Intemeratarum, volucer rapit axis equarum" (loc. cit.)- que ni siquiera los escolios de Plácido "allanaron", hecho que celebra el cuatralbo: "Discretissimo anduuo Firmiano, pues tuuo à mayor agudeza, como lo fue sin duda, no tocar el verso, que ofenderlo con alguna declaracion no tan

${ }^{312}$ Los versos comentados pertenecen al libro primero: "Despues q[ue] las semillas dese[n] boluio, y escura / Confusion desatò, por la otra parte / Del hueco el fuego resplandece claro. / Y sin peso escogio del alto alçar / Sumo lugar" ( $M_{1}$ f. 125r).

${ }^{313}$ Comparto la opinión de Angela Costa, quien observa en Carrillo una critica a la tradición humanista que tenía a Ovidio como un poeta sencillo (vid. L. Carrillo y Sotomayor, Libro..., op. cit., p. 66, n. 77). De aquí que después de llamar con tales epítetos a un autor que él mismo tradujo, ofrezca la opinión general que se tenía sobre este y en seguida inicie un complejo proceso de exegesis.

${ }^{314}$ En esta parte de la argūmentâtı̆o, el tono de Carrillo adquiere un matiz esotérico pues refiere las cuestiones divinas y místicas más intrincadas que son propias de los más doctos.

315 Se asegura en el "Libro": "digo à qualquiera que prete[n]diere desenlazar estas palabras, ellas mismas lo dize[n], y en esto confirma[n] ellas mismas lo que rehusan la ce[n]sura del vulgo" ( $M_{l}$ fols. 126v-127r). 
legitima" $\left(M_{1} \text { f. } 127 \mathrm{v}\right)^{316}$. Carvallo, que sí glosa el verso ${ }^{317}$, se dirige nuevamente con respeto a su auctōrĭtās y lo considera discreto, pero también agudo al reconocer su incapacidad para dar una explicación.

La agudeza es aquí un sustantivo y es además cualitativo, pues puede ser mayor o menor y la capacidad que posiblemente ayude a esta evaluación sea, precisamente, la discreción: "Prudéncia, juicio y conocimiento con que se distinguen y reconocen las cosas como son, y sirve para el gobierno

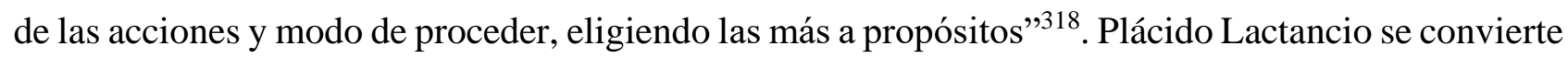
así en un punto de referencia para Carrillo, ya que el docto al "limar" su entendimiento, se vuelve discreto y resuelve qué es más agudo: comentar o callar la interpretación de un verso. En breve, la agudeza es resultado de un proceso racional y el stŭd̆̌mm procura su presencia.

En la mención anterior, la agudeza no tiene relación con la ēlǒcūť̌o, pero continúa aludiendo a aquello que es "afilado" y que permite discernir mejor entre las opciones posibles, volviendo al individuo discreto. Su siguiente aparición, por el contrario, sí implica la causa formal de forma metafórica y está presente en una de las numerosas traducciones del joven poeta. El "Libro" cambia de tópico y se lee:

Dexemos pues las historias, vamos à las palabras, segun Aristoteles, explicadoras de los conceptos, aun estas las negò el Principe de los Poetas à todos aquellos, no muy cercanos à las buenas letras.

$[\ldots]$

Cimothoe, y Triton con hierro agudo

Forcejauan. ( $M_{1}$ fols. $\left.127 \mathrm{v}-128 \mathrm{r}\right)$

Los versos son glosados por Carrillo para develar que solo los doctos pueden entender el sentido completo de las "buenas letras". Sin embargo, creo que esto también puede interpretarse de forma metafórica.

Como el mismo inicio del fragmento dice, las palabras se vuelven el centro de atención no solo para Aristóteles, sino también para Carrillo, quien utiliza la autoridad de Virgilio para aludir el carácter agudo que tales deben poseer, cual armas de guerra. Esto, sin duda, se vincula con el título

${ }^{316}$ La editora moderna del "Libro", Rosa Navarro, apunta: "Plácido Lactancio, en sus comentarios a la Tebaida, sólo anota de estos versos los términos Pandionio, Itone y Tritone; nada dice, en efecto, de los vv. 723-724" (L. Carrillo y Sotomayor, "Libro de la erudición poética", op. cit., p. 356, n. 122).

${ }^{317}$ La explicación, como la marginalia indica, posee un origen histórico: "Harpocracio[n] graue entre Griegos, Minerua, la que dixero[n] andar à cauallo, fue hija de Neptuno, y de la Ninfa Polifa, que tuuo por padre al Occeano, aquesta (como en el primero de Europa Manasias cue[n]ta) hizo vn carro: satisfizimos, entiendo, à los desseos de Papinio" ( $M_{1}$ f. 127r).

318 Diccionario de la lengua castellana..., s. v. discreción. Debido al contexto de la frase y de la terminología usada por Carrillo considero que la primera acepción es a la que se recurre en este fragmento, puesto que la segunda la identifica con la "agudeza de ingénio", binomio que no ha aparecido ni una sola vez en la poética. Por el contrario, podría considerarse como viable la tercera acepción que llama a la discreción "también la misma cosa hecha o dicha con agudeza, elección, sal o gracejo", porque es gracias a la agudeza de Firmiano que decide callar cualquier interpretación y, en consecuencia, es un discreto un "agudo y eloqüente, que discurre bien en lo que habla o escribe" (id., s. v. discreto). Pese a esto, prefiero privilegiar la primera acepción que justamente ayuda a precisar mejor el pasaje. 
de la poética: "LIBRO DE LA ERVDICION Poetica, ò lanças de las Musas contra los indoctos, desterrados del amparo de su deydad" ( $M_{1}$ f. 109r). Las "lanzas", también "hierro agudo", son armas cuya punta afilada penetra en la estulticia de los indoctos. Asimismo, dichas armas pueden referirse metafóricamente a las palabras de las Musas. Este adjetivo, entonces, inicia el desarrollo de la agudeza verbal que más adelante resulta fundamental para la poética de la erudición.

La agudeza en las siguientes menciones continúa aludiendo a las capacidades intelectuales afiladas de los individuos y a cómo dicha cualidad les permite ser superiores al vulgo, lo cual se manifiesta con su élŏcūtǐo. Por ello, después de glosar los versos de Virgilio ${ }^{319}$, asegura que existen individuos que pueden develar fácilmente sus ingenios gracias a las "buenas letras" y a los que se les puede considerar como sus "verdaderos sucessores". En consecuencia:

Huuo entre aq[ue]lla copia de illustrissimos ingenios en Roma vno, milagro de los demas, ò quando no, de los mas excelentes por lo menos, fue aqueste Craso, q[ue] bien conocio el lugar $\mathrm{q}[\mathrm{ue}]$ merecia, acerca della opinio[n] de los no muy doctos, hablando en su persona Ciceron, en el primero de oratore: Pues como pidiesse Magistrados, al rogar solia de mi apartar à Scebola, y dezirle, q[ue] queria ser impertinente. Esto era pedille mas bla[n]dame[n]te, lo q[ue] si no se hiziera impertine[n]teme[n]te no se hiziera bie[n]: necessitado el agudissimo varo[n] d[e]l fauor de sus personas, lisonjeaua co[n] la semeja[n]za de palabras à los oydos de los apassionados dellas. ( $M_{1}$ fols. $\left.127 \mathrm{v}-128 \mathrm{r}\right)$

Al inicio del diálogo Sobre el orador se refieren las palabras que Lucio Licino Craso enuncia a favor de la ars rhetorica, porque reconoce en esta el poder de la palabra "capaz de controlar el espíritu del público, atraerse sus simpatías e impulsarlos y hacerlos venir a donde y de donde uno quiera" ${ }^{320}$. Sin embargo, el fragmento que cita Carrillo aquí ${ }^{321}$ refiere las reservas que el político latino tiene con respecto al uso de la mera êlŏcūtǐo sin el talento natural ${ }^{322}$. En este contexto, Carrillo llama al político romano tanto ilustrísimo ingenio como agudísimo varón. El primero habla sobre la superioridad de su capacidad nata -como anotaré en el siguiente capítulo-, mientras el segundo hace referencia a la cualidad que le permite saber cómo lisonjear con ayuda de las palabras, para granjearse su favor, lo cual no depende de un talento natural, sino del stŭdŭum.

Esto lo considero a partir del mismo "Libro" y no tanto con ayuda de los preceptos ciceroneanos, ya que Carrillo hace nuevamente énfasis en el leitmotiv de su poética ${ }^{323}$ momentos antes de citar la obra de Cicerón. Por supuesto, ambos autores se refieren al talento natural -el

319 "Y dexando à Natal Comité, y Giraldo, syntag. 5 que sobre peyne entiende estos lugares, referiremos à Pedro Nanio Triton, Deidad de las olas, que en Griego Trito se dize, y Cimothoe. Estas dos Deidades las naues que encallaron libra[n], y de la fuerça de las aguas al mar bueluen facilmente" $\left(M_{l}\right.$ f. $\left.127 \mathrm{v}\right)$.

${ }^{320}$ Marco Tulio Cicerón, Sobre el orador, 1, 7, 30.

${ }^{321}$ Desde "Pues como" hasta "hiziera bie[n]" corresponde a id., 1, 24, 112 (vid. L. Carrillo y Sotomayor, "Libro de la erudición poética", op. cit., p. 358, n. 127).

${ }^{322}$ Esta afirmación la hace Cicerón en boca de Craso en Sobre el orador, 1, 25, 113-114.

${ }^{323}$ A saber: "no con facilidad se dexaran conocer estas cosas de los no muy verdaderos sucessores de las buenas letras" ( $M_{l}$ f. $\left.127 \mathrm{v}\right)$. 
ingenio- pero este no está relacionado directamente con la agudeza, en tanto que no se está "afilando" a la capacidad humana nata. Más bien, la erudición -llamada aquí "buenas letras"- es la que vuelve aguda a una capacidad racional como el entendimiento. Así, Craso se relaciona con el discretísimo Firmino, puesto que ambos pueden discernir correctamente entre las diferentes opciones de cómo actuar, y si el segundo sabe cuándo callar su desconocimiento, el primero conoce las palabras que agradan a los "apassionados dellas".

Con base en lo anterior, anoto que la argūmentāt̆̌o de Carrillo se concentra en la è más adelante, en la apología de la dificultad poética. Esto se presenta en lo que el "Libro" señala como el "Estilo de Poetas" ( $M_{1}$ f. 128r i.m.), el "Adorno de Poeta" (M $M_{1}$ f. 128v i.m.) y la "Licencia en sus palabras" ( $M_{1}$ f. 129v i.m.). Dicho de otra forma, en lo que respecta a las palabras es "la disposicion dellas, digo en su escogimiento" ( $M_{l}$ f. 128v) y el "curso del estudio" lo que le "obligarà à nouedad tanta variedad de tropos" (loc. cit.). Por ende, los principios de la dispŏsĭť̆o y la ēlŏcūtı̆o son impuestos por el stŭdŭum, que demuestra "su galanteria" (loc. cit.). Asimismo, este permite al poeta no solo escoger las palabras, sino también darles una "nueua disposición", una licencia poética más. Hay que recordar en todo momento -así como Carrillo mismo lo estipula en su poética- que todo esto se le permite al poeta docto, al que se nutre e imita las "buenas letras" de los antiguos.

Durante esta disertación, el joven poeta compara en todo momento el estilo del orador con el del poeta, así como el de la prosa y el verso. Para Carrillo, es evidente que existe una distinción entre ambos estilos, porque el orador depende de la aprobación del público y el poeta solo puede ser juzgado por sí mismo. No obstante, incluso el estilo del orador y el de la prosa deben ser "limados". Por lo tanto, si así ocurre en la prosa, "mas necesario serà sin duda al verso" ( $M_{1}$ f. $\left.130 \mathrm{v}\right) \mathrm{y}$, en consecuencia -con la autoridad de Quintiliano-, "no serà licito à las que no carecen de alguna obligacion de explicarse" ( $M_{1}$ f. 131r). Es pues incluso censurable a la poesía aclara sus "cosas algo escondidas" (loc. cit.), porque el trabajo de develarlas corresponde a un tipo específico de entendimientos. De tal manera:

dixeramos, sin saber el nombre, merecer este dicho vn tan agudo entendimiento como el de Erasmo: No me indigno si me ponen delante lo que no entie[n]do, pero huelgome se me ofrezca cosa que apre[n]da, efetos son del buen hablar dificultar algo las cosas. Esta costumbre tuuieron los antiguos, el mismo Erasmo. (Ml f. 131r)

Carrillo prescribe un agudo entendimiento como el de Erasmo ${ }^{324}$ no solo para comprender el "buen hablar", sino también para crearlo y lo contrapone al entendimiento oscuro del vulgo ${ }^{325}$. Por

${ }^{324}$ Como bien señala su editora Angelina Costa (vid. op. cit., p. 74, n. 113) y Marcel Bataillon (vid. Erasmo y España, p. 723, n. 31), la figura de Erasmo había comenzado a desaparecer poco a poco del ámbito intelectual español y Carrillo sería de los últimos testimonios que conservan la fama intelectual del humanista y que en el "Libro" se presenta como el arquetipo del entendimiento agudo, requerido para la erudición poética.

${ }^{325}$ Vid. $M_{l}$ f. $133 \mathrm{v}$. 
supuesto, la agudeza del entendimiento es producto de las "buenas letras" -la erudición-, mismas que aseguran conocer "cosas algo escondidas" que no pueden ser expresadas más que de forma difícil. Además, aquello que se puede penetrar con un agudo entendimiento ofrece un aprendizaje, por lo que no puede ser de ninguna forma censurable este tipo de élŏcutť̆o. Todo esto siempre justificado con las costumbres de los antiguos, a los cuales se insta a imitar.

Así pues, la agudeza está asociada al entendimiento, pero también a la ēlŏcūtřo, y esto, en la tercera sustantivación del término estudiado, adquiere importantes connotaciones para la poética posterior. Carrillo distingue entre oscuridad y dificultad, y desprecia a la primera para prescribir la segunda, asociada a la erudición. De esta forma:

No pretendo yo por cierto, ni nunca cupo en mi imaginacion lugar à aprouar la escuridad por buena, el mismo nombre lo dize, sus mismos efetos lo enseñan. No sigo al Preceptor, que dize Quintiliano respondio à su dicipulo ta[n]to mejor, ni aun yo lo entendi: Se quan abominable sea, y quanto mas à los mas agudos entendimientos, à los mas acertados oydos aquella templança, à los mas acertados oydos aquella templança persuado que Aristoteles, aquella que todos los que en este genero de exercicio, por su trabajo, y entendimie[n]to merecio lugar $s \mathrm{u}$ voto entre los primeros. Bien se, que le ha de vsar con discrecion en sus lugares, de las agudezas, ò dificultades que arriba he propuesto, mas que cosa no se ha de tratar con ella: bien se lo q[ue] aconseja en el cap. 21 el autor citado. ( $M_{1}$ fols. $\left.131 \mathrm{r}-\mathrm{v}\right)$

En este fragmento, se adjetiva una vez más al entendimiento con la agudeza, pues para Carrillo es esta capacidad la encargada de penetrar tanto en los secretos de las Musas, como en las obras de los poetas. Además, se apela a la mědǐcrcritāas aristotélica y a un uso templado de las licencias poéticas para evitar que la dificultad se vuelva oscuridad ("escuridad"), misma de la que incluso los agudos entendimientos huyen.

La poética de la erudición considera la ēlŏcūtı̌o diffičllis digna para representar los secretos que se revelan a los agudos entendimientos. La razón de esto es evidente: una ēlǒcūtĭo obscūrìtās es incluso incomprensible a los agudos entendimientos. No se puede acceder a los enigmas y barbarismos en los que se cae haciendo abuso de las "agudeza, ò dificultades" enunciadas por Aristóteles en el capítulo 21 de la Poética ${ }^{326}$ y descritas también sucintamente por el cuatralbo en su disputa (vid. $M_{1}$ fols. 128r-130v). Por consiguiente, en este fragmento las agudezas son dificultades elocutivas (figurae èlŏcūtı̌onis) o bien figuras retóricas (tropos), que deben ser usadas con "templança” y con "discrecion en sus lugares", es decir, con decoro ${ }^{327}$. Por primera vez en el "Libro"

${ }^{326}$ En este capítulo, como se sabe, Aristóteles desarrolla brevemente las figuras retóricas -entre ellas la metáforapero el capítulo en donde se habla del barbarismo y el enigma es el 22, por lo que se trata de una cita inexacta hecha por Carrillo, posible indicativo de que citara de memoria al redactar el "Libro".

${ }^{327}$ Por supuesto, el decoro carrillesco dista de equipararse a la rigurosa "ley del decoro" que gobierna las Tablas, porque, como avisa Vilanova el "concepto de oscuridad, exageradamente restringido, se reduce a los conceptos confusos y a los vicios de dicción, mientras que su defensa de la dificultad docta admite todas las características de hermetimo [sic] en los conceptos, diferencias en las palabras, y arcana comprensión que son propias de la poesía oscura" (op. cit., p. 644). La poética de la erudición exige entonces un decoro únicamente para evitar el exceso de agudezas, lo que no limita de forma alguna la dificultad docta con la que, de hecho, se cuenta. 
el sustantivo agudeza -nótese además que se encuentra en plural-alude a lo que más adelante Gracián llamará agudeza verbal, "que consiste mas en las palabras"328. El poeta docto que siga todos estos preceptos creará "buenos versos" ( $M_{1}$ f. 133r), comparables con las "buenas letras" que se imitan de los antiguos.

Como anoté, uno de los principales argumentos del "Libro" para negar la censura de la poesía erudita es que su valor no depende del vulgo, a diferencia de la oratoria. Precisamente sobre esta distinción vuelve Carrillo al final de su poética para enfatizar que "los q[ue] hablan emendada, y claramente"-los oradores-obtienen "virtud humilde, y pequeña en el Orador", mientras que es "vicio no humilde, y pequeño en el Poeta" ( $M_{1}$ f. 135v), porque la élŏcūtı̌o diffič̌lis no solo está justificada, sino que es incluso necesaria y obligatoria.

La prŏbātǐo de Carrillo para justificar este aspecto en particular es la figura de Horacio, del que cita los versos 364 y 365 de su Arte poética que, como se sabe, consideran la agudeza del juicio (vid. "Introducción”). El poeta traduce: "La cosa que no teme juicio agudo / Del juez, esta agrada, y agradara, / Vna vez, y diez veces repetida" (loc. cit.). Es decir, la poesía que no huye al juicio agudo es la que gana para el poeta la fama. Esta cita muestra que el juicio agudo-como el entendimientoes el que debe valorar la obra poética. Opino además que la agudeza de esta capacidad, siguiendo los principios carrillescos, se debe siempre al stŭd̆̌um.

El "Libro" muestra a continuación cómo dicho juicio funciona y su auctōritās es la Poética de Aristóteles, que distingue entre los yambos de Esquilo y Eurípides, y prefiere este último por su agudeza, visible en la palabra peregrina.

Que bien, mas qua[n]do no? Aristoteles enseñò la agudeza q[ue] auia menester la censura del Poeta, en la q[ue] hizo de Eschilo, y de Euripides: Eschilo, y Euripides en hazer el mismo, Yambo igualmente co[n] exemplo se muestran. Aqui desseo mas atento al lector: porque como estè vn solo nombre en lengua no trillada, en lugar de propio, ta[n] hermoso parecio como aq[ue]1 humilde. [...], para esto dessea el agudeza, con estas armas guarnece al Poeta Horacio, para que no rehuse la ce[n]sura del juez agudo y docto. $\left(M_{l}\right.$ f. $\left.136 \mathrm{r}\right)$

La cita del capítulo 22 de la Poética aristotélica se entrelaza con la reflexión de Carrillo, para ayudarle a probar que una poesía con agudezas no debe temer el juicio agudo. Las agudezas son precisamente las armas -como las "lanças" de las Musas- que permiten al poeta docto enfrentarse tanto a la cesura del vulgo, como a la crítica de aquellos que han "limado" sus capacidades racionales. Por supuesto, la agudeza que Aristóteles distingue ("enseñò") en Eurípides es el uso de un "solo nombre en lengua no trillada": una licencia poética que desautomatiza el lenguaje. El poeta docto se aleja del vulgo con las agudezas; estas determinan y caracterizan la èlŏcūtı̌o de la poesía erudita, realizada y pensada por y para una élite intelectual. Su importancia es por esto mismo capital para la poética de la erudición.

${ }^{328}$ Baltasar Gracián, Obras de Lorenzo Gracian. Tomo segundo que contiente La agudeza, y arte de ingenio, $\mathrm{p}$. 8. 
Las agudezas pueden ser cultismos, como el caso anterior, o bien cualquier impropiedad del lenguaje, como las que Carrillo admira en Virgilio. El poeta consigue este último tipo con el stŭdĭum, ya que nada dice que "n[uest]ra industria, y nuestro trabajo no nos ha de meter en possessio[n] de tan buenas sentencias, tan agudas impropiedades ${ }^{329}$, y de todo aq[ue]l (digamoslo assi) mueble necesario, à recebir en si ta[n] illustres dueños como las Musas" ( $M_{1}$ f. 139r). Por lo tanto, son todas "sus armas" (loc. cit.) elocutivas con las que el poeta gana la fama y hace frente a la censura de los "indoctos, desterrados del amparo de su deydad".

Como colofón, considero necesario enfatizar que la cualidad "afilada" de la agudeza se explota para calificar la forma en que las capacidades racionales como el entendimiento y el juicio se "liman" con la erudición, que es el stŭdı̆um y la ı̆mittăť̆o de las "buenas letras" de los antiguos -las auctoritates. Asimismo, esta agudeza racional repercute en el estilo del poeta, "afilándolo" y permitiéndole la creación de agudezas -figuras retóricas-, que permiten la distinción intelectual y estilística del poeta ante las otras artes y disciplinas. Se convierten, así, en un elemento característico y determinante del estilo poético. Además, la agudeza de Carrillo se asocia a los principios de Gracián y no solo en lo que se refiere a la agudeza verbal. En mi opinión, el mismo entendimiento agudo podría ya considerarse como un antecedente de lo que será la agudeza de concepto, que "consiste mas en la sutileza de el pensar, que en las palabras" ${ }^{330}$.

Juan de Jáuregui y Aguilar, Discvrso poetico (1624)

La obra de Jáuregui es la segunda poética discursiva de este estudio y la última que analizo del corpŭs. Se trata de un discurso a la manera italiana que se encuentra inmersa en la polémica gongorina y “Advierte el desorden i engaños de algunos escritos" (f. 1r). Está dividida en seis capítulos que explican las causas, los medios -novedades, metáforas, entre otros- y los resultados de los engaños de la poesía moderna (por ejemplo, la obscūrîtās). En tres de estos capítulos -el segundo, el quinto y el sexto- aparece explícita y únicamente cuatro veces agudeza: una como adverbio de modo y tres como sustantivo. La poca presencia del término con respecto a las poéticas dialógicas se debe principalmente al número de folios, ya que al considerar la frecuencia de la palabra en el Discvrso se descubre que esta es cercana e incluso superior a la Philosophia, el Cisne y las Tablas. Sin embargo, es evidente que, con respecto a la otra poesía discursiva, la importancia cuantitativa de la agudeza en el Discvrso es poca ${ }^{331}$.

${ }^{329}$ En $M_{2}$ se cambia “impropiedades" por “translaciones" (fols. 150v-151r), lo que deja en claro que se trata de tropos que ayudan a alienar el lenguaje común.

330 Baltasar Gracián, op. cit., p. 8.

${ }^{331}$ En promedio, en la Philosophia se menciona aproximadamente cada treinta y tres folios el término agudeza, en el Cisne, poco más de cada veinticinco folios y en las Tablas, casi cada veinte folios. Por el contrario, en el "Libro" la agudeza es mencionada cada cuatro folios y en el Discvrso tiente la misma frecuencia que en las Tablas. 
Aunado a la ínfima presencia de la agudeza en esta poética, se descubre desde su primera mención que el término en sí no es un concepto clave en el desarrollo teórico de la poética jaureguiana. Es, más bien, un tópico que refiere la capacidad "afilada" que poseen algunos individuos para ver más allá de las apariencias. Jáuregui extiende tal capacidad y se refiere con ella a quienes pueden encontrar los vicios en los que incurren los poetas modernos. En otras palabras, como ocurre en las otras poéticas, se explota la capacidad metafórica de la "punta", sin que por esto se trate de la “metáfora de la punta” teorizada por Rodríguez Beltrán. De esta forma, en el segundo capítulo de la poética, que trata de "Los engañosos medios con que se yerra", el poeta sevillano afirma:

I lo que mas dificulta el remedio, o le imposibilìta en tan desordenados excesos, es q[ue] quien los comete, no solo desconoce el error, mas le juzga virtud i le ama: yerra pensando que acierta: que es vicio mas pernicioso; como nota agudamente Quintiliano. (fols. 12r-v)

El poeta sevillano contrapone la agudeza de la auctōrĭtās latina a la ignorancia de los poetas modernos -a quienes se refiere en todo momento- para enfatizar cómo estos últimos, al alejarse de lo clásico, han dado la espalda al arte y al stŭd̆̌um de los modelos clásicos. La falta es notable, ya que estos junto a la gran fuerza de ingenio y la prudencia- son propios del poeta ideal de Jáuregui ${ }^{332}$. De hecho, como ha observado eruditamente su editora moderna, Mercedes Blanco, con el apelativo "moderno" Jáuregui connota no solamente lo "nuevo" de esta poesía, sino también su falta de atención al ideal clásico. Incluso lo acerca a lo medieval, con lo que reafirma su repudio y le resta cualquier valor poético a las obras "modernas" 333 .

${ }^{332}$ Vid. fols. 7r-v; sobre este fragmento discurro ampliamente en el "Capítulo III".

${ }^{333}$ Considero valioso transcribir a continuación la cita de Blanco, puesto que todos los matices que se recuperan de lo que Jáuregui llama "modernos" ayudan a comprender la contraposición que se hace aquí entre estos y el agudo Quintiliano, así como una parte de su teoría poética. La crítica afirma que la "noción de modernidad es utilizada por J. para calificar a los autores a quienes censura: 'disfraz moderno de nuestra poesía', 'manera de escribir moderna', 'estilo moderno', etc. se cuentan entre las descripciones perifrásticas que forzosamente debe usar puesto que se ha comprometido a no mencionar por su nombre a ninguno de estos autores. Al apodarlos 'modernos', J. indica que la manera de escribir que condena es de aparición reciente y que está en pleno auge, lo que le confiere importancia y urgencia, al tiempo que quita a sus fautores el peso y la autoridad que reviste entonces lo antiguo y bien asentado. Para apreciar las connotaciones del término, hay además que tener en cuenta que, a ojos de un hombre de cultura latina como J., 'modernos' es traducción de 'recentiores'y 'juniores', nociones que bajo la pluma [sic] los humanistas incluyen todo lo que para nosotros es medieval o moderno, o sea o [sic] posterior a la Antigüedad y más precisamente al mundo clásico. De ahí la resonancia negativa de la palabra: para los humanistas más importantes y típicos, como Petrarca, Erasmo o los Escalígeros, no cabe duda de la abrumadora superioridad de lo clásico sobre lo moderno, y además ellos asocian lo antiguo con la bella elocuencia, la alta civilización, y lo moderno con lo que es para ellos la barbarie de los siglos oscuros, de la escolástica, como puede verse también en Antonio de Nebrija. La aridez, tosquedad y vacuidad que imputan al lenguaje de las Escuelas se les antojan todavía más acusadas en el logicismo de la llamada via moderna, la de los discípulos de Occam. De ello se infiere que, para J., llamar 'modernos' a esos poetas a quienes otros (como Lope) llaman 'cultos' es una manera de negar su cultura y de sugerir su barbarie. Otra connotación negativa de la palabra, que también tiene incidencia en el texto de J., como veremos, es la que asocia modernidad y herejía, especialmente herejía protestante, como puede verse en el catecismo del Arzobispo Carranza, tan injustamente tachado de luterano: 'Los herejes modernos que, siguiendo a Martín Lutero, han negado la obligación de la confesión sacramental, hácenlo sin otro fundamento sino queriendo vivir licenciosamente, sin obligación a ley alguna que les pueda enfrenar las desordenadas pasiones de su carne y así no han de ser oídos, pues son herejes y declarados por tales' (Carranza 1972: II, 263)" (Juan de Jáuregui, Discurso poético, M. Blanco ed., n. 150, s. p.; disponible en línea: https://obvil.sorbonne-universite.fr/corpus/gongora/1624_discursopoetico\#body-1-1). Como puede observarse, las acepciones de la palabra "moderno" desde la época humanista son 
Con base en lo anterior y ya que el adverbio agudamente se refiere a la manera en cómo "nota" Quintiliano este gran defecto en los poetas modernos, considero factible afirmar que lo "afilado" de la metáfora se refiere a la capacidad que tiene la auctōrĭtās. Esta es capaz de ver entre los "excessos" poéticos el "error", que es la cacocelía "lo q[ue] excede allende la virtud" (f. 12v). No se dice más sobre dicha capacidad en esta mención; sin embargo, al seguir la teoría propuesta por Jáuregui en el Discvrso se puede suponer que se refiere al ingenio. Mi lectura se basa especialmente en la connotación que este último tiene como encargado de juzgar las obras poéticas (vid. "Capítulo III”).

Aunado al motivo anterior, a partir de otra auctōrĭtās -Ovidio-, Jáuregui considera que el ingenio también es el que tiene "mas duro afan" en dar los "primores ultimos de la lima" (f. 22v). Esto significa que dentro de sus funciones se encuentra también el "pulir" la versión final de la obra poética. La metáfora de lo agudo se sugiere sutilmente en este fragmento que involucra al ingenio. El hecho no sorprende dada la gran importancia que esta capacidad creadora tiene en el Discvrso (vid. “Capítulo III"), cuya fuerza permea incluso los pocos momentos en que la agudeza aparece.

Como ya mencioné, los capítulos que tratan de la frecuencia de las novedades y el vicio de la desigualdad -tres y cuatro respectivamente- no mencionan literalmente a la agudeza. Por el contrario, al inicio del capítulo $\mathrm{V}$, “Los daños que resultan, i por què modos", se afirma que los engaños observados agudamente por auctoritates como Quintiliano provocan "ofensas graves a nuestra patria, i lengua" (f. 23v). La cuestión de la lengua es de gran importancia en la argūmentâtĭo de Jáuregui, así como lo fue para una importante parte de la crítica contraria a la mezcla estilística, propensa a introducir "buena copia de peregrinas galas" (loc. cit. $)^{334}$. De tal guisa, se procuraba guardar en la medida de lo posible la gramática y el léxico nacional; es decir, el interés recaía en la búsqueda de lo que podría llamarse el decoro de la lengua nacional.

Dicho decoro, por supuesto, no niega en ningún momento el ornatus propio de la poesía, el cual, empero, debe emplearse mesuradamente -la médǐŏcrĭtās aristotélica. El ingenio exige "peregrinas galas", pero de forma moderada y, más importante aún, que no sea verba carente de sentido - rēs-, a lo que Jáuregui llama "vazio de las palabras" (f. 4v) o "furor del le[n]guage" (f. 36r). En otras palabras, es una acumulación de tropos que solo entorpecen el deleite y el sentido del texto, como reitera Jáuregui a lo largo del último capítulo de su poética. Lo anterior molesta principalmente al ingenio, debido a que la poesía moderna "olvida el valiente exercicio i mas propio de los ingenios de España, que es emplearse en altos concetos, i en agudezas i sentencias maravillosas” (f. 23v).

\footnotetext{
recuperadas por Jáuregui, quien las dota incluso de connotaciones religiosas, lo que se hace aún más evidente cuando el poeta usa metáforas precisamente religiosas para referirse a los errores de estos poetas que han equivocado el camino.

${ }^{334}$ Vid. Aurora Egido, "La hidra boca. Sobre la palabra poética en el barroco", Edad de Oro, VI (1987), pp. 9597.
} 
Sin profundizar ahora en las implicaciones que aquí tiene el término ingenio, es evidente que su cualidad receptora le permite ejercitarse y deleitarse en dos particularidades de la poesía: su rēs ("altos concetos") y su verba ("agudezas i sentencias maravillosas"). Estos, siguiendo lo dicho por Jáuregui en su "Introdvcion" a las Rimas, corresponden también al cuerpo y adorno:

imaginemos e[n] comun, que toda obra poetica, por pequeña que sea, se conpone de tres partes; alma, cuerpo, i adorno. I co[n]siderese primerame[n]te, q[ue] el alma, es el asunto, i bien dispuesto argumento de la obra: i quien errare en esta parte, no le queda espera[n]ça de algu[n] merecimie[n]to. Luego se adviertan la sente[n]cias proporcionadas, i co[n]cetos esplicadores del asunto, q[ue] estos dan cuerpo, dan miembros i nervios al alma de la conposicion. Vltimamente se note el adorno de las palabras, q[ue] visten esse cuerpo co[n] aire i bizarria. ${ }^{335}$

Sobre el alma de la obra se trata poco en el Discvrso; sin embargo, sí hay una especial preocupación en que los "co[n]cetos esplicadores del asunto" sean justamente "altos concetos" 336 .

Aunado a lo anterior, considero que en esta adjetivación está implícita de cierta forma el alma poética, porque la existencia del decoro entre alma y cuerpo asegura que la calidad del asunto tratando participe tanto de la rēs como de la verba. Por su parte, las sentencias representan el cuerpo y las agudezas el adorno, que pueden ser unificados bajo el término de la verba latina. Entonces, las agudezas para Jáuregui son el ornatus de la obra poética, o bien, los tropos -las figurae elocutionis. Esto no lo distancia mucho del sentido que se les da en el "Libro"; de hecho, por la relación que tienen con el resto de los elementos poéticos, se puede afirmar que corresponden de igual forma a las agudezas verbales, mismas que deleitarán a los “ingenios de España”.

Ahora bien, más adelante se agrega: “estas, por su dificultad, se rehúsan, i se pretende suplirlas con solo rumor de palabras" (f. 23v). No se especifica si "estas" se refiere únicamente a las "sentencias maravillosas" o es extensible a las "agudezas". Pese a esto, por lo que expliqué anteriormente, entiendo que se refiere a ambas y no a los "altos concetos" -sintagma masculino. Jáuregui alerta nuevamente sobre la tendencia a que la verba sea sustituida con "rumor de palabras", porque -es importante señalar- las agudezas son difíciles de hacer y entender. Por tal motivo, su presencia en la poesía debe ser moderada, aunque imperativa ya que de tales agudezas depende también la dignidad poética.

A partir de lo anterior, opino que es importante enfatizar que las agudezas no son solo palabras como se reafirma en la siguiente mención. Así, mientras al "rumor de las palabras" recurren los poetas modernos, quienes "reducen la importancia i el ser de su poesia al desgarro i braveza de locuciones i vozes: barata gala" (f. 26v), el poeta prescrito en el Discvrso usa en sus obras "sentencias valiosas,

335 “Introdvcion", Rimas, s. f.

${ }^{336}$ A lo largo de su poética, el poeta adjetiva de diferentes formas estos "concetos", pero siempre de forma positiva para dejar en claro la importancia de que estos guarden una rēs sustanciosa, alta y sublime (vid. fols. $4 \mathrm{r}, 23 \mathrm{v}$ y $31 \mathrm{v})$. 
de agudezas i concetos preciables. este [sic] adorno còmprase caro" (loc. cit.). Los tres elementos poéticos antes mencionados se repiten nuevamente y se enfatiza el trabajo que debe empeñar el poeta para conseguirlos. Y quien no pueda hacerlo quiere "disimular su pobreza con algun aparato engañoso de galas relu[m]brantes i falsas" (loc. cit.). En ambas menciones Jáuregui considera que alma, cuerpo y adorno pueden ser manipulados por el poeta moderno y sustituidos por locuciones vacías. Esto, expresado de diferentes formas por la vărīāť̆o y amplĭficātǐo barrocas, es el principal engaño denunciado a lo largo del Discvrso. Sin embargo, pese a la gran insistencia sobre la verba vacía de los poetas modernos, solo en estas dos ocasiones durante el capítulo quinto se mencionan las agudezas. ¿Es posible que utilice un sinónimo para referirse a estas? Para sus críticos parece que es así.

Según Mercedes Blanco y Juan Matas Caballero, la agudeza puede estar implicada en el término concepto, definido por ellos como un pensamiento o dicho agudo ${ }^{337}$. No obstante, en el Discvrso no hay ningún indicio que permita llegar a esta conclusión y, menos aún, identificación. De hecho, gracias a la referencia que hace Jáuregui en sus Rimas y a partir de lo que se dice del concepto en la poética, este no es más que el cuerpo del poema -que puede también considerar el alma gracias a su adjetivación. A este se llega gracias al ingenio, por lo que Jáuregui observa que son "concetos de ingenio" (f. 23v) -conceptos concebidos por el ingenio.

Asimismo, hay que recordar que el ingenio y la agudeza se han acercado en la poética únicamente por la capacidad del primero para penetrar en los errores y por la cualidad de "lima" que puede tener en la èlöcūtı̆o poética. Tales interpretaciones, no obstante, solo se pueden conseguir explotando la metáfora de lo agudo porque en ningún momento se dice que el ingenio se "afile". En conclusión, el ingenio es el que procura y recibe el concepto. Así pues, este, como recuerda Antonio Carreira, "no es más que un participio subsufijo del verbo concebir: ‘lo concebido’”,338. En conclusión

${ }^{337}$ La hispanista en una amplia cita sobre el conceptismo en España, considera primero ambos términos de forma separada, pero más adelante afirma que los detractores del gongorismo como Jáuregui acusan a este de manierismo porque no posee "conceptos (pensamientos ingeniosos y agudos), ni sentencias (ideas filosóficas o de alcance general) o que, si los había, no eran lo bastante «altos» y «maravillosos». Lo acusaron por consiguiente de palabrería insustancial. Pero se trataba de un argumento polémico contra un hombre, no de un principio estético opuesto a otro" (J. de Jáuregui, Discurso poético, M. Blanco ed., n. 312, s. p.). Por su parte, Juan Matas Caballero, con base en la afirmación de Andreé Collard, opina que el concepto en el poeta sevillano debe ser leído de la misma forma que en Lope: “"dicho agudo y sentencioso' o 'pensamiento profundo' (lo que hoy se diría concepción: del mundo, de la vida, etc.)" (Juan de Jáuregui. Poesía y poética, p. 241, n. 85). Como puede apreciarse en ambas posturas, el término concepto es más bien amplio, lo que demuestra la riqueza de connotaciones que tuvo en los Siglos de Oro. Sin embargo, si se aplican a un escritor específico estas definiciones sobre el concepto, que procuran abarcar cada sutileza del término, la interpretación del mismo puede volverse inexacta. Por esto, antes de considerar la denotación general del texto analizado, es importante primero develar las connotaciones con las que le dota no solo cada autor, sino la obra en particular, debido a que aún a lo largo de la ŏpěra omnĭa de un mismo autor se pueden notificar variantes significativas en términos tan complejos como lo son el concepto y la agudeza.

338 "El conceptismo de Góngora y el de Quevedo", p. 361-362. 
y siguiendo los principios del Discvrso, considero inexistente la relación del concepto con la agudeza o las agudezas, que son los adornos -la verba.

En los últimos folios de su poética, en el capítulo sexto, Jáuregui discurre sobre " $L a$ obscuridad, $i$ sus distinciones" y encumbra la persp̌̌cŭŭtās con la ayuda de la auctōrîtās de San Agustín (De doctrina christiana, IV, 11) ${ }^{339}$. En este, el poeta sevillano reconoce la capacidad de la agudeza: "De què sirue (dize el mismo Agustino con su agudeza) de que sirue 340 una llaue de oro, sinò abrimos con ella donde queremos?" (f. 38r). Aquí, el término que analizo se encuentra en singular y está semánticamente relacionado con la primera mención, porque se refiere a la capacidad receptora de San Agustín, pero no solamente.

Esta auctōrițās, propia del canon católico, tiene agudeza primero porque comprende la necesidad de equilibrio entre rēs y verba, que asegura la perspǔcŭitās para el ingenio receptor. En segundo lugar, es agudo por la manera metafórica en la que se ha expresado. En otras palabras, como ya había ocurrido con la primera mención de agudeza en la Philosophia, el individuo agudo es capaz de relacionar dos elementos para comunicar de forma eficaz, sin descuidar los ornamentos propios de un estilo alto. Sin embargo, a diferencia de la mención de Pinciano y de la primera analizada en el Discvrso, la agudeza no es un adverbio de modo, sino que es un sustantivo. ¿Significa esto que la agudeza se convierte en una capacidad humana en sí misma? Si esto fuese así, la agudeza tomaría el lugar del ingenio, puesto que percibe una verdad, establece relaciones y crea incluso galas de ingenio $^{341}$.

Aunque es una posibilidad, descarto lo anterior. La agudeza no es un término lo suficientemente presente en la poética para que pueda tener la misma importancia que el ingenio. Además, es la única ocasión en la que se le sustantiva de esta forma, por lo que no se puede establecer una sinonimia entre agudeza e ingenio, como sí ocurre entre este y el entendimiento (vid. "Capítulo III"). En consecuencia, me parece pertinente determinar que esta mención obedece más a un fenómeno metonímico, en donde una característica del ingenio se sustantiva: la agudeza. En otras palabras, la agudeza de esta mención se encuentra efectiva y semánticamente relacionada con la primera. Jáuregui se refiere entonces indirectamente a la causa eficiente, capacidad que sin lugar a dudas es privilegiada en el Discvrso.

Antes de concluir, es oportuno reflexionar sobre la poca presencia que la agudeza tiene en el Discvrso. La necesidad de esto surge tanto por su poca participación en la teoría jauriguiana como la distancia que esta tiene con respecto a la otra poética discursiva analizada, el "Libro". Así pues, es

${ }^{339}$ Vid. J. de Jáuregui, Discurso poético, M. Blanco ed., n. 403, s. p.

${ }^{340}$ Es oportuno señalar esta repetición "de què sirue", ya opino que en ella puede adivinarse, más que un elemento retórico, uno prosódico. Un posible indicativo de que el carácter discursivo de la poética haya sido también llevado a cabo en la actio.

${ }^{341}$ Sobre estas características del ingenio profundizaré en el "Capítulo III". 
cierto que en ambas ya está presente como sustantivo y en ocasiones las connotaciones que se le dan se aproximan: es una característica "puntiaguda" de una capacidad humana y es también una figura retórica. No obstante, es innegable que Jáuregui evita el término agudeza por una razón en particular. Me refiero al equilibrio imperante entre la rēs y verba: el decoro que prima en los folios de la poética y que intenta evitar cualquier tipo de desigualdad -tal y como se analiza en el capítulo cuatro del Discvrso.

En respuesta a lo anterior, Jáuregui alerta contra lo que representa la "metáfora de la punta"; es decir, aquello que conlleva un desface entre el contenido y la forma, con lo que se pone a prueba tanto la agudeza del creador como del receptor ${ }^{342}$. Con esto no pretendo insinuar que Jáuregui apueste por una poesía llana o fácil, pero sí que posea la virtud de la perspǔcŭı̆tās. Incluso, me parece que el poeta sevillano considera la "amenaza" que pueden representar las agudezas en el capítulo tres, en donde afirma que todas "las novedades poeticas, i osadias de eloquencia, aunque se acierten, son de su naturaleza culpas o vicios" (f. 14v). Y solo ingenios como el de San Agustín pueden usarlas sin caer en un grave pecado. Dicho en otras palabras, para evitar el vicio, Jáuregui calla lo más posible el término agudeza, al igual que Cascales calló en su momento el ingenio (vid. "Capítulo III").

Como colofón a este análisis, añado que Jáuregui recupera la connotación “puntiaguda” de la agudeza y la atribuye a la capacidad del ingenio, lo que recuerda sin duda a la agudeza de ingenio de Huarte de San Juan y Carvallo. Además, al igual que Carrillo, el término significa figură elocutionis cuando aparece en forma de sustantivo plural. De esto último depende principalmente que se no se le mencione constantemente, debido al peligro que la agudeza supone en sí misma para el decoro jauriguiano. Sin embargo, esta misma preocupación de no reiterar el término evidencia la gran aceptación y uso que ya tenía en la práctica poética.

${ }^{342}$ No se olvide que sobre esto trata Joaquín Rodríguez Beltrán, de quien tomo el término de la "metáfora de la punta" para referirme a la agudeza y sus características (vid. op. cit., pp. 13-24, principalmente). 


\section{CAPÍTULO III \\ INGENIO EN CINCO POÉTICAS ESPAÑOLAS DE LA SEGUNDA MITAD DEL SIGLO XVI Y PRINCIPIOS DEL XVII}

A lo largo del presente capítulo reviso el segundo término que ocupa el presente trabajo: el ingenio. Para esto procedo de la misma forma que en el "Capítulo II" dedicado a la agudeza, por lo que analizo en primer lugar las poéticas dialógicas y posteriormente las discursivas.

\section{PoÉTICAS DIALÓGICAS}

\section{Alonso López Pinciano, Philosophia antigva poetica (1596)}

A lo largo de las trece epístolas que integran la Philosophia, la palabra ingenio aparece literalmente treinta y tres veces, aunque está también presente cuando se desarrolla el término furor principalmente en la "Epistola tercera". Esto evidencia la tradición neoplatónica y la teoría huartiana que nutren la poética escrita a manera de diálogo humanista. Asimismo, al seguir el método ecléctico propio de la época, algunas connotaciones que López Pinciano da al ingenio responden a la tradición aristotélica y horaciana, como señalo en su momento.

La primera mención del ingenio se encuentra en la "Epistola primera, o introduction a la Philosophia antigua". Aquí, como parte de una de las largas digresiones filosóficas tan características de esta poética -en especial de la epístola introductoria-, se explica la parte animal e intelectual del ser humano, las cuales están conformadas por potencias $^{343}$. De tal guisa, la parte animal se divide en sentido, movimiento y apetito. Dentro de la definición de estas, la primera se diferencia del entendimiento, potencia de la parte racional e intelectual humana a la que se liga el ingenio conforme a la tradición (vid. "Introducción"). Se aclara que mientras el sentido "muestra su acto con instrumento corporal", el entendimiento "libre y suelto del tal instrumento, haze su operacion; q[ue] la alma suelta y libre del cuerpo" (f. 15). A partir de esto, Pinciano personaje -la voz que personifica al neófito curioso- pregunta a sus interlocutores si acaso no "es vn hombre mas ingenioso que otro, sino por causa del celebro bien, o mal dispuesto, q[ue] las almas, segu[n] nos predican en esos

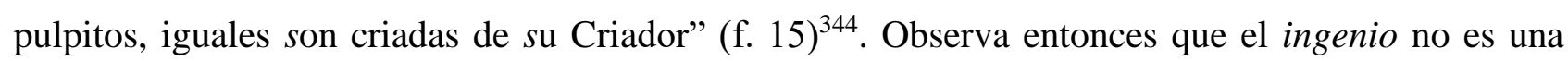

${ }^{343}$ Aunque no es mi intención analizar esta compleja clasificación, creo que es importante tenerla presente grosso modo para el desarrollo de las primeras menciones del ingenio. En consecuencia, se debe saber que Pinciano llama también e indistintamente a dichas potencias sentidos o facultades. Estas se dividen en potencias animales y potencias racionales o intelectuales. Las primeras son sentido, movimiento y apetito. A su vez, el sentido está conformado por cuatro potencias interiores -sentido común, imaginación, estimativa y memoria- y cinco exteriores -vista, oído, olfato, gusto y tacto. Por su parte, las facultades racionales son entendimiento. memoria y voluntad.

${ }^{344}$ Tal pregunta se acerca al postulado inaugural de las Institución oratoria de Quintiliano: "Vengo bien en que uno aventaje en el ingenio a otro; pero esto será para hacer más o menos; mas no se encontrará ni uno solo en quien no 
cualidad general en el ser humano, sino que se manifiesta "cualitativamente" diferente en cada individuo, según de una determinada capacidad fisiológica.

Es evidente que este cuestionamiento tiene sus bases en los presupuestos huartianos a propósito de la disposición natural del cerebro. Sin embargo, Fadrique -la voz más autorizada de la poética- desmiente esto y opta por una explicación neoplatónica. En los seres humanos, la calidad del entendimiento - $\mathrm{y}$ en continuidad el ingenio - se debe a que el alma, cuando entra al cuerpo (la “casa de barro"), pierde su 'memoria', de aquí que se escuche a "algunos Philosophos dezir, que el saber, era como vn acordarse" (f. 16). Con base en esto, se puede establecer que el ingenio es de naturaleza incorpórea y por lo tanto pertenece a la parte racional e intelectual del ser humano. Además, con la pregunta de Pinciano personaje, se insinúa que el ingenio forma parte del entendimiento, capacidad que ayuda a ver y a distinguir las cosas, tal como lo indica Fadrique con la siguiente compărātı̆o: "como el que entra en algun aposento algo escuro, al principio no vee cosa alguna; pero despues va viendo y distinguiendo las cosas" (loc. cit.).

Ahora bien, al explicar la imaginación, una de las cuatro potencias internas del sentido, se dice que esta, al igual que el furor, pide calor con sequedad. Alonso López Pinciano sigue a Huarte de San Juan tanto en la cuestión de los humores como de la sutil relación con la imaginativa. Es oportuno anotar que, contrario a lo propuesto por Fernández-Corugedo ${ }^{345}$, en esta digresión no hay relación entre ingenio y furor, hecho que incluso develaría desde el comienzo una contradicción por parte de Pinciano. Recuérdese que anteriormente se sugirió que el ingenio pertenece al entendimiento, el cual no necesita una disposición especial por parte del cerebro, mientras que así lo requieren la imaginación y el furor. Estos, por otra parte, están implicados en la producción poética, porque "El instrume[n]to desta facultad [la imaginación] pide calor con sequedad compañeros del furor, a cuya causa es vn sentido muy co[n]uenie[n]te para la poetica" (f. 22).

Con base en lo anterior, observo cómo el furor se acerca a la poesía y el ingenio -por su cualidad inmaterial- se aleja de la misma. De hecho, más adelante, Fadrique habla sobre el ingenio y el arte que enseña la obra del filósofo musulmán Avicena, quien, empero, no dejó de lado la imaginación, ligada a la superstición y la credulidad, o sea a lo falso. Pese a esto, Avicena no deja de ser una auctōrĭtās para Fadrique:

todos los hombres extremados en alguna obra de virtud, son de mi en mucho tenidos, y yo les soy muy afficionado, fue Auicena autor graue, y que en sus obras enseña mucho ingenio y

\footnotetext{
se consiga algo a fuerza de estudio" (Institución oratoria, I, 1, trads. Ignacio Rodríguez y Pedro Sandier; disponible en línea: http://www.cervantesvirtual.com/obra/instituciones-oratorias--0). Es bastante significativo que la primera mención del ingenio en la Philosophia tenga tal relación con una cita en donde el stŭdŭum juega un papel importante para la "obtención" de la capacidad.

345 "Nada dice Pinciano, por cierto, del ingenio en esta primera epístola como no sea que entienda por furor e ingenio lo mismo" (El ingenio desde los Presocráticos hasta Gracián, p. 266).
} 
arte: confiesso, que como todos los demas de su nacion algo fue tocado de la supersticion y credulidad, y assi lo es en esto de la imaginacion. (f. 23)

Aquí, además de distanciarse de cierta forma de la tradición musulmana y pagana, es nuevamente notable la separación entre ingenio e imaginación: el primero es tenido por racional y verdadero, mientras que de la segunda se duda. Por el contrario, sí se considera por primera vez en este análisis la relación contigua entre ingenio y arte. Pinciano, ateniéndose sin duda a la poética horaciana, determina que este binomio puede ser enseñado $\mathrm{y}$, a su vez, aprendido ${ }^{346}$.

Asimismo, el arte, junto al entendimiento, es identificado como un hábito intelectual que puede ser perfeccionado y que "es habito de efectuar con razon verdadera" (f. 37). Estos hábitos intelectuales dependen exclusivamente de la razón ${ }^{347}$ y el ingenio -relacionado con el entendimientono es la excepción. Constatar estas relaciones entre las diferentes potencias y hábitos humanos, me permiten contraponer el binomio ingenio-arte con la imaginativa que puede conllevar algo falso si se deja guiar por la "supersticion y credulidad". En otras palabras, el ingenio es una capacidad intelectual humana, pero no es aún la causa eficiente de la poesía como sí ocurre en las siguientes epístolas ${ }^{348}$.

Atribuyo lo anterior a la nula intención que hasta aquí ha mostrado Pinciano para definir el ingenio, puesto que este no se incluye dentro de la clasificación de las potencias animales o racionales del ser humano, sino que solo está relacionado con el entendimiento y con el hábito intelectual del arte. No es pues una capacidad que amerite particular atención por parte del médico humanista, lo cual revela que no es una potencia o facultad independiente, sino que está delimitada por otra: el entendimiento $^{349}$. Advierto, empero, que esta afirmación debe ser circunscrita al contexto de la "Epistola primera", que reflexiona en torno a la felicidad humana y no trata directamente del quehacer poético.

Hasta este momento Pinciano aleja al ingenio de la poesía; sin embargo, justo antes de que concluya la "Epistola primera" se avista un primer momento en que la capacidad humana y el quehacer artístico se acercan. Promete Pinciano, el interlocutor, a su corresponsal Gabriel: "Yo procurare boluerme a ver con los compañeros para tener que os escriuir, y tambien para saber que cosa es esta poetica, quien el ingenio mas feliz que huuo el mundo, honro tanto con ser sequaz della, y en ella escriptor, procurad vuestra salud" (f. 70). Por supuesto, aquí el ingenio funciona como metonimia de 'persona poseedora de tal capacidad' - a la usanza de la época-, pero adquiere una

\footnotetext{
${ }^{346}$ No quiero dejar de señalar la relación que esto tiene con el principio de Quintiliano anteriormente mencionado. El rētor latino y el médico español propugnan por un ingenio que puede ser aprendido con el stŭdüum de ciertas auctoritates, como Avicena. Sin embargo, esto será más adelante negado en la Philosophia.

${ }^{347}$ Los otros tres hábitos son la sabiduría, la ciencia y la prudencia (vid. f. 36).

${ }^{348}$ Esto podría explicar el por qué Fernández-Corugedo determinó que furor e ingenio son términos sinónimos en la "Epistola primera".

${ }^{349} \mathrm{Mi}$ observación es matizada más adelante, pero quisiera rescatar desde ahora cómo esta presentación del ingenio en la Philosophia será reafirmada por otra poética del presente trabajo: el "Libro" de Carrillo y Sotomayor.
} 
acepción particular cuando se descubre que dicho "ingenio mas feliz" es Homero (vid. fols. 69-70); es decir, un poeta cuyo ingenio es "sequaz" de la poética. Sobre este ingenio versado en poesía y la honra que se le debe se trata en la siguiente epístola dialogada.

Con un matiz diferente, el binomio arte-ingenio se vuelve a mencionar en la "Epistola segunda, o prologo de la Philosophia antigua" cuando se discurre a propósito de la cuestión platónica sobre la verdad y la mentira del arte ${ }^{350}$. Los tres interlocutores del diálogo conversan sobre la dignidad de la poesía -polémica recurrente en las poéticas italianas y españolas del siglo XVI. En este contexto, la segunda voz con más autoridad, Vgo, parafrasea los vv. 408-415 del Arte poética de Horacio y afirma que la corona de los poetas es la honra, o bien la fama, que adquieren a través del esfuerzo y el natural ingenio.

La corona, señor compañero es la honra; a la qual muchas vezes sigue la inmortalidad de la fama: y la subida deste monte alto es el trabajo, ayuntado al natural ingenio. Y si quereys saber que tal ha de ser el trabajo, leed a Horacio: el qual dize, que se ha de exercitar con abstinencia de vino y Venus, y con sudor, y frio, y madrugar, y trasnochar [...]. Esto es lo que Horacio dize: mirad vos si tanto trabajo merece bien la corona del laurel con honra, y aun con la immortalidad de la fama. (fols. 78-79)

El fragmento anterior describe la disciplina ideal que el poeta debe seguir, misma que lo dignifica tanto en el ámbito artístico como moral -piénsese en todas las implicaciones que tenía la honra en la época. Con esto, la Philosophia hace eco de la ars horaciana, la cual puede ser aprendida, practicada y perfeccionada. Sin embargo, tales "reglas y preceptos para hacer rectamente las cosas"351 no son suficientes para obtener "la corona del laurel con honra" y la fama. De hecho, para esto el arte deber ser "ayuntado al natural ingenio": capacidad nata del ser humano que preside la creación poética y que por su misma naturaleza no puede ser aprendida o enseñada, de aquí que se le trate por aparte del "trabajo" o bien del ars.

Es evidente que el médico vallisoletano en la "Epistola segunda" cambia las connotaciones del binomio arte-ingenio previamente descritas porque aquí parte de la tópica mayor horaciana. Por lo tanto, el ingenio se distancia del arte - no puede ser enseñado- y se acerca al quehacer del poeta. Opino que el nuevo significado del binomio es resultado precisamente de la fuente en la que Pinciano basa sus reflexiones, más que ser propiamente una contradicción o inconsistencia de la poética. Esto, además, se aúna a la inexistencia de una definición de ingenio. Como consecuencia, no es posible saber hasta qué punto las características de este "natural ingenio" han cambiado con respecto a lo que

\footnotetext{
${ }^{350}$ La respuesta de Gabriel, personaje in absentiā que sintetiza la conversación de los tres interlocutores al final de cada epístola, califica como ingeniosas (vid. f. 98) las consideraciones hechas en la "Epistola" a propósito de esta cuestión. Por lo que explicaré en seguida, este adjetivo puede ser leído como "creativas".

${ }^{351}$ Diccionario de la lengua castellana, en que se explica el verdadero sentido de las voces, su naturaleza y calidad, con las phrases o modos de hablar, los proverbios o refranes, y otras convenientes al uso de la lengua, s. v. arte (disponible en línea: http://web.frl.es/DA.html).
} 
se afirmó en la "Epistola primera". Se desconoce, entonces, si aún se le considera una capacidad dependiente del entendimiento y si continúa siendo incorpórea ${ }^{352}$, pero me parece claro que desde ahora se habla del ingenio propiamente poético.

Por lo anterior, el ingenio en la Philosophia adquiere principalmente su connotación de la auctōrițās o tradición usada para la argūmentātı̆o, aunque los matices que pueda tener, así como su relación con otros términos - como el arte-depende de la interpretación que el humanista haga de dicha auctōrĭtās. Esto se confirma en la "Epistola tercera de la esencia y causas de la Poetica", que explica lo que su título anuncia y confirma la predilección de la ı̌mítātı̌o ecléctica-que sigue Pinciano en su poética- al criticar sutilmente a los ciceroneanos. La imitación de un solo modelo tiende más al servilismo ${ }^{353}$, que se debe principalmente a la falta de "ingenio libre": "no se yo para que fin imitare yo mal, lo que otro escriuio y inuento bien, no lo puedo sufrir, ni aun Horacio sufrirlo pudo, el qual dize destos tales imitadores, que son rebaño sieruo que no tienen ingenio libre para inuentar, y sieruo que estraga lo que otro hizo bien" (f. 103). La cita recupera una vez más la poética horaciana, aunque el humanista -en concordancia con sus propios preceptos- la hace suya y glosa los versos latinos como "ingenio libre". De esta forma enaltece a este último sobre el "in artum" (v. 134) del Arte poética ${ }^{354}$

Me parece que esta mención, al estar sustentada nuevamente por la tradición horaciana, conserva la denotación del ingenio expuesta en la "Epistola segunda"; a saber, es una capacidad nata involucrada con el proceso poético. Sin embargo, se explota su potencialidad creativa y, como consecuencia, se modifica su relación con el arte. Ya no son dos aspectos que trabajen en conjunto para obtener "la corona del laurel con honra", sino que Pinciano se inclina a favor de un ingenio libre del ars, a fin de evitar una ı̈mütātı̆o servil. Por tal motivo, he preferido usar ahora el sintagma “tradición horaciana" en lugar de "poética horaciana", pues se conservan las bases del Arte poética, pero su interpretación no se origina únicamente a partir de sus versos. Es decir, como era común en la época, Pinciano, humanista que privilegia el eclecticismo, lee a Horacio y a sus fuentes en general a través de comentarios y eruditas glosas.

\footnotetext{
${ }^{352}$ Algo similar ocurre con el arte, pese a que se le da una sucinta definición. A este no se le vuelve a llamar hábito intelectual, aunque en su caso mantiene su perfectibilidad -su esencia de "hábito".

${ }^{353}$ Con base en la investigación de Rodríguez Beltrán, la agudeza entró en la discusión entre ciceroneanos y tacitistas. Esta, por evidentes motivos, repercutió también en las connotaciones que se le dieron al ingenio (vid. Las fuentes antiguas de la agudeza del ingenio en la retórica renacentista, pp. 31-34).

${ }^{354}$ Los versos a los cuales hace alusión Pinciano son los 131-135, en los que se habla de la materia poética pública y de su tratamiento: "Publica materies priuati juris erit, si / non circa uilem patulumque moraberis orbem, / nec uerbo uerbum curabis reddere fidus / interpretes nec desilies imitator in artum, / unde pedem proferete pudor uetet auto peris lex" (Quinto Horacio Flaco, Arte poética, Tarsicio Herrera Zapién, trad. y ed.). Horacio considera que el poeta puede volver suya la materia poética aún y cuando la ı̌mŭtātı̌o sea de un solo modelo y se mantenga estrictamente dentro de las normas impuestas por el ars.
} 
A continuación, Alonso López califica nuevamente al ingenio de "natural” -tal y como hizo en la "Epistola segunda"- y lo acerca al furor poético platónico, sin llegar a equipararlo. Aún en la "Epistola tercera", Fadrique determina que el objeto de la poesía es lo verosímil y, siempre con base en las enseñanzas de Horacio, diferencia la materia usada por el poeta de la del orador, con lo cual cifra las cualidades de cada uno de ellos. La voz más autorizada del diálogo afirma: "Torno a la materia de que, y digo vltimamente en doctrina de Horacio, que la Moral Philosophia es el sujeto de la poetica, principalmente de la manera, que principalmente el orador quiere arte y estudio, y el poeta natural ingenio" (f. 115). La distinción entre el poeta y el orador da nueva luz a la relación existente entre el "natural ingenio" - poeta- y el "arte y estudio" -orador. Otra vez el ingenio se distancia pareciera que de forma más determinate- del arte al que se agrega el stŭdı̆um ${ }^{355}$. Los extremos del binomio arte-ingenio se convierten en las características esenciales que definen al orador y al poeta, respectivamente.

Gracias al diálogo que impera en la Philosophia -tanto a nivel formal como de contenido-, la mención anterior se desarrolla en el fragmento 5 de la "Epistola tercera", que trata de el "Efficiente de la poesia" -como reza en el ladillo (vid. loc. cit.). Aquí, por primera vez en la conversación de los tres amigos, nace la incógnita de qué es el ingenio y cuál es su función en la poesía. El tema de este fragmento incita a Vgo a cuestionar los ya conocidos versos horacianos:

El orden mismo de la platica nos ha traido a lo que faltaua, porque auiendo dicho de la forma, fin, y materia poetica, restaua el efficenite que agora acabays de dezirme, que es el natural ingenio, Vgo dixo: Assi es la verdad, que es lo principal; aunque Horacio dize, que el no sabe qual es mas importante a la poetica, la arte y estudio, o la vena natural, y verdaderamente que me haze mucha dificultad esta su sentencia, q[ue] dize assi. El poeta nace, y el orador se haze: la qual parece contaria a la primera, porq[ue] si el poeta nace con el, y le es natural? para que el estudio y la arte? (fols. 115-116)

La relación -mas no sinonimia- del natural ingenio con la vena natural es innegable, así como la identificación de estos como causa eficiente de la poesía y su contraposición con el arte, al punto de cuestionar la necesidad de este. Para conseguir esto, Vgo parafrasea uno de los principios del Arte poética ("aunque Horacio dize, que el no sabe qual es mas importante a la poetica, la arte y estudio, o la vena natural" -vv. 408-409 ${ }^{356}$ ) y lo glosa posiblemente a la luz de su comentador latino: el gramático Acrón ("El poeta nace, y el orador se haze”). Sin embargo, en ningún momento se

\footnotetext{
355 Como he advertido en el "Capítulo II", prefiero emplear el término stŭdĭum para rescatar la connotación que tenía estudio en la época de las poéticas estudiadas.

${ }^{356}$ Antonio García Berrio aclara con erudición que estos pasajes no son tomados directamente de Horacio, sino que se hacen eco de principios ciceronianos, principalmente cuando se distingue al poeta del orador (vid. Formación de la teoría literaria moderna, 2, Teoría poética del Siglo de Oro, pp. 111-112). Esto confirma mi señalamiento a propósito de la recepción de las fuentes clásicas en los Siglos de Oro, de la cual Pinciano es un claro representante.
} 
especifica cuándo se trata de Horacio y cuándo de su comentarista -u otra auctōrĭtās- porque se califica al conjunto como saber horaciano y se le otorga la misma autoridad ${ }^{357}$.

Así pues, Vgo es portavoz de una inquietud que hizo correr mucha tinta: ¿el poeta nace o se hace? En la Philosophia, la respuesta está en la voz de mayor autoridad, Fadrique, quien entrelaza las enseñanzas de Aristóteles - de quien toma el principio de las cuatro causas-y Horacio para ofrecer una solución reconciliadora ${ }^{358}$ :

Fad. se sonrio vn poco, y dixo despues: Està bien, mas se deue aduertir, que la poetica se considera diferentemente, segun sus causas diferentes: el que considera la eficiente dize muy bien, que es el ingenio y natural inuentiuo: y el que considera la materia acerca de que trata, dira, que para ser buen poeta, deue tener mucho estudio: y el que considera a la Poetica, segun ambas causas eficiente y material, dira lo que Horacio, que la vna y la otra: arte y naturaleza son tan importa[n]tes q[ue] no se sabe qual mas lo sea. (f. 116)

En la actitud de Fadrique ("se sonrio vn poco") se adivina la facilidad con la que este -y posiblemente el autor López Pinciano- consideraba la resolución de uno de los problemas que más preocupaba a los humanistas de su época. Esta no es única y depende de la causa que se tome en cuenta - eficiente o material - por lo que la excelencia poética puede deberse a una capacidad nata -ingenio-, al arte o a ambos. De tal manera, la solución, además de ecléctica, evita todo tipo de confrontación directa puesto que no es definitiva y absoluta. Opino, empero, que puede inferirse una inclinación por la última -la cooperación del arte con el ingenio-, debido a que el poema es el resultado de las cuatro

${ }^{357}$ La frase, "El poeta nace, y el orador se haze", a veces reducida simplemente al "poeta nace", fue tan popular que se volvió un refrán. Sin embargo, sus orígenes durante la época, y aún hoy, han sido tema de debate como lo constata Alberto Porqueras Mayo en su comentario de Cervantes y de cuyo estudio recupero a Acrón como posible autor de la máxima o, al menos, de una de sus variantes: "el poeta nace". No obstante, como el mismo hispanista aclara -y como refiero en la nota anterior-, el origen puede provenir de otros autores clásicos: "La frase se atribuye a Platón, Cicerón y otros [...]. Según Ringler (p. 498), Acrón, un gramático latino del siglo II de nuestra era, es el primero en testimoniar, en forma escrita, el famoso dictamen. Y ello ocurre comentando los famosos versos (295-298) de Horacio de Ars Poetica en los que ridiculiza la noción, atribuida a Demócrito, de que se puede escribir versos con sólo talento natural [...]. La segunda emergencia escrita del dictum ocurre en Poliodoro Virgilio, De Rerum Inventoribus (Venecia, 1499, lib. I, cap. VIII) [...]. Después aparece en In Terentium Prenotamenta (Lyon, 1502) de Badius Ascesius [...]. Todas las obras citadas eran muy populares y cuentan con muchas ediciones. Sugiere Ringler una posible influencia de Poliodoro Virgilio en Cervantes. Pero como la frase era muy popular y está muy viva en la tradición autóctona española esta influencia me parece poco probable" (Estudios sobre Cervantes y la Edad de Oro, pp. 52-53, n. 3). En el caso de Pinciano es igualmente difícil identificar de quién toma la cita original, lo que deja en claro que aún está pendiente un trabajo pormenorizado sobre las fuentes pincianas, aunque esto no impide ver parcialmente, como ya indiqué, la forma en la que estas eran leídas.

${ }^{358}$ Fadrique es la voz más autorizada en la poética no solo por poseer las cualidades intelectuales con las que se le ha descrito al inicio de la poética (vid. fols 1-2 y "Capítulo II"), sino porque su función dentro del diálogo es conciliar las diferentes posiciones que tanto Vgo como Pinciano personaje ofrecen. Así pues, es común observar en la Philosophia estas conclusiones abiertas; es decir, postulados casuísticos que aceptan más de una solución posible. Así ocurre, por ejemplo, cuando se determina cuál es la causa final y material de la poesía: "Passo, dixo aqui Fad. no ta[n]tas injurias a los metros, que (aunque yo en mi vida no los hize) soy muy abogado dellos, y deuen tener su lugar en la Poetica. Confiesso, que en alguna manera repugnan a la forma de la Poesia que es la imitacion, pero pugna mucho en fauor del fin della que es deleyte para la enseñança: porque la Poetica desseando deleytar busca el deleyte, no solo en la cosa, mas en la palabra; y no solo en esta, mas en el numero de las silabas cierto y determinado, al qual dizen metro. Assi que por la causa final (que es el deleyte) pierde la formal en cierta manera, q[ue] es la imitacion" (f. 108). 
causas y no solo de algunas de ellas. Además, Fadrique insiste en recordar el consejo del poeta latino, una auctōrĭtās: "dira lo que Horacio, que la vna y la otra".

Ahora bien, así como esta respuesta ofrece tres posibles fallos a tan intrincada pregunta, también concede tres vías para interpretar la relación del binomio arte-ingenio. Si se considera la causa eficiente, el ingenio se coloca por encima del arte; pero si es la causa material la que se observa, entonces el arte está sobre el ingenio. Finalmente, tomar en cuenta ambas causas coloca el binomio en equilibrio. Con esto Pinciano sintetiza en pocas y elocuentes palabras las tres principales posiciones que tomó la teoría poética de la época, mismas con las que el vallisoletano se mantiene en diálogo abierto y que se encuentran presentes en el corpŭs de esta investigación. Se comprende ahora el porqué dentro la Philosophia hay ocasiones en donde ingenio y arte se encuentran en equilibrio y otras en las que se prioriza el ingenio ${ }^{359}$.

En conclusión, el ingenio es la causa eficiente de la poesía; sin embargo, al pensar en las implicaciones que la capacidad tuvo en la "Epistola primera", opino que este es un ingenio particular: el natural inventivo. Se enaltece pues la denotación que el ingenio ha tenido desde la tradición clásica como la capacidad creadora innata del ser humano. Asimismo, al contraponerlo al arte, que compete a la causa material de la poesía, se entiende que este ingenio -natural inventivo- no posee preceptos que lo rijan.

A continuación, Pinciano personaje, con base en la poética de Horacio (vv. 295-301) ${ }^{360}$, critica el tipo de ingenio que propone Demócrito: "Con mucha breuedad se me ha dicho esto del ingenio, y yo desseaua mas dilacion. Porque dixo Democrito, que el tal ingenio auia de ser furioso: y esta sentencia suena mal al oydo, y bien al refran comun que habla de los musicos y poetas" (loc. cit.). En la "Episola primera", Fadrique definió a los refranes como "Euangelios pequeños" (f. 24, vid. “Capítulo II"), pero en este caso la afirmación sobre Demócrito no es más que un "refran comun" ${ }^{361}$. Pinciano, la voz del neófito, desacredita así el uso de este ingenio furioso, en el que me detengo ahora.

He insistido en que el natural ingenio y el furor no son términos intercambiables. Mi lectura se basa en el principio de esta nueva digresión, porque la Philosophia es bastante clara: "tal ingenio auia de ser furioso"; es decir, es un tipo de ingenio, el furioso-llamado anteriormente vena natural. No son por tanto sinónimos, pero el ingenio furioso y el furor sí están estrechamente relacionados.

\footnotetext{
${ }^{359}$ No quiero dejar de mencionar que Pinciano no privilegia en ningún momento el arte y únicamente en estas palabras de Fadrique se ofrece la posibilidad de que este explique la excelencia poética. Sin lugar a duda, la herencia de Huarte había calado con fuerza en el médico vallisoletano.

${ }^{360}$ Dichos versos son precisamente comentados por Acrón. En consecuencia, creo que es probable que la fuente que usa López Pinciano para glosar estos versos es la del gramático latino y no Cicerón, como sugiere García Berrio. Sin embargo, no es posible concluir nada. De hecho, es incluso posible que ambas actoritates y otras estén presentes en esta reflexión del diálogo humanista.

${ }^{361}$ Se refiere a los versos de Horacio (Sat. II, 7, vv. 117): "aut insanit homo, aut versus facit". Al igual que "El poeta nace, y el orador se haze", el verso fue tan común en la época que se convirtió en un tópico y posteriormente en un refrán.
} 
La clave está en el adjetivo que califica a la causa eficiente. De hecho, cuando el tipo de ingenio se refiere al furor se le adjetiva justamente como furioso, porque el ingenio se encuentra bajo la influencia de esta alteración ${ }^{362}$, a la que se dará inmediatamente mayor atención por parte de los otros dos interlocutores.

Se inicia, como dije, una nueva discusión que versará sobre la teoría platónica de los furores, los cuales, explica Vgo, son una perturbación del entendimiento:

Platon en el Phedon, o de Pulchro ${ }^{363}$, dize que furor, es vna alienacion en la qual el entendimie[n]to se aparta de la carrera ordinaria [...]. Porque Platon pone quatro especies de furor diuino, y sobrenatural, y sobre ellos pone el Poetico. Assi que ay furores terrenos, y estos son locuras y desuarios: mas de los diuinos, quien tal dira? Quien imaginara, que el de los Prophetas y Sibilas era furor malo y loco? (fols. 116-117)

La división entre el furor divino y terrenal - "locuras y desuarios"- es consistente con los principios de la poética, ya que los tres integrantes del diálogo confirman a lo largo de su conversación que ellos solo conversan de "tejas a baxo" (f. 6). El médico vallisoletano se preocupa por problematizar aquellos temas que competen a cuestiones terrenales, con lo que previene cualquier censura eclesiástica. Asimismo, afirma su afiliación al conocimiento sensualista, posiblemente a causa de su formación como médico y a la influencia que tiene sobre él Huarte.

De tal forma, Fadrique afirma que se puede hablar de la poesía, pues esta pertenece al mundo de "tejas a baxo" 364 y le da, como Huarte, una explicación natural e incluso fisiológica. Ofrece entonces la definición de ingenio furioso:

${ }^{362}$ Esto lo justifico con la siguiente explicación del ingenio furioso, que recuerda al ingenium excellens cum mania huartiano. Para López Pinciano, tal ingenio es como el que poseía Catón, que "facilmente se arrebata y eleua de las cosas aca materiales, y se sube a la consideración y contemplacion, el qual arrebatamiento y eleuacion puede muy bien aco[n]tecer humanamente, sin ser inuencion de diuino furor particular" (f. 118).

No quiero dejar de señalar que existe otra forma en que el ingenio sale de sí mismo o bien "alza el vuelo" metáfora común en las poéticas de la época. Sin embargo, lo único que se conoce de esta manera es que está relacionado con la necesidad que requieren los conceptos agudos (vid. "Capítulo II"). Por este motivo, no creo que este tipo de ingenio que llega "hasta el cielo" (f. 274) sea el furioso, pero ya que es la única vez que se le menciona, no puedo agregar más a propósito.

${ }^{363}$ Vgo cita con imprecisión a Platón, porque en lugar de identificar este pasaje con el Fedro, lo hace con el "Phedon, o de Pulchro". Se trata, empero, de un lapsus, ya que Pinciano, por el subtítulo "Pulchro", sabía que tal tratamiento de los furores está en el Fedro. Sobre esto, Alex Bermúdez señala lo siguiente: "Esta formulación platónica, sin embargo, aparece en realidad en Phaedrus 243c9-245c5. Ya es incorrectamente citado en la primera edición de la Philosophía Antigua Poética como Phedón; el lapsus en la citación es evidente pues el subtítulo de Pulchro es aplicado por Marsilio Ficino a su traducción del Phaedrus, no del Fedón, en su monumental Omnia Divini Platonis Opera de 1484 que debió de ser la usada por el Pincinao (Phaedrus vel del Pulchro a Marsilio Ficino traductus)" ("Lectura y crítica del Fedro platónico por un crítico aristotélico del siglo XVI: el Pinciano contra los 'divinos furores' (Phaed. 243e9-245c5)", p. 3 ; disponible en línea: https://www.academia.edu/15397294/Lectura_y_crítica_de_El_Pinciano_a_los_furores_divinos_de_Platón_Phaed._243 e9-245c5_?auto=download).

${ }^{364}$ Más adelante, Fadrique hace hincapié en la naturaleza terrenal del ingenio poético: "Todo està muy bien dicho: pero quando los poetas inuocan a las Musas, no piden el furor diuino? Fadrique dixo: Y los Poetas Satiricos de nuestros tiempos, y los Liricos y derretidos amantes, a quien inuocan? Por ventura viene socorro y furor diuino en su ayuda? Y por ventura verna el diuino furor en sus malignos y mueles versos? Mejor sera, que digamos lo dicho. Y digo de nueuo, que el furor Poetico es natural, y ayudado alguna vez del espíritu diuino, como se vee en Dauid, y otros 
Toda mi vida fuy amigo de no yr a mendigar al cielo las causas de las cosas que puedo auer mas acabaxo. Y assi esto destos furores diuinos de Platon, no me satisfaze, porque el dize ser quatro: Prophetico, amoroso, Bachico, y Poetico: del Prophetico yo no hablo, porque en la verdad es diuino; mas en los tres que siguen, yo no se que diuinidad halla Platon [...]. El Poetico se pudiera reducir mas a la diuinidad: pero ni tal quiero confessar: porque si hallamos causas naturales y euidentes, para que auemos de yr a las sobrenaturales? Ingenio furioso es el del poeta, que es dezir vn natural inuentiuo y machinador, causado de alguna destemplança caliente del celebro. Tiene la cabeça del poeta mucho del elemento del fuego, y assi obra acciones inuentiuas y poeticas. (f. 117)

Como ya se observa en la intervención de Vgo, la paráfrasis de Fedro modifica el orden de importancia de los furores divinos, lo que obedece a la finalidad de la poética dialógica. Asimismo, el tercer furor platónico-Fedro, 245a-245b- se interpreta a través de la lente huartiana y explica la posesión de las Musas como una "destemplança caliente del celebro". Fadrique reafirma también las dos cualidades principales de este tipo de ingenio: "natural inuentiuo y machinador". La definición recupera la potencia creativa de la causa eficiente y evidencia, a mi parecer, una imprecisión en la erudita Philosophia. Esta ya se había avisado en la "Epistola primera", pero no se había confirmado.

He dicho que a furor e ingenio furioso los une una relación causa-efecto y tal "causa" es descrita por Vgo como "vna alienacion en la qual el entendimie[n]to se aparta de la carrera ordinaria". Por otra parte, Fadrique ha dejado en claro que el ingenio furioso -el "efecto"- es "causado de alguna destemplança caliente del celebro"; en otras palabras, por el furor, esa alienación. Ahora, lo que este último altera es el entendimiento, que es una potencia intelectual en la "Epistola primera", por lo que no está asociada al cuerpo, de la misma forma que el ingenio - una parte de este- no lo está, ni debería estarlo. De hecho, como anoté más arriba, esta es la razón por la que el ingenio se alejaba del proceso poético, mientras que en la "Epistola segunda" se acercaba y, ante la falta de más información, no me era posible concluir si se seguía considerando al ingenio como una parte del entendimiento o no. Por el contrario, este intercambio entre Vgo y Fadrique demuestran que en efecto la causa eficiente es parte de la potencia intelectual que se ve afectada por el furor. La contradicción consiste entonces en la definición fisiológica que Fadrique da al ingenio furioso, misma que contradice los principios de la "Epistola primera". Es más, a la luz de estos, la existencia misma del ingenio furioso, que obra "acciones inuentiuas y poeticas", es imposible. Las inconsistencias en este desarrollo silogístico se deben, una vez más, a que la connotación del término que analizo depende de la auctōritāa o auctoritates usadas por el médico vallisoletano.

semejantes. Y las mas vezes es ayudado de otro furor natural mas baxo: del qual son tantas las especies, quantos los desseos y apetitos. Del amoroso apetito que añada furor al poético, es tan cierto, que algunos hizieron a Cupido el inuentor de la poetica" (f. 119). Con esto, Pinciano deja en claro que el furor poético puede estar acompañado en menor medida de otros furores como el profético y el amoroso, siempre y cuando no se afecte su cualidad natural. 
El eclecticismo en las fuentes usadas por López Pinciano sigue explotándose, por lo que a estas nociones platónicas agrega la aristotélica (Poética, 1455a31-35). Esta doctrina es superior no solo a la de Platón, sino también a la de Demócrito - en alusión a la crítica de Horacio- y "aun Ciceron" (loc. cit.). De tal guisa, su auctōrĭtās justifica la adición de un nuevo tipo de ingenio: el versátil, con el cual termina la enunciación de los ingenios relacionados con la práctica poética, en tanto causa eficiente. Dice Fadrique: "Mas quien esta materia llegò mas a su perfeccion, como todas las demas, fue el Philosopho en sus Poeticos. El qual dize assi: Es la poetica de varon de ingenio versatil, o furioso" (loc. cit.). El ingenio versátil, contrario al furioso ${ }^{365}$, es “aplicado, y acomodado a todas cosas" (f. 118). Su flexibilidad para asimilar diversas situaciones se debe a que no está alterado por el furor, lo que le permite ser "aplicado". De tal guisa, posee una claridad que le permite "comparar, assemejar, apropriar una cosa con otra, y traherla al propósito de lo que se hace, ù dice"366. El ingenio versátil se caracteriza pues por su capacidad para unir dos palabras o asuntos, pero solo en esta ocasión ya que más adelante solo se enfatiza su "versatilidad”367. Así, no creo oportuno relacionar el ingenio pincianesco con aquel concepto retórico y semántico que une dos términos alejados entre sí.

Con respecto a otras cualidades más estables del ingenio poético, versátil o furioso, se enuncia en este mismo fragmento su varonilidad, o sea, que es propio del género masculino, ya que "la poetica era de ingenio macho y varonil" (loc. cit.). Y la existencia de poetisas no desmiente este principio, debido a que, "assi como ay mujeres en otras acciones varoniles, lo pueden ser en esta" (loc. cit.). Por ende, los ingenios poéticos son principalmente naturales, inventivos, maquinadores y varoniles; y de dos tipos: furiosos oflexibles.

El humanista vallisoletano reafirma y sintetiza las características de estos dos últimos. Además, especifica que son parte de un ingenio: el poético. En breve, hay un tipo general de ingenio natural que se dedica a la creación poética y este se conforma de ingenio versátil que

rescibe facilmente qualquier Idea, o forma de las cosas, o de ingenio furioso: porque el tal es aparejado para la inuencion. Y assi como el que tuuiere arte y natural, sera bueno para la Poetica: el que tuuiere las dos partes del ingenio natural (digo Versatil, y furioso) sera mas pefecto. $(\text { loc. cit. })^{368}$

${ }^{365}$ En concordancia con lo expuesto hasta ahora y con la teoría aristotélica, me parece evidente que la conjunción copulativa disyuntiva "o" excluye entre sí a los dos tipos de ingenio y no ofrece dos nombres posibles para el ingenio versátil.

${ }^{366}$ Diccionario de la lengua castellana..., s. v. aplicar. Para el adjetivo "aplicado", Autoridades envía a la entrada "aplicar": "DA. part. pas. Del verbo aplicar en todas sus acepciones" (id. s. v. aplicado).

${ }^{367}$ Vale la pena agregar que esta versatilidad responde también a una herencia clásica que se observa en la diosa Metis $(\mu \eta \tau \imath \varsigma)$, aspecto revisado ampliamente por Rodríguez Beltrán y Fernández-Corugedo. En esta diosa "se indica ya su adaptabilidad para ajustarse a los problemas concretos que se presentan" (Rodríguez Beltrán, op. cit., p. 66; vid. Fernández-Corugedo, op. cit., pp. 33-43).

368 A partir de esta cita, Fernández-Corugedo cambia su apreciación sobre el ingenio y furor. Opina: “el comentario del Pinciano al 55a 32-34 [de la Poética aristotélica] difiere sensiblemente de los comentarios hechos por los italianos al mismo [...]; para el vallisoletano lo que cuenta es el ingenio; el ingenio es lo inconmovible; el furor un tipo o 
Es notable que un individuo puede no poseer ambos tipos o partes del ingenio natural. Estos, como el "arte y natural", pueden presentarse o no y tener diferente importancia en el poeta, aunque por la médı̌ŏcrĭtās se propugna también por un equilibrio entre ambos ingenios. Sin embargo, a diferencia de la explicación con respecto al arte e ingenio, López Pinciano es claro: la suma de estos dos tipos de ingenio dará la excelencia al poeta.

Aunado a la anterior, el médico vallisoletano advierte sobre el peligro que conlleva un ingenio solo guiado por el furor:

Pareceme a mi que vn poco del furor estraño al natural añadido hara el ingenio lo que vn poco de mareta al nauio que ayudado del templado alboroto camina velocissimamente, y quando es mucho haze que (procurando el piloto contrastar el peligro) se turbe de manera, que algunas vezes no solo no passa adelante, mas buelue al puerto de donde salio: y este es el menor peligro de los que pueden acontecer. (f. 121)

De aquí se colige que el furor debe causar en el ingenio un arrebato moderado para procurar el fin deseado: la creación poética. La Philosophia inaugura en este análisis un principio que será desarrollado de forma particular por cada poética de este corpŭs: los alcances permitidos al furor.

Con esta última reflexión termina la conversación de la "Epistola tercera", a la que me gustaría agregar lo siguiente. Considero que para Pinciano hay dos momentos de la creación poética. El primero de ellos se consigue gracias al ingenio furioso y consiste en el arrebatamiento y elevación del ánimo que contempla así las ideas a poetizar. El segundo momento es guiado por el ingenio versátil, que permite captar la "Idea o forma de las cosas" -el concepto entendido clásicamente ${ }^{369}$ - o bien el verbum mentis de Huarte de San Juan -tal y como observé en el "Capítulo II". Por consiguiente, el ingenio poético está relacionado con el carácter heurístico de la poesía y, retóricamente hablando, con una parte previa a la invenť̌o ${ }^{370}$ : la intellecť̌o, "proceso receptivo-

clase" (op. cit., p. 269). Sin embargo, como ya señalé, esta interpretación es imprecisa, porque no es el furor un tipo o clase de ingenio, sino el ingenio furioso.

${ }^{369}$ Para Rodríguez Beltrán la "noción de concetto es de proveniencia filosófica: al menos en principio, no parece tener ninguna conexión con la tradición de la agudeza. Incluso a pesar de que aquellos teóricos [italianos de la segunda mitad del siglo XVI] ya hablan del concetto desde el punto de vista de la poética o la retórica, parece estar bastante alejado de cualquier elemento que [...] está emparentado con la agudeza" (op. cit., pp. 27-28). Esto lo confirma Antonio Carreira, quien a propósito de los teóricos italianos informa que al "cúmulo de elementos de que echa mano la poesía épica y aún más la lírica los italianos los denominaron concetti, 'conceptos'. El lexema con los sufijos -ismo, -ista ya hemos dicho que es algo moderno: data del siglo XVIII. Ni conceptismo ni conceptista fueron términos usados en el siglo de oro, aunque Gracián forjó el verbo conceptear, pero concepto en sentido retórico sí aparece pronto, alternando con su sentido filosófico de "idea"” (“El conceptismo de Góngora y el de Quevedo", Il Confronto Letterario, 52 (2009), p. 361). Con base en esto y considerando que Pinciano conoció bien a los teóricos italianos, creo que "la Idea" aquí se refiere al 'concepto' entendido desde un aspecto, más que retórico, filosófico.

370 Este lo entiendo como Heinrich Lausberg: "proceso productivo-creador; consiste pues en extraer las posibilidades de desarrollo de las ideas contenidas más o menos ocultamente en la res" (Manual de retórica literaria. Fundamentos de una ciencia de la historia, § 260). 
comprensivo; [que] consiste en comprender las res dadas" ${ }^{\prime 371}$. Se confirma la relación entre ingenio poético y entendimiento, pese a la dependencia fisiológica que presenta el primero.

Sin duda, estas reflexiones son de gran valía y la importancia que se les dedica en la "Epistola tres" lo manifiesta. Por esto es sintomático que don Gabriel, en la "Respuesta”, no agregue o comente nada a propósito del ingenio -la causa eficiente. Por el contrario, sí hace hincapié en el fin útil (causa final) y en la universalidad de la poesía (causa material). Me parece que esto dice mucho sobre el público final de la Philosophia, lo cual la acercaría más a un manual de lectura que de creación. Esto es, Pinciano reconoce la importancia del ingenio en la creación poética, lo explica fisiológicamente y establece una tipología. En ocasiones, lo coloca incluso en un plano superior al arte. Pese a todo, no le dedica más espacio en su poética - como observo ya en la "Respuesta" a esta epístola- y se enfoca más en otras cuestiones de la poética, como la causa final, que ayudan más a entender una poesía que a hacerla.

La conversación de la "Epistola quarta de las diferencias de Poemas" versa sobre las cuatro especies de poesía. El número obedece a la tradición de la que el humanista parte y que considera a la tragedia y a la comedia como dos especies diferentes de poesía. Sin embargo, Pinciano asegura que su interpretación se basa directamente en la Poética de Aristóteles, "que a mi parescer es obra artificiosa, y digna de su ingenio" (f. 127). La obra aristotélica, misma que Pinciano comenta y sigue en varios pasajes de su Philosophia, es digna de consideración e incluso imitación porque es artificiosa y propia del ingenio del filósofo. Me parece que esta afirmación enfatiza el equilibrio que debe existir entre arte e ingenio. Asimismo, es evidente que el ingenio -no solo el poético-puede ser jerarquizado -“digna de su ingenio"- y el de Aristóteles se encuentra entre los de mayor rango.

A partir de esta epístola, las menciones del ingenio que aparezcan en la Philosophia Antigva Poetica retoman y desarrollan en mayor o menor medida la teoría propuesta por Fadrique en la "Epistola tres". En conformidad, cuando se trata en la "Epistola quarta" del metro -característica problemática no solo para el médico vallisoletano, sino para la época-, Fadrique declara que este es creación del ingenio versátil y furioso -nótese que aparecen los dos tipos de ingenio. Esta es razón suficiente para que se le considere como elemento poético y, si bien no esencial, sí importante en la producción artística ${ }^{372}$.

La indiscutible necesidad de ambas partes del ingenio poético -el versátil y el furioso- se reafirma constantemente en el resto de la poética. Concluyo pues que lo expuesto en la "Epistola tres" representa la teoría del ingenio poético elaborada por Alonso López Pinciano. No obstante, en

${ }^{371}$ Loc. cit; también vid. § 139 y § 97.

372 "Ya yo veo (dixo Fadrique) lo que dezis, y que estays toda via muy colerico contra el metro, mas de lo que es razon, que aunque el no tenga esencia en la poetica, y del no se saquen las diferencias legitimas, al fin es obra de ingenio versatil, y furioso qual para la poetica diximos necesario" (f. 147). 
ocasiones en lugar de aparecer el binomio versátil-furioso, aparece inventivo-furioso. Al ingenio inventivo ya se había aludido en las primeras epístolas con el sintagma "natural inventivo" (f. 116), pero no posee una definición como los otros dos tipos. Así, opino solo que inventivo no puede ser sinónimo de ingenio versátil y es, más bien, un tipo que evidencia una de las características del ingenio poético.

Lo anterior se observa en la "Epistola quinta" 373 que trata de la fábula poética. Uno de los temas que preocupan a los interlocutores es la maravilla -'admiración'- que esta debe provocar en su público. Vgo, entonces, comenta las formas para volver maravillosa a la obra y asevera que si el ingenio no es "furioso harto, y inue[n]tiuo" (f. 193), se puede agregar a la fábula elementos admirables, prodigiosos y espantosos, para deleitar a su público. Según Vgo:

la añadidura tambien tiene inuencion en cierta forma, y como ay hombres que sin arrimo andan mal, mas arrimados a arrimo por ligero que sea andan bien: assi ay ingenios que de suyo no son muy inuentivos, mas arrimados a las inuenciones de otros añaden cosas mas que medianas. (Loc. cit.)

El fragmento se inscribe en la esfera de la ı̌mütātı̆o y de cómo incluso para añadir un elemento no originado por el mismo ingenio del poeta existe invención (mas no ingenio inventivo). Pinciano, en la voz de Vgo, ofrece una estrategia a los ingenios que "no son muy inuentivos", ni harto furiosos. Tal hecho, aunado a la observación que hice sobre la intervención de don Gabriel al final de la "Epistola tercera", confirma el destinatario ideal de esta poética: la clase acomodada que aspiraba a confirmar en su persona el ideal del cortesano y para ello dedicaba parte de su ōtüum a la creación poética, posible siempre y cuando tuviese algo de ingenio inventivo. La Philosophia es en consecuencia una poética cortesana ${ }^{374}$.

Ahora bien, Vgo especifica que la añadidura hecha es de "cosas mas que medianas", refiriéndose a la "cosa admirable". Es decir, el artilugio usado por estos poetas sin mucho ingenio inventivo puede provocar admiración más que promedio. Esto acentúa la importancia de la causa eficiente, pues la maravilla en esta época ya gozaba de una gran importancia en las poéticas de la época $^{375}$ y en la Philosophia es "inuencion de ingenio versatil y furioso" (f. 194), al igual que el metro. Parece entonces que cualquier elemento poético será producto de las dos partes del ingenio poético-versátil y furioso-o bien, inventivo.

\footnotetext{
${ }^{373}$ En la "Epistola quarta" existe una mención del ingenio que anteriormente se ha comentado con relación a la agudeza (vid. "Capítulo II").

${ }^{374}$ Además de la posición moderada y ecléctica de Pinciano, esta característica de la poética podría develar un motivo importante para justificar la existencia únicamente de poetas con más arte que ingenio.

${ }^{375}$ Rodríguez Beltrán enfatiza este aspecto al comentar el trabajo doctoral de Javier Patino Loira, puesto que una "de sus ideas centrales es que desde dichos comentarios [a la Poética de Aristóteles] se puede percibir con claridad una creciente importancia de 'lo maravilloso' como ingrediente poético indispensable capaz de generar placer y deleite en la misma medida en que el poeta ostenta su propio ingenio" (op. cit., p. 34). Hay que considerar que lo maravilloso y la admiración -término usado por Pinciano- podían ser equiparables en la época (vid. Diccionario de la lengua castellana..., s. v. maravilloso).
} 
Sin que se defina, la importancia del ingenio inventivo se manifiesta aún más en la "Epistola sexta del Poetico lenguaje". Aquí se reflexiona sobre otro elemento fundamental para la poesía y poéticas españolas: la obscūrütās. Según Pinciano -en la voz de Vgo- existen tres tipos de oscuridad. Las dos primeras son buenas porque nacen del artificio y son de utilidad: una tiene el objetivo de preservar la vida del poeta y la otra es producto de la 'erudición poética' -tan importante para Carrillo y Sotomayor, como analizaré en su momento. Por el contrario, la "tercera escuridad es mala y viciosa, que nunca buen poeta vso; la qual nace por falta de ingenio de inuencion, o de elocucion: digo, porque trae conceptos intrincados y dificiles, o dispone, o (por mejor dezir) confunde los vocablos de manera que no se dexa entender la oracion" (f. 250). Vgo glosa con esto el capítulo 22 de la Poética de Aristóteles ${ }^{376}$.

Como en el caso de la admiración en la fábula, la falta de ingenio inventivo provoca que el poeta eche mano de algunos artilugios -conceptos, específicamente intrincados y difíciles-, pero en este caso es de forma indebida y excesiva. Además, el recurso imitativo para provocar la maravilla obtiene resultados positivos, mientras que aquí los artilugios externos crean una oscuridad viciosa. Por supuesto, tal fragmento podría colocar como contrarios al ingenio y al concepto, pero al no tener clara la inventio de estos últimos (vid. "Capítulo II") no se puede afirmar una relación positiva o negativa. Lo que es innegable es la importancia que para Pinciano tiene el ingenio inventivo y cómo la carencia de este puede provocar que el poeta caiga en error.

Los interlocutores no mencionan nuevamente al ingenio hasta la "Epistola vndecima de heroyca" ${ }^{377}$, en donde se le agrega la cualidad aristocrática. Esto ocurre cuando la épica se compara con la tragedia -glosa del capítulo 26 de la Poética de Aristóteles- y Vgo comenta la necesidad de elementos dramáticos por parte de ambas. La tragedia:

sin estos instrume[n]tos se entiende mal, y con ellos se dexa entender de sabios y necios; y al fin es commo dizen para aluarda y silla: y esto se vee manifiesto, que al leer vna epica no se acomoda al vulgo, sino la gente ingeniosa, y de animo gra[n]de, mas a oyr vna tragedia no ay quien no se aplique (f. 482).

${ }^{376}$ Sandford Shepard ofrece la posibilidad de leer este pasaje bajo la luz de la "nueva poesía (culteranismo), que estaba a punto de inundar toda España, [porque] quizás pueda identificarse la tercera causa de oscuridad con los abusos de este movimiento, y si esta identificación es acertada, entonces, la oposición de Pinciano al culteranismo se basa en la falta de ingenio de éste: es decir, precisamente aquello de lo que más creían tener sus partidarios. Lo más probable es que, en opinión de Pinciano, este movimiento, que no tardaría en tener un teórico en Luis Carrillo y Sotomayor y un maestro en Góngora, se prestase con facilidad a las absurdas aberraciones en que le harían caer los poetas de menos categoría" ( $E l$ Pinciano y las teorías literarias del siglo de oro, p. 64). La interpretación no carece de interés, puesto que pondría a la Philosophia como precursora del debate gongorino. Sin embargo -anoté más arriba (vid. "Capítulo II")- esta reflexión nace principalmente porque Shepard interpreta el concepto agudo como lenguaje florido -tendente a los tropos o demasiado peregrino, usando los términos de Pinciano-, cuando no es exactamente así. Por lo tanto, la explicación del crítico no puede ser sustentada, ya que este pasaje corresponde únicamente a un comentario y reflexión en torno al capítulo 22 de la Poética aristotélica y no a un fenómeno poético que él estuviese criticando, como sí ocurre en la poética de Jáuregui.

${ }^{377}$ Las epístolas en donde no se le menciona son las siguientes: "Epistola septima del metro", "Epistola de la tragedia y sus diferencias", "Epistola nona de la Comedia", "Epistola decima de la especie de la Poetica dicha Dithirambica". 
El ingenio - como la agudeza- no es solo capacidad creadora, sino también receptora. De hecho, gracias a esto, se convierte en un elemento que distingue intelectualmente ${ }^{378}$ dos tipos de hombres: los ingeniosos y de ánimo grande, y el vulgo. La división, pese a no estar totalmente basada en las clases sociales, sí está sugerida, aún más si se piensa en la distinción entre concepto grave y concepto agudo (vid. "Capítulo II"). Además, hay que considerar que se habla de la épica, género aristocrático por excelencia en la Philosophia. Mientras los géneros dramáticos, como la comedia, no son para oídos nobles, como los del embajador de España ${ }^{379}$.

En suma, el ingenio -creativo y receptor- tiene que ser óptimo y más si aspira a elaborar una obra que concrete el ideal horaciano dŏcēre ĕt dēlectāre, al cual Pinciano es fiel. De aquí que en la "Respuesta de don Gabriel" para la "Epistola vndecima" se asegure que solo alguien con "alto ingenio" (f. 464), como Virgilio, puede conseguir tal hazaña poética ${ }^{380}$. La jerarquización de los ingenios -poéticos o no ${ }^{381}$ - está presente en la Philosophia e insinúa una escala de valores que puede ser aplicada a las obras que se produzcan, las cuales pueden ser, por ejemplo, "altas" o "mas que medianas" (f. 193).

Antes de dar por finalizado el exhaustivo diálogo, el médico vallisoletano insiste en el papel preponderante que el ingenio poético tiene para el quehacer poético en la "Epistola doze de las seys especies menores de la Poetica" ${ }^{382}$, donde, además, enfatiza la ūtǐlǐtās de la poesía. Pinciano personaje declara: "la Poetica no mancha sino laua y limpia las manchas, y si yo tuuiera algo de lo versatil y furioso, prouara a inuentar y metrificar como los demas para ser vno dellos" (f. 496). La poética es clara sobre dos aspectos. Primero, es innegable el carácter "limpiador" - ‘catártico'- de la poesía, lo que la vuelve útil para la sociedad ${ }^{383}$. Segundo, el pupilo de la Philosophia, después de los intensos

${ }^{378}$ No quiero dejar de anotar que esta distinción intelectual reafirma la relación que el ingenio tiene con el entendimiento. De tal guisa, pese a la imprecisión que ya señalé, considero que López Pinciano es bastante consecuente con su doctrina.

${ }^{379}$ Las líneas que Alonso Pinciano dedica "Al Conde Ihoanes Kevenhiler de Aichelberg” son elocuentes al respecto, por lo que creo oportuno recordarlas nuevamente: “ Otro si, suplico a V. S. si algun dia hiziere a esta obra digna de sus oydos, los abstenga de la epistola nona, y especialmente del fragmento quarto della, cuya materia es ridicula, y mas co[n]ueniente a orejas populares y cómicas, que no a las patricias y tragicas, quales ser deuen las de los Pirncipes y grandes señores, y quales son las de V.S.[et]c" (s. f.).

${ }^{380} \mathrm{La}$ importancia de la figura de Virgilio en la Philosophia obedece principalmente a la deuda que la poética tiene con una de sus fuentes, los Poetices libri septem de Julio César Escalígero, como tan bien anotó Shepard (vid. "Las huellas de Escalígero en la 'Philosophia antigua poética' de Alonso López Pinciano”, Revista de Filología Española, vol. XLV, n. 1/4 (1962), pp. 311-317; disponible en línea: http://revistadefilologiaespañola.revistas.csic.es).

${ }^{381}$ Pienso en el pasaje en donde se coloca el ingenio de Aristóteles, filósofo, sobre los demás.

382 Esta es la última epístola en donde se menciona al ingenio, puesto que Pinciano no se ocupa de este en la "Epistola treze y vltima de los actores y representantes".

${ }^{383}$ La afirmación es de gran relevancia porque, como señalé constantemente, una de las fuentes principales de López Pinciano es Huarte de San Juan. El interés que este último tuvo por el bien de la República y su preocupación por encauzar todos los ingenios a la profesión que mejor contribuyera al desarrollo social explica indirectamente tanto esta aseveración como la conversación que ocurre en los últimos folios de la poética sobre la República y los amigos (vid. f. 520). Por ello, considero que la Philosophia es también una reivindicación de la poesía a la luz del Examen de ingenios, como si esta se tratase de una glosa que completa el proyecto huartiano. 
coloquios con Fadrique y Vgo, concluye la necesidad imperante de poseer -aunque sea "solo algo"un ingenio versátil y furioso para “inuentar y metrificar". La autoridad que aquí ya tienen las palabras de Pinciano personaje me permite observar el resultado deseado por Alonso López Pinciano en su público. Como la voz del neófito, quien siga las trece epístolas de la Philosophia, ya sea al leerlas o escucharlas, se educa en los elementos esenciales, materiales y eficientes de la poesía, al grado, incluso, de poder aplicarlos en caso de poseer un poco de ingenio versátil y furioso.

Las menciones de ingenio en la Philosophia develan una serie de características que quiero resaltar a continuación. En primer lugar, el ingenio está ligado al entendimiento y, por ello, es una capacidad intelectual y natural del ser humano. Luego, para Pinciano, existen diferentes tipos de ingenio, aunque por la especificidad de su poética se concentra en el ingenio poético, que puede estar conformado por el ingenio versátil y el ingenio furioso. Este último, además, indica que la capacidad natural puede ser afectada por el furor, es decir, una destemplanza del cerebro. Además, lo relevante de este ingenio poético y sus partes es su capacidad inventiva, lo que permite al médico vallisoletano llamarlo la causa eficiente de la poesía. Por este motivo, es indispensable que el individuo posea ingenio poético - preferiblemente versátil y furioso- para la creación poética y de la calidad de este depende también la obra, ya que hay ingenios superiores a otros. Finalmente, no hay que olvidar que se aconseja al poeta acompañar la causa eficiente con el arte y el stŭdŭum para cumplir cabalmente con el dŏcēre èt dēlectāre, la causa final ideal de la poesía.

\section{Luis Alfonso de Carvallo, Cisne de Apolo (1602)}

Alfonso de Carvallo menciona al ingenio en sesenta y cuatro ocasiones en su poética -casi el doble de las de Pinciano. Estas se distribuyen desde los preliminares hasta el final de los cuatro diálogos que comprenden las conversaciones de Lectura, Carvallo personaje y Zoylo entorno al arte poética ${ }^{384}$. Además -al igual que en la Philosophia-, el término se entraña con furor, principalmente por la carga neoplatónica que preside la obra del asturiano, misma que justifica en gran medida la importancia que ingenio tiene dentro el Cisne.

Para iniciar, en la "Dedicatoria a don Henrique Pimentel de Quiñones", Carvallo explica que "este libro Cisne de Apolo, necessariamente se deuia dedicar a quien con tanta luz de ingenio, letras, y virtud, respla[n]deciesse, que pudiesse conuenir el nombre de Apolo” (๔5v). El religioso asturiano llama a su mecenas ${ }^{385}$ Apolo y le otorga así la mayor dignidad poética, puesto que reúne en su persona

\footnotetext{
${ }^{384}$ No debe extrañar este número de apariciones en el Cisne, ya que Carvallo, como miembro de la Compañía de Jesús, refleja la importancia que el ingenio tuvo dentro de los colegios de la orden (vid. Aurora Egido, "La fuerza del ingenio y las lecciones cervantinas", BRAE, t. XCVI, cuaderno CCCXIV (2016), pp. 773).

${ }^{385}$ Sobre el Presidente del Consejo de Aragón (1628-1632), Alberto Porqueras Mayo ofrece en su edición del Cisne de Apolo una breve biografía (vid. Luis Alonso de Carvallo, Cisne de Apolo, A. Porqueras Mayo ed., p. 48, n. 7).
} 
las tres cualidades esenciales del poeta, según el Cisne: ingenio, letras (stŭdium) y virtud. Estas dan luz -'iluminación cognoscitiva'- a su portador y con su resplandor le ayudan a conocer. Entonces, ingenio connota desde el principio una capacidad que revela algo esencial para la creación poética y acerca a la divinidad a quien lo posea, pues Carvallo nombra a Apolo, dios de la inspiración poética y profética.

Considero que de esta forma Carvallo hace eco de la tradición clásica de la cual bebe a través de diferentes polianteas medievales - principalmente la de Badius Ascensius ${ }^{386}$. Por esto prioriza la idea de un tipo de ingenio que encuentra o bien penetra en la realidad, un ingenio agudo (vid. “Capítulo II"), como lo consignan también los diccionarios de la época (vid. "Introducción”). Con todo, me parece que no puede identificarse totalmente con la facultad correlacionadora que explica Joaquín Rodríguez Beltrán en su tesis doctoral ${ }^{387}$. Sin embargo, es evidente que para Carvallo hay un tipo específico de ingenio poseído por los poetas, del que depende cómo estos comprenden la potencial materia poética.

La segunda mención se relaciona con lo anterior y aparece en el paratexto "A los discretos Poetas el Auctor". Como ya he señalado (vid. "Capítulo II"), el jesuita usa la falsa modestia en su

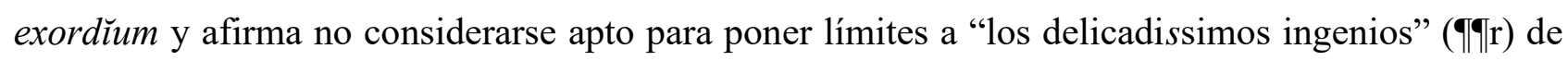
los poetas, a quien se dirige particularmente en este punto ${ }^{388}$. Recuérdese que el ingenio es delicado en cuanto puede penetrar más fácilmente en la realidad, lo cual es imprescindible para el poeta, pues gracias a esto adquiere una dignidad semejante a la del profeta. Y advierto que esto ya se encuentra en la explicación del por qué el cisne es la insignia del poeta, que se encuentra en las primeras líneas del "Dialogo primero de la definicion invencion, y materia dela Poesia, [et]c.":

el blanco Cisne releuado en el gallardo escudo es la insignia de los Poetas, porque con ninguna otra cosa pudieran mejor significar el fin de su arte, y profession que es el deleytar con la suauidad de sus versos a los hombres, y con su dulçura persuadirles la virtud, y afearles los vicios, q[ue] con el Cisne, cuya suauidad y dulçura, suele enagenar los pensamientos de los mortales, de las cosas humildes y baxas, y leuantarlos a virtuosas contemplaciones. (f. 4r)

El fragmento es esencial para la poética porque Carvallo anuncia los principios basilares que rigen su obra. En consecuencia, estos son amplificados con el uso constante de la figură sententiă preferida por el jesuita, la commǒrātǐo, que repite y desarrolla dichos principios a lo largo del Cisne.

${ }^{386}$ Vid. A. Porqueras Mayo, "Introducción” a id., pp. 17-29.

387 Vid. op. cit., p. 34.

388 Vale la pena señalar que la captātřo benevolentiae de Carvallo está principalmente dirigida a los poetas, lo que no significa que estos sean sus únicos destinatarios. De hecho, con su falsa modestia está excluyendo a los poetas ya iniciados como objetivo de su poética, hecha más bien "para satifazer al ignorante vulgo" (đIIr). Sin embargo, Carvallo es consciente de que los poetas pueden ser sus mayores censores, por esto usa abundantemente las fórmulas proemiales $\breve{a} b$ iudicum personā, basadas principalmente en el topos naturum. Así, da al delicadísimo ingenio el primer lugar de las capacidades necesarias para el poeta. 
De tal manera, para Carvallo, el fin de la poesía es "deleytar" a los hombres y con "dulçura persuadirles" a -importantísimo- "la virtud, y afearles los vicios". Asimismo, tal objetivo se consigue a través de la enajenación de los pensamientos -se refiere acaso al entendimiento o razón. Por esto, el poeta se aleja de lo humilde y lo bajo, para elevarse a "virtuosas contemplaciones", mismas que transmitirá a su público. Aquí no se menciona directamente el término ingenio, pero la explicación me parece fundamental para comprender las características y función que tiene en la poética, como se nota en la descripción del poeta ideal.

Lectura, la voz más autorizada del diálogo, afirma: "Poeta aquel se llama propiamente, que dotado de excelente ingenio, y con furor diuino inicitado, diciendo mas altas cosas, que con solo ingenio humano se pueden imaginar, se llega mucho al diuino artificio" (f. 6r). La definición es tomada y asimilada por el asturiano de los Praenotamenta de Badius. De tal forma, el Cisne se vuelve un continuador de las reflexiones medievales sobre poesía en la península ibérica ${ }^{389}$. Tanto Badius como Carvallo entienden que el poeta tiene un ingenio diferente al "ingenio humano", es decir, con el que se nace y es común a todos. El ingenio poético es "excelente" y se ayuda del "furor diuino" para acercarse al "diuino artificio". En consecuencia, se establece una tipología de ingenio y, a su vez, una jerarquización entre el "humano" y el "excelente" que posee el poeta. Este, como concluye Carvallo personaje, posee un "claro ingenio agudo, y excelente" (loc. cit.). En otras palabras, el ingenio poético percibe claramente e 'ilumina' al poeta -como ya mencioné-; es agudo, pues penetra en la realidad (vid. "Capítulo II”); y su excelencia demuestra su superioridad ante el ingenio común, humano.

El carácter receptivo del ingenio -entrevisto en los adjetivos claro y agudo- se desarrolla cuando se relaciona con el entendimiento. Siempre en el "Dialogo primero", apartado §. II, "De la definicion y partes dela poesia", la Lectura recita una cita tomada casi literalmente de Rengifo aunque dice que es de Platón-, con ecos de las observaciones de Badius ${ }^{390}$. La voz autorizada del Cisne define la poesía como "vn habito del entendimiento que rige el Poeta, y le da reglas para componer versos con facilidad". El profesor jesuita toma aquí "poesía” por "arte poética"391, la cual se basa en el hábito del entendimiento - 'constante práctica'- y las reglas que ofrece para “componer versos con facilidad”. A partir de esta definición y la del poeta, nacen dos cuestiones principales: ¿ingenio y entendimiento están relacionados? ¿De quién depende principalmente la creación poética?

389 "Poeta propie is dicitur qui excelenti ingenio proditus divino quod furore concitus et maiora quodque solo humano ingenio excogitari posse videantura elegante carmine conscribens ad divinum artifitium proxime accedit" (Josse Badius Ascensius apud L. Alfonso de Carvallo, op. cit., p. 77, n. 13).

${ }^{390}$ Vid. id., p. 78, n. 14.

${ }^{391}$ Mi lectura se basa en el hipotexto de Carvallo. Las primeras líneas de la poética de Diaz Rengifo rezan: “Arte Poetica es vn habito, o facultad del entendimiento, que endereça y rige al poeta, y le da reglas, y auisos para componer versos con facilidad" (Arte poetica española, f. 1. Disponible en línea: http://bdhrd.bne.es/viewer.vm?id=0000091336\&page=1). 
Y estas se resuelven a qué está refiriéndose específicamente Carvallo: el arte poética y no la creación como tal.

Carvallo personaje cuestiona la definición dada para 'poesía' -'arte poética'- porque esta explica una poética que es solo del ingenio -no del entendimiento. El neófito en la materia afirma: "No me parece señora, que essa definicion es muy propia desta arte, porque essa solo conuendra a los que se aprouechan de su ingenio y natural inclicnacion mas, que de la arte, preceptos y reglas" (f. 6v). La insatisfacción de Carvallo personaje surge porque las palabras de Lectura no involucran al arte en la producción poética. Por tanto, las reglas - presente en la cita de Rengifo- no son por sí solas un arte. Es más, ni siquiera forman parte de este, como indican los sustantivos que usa Carvallo personaje: “arte, preceptos y reglas". La observación de este interlocutor, además, revela una clara oposición entre arte e ingenio que da como resultado dos tipos de poetas, aparentemente irreconciliables entre sí: uno que se guía con arte y otro con su ingenio y natural inclinación -como confirma Lectura más adelante ${ }^{392}$.

Ahora bien, reitero que aquí se trata del ingenio y ya no del entendimiento, aun y cuando se parte de la definición enunciada por Lectura. Pese a que indiqué que la distinción entre ambos se debe a qué se está haciendo referencia, no parece lógico que se pase indistintamente de uno a otro, pues Carvallo personaje critica el arte poética de Lectura. Por ello, creo que para los interlocutores del diálogo el entendimiento sí puede ser interpretado como ingenio. ¿Por qué sucede esto? Referí que la cita reproduce la poética de Rengifo, quien literalmente dice que es el entendimiento la capacidad humana encargada de la poética. Con base en esto, me parece que Carvallo considera la función de la capacidad -la creación poética- y traslada, sin otra explicación, el término usado por su compañero jesuita - entendimiento - al suyo - ingenio. En otras palabras, la actividad que el entendimiento realiza en la poética de Rengifo, la hace el ingenio en el Cisne. Por ende, ocurre un caso similar al que observé en Pinciano, pues el término adquiere sus connotaciones dependiendo de la auctōrĭtās o, en este caso, la misma denotación se aplica a dos términos distintos. Opino además que Carvallo cambia el término porque en parte sí identifica el entendimiento con el ingenio, en tanto que ambos son capacidades receptivas y creadoras, pero no hay duda de cuál es la capacidad humana que privilegia

392 "Es assi que en esta deffinicion solo se comprehenderan los que por su natural, y sin arte quisieron hazer versos de los quales vuo muchos, y aun ay en nuestra España, de donde vino a dezir Democrito, que los Oradores se hazen, y los Poetas nacen y a los tales agora dara esta diffinicio[n], que verdaderamente no es de la arte, sino de natural inclinacion, la qual aunque nos inclina al arte no por esso es arte, ni tan cierta guía como la arte, aunque ayude a la arte, y la arte a la naturaleza" (fols. 6v-7r). En este fragmento, se repite el tópico 'el poeta nace y el orador se hace' -revisado en el apartado de Pinciano-, y es más clara la distinción entre arte y la natural inclinación. Como indicaré más adelante, esta última se relaciona directamente con la vena y el furor, más que con el ingenio, pero la explicación refuerza la separación entre uno y otra, y se perfila la cooperación que entre ambos -arte e ingenio- debe existir para la correcta producción poética, objetivo final del Cisne. 
el jesuita asturiano para la creación poética y cuál la encargada del arte poética como se observa a continuación.

El ingenio adquiere connotaciones a lo largo de las enseñanzas de Lectura y las preguntas de Carvallo personaje. De esta forma, ambos indican que el término analizado requiere de "limitacion, orden, y ornato" (f. 7r), es decir: "Inuencion, Disposicion, y Locucion” (f. 7v). El Cisne es una poética retoricada y Carvallo aplica el ars běnĕ dīcendi al ars poetriae porque la oratoria y la poética:

son ellas tan hermanas, que no es mucho serlo en la diffinicion, au[n]que su diferencia se tienen, porque la limitacion q[ue] tiene, da oratoria, que son los periodos, y clausulas, no se guarda en ella con tanto rigor el numero de pies, ni cantidad de las sillabas, como en la Poesia, cuya falta, ò sobra, tampoco es tan notable en la prosa, como en el verso, en el qual necessariame[n]te ha de auer cierta cantidad y numero de sillabas, so pena de ser conocidos por falsos, aun de aquellos que no saben la arte, por causar notable dissonancia en los oydos, y disgusto en los animos, y assi tiene todo lo que la oratoria puede tener la Poesia, y en lo que toca a la limitacion co[n] mucho mas rigor. (f. $7 \mathrm{v}$ )

Las exigencias del verso - el metro y el ritmo principalmente- hacen que la poesía sea incluso más exigente en sus reglas que aquellas que guían a la oratoria. La comparación entre ambas artes evidencia además que se parte de una pětītı̌o principii: la poesía es un arte. Es entonces una "cierta razon de hazer cosas, aunque del entendimiento procede para enseñarse a otros, y obrar, es menester salga a ponerse en pratica y dar para ello reglas, y preceptos, con q[ue] se ve[n]ga a la forma y fin de la arte" (f. $7 \mathrm{v})$. Lectura confirma que el entendimiento es el encargado del arte poética, pues puede enseñarse gracias a que parten de esta capacidad. Y para esto es imperativo que tal "habito del entendimiento" se ponga en práctica, de lo contrario las reglas aprendidas no se aplican.

El binomio arte-ingenio está perfectamente separado desde el principio y tiene sus propios fines dentro de la creación poética. El arte puede enseñarse y aprenderse, depende del entendimiento y "antes consiste en el hecho, y practica" (loc. cit.). El ingenio por el contrario está relacionado con la "natural inclinación" y por esto no puede aprenderse. En consecuencia, es claro que para Carvallo el arte -y el entendimiento - se compenetra con el ingenio, dándole límites a través de reglas y preceptos que pueden ser efectivamente enseñados, aprendidos y puestos en práctica. Se anticipa un principio primordial para el desarrollo de la imaginativa.

En §. III., "Porque los poetas pueden pintar armas, si son nobles y quantas maneras ay de nobleza”, el ingenio es una vez más claro: "justamente deuia de honrarse a aquel que la naturaleza honro dotandole de claro ingenio" (f. 11v). El ingenio y, más específicamente, el claro ingenio es una facultad natural, misma que merece honra y da nobleza al poeta. Dicha facultad, naturalmente, funciona en dos sentidos: para comprender y para explicar; es decir, descifra -tanto la realidad como las obras creadas con ingenio- y crea. Esto se colige de la siguiente mención. 
En §. IIII., "Las propiedades del Cisne", Carvallo personaje duda lograr comprender cabalmente el significado total del Cisne: "Aunque de mi ingenio no estoy muy confiado de entenderlo, esperando q[ue] el tuyo me lo sabra bien declarar, te suplico nos lo procures dar a entender" (f. 12v). Si bien el ingenio es natural a todos los hombres, no significa que en todos se manifieste de la misma manera y, por ello, algunos pueden comprender o explicar mejor la realidad o los conceptos - rēs. De aquí la importancia del adjetivo que califica al sustantivo, pues este particulariza un tipo de ingenio que propicia la invención poética. De lo contrario, se trata del ingenio humano, como el que posee Carvallo personaje.

Del ingenio propiamente poético se trata en el siguiente apartado del "Dialogo primero", como su título advierte: "Porque los Poetas tomaron aue por insigna. El ingenio y complexion que han de tener, y la primera parte de la Poesia, que es la Inuencion" (fols. 13v-14r). El ingenio tiene una “complexion" específica en el poeta y está relacionado con la inventı̌o, como lo significa precisamente la alegoría del cisne. Según Lectura: "Dixe, que el Cisne era aue, porq[ue] este es su ser, co[n] el qual se declara el del Poeta. Porque sie[m]pre por las aues, por sus alas y buelo, fue significado y entendido el alto ingenio y contemplacion subida" (f. 14r). El vuelo como metáfora del alto ingenio -lugar común en las poéticas de la época- se relaciona con la capacidad casi profética que poseen los poetas, pues se eleva sobre el ingenio humano. Va más allá del común para producir -en la inventio poética"sotiles y delicadas imaginaciones" (loc. cit.), producto de "altos y profundos pensamientos" (loc. cit. $)^{393}$.

Anteriormente, he explicado que la sutileza y lo delicado están relacionados con la agudeza, en la poética dialógica (vid. "Capítulo II”). Carvallo se muestra de tal guisa heredero de una tradición presente también en Huarte de San Juan. Por tanto, estas "sotiles y delicadas imaginaciones" son también agudas, lo que significa que el ingenio las creo, pues este, en sí mismo, es sutil, delicado y agudo. Mi hipótesis se refuerza posteriormente cuando se glosa una de las explicaciones de los Emblemas morales de Sebastián de Covarrubias, que trata sobre los sacerdotes de azor. Dichos traían un ala en sus bonetes, que significaba la "sutileza de sus ingenios" (f. 14v), misma que por contigüidad produce imágenes sutiles ${ }^{394}$. Asimismo, en el siglo XVI, Juan Luis Vives hace una equivalencia similar con la agudeza como cualidad: "la oración es aguda sólo cuando sus palabras o su

${ }^{393}$ La metáfora es tomada de Horacio (Carmina, II, 20), recuperada también por Sánchez de las Brozas (vid. L. Alfonso de Carvallo, op. cit., p. 94, n. 36). Víctor Fernández-Corugedo también asocia esta definición con la de Dante, quien llama al ingenio "alta fantasía" (op. cit., p. 182 y 274). Hay que agregar que esto tiene una raigambre retórica importante. Siguiendo a Heinrich Lausberg, el orador, para persuadir (causa final), debe considerar una serie de imágenes con las cuales se sugestiona de cierta forma para que durante la actio pueda transmitir a su público "afectos fuertes". Tales "representaciones que el orador suscita en sí mismo para estimular el propio pathos llevan el nombre de $\phi \alpha \nu \tau \alpha \sigma i ́ \alpha$ ”, como las llama Quintiliano (op. cit., § 257c).

394 No está de más recordar que la sutileza (agudeza) es una cualidad indispensable para el ingenio y el entendimiento no solo de los poetas, sino también de los profetas. Esta produce obras, pensamientos, reflexiones, imágenes, entre otros, con la misma cualidad. 
significación penetran en lo más profundo de la cosa tratada y esto con una cierta semejanza del ingenio humano, razón por la cual denominamos también agudo al ingenio" "395. Confirmo que Carvallo sigue de cerca una tradición humanística encabezada por el Brocense, Badius, Vives y Huarte, entre otros.

La sutileza, sin embargo, no es el único calificativo que se le da al ingenio, así como tampoco el cisne es la única ave que se asocia al poeta. De tal forma, Lectura comenta la constante comparación entre San Juan el Evangelista y el águila. Este es un motivo suficiente para que "el dicho comun del vulgo, que para loar de buen ingenio alguna persona, suelen dezir es vna aue, es vna Aguila, vuela con su ingenio, y aun parece que con esta frasi quiso el Psalmista significar el infinito entendimiento de Dios diciendo. Qui volat super pennas ve[n]torum" (loc. cit.). Un buen ingenio -no está restringido a la figura del poeta- es un águila porque tiene "ligeréza, velocidád, prontitúd, viveza y perspicácia de algúna persóna" ${ }^{396}$. Todas estas cualidades deben ser consideradas también como parte del ingenio ideal carvallesco y son las mismas que permiten el "vuelo intelectual". Por otra parte, quiero evidenciar cómo nuevamente el entendimiento -"el infinito entendimiento"- y el ingenio -"buen ingenio"- son facultades que trabajan en conjunto durante la inventǐo -seguimos en el "Dialogo primero"- y están intrínsecamente relacionados entre sí, sin llegar a confundirse.

A este conjunto de adjetivos englobados en la imagen del "águila" se agrega que la insignia del cisne da "a entender el grande y delicado ingenio que para este arte es menester" y "el que no tuuiere este delicado ingenio, no podra preciarse de tan ho[n]rosa insignia como es el Cisne" (f. 15r). El ingenio del poeta es entonces también grande y delicado -sinónimo de sutileza y agudeza. De esta forma, se eleva sobre el ingenio común porque "si las alas del ingenio, al entendimiento comun de los hombres no sobrepuja y excede, imposible es ser Poeta. Porque de su diffinicion consta que ha de hazer cosas que sobrepujen otro, no mas que humano entendimiento" (loc. cit.). El ingenio y el entendimiento poéticos deben exceder el natural y demostrarlo en la obra que creen. La equivalencia entre el tipo de ingenio y sus resultados se confirma; por tanto, un ingenio sutil, delicado y agudo, origina obras sutiles, delicadas y agudas.

Por otro lado, el ingenio poético ideal para Carvallo se complementa -como ya anticipé- con el carácter divino, que lo relaciona con el ingenio profético. Esto lo confirma la cita de uno de los Sermones de Horacio, que Carvallo toma de los Praenotamenta de Ascensius ${ }^{397}$ :

\section{Al $q[u e]$ su entendimiento, ingenio, y le $[n] g u a$}

${ }^{395}$ Apud Emilio Hidalgo-Serna, “Origen y causas de la 'agudeza': necesaria revisión del 'conceptismo' español”, en Sebastián Neumeister (ed.), Actas del IX Congreso de la Asociación Internacional de Hispanistas, I, p. 479. Un desarrollo más pormenizado de la agudeza en Luis Vives se puede encontrar en el trabajo de Joaquín Rodríguez Beltrán, op. cit., pp. 233-261.

396 Diccionario de la lengua castellana..., s. v. águila. La referencia la hace también Porqueras Mayo (vid. L. Alfonso de Carvallo, op. cit., p. 95, n. 38).

${ }^{397}$ Vid. L. Alfonso de Carvallo, op. cit., p. 96, n. 42. 
mas diuina tuuiere que otro hombre,

le daras el honor de aqueste nombre. (f. 15v)

Entendimiento, ingenio y lengua -su inventı̆o y èlŏcūtı̆o- son superiores a los de los seres humanos comunes porque se acercan a la divinidad, como supuse a partir de las consideraciones de Carvallo sobre agudeza (vid. "Capítulo II"). Tal divinidad tiene que ser nata, puesto que es una predisposición del ingenio y entendimiento, como su lengua demuestra.

Aúno a lo anterior los resultados de Víctor Fernández-Corugedo, quien, al analizar etimológicamente la terminología griega con la cual se relaciona el ingenio, encontró que este "tiene

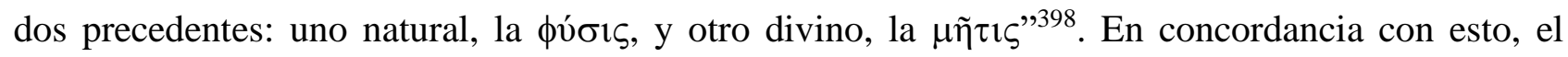
discurso de Carvallo es un fino tejido entre el pensamiento filosófico -en tanto recupera la divinidad de la causa eficiente de la poesía-, el ingenio y la retórica latina. Esta última es además esencial para concretar el objetivo del profesor jesuita: contruir un arte poética basada en los principios retóricos. Observo luego que tal relación podría ser un precedente importante para la creación de un arte de ingenio. Dicho de otra forma, el Cisne prescribe las cualidades necesarias del poeta ideal, a las que da preceptos, reglas y hábitos a seguir, aceptando y respetando sus cualidades divinas.

Siguiendo de cerca la teoría huartiana del ingenio, Lectura afirma que "no todo ingenio es aplicado a vna ciencia, o facultad, y no ay ingenio que sea apto para todas sciencias; sino que assi como las facultades y professiones tiene[n] sus differe[n]cias entre si, ni mas ni menos ay diferencias en el ingenio de los hombres, que vnos son habiles para vna profession, y otros para otra" (fols. 15v16r). Efectivamente, el ingenio nato determina de manera importante si un individuo pude dedicarse o no a la poesía:

es menester gran inmaginativa [sic], y esta es la diferencia de ingenio que a esta facultad pertenece, y lo mesmo a todas las artes que consisten en proporcion, figura, y armonia, como son, el escriuir, eloquencia, astrologia, medicina, gouernacio[n], matematica, pintura, y milicia. En las quales no puede auentajarse el que no tuviere sutil imaginativa. La qual tiene su differencia con el entendimiento, y son cosas distintas y diferentes, de donde viene que puede vno tener bonissimo entendimiento, como dixe, y no ser Poeta por faltarle la imaginatiua, como le puede faltar, por ser diferente cosa que el entendimiento, como todo es doctrina de don Iuan Huarte. (f. 16v)

Este fragmento, en parte reproducción del Examen de Huarte de San Juan ${ }^{399}$, aclara y enfatiza un aspecto que hasta el momento no era completamente claro, pues los interlocutores intercalan los términos constantemente en las definiciones: ingenio y entendimiento son dos facultades diferentes. A partir de esto, quiero especificar dos aspectos: la excelencia del primero no implica la excelencia del segundo; luego, del ingenio depende directamente la poesía -lo que se enfatiza en dos ocasiones

\footnotetext{
398 Op. cit., p. 24.

${ }^{399}$ Vid. Examen de ingenios, pp. 395-396.
} 
más. Asimismo, la imaginativa, rasgo distintivo del ingenio, es la encargada de la separación entre ingenio y entendimiento; y su presencia cualitativa influye en la disposición poética de cada individuo $^{400}$, como expliqué en el "Capítulo II". Ya he comentado que en el Cisne hay una tradición rastreable desde la época clásica ${ }^{401}$ hasta Huarte de San Juan, misma que en este caso rige las siguientes consideraciones fisiológicas de Carvallo, basadas en el calor, topos en tratados y poéticas (vid. "Introducción").

Lectura enuncia tres grados de calor: el de los poetas, los enamorados y los coléricos. De estos, el calor poético debe ser seco, porque es el que conviene a la imaginativa ${ }^{402}$-cualidad distintiva del ingenio - fundamental para el poeta y "los que no la tuuieren, no pueden ser Poetas" (f. 17v). La razón de tal afirmación se explica con las funciones que tiene este componente del ingenio: la búsqueda o creación de la materia poética (la invenť̌o) y su disposición (dispǒsĭť̆o):

La materia del Poeta es tratar de cosas verdaderas, ó fingidas, las quales ha de hallar y buscar la inuencion primera parte de la poesia, y esto con la imaginatiua, y no solo inuentarlas, pero el disponerlas en la forma conueniente, y ordenarlas en la forma conueniente, y ordenarlas a su fin, es todo obra de la ymaginatiua y de diferente officio, que tiene el entendimiento, y assi el que le faltare ymaginatiua, le falta potencia para obrar en esta arte elegantemente, aunque sepa preceptos, como lo hizo Tulio. (fols. 17v-18r)

En conclusión, la imaginativa es la potencia que permite al poeta crear, puesto que los preceptos, reglas y stŭdŭum -en suma, el arte- no son suficientes. Además, esto vale no solo para el primer momento de la invención poética - como se podría pensar, al seguir la tradición platónica-, sino también para la dispǒš̆ť̆o, en donde podría suponerse una mayor participación de los preceptos, aunque no es claro.

${ }^{400}$ Me parece pertinente remarcar que la imaginativa es el rasgo distintivo del ingenio, lo que no los vuelve términos intercambiables, como supone Aurora Egido, aunque este último sí posee una relación con la experiencia mística -como mencioné: "Carvallo en el Cisne de Apolo [...] no sólo identifica la 'ymaginativa', es decir, el ingenio, con la capacidad de invención, sino que se extiende sobre la vena poética y la inflamación casi divina del poeta, equiparando su experiencia a la del proceso místico" (vid. "La hidra bocal. Sobre la palabra poética en el Barroco", Edad de Oro, VI, 1987, p. 85).

Siguiendo este principio, la imaginación tampoco es un producto del ingenio como asegura Antonio García Berrio (vid. Introducción a la poética clasicista. (Comentario a las Tablas Poéticas de Cascales), p. 175).

${ }^{401}$ Para Fernández-Corugedo, la imaginación, facultad ya rastreable en el pensamiento de Jenofonte, Platón y Aristóteles, es anterior a la razón y determina el carácter no racional (mas no irracional) del lenguaje poético basado justamente en la relación armónica de elementos diferentes entre sí. Con base en esto, se explicaría una forma alternativa de comprender y explicar la realidad, cercana a la divinidad (vid. op. cit., pp. 14-25 passim).

402 "Si y qua[n]do mas seco fuere el calor sera mejor Poeta, y de aqui se colige, que en el verano se compone mejor que en hibierno, por ser tiempo caliente y seco" (f. 16v). Para Carvallo, el calor que necesita el poeta es una cualidad más que lo acerca a la figura de Apolo -la divinidad-, no solo a causa del "planeta" que este rige -el sol-, sino también porque desde lo alto "influye el calor a las criaturas inferiores" (loc. cit.). La preeminencia poética se presenta una y otra vez como apología del arte divino ante el vulgo ignorante -como elocuentemente representa la alegoría performativa interpretada por Lectura y Zoylo. Subrayo lo dicho por el desarrollo que este discurso tiene en la poética intelectualmente elitista de Carrillo y Sotomayor. 
Por otra parte, durante la descripción de la inventǐo, la imaginativa es tanto un rasgo distintivo del ingenio -que la separa del entendimiento ${ }^{403}$-, como un tipo del mismo: ingenio sutil y delicado (vid. f. 18r) ${ }^{404}$. Tal tipo, sin importar que tan relacionado esté con el calor y, por lo tanto, cercano, a lo que se entiende por furor poético, siempre debe ser claro (vid. loc. cit.), es decir, comprensible. He notado el cuidado que tiene Carvallo sobre este aspecto, al punto de que, sin haberlo mencionado en este párrafo, no deja de hacer hincapié a propósito en la octava didáctica ("Por aue el claro ingenio es denotado", f. 18r), junto al hecho de que el "ingenio aventajado" (f. 18v) es aquel que alcanza una gran imaginativa.

Es imperativo que el poeta reconozca esta capacidad en sí mismo para elegir el tipo de materia poética que puede tratar, como aconsejaba Horacio en su Arte poética (vv. 38-41). Asevera Lectura: "La qual materia dize Oracio ha de tomar cada vno conforme sintiere sus fuerças y talentos acomodandose con su ingenio y ciencia" (f. 18v-19r). En concordancia con lo expuesto, el poeta tiene un tipo específico de ingenio - sutil y delicado ${ }^{405}$, al cual debe reconocerle sus particularidades, porque dependiendo del grado y tipo de imaginativa que tenga, puede escoger el género y el tipo de composición para los que es apto.

En las líneas que reproduzco también se afirma que el poeta debe acomodar su obra a la ciencia que conozca, no en tanto preceptos (arte), sino en cuanto al saber que posee. Es decir, debe tomar en cuenta el conocimiento que tenga sobre la materia que desea tratar, ya que la poesía trata “cosas verdaderas" o "fingidas" (f. 17r), pero verosímiles o "semejantes a verdad, sin que se cue[n]te en ellas cosas imposibles, que repugnen al entendimiento, y orden, ordinario de successos, ni a la naturaleza" (f. 20v). Es evidente que en esta definición el entendimiento tiene una misión imprescindible, porque es el encargado de determinar si lo que se poetiza es conforme a la naturaleza y a la realidad.

El entendimiento funge pues como limitante del ingenio poético, porque si "el fingir fuesse sin su limitacion y con cierto, no puedo negar que seria mentir, mas quando es conforme a cierta orden, y limitacion, no es mentir, antes es loable officio del Poeta" (fols. 20r-v) ${ }^{406}$. Como he mencionado, Carvallo hace constantemente énfasis en los límites que deben de ponerse a la poesía,

${ }^{403}$ Sobre esto, Carvallo menciona más adelante que existen diferentes sentidos de interpretación -basado en la exegesis medieval que ya Dante recuperaba en su carta al Cangrande della Scala- y precisamente la distinción entre imaginativa y entendimiento es más clara, puesto que con la primera se interpreta un significado que no es posible hacerlo con el segundo (vid. f. 29r). A propósito, se puede revisar también a Fernández-Corugedo, op. cit., p. 276.

${ }^{404}$ Es posible que por estas líneas Aurora Egido haya asumido que para Carvallo la imaginativa es lo mismo que ingenio. Sin embargo, en varias ocasiones, se insiste en que es una característica que permite la distinción entre ingenio y entendimiento, por lo que no me parece conveniente identificar ambos términos.

${ }^{405}$ Esta idea se repite en el f. $21 \mathrm{v}$.

${ }^{406}$ La verdad poética es un tema que interesa bastante a Carvallo. Por eso agrega más adelante: "La fiction del Poeta es significacion de cosa falsa por verdadera, ni co[n] animo de engañar, antes significa cosa muy cierta" (f. 22v). El ingenio, en conjunto con el entendimiento, dan como resultado ficciones verdaderas. 
por lo que, en este fragmento, puedo inferir que están implicados ingenio y entendimiento. Por tal motivo, estoy de acuerdo con la conclusión de Fernández-Corugedo con respecto al entendimiento como limitante de la parte imaginativa del ingenio ${ }^{407}$.

Como he sugerido anteriormente, el ingenio de Carvallo es divino. El Cisne pone en relación casi desde el principio al poeta con el profeta, pero esto se desarrolla con mayor profundidad a partir del §. IX., en donde se "Prosigue la mesma materia, y tratase del principio que tuuieron las fictiones". Aquí Lectura afirma: "Que en hablar obscurame[n]te los Poetas, imitan a los sanctos Prophetas, y ansi en su diffinicion se dixo, que imitaua[n] al diuino artificio, de todo lo qual consta el raro ingenio, que para fabricar estos artificios y machinas, es menester declarado por el Cisne en ser aue, como diximos antes" (f. 34r). Los poetas y los profetas son similares porque su raro ingenio -el mismo que se eleva sobre los ingenios comunes- los acerca al "diuino artificio" y les hace "hablar obscurame[n]te". Este aspecto divino y místico de la poesía es necesario porque la oscuridad de la que habla Carvallo aumenta la dificultad y con esta "el apetito de saber" (f. 34v). En otras palabras, tiene una función didáctica. El Cisne sigue el principio horaciano dŏcēre ět dēlectāre para afirmar que la poesía enseña por medio del deleite, auxiliada con los ornatos de la êlǒcutť̆o.

Por lo anterior:

los Poetas el ver la rudeza de los hombres, y sus votos ingenios, que lo eran tanto, que no hallaron palabras co[n] que les dar a entender, y enseñar las cosas altas, subtiles y delicadas, especialme[n]te las espirituales, y ansi vsaron de figuras, semejanças, y comparaciones que $s \mathrm{e}$ veyan, para que destas cosas visibles, viniessen al conocimieto de las inuisibles, de lo qual ta[m]bien vsò Christo nuestro bien, conociendo nuestra rudeza, para nos enseñar cosas tan remontadas de nuestros rateros entendimientos, como son los mysterios y verdades catholicas de nuestra sancta Fê. (f. 36r)

Las "cosas altas, subtiles y delicadas" pertenecen a un saber profundo e incluso divino como "los misterios y verdades catholicas". Su complejidad es tal que solo pueden ser comprendidos por el ingenio rudo - contrario al agudo ingenio - a través de comparaciones que asocian imágenes conocidas con las nuevas y místicas. El ingenio sutil y delicado crea de esta forma artificios que ayudan a penetrar en verdades ocultas a simple vista.

Carvallo rescata la divinidad poética de la antigüedad clásica, pero la cristianiza y vuelve incluso a Cristo una especie de poeta. Su elogio a la dificultad ${ }^{408}$ de esta $o b s c \bar{u} r \grave{r} t \bar{s}$ divina se justifica

407 "El entendimiento, sin embargo, tiene su papel en esto de la poesía, cual es limitar los excesos de la imaginación para no caer en la mentira" (op. cit., p. 275). Y más adelante agrega que el "entendimiento ya había dicho antes que limitaba los excesos de la imaginación, por ello en este sentido literal el entendimiento tiene el principal papel a despecho de la imaginación, a la que limita" (id., p. 277).

408 "El elogio que Carvallo hace de la dificultad y del misterio parte, en definitiva, del concepto sagrado de la poesía y de la oscuridad implícita en los misterios divinos. Oscuridad bien adornada para que mejor se acepte y recuerde, pero oculta siempre a los detractores. Y lo que es más interesante y que subyace en la mayor parte de estos teorizadores, oscuridad que viene a ser la clave diferenciadora entre orador y poeta. [...] La defensa de la oscuridad tenía su base en el concepto divino de la poesía. Que los misterios ocultos fueran sólo discernibles por unos pocos es asunto que ayuda a 
primero porque es didáctica y luego porque acerca los ingenios rudos a las cosas sutiles y delicadas, a las que, de lo contrario, solo se accedería con un ingenio que comparte estas mismas cualidades. Por tal motivo, la inflamación divina debe ser guiada por la claridad del entendimiento, pues la oscuridad que se elogia podría volverse en algún momento incomprensible ${ }^{409}$. Y con esto quiero recordar que incluso el ingenio para Carvallo es claro.

Como ya el título de la poética lo anuncia, el ave que define todas las cualidades y excelencias poéticas enunciadas es el cisne, porque su insignia declara el ingenio del poeta (vid. f. 42r). De hecho, el cisne se encuentra cercano a Apolo, pero el dios pagano es también cristianizado por Carvallo, por lo que asocia por contigüidad a Jesucristo con el cisne, ambos limpios e inmaculados (vid. f. 50r). Y esta última observación debe aplicarse también al ingenio del poeta, precisamente porque el cisne representa metafóricamente dicho ingenio, dotándolo de una divinidad casi profética.

Pese a la importancia casi divina que posee el ingenio poético, no se debe pensar que solo en este recaiga el provecho de las composiciones poéticas. Dos formulaciones diferentes pueden ofrecer la misma utilidad al receptor, pero no por esto ambas tendrán "tanta gracia, ni ingenio" (f. 112r), pues no se crean o disponen de la misma forma. Así lo aclara Lectura a Carvallo personaje en el "Dialogo Segundo de la disposicio[n] y forma de la poesia Castellana, que son versos, y coplas, con que se

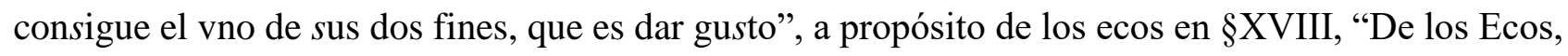
y Laberynthios, y de las letras acrosticas".

Los ecos son composiciones breves y de gran complejidad, razón que vuelve imprescindible al ingenio. No obstante, de realizarlo sin dicha capacidad primordial, puede seguir cumpliendo su función práctica, aunque el resultado no será ni ingenioso ni gracioso -es decir, armonioso ${ }^{410}$ - y no provocará el dēlectāre prescrito en la poética. Observo entonces que el ingenio está en este caso

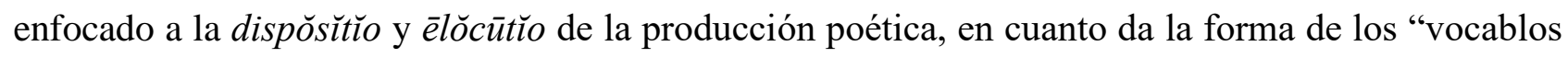
pues se hazen versos y composturas, que porque imitan en ellos repitiendo los reflexos al eco natural les llaman ecos" (loc. cit.). Por lo tanto, más que la rēs, se busca la verba y la agraciada disposición de esta.

De la misma forma, el ingenio está presente en el laberinto, que es ingenioso y lindo cuando "se haze de versos de arte mayor" (f. 114r). Me parece notable que estas dos construcciones métricas

\footnotetext{
plantear desde una perspectiva diferente el hermetismo de la poesía gongorina, sin excluir las razones retóricas y de otro tipo con las que se ha venido argumentando al respecto" (A. Egido, "La hidra bocal", pp. 85-86). Siguiendo esta reflexión, Carvallo está ya definiendo y justificando una obscuridad no tanto erudita, sino, más bien, de origen divino.

${ }^{409}$ A propósito, dice Egido: "Se podía buscar en lo verdadero y en lo fingido para la invención, pero haciendo que la dificultad del poeta en el hallazgo pasase a ser, en el texto, dificultad discernible por el entendimiento. El ingenio pertenecía a la invención y en ese territorio casi todo estaba permitido si se plasmaba en ordenada disposición y con las elocuciones pertinentes" (id., p. 102). A la verdad se puede acceder por medio del ingenio, pero debe estar bien guiado por el entendimiento, de lo contrario se corre el riesgo de caer en la mentira.

${ }^{410}$ La gracia aparece en diversos momentos en el Cisne y es uno de los resabios renacentistas que están presentes en la poética, ya que recuerda los ideales estéticos del siglo XV.
} 
son ingeniosas -únicas menciones del término en el "Dialogo segundo"-, porque el ingenio está especificando algo y no está siendo caracterizado con ningún adjetivo-agudo, sutil, delicado o claro. Es pues un adjetivo para dos tipos de composiciones poéticas. Así, es probable que aquí no se esté hablando de un ingenio específico como en los casos anteriores, sino de la facultad en sí, necesaria para tales creaciones, posiblemente por su complejidad. Sin más ejemplos a propósito, empero, me parece evidente que cualquier conclusión es parcial.

Ahora bien, considero pertinente señalar que Carvallo vuelve a esta facultad visible y mesurable, al usarla como adjetivo de los ecos y laberintos. Dicho de otra forma, se nota el ingenio en el uso o ausencia de ciertos elementos formales poéticos. Asimismo ocurre en el "Dialogo Tercero, de la disposicion y forma de la Poesia, con que se alcança el segundo fin, que es aprouechar" en el apartado §.IIII, "De las tres partes principales de la comedia, que son Prothesis, Epitasis, y Catastrophe, y de la loa, o introito". Este último es un tipo de exordĭum cómico cuyo objetivo principal es la captātĭo benevolentiae. Para su creación, el poeta escoge alguno de los cuatro tipos de exordia o decide no agregar ninguno a su comedia. Con ello, se pone a la vista el ingenio, "porque han dado los Poetas en alabar alguna cosa como el silencio, vn numero, lo negro, lo peq[ue]ño y otras cosas en que se quieren señalar y mostrar sus ingenios, aunque todo deue yr ordenado al fin que dixe, que es captar la beneuolencia y atencion del auditorio" (f. 126r). Este ingenio, nuevamente sin adjetivar, es aplicado a la dispǒsĭť̆o al escoger el material que se agrega o no y su orden.

Considero que en tal visibilidad de la capacidad creadora se nota cómo el receptor percibe el ingenio del poeta, porque, en efecto, de este depende la captāť̌o benevolentiae. En consecuencia, Carvallo señala una capacidad del ingenio: su importancia en la creación poética para establecer un lazo entre el ingenio del emisor y el ingenio del receptor y crear una comprensión entre individuos ${ }^{411}$. Esto mismo, aunado a la posibilidad de materializar el ingenio a través de la poesía, provoca que los mismos receptores sean testigos y jueces del ingenio de los poetas, porque sus versos no son solo visibles, sino también perdurables en el tiempo.

De lo anterior se colige la importancia del ingenio para que los héroes históricos sean eternizados por los poetas y alcancen la fama: "Y assi juzgauan los Romanos que mayor premio se deuia a los Poetas que con la agudeza de sus ingenios celebraua[n] los hechos de sus capitanes, que

${ }^{411}$ Sobre este punto regresa más adelante Carvallo en §.IX., "Disposicion, partes, y circunstancias de la historia". Aquí trata la superioridad de la Eneida, donde se transloca el orden cronológico de los hechos, y, aun así, se consigue "causar a los que la oyesen mas desseo de saberla, y porque no pareciesse preuertir los tiempos la cuenta en persona de Eneas, y el fingir a Venus pedir misericordia a Iupiter para su hijo, por causar esperança de verle libre lo hizo, al fin con la buena traça y disposicion ingeniosa se causan todos aquellos afectos". El ingenio -nuevamente como adjetivodetermina la forma de la disposición de los eventos y el cómo se presentan (sea por quien lo cuenta o por los fingimientos). Como resultado, provoca la expectativa deseada en el espectador, similar a lo que ocurre con la creación de la captätĭo benevolentiae en los exordia de la comedia. 
a los mesmos que co[n] el trabajo de sus personas los executauan" (fols. 135v-136r) ${ }^{412}$. Como observé más arriba (vid. "Capítulo II"), el trabajo de la agudeza del ingenio -se note el adjetivo- es más valioso que los trabajos del soldado o héroe cuyo valor y hazañas militares son llevados a la fama. Carvallo apela sin duda por una utilidad poética de carácter moral. Esto lo interpreto porque las obras provechosas son aquellas eternizadas y puestas al servicio de un extenso público tanto cercano como lejano en el tiempo. Así, la poesía, con la agudeza del ingenio poético mediante, aporta enseñanzas a la República ${ }^{413}$; se muestra el dǒcēre de la poesía.

Por otro lado, la capacidad que tiene el ingenio para ocultar conceptos con figuras -la obscūrĭtās que comparten las obras poéticas con las revelaciones de los profetas- vuelve más artificiosas a las sátiras. El ingenio les da el valor cómico y en este, como en los versos, se muestra justamente esta capacidad. Sobre los apodos explica entonces Lectura:

Si son como no sean con animo de ofender, ni de dar pesadumbre, ni maliciosas, que llaman purezas, sino solo con intento de entretenerse, mostrar ingenio, y dar gusto. Y para esto es menester mucha gracia natural, porque no se han de dezir las cosas al descubierto, como dezir soys tuerto, o corcobado, sino con cierta cubierta, como tratando de motejar se dize en vn librillo de entretenimiento, que vn motejador para llamar a otro corcobado le dixo, temprano aueys cargado, y el otro le respondio, y bien temprano pues no aveys abierto mas de vna ventana, motejandole de tuerto. (f. 144v)

La comicidad de la sátira implica no decir las cosas llanamente, sino velarlas y esto con gracia natural. Esta es una cualidad que podría asociar al ingenio, aunque la falta de desarrollo no me permite asegurarlo. Por el contrario, me parece evidente la razón por la que este velo es equivalente a "mostrar ingenio", puesto que da la comicidad a través de los "dichos satyricos, procurando dar a entender el concepto" (loc. cit.). La obscūrĭtās debe ser entonces parcial, suficiente para provocar la risa, pero no al punto de volver incomprensible el concepto.

Me gustaría mencionar que en esta comicidad se privilegia también la función lúdica de la poesía - el dēlectāre-, pues los motes se componen con intención de "entretener". Lo anterior no implica que este género menor tenga que ser siempre moral o moralizante; de hecho, existen "Satyras perjudiciales, y maliciosas, estas tambien si van al descubierto arguye a poco ingenio del que las dize" (f. $145 r)^{414}$. El ingenio, luego, no engendra únicamente una sátira moral. Más bien, ayuda a que se

${ }^{412}$ El pasaje parte del texto ciceroniano Pro Archia poeta, cuya tradición revisa brevemente Porqueras Mayo (vid. L. Alfonso de Carvallo, op. cit., p. 278, n. 52).

413 “Zoylo. Que mayor premio le auia de dar a quien derramauan tinta, que a los que vertian propria sangre. Lect. No respeto de sus trabajos se premiauan sino del prouecho que dellos redundaua a la republica y assi eran premiados los Poetas, mas que los capitanes, porque estos solamente dauan exemplo a los que se hallauan presente con sus hechos, y espantauan a los enemigos con quien peleauan, y aquellos a los ausentes, presentes, y futuros, ponian delante el exemplo, y a los ausentes ponian espanto" (f. 136r).

${ }^{414}$ Sobre la posibilidad de que el ingenio pueda ser usado para fines negativos, se dice en el "Dialogo quarto" que los poetas pueden banalizar los temas religiosos y entonces se puede apreciar que estos, "preciandose de Christianos emplean su ingenio en servicio del enemigo" (f. 189r). El mal empleo del ingenio pone en entredicho la nobleza del poeta, 
consiga la causa final de la composición poética, la risa, ya sea que esta sea de utilidad para la República o de mero entretenimiento. Tanto la inventǐo -búsqueda de la rēs-como a la dispǒsĭtĭo búsqueda de verba y el orden-son los pasos que procuran esta causa. Aquí, la obscūrĭtās también juega un importante papel, debido a que aumenta el interés del espectador y mueve el ingenio de este para que se interese más en el mensaje de la poesía. Todo gracias al ingenio que recubre los conceptos cómicos, morales o no.

La obscūritāas que provoca el ingenio está también expuesta y es visible en los enigmas, una "de las cosas en que se muestran su ingenio los poetas entre otras muchas" (f. 152v). Carvallo se suma a la tradición más antigua que asocia el ingenio a las composiciones breves -mecanismo con el que se logra la obscūrĭtăs ${ }^{415}$. No obstante, lo que le interesa destacar al jesuita asturiano sobre el enigma son dos aspectos. Primero, se trata de "vna sentencia por vna semejança de cosas encubiertas" (loc. cit.); y, segundo, que "debaxo de semejanças y comparaciones, y con vocablos alegoricos equivocos o encubiertos dezimos y significamos alguna cosa procurando, que con dificultad se entienda" (fols. 152v-153r). La dificultad que se obtiene implica un reto para el ingenio de los receptores y "quando la vengan a entender vean todos que le couino todo lo que della se dixo" (f. 153r). Concluyo que develar la utilidad del concepto oculto aporta una gran satisfacción memorable, porque, como mencioné en el apartado de agudeza (vid. “Capítulo II”), la obscūrĭtās y la brěvĭtāspropia del enigma- son para Carvallo didácticas.

El paradójico juego de mostrar el ingenio a través de composiciones poéticas que velan parte del significado se repite con el epigrama (vid. fols. 154r-155v) y luego con las epístolas (vid. fols. 159v-159r). Sin embargo, entre estos géneros, el único que necesita de un ingenio agudo es el epigrama -tal vez por el tipo y grado de artificiosidad-mas no en la sátira o en la epístola, donde el ingenio se muestra con la dispǒsĭtĭo. De hecho, en el exordĭum de la comedia, donde tampoco se adjetiva el ingenio, también este se muestra a través de la dispǒsĭť̆o. No puedo afirmar, empero, que de esta dependa la presencia de un ingenio no adjetivado, porque también en el epigrama, que requiere un ingenio agudo, se trata de una cuestión de la dispǒsĭť̆o -qué decir y qué no. Por tanto, puedo deducir que es el tipo de creación poética el que requerirá o no la agudeza del ingenio.

Con base en lo anterior, mencioné que para Carvallo hay géneros agudos (vid. "Capítulo II”), pero todos requieren del ingenio y algunos, si no necesitan de agudeza, sí piden otras actividades o capacidades como el trabajo y la memoria. Así ocurre con el "cento" que es "vna compostura que se haze de versos, y medios versos, tomados de differentes partes y diuersos propositos, traydos y

que desde el primer diálogo queda establecida como cualidad que debería perseguir el oficio, al eternizar solo virtudes y acentuar lo pernicioso de los vicios, en consecuencia, de su dǒcēre.

415 Vid. J. Rodríguez Beltrán, op. cit., pp, 105-116. 
acomodados a otra compostura y materia, sin q[ue] el Poeta ponga ningun verso suyo" (f. 191v). Para esto es necesaria:

mucha gracia, y de no poco ingenia [sic] y trabajo, y que requiere gran memoria, ha de venir estos versos muy cosidos al proposito, y tanto que parezcan auerse hecho para aquella materia y no para otra, dos versos ò mas juntos tomados de vna parte, no es licito, que no se suffre tomar de vn lugar mas de vn verso, ò parte del. (loc. cit.)

La gracia, así como en la sátira o en los símiles, es necesaria y debe aunarse al ingenio, a la diligencia y a la memoria para crear algo que simule ser una obra nueva ${ }^{416}$. El objetivo de este es contrario a lo que se pretende con el símil, que busca más bien la semejanza con lo que se intenta imitar, como el retrato con el retratado. Sin embargo, en ambos se debe de mantener tanto la gracia como el tipo de ingenio. Supongo que este tampoco es agudo porque se parte de versos ya hechos y el gran trabajo que requiere no implica un arte como tal. Es una creación nueva, o mejor, pretende y debe parecer ser así, pero que no deja de tomar algo ya ingeniado.

La poesía ingeniosa es producto "de la vena, y furor poetico" (f. 162v), a los cuales hay que poner límites. Este es el propósito del último diálogo del Cisne: "Dialogo Quarto, de el decoro que sedene [sic] guardar en la poesia de la vena, y furor poetico". Aquí, al explicar la creación de las figuras retóricas, se dice que los símiles:

son comparar y asemejar vna cosa con otra, hazense breues, como dezir, son las mujeres espejo. Y otras ay mas largas que consisten en descripcion, porque se descriue la comparcion y lo co[m]parodo [sic], muy en particular haze esta figura muy graue la compostura, arguye a ingenio y con ellas se declaran y entienden otras cosas, que sin ellas no podrian darse a entender ni entenderse. (f. 183v)

En el fragmento, ingenio denota uno de sus significados más comunes: encontrar relaciones entre dos elementos que, preferiblemente, no sean opuestos o lejanos entre sí. Lo último es contrario a lo estipulado por la estética barroca acerca del concepto. Evidentemente aquí se trata de una figura retórica, el símil, aunque no deja de ser notable la potencialidad que se le da al ingenio como capacidad que correlaciona.

Para Carvallo, hay un límite bien específico con respecto a los símiles que "han de ser muy semejantes a lo que se comparan que en esto esta su gracia, como la del retrato en parecer al retratado" (loc. cit.). Nuevamente se ponen limitantes al quehacer del ingenio, en este caso relacionado a la inventǐo. Esta, señala Lausberg, consiste en encontrar "una feliz casualidad; efectivamente, la inventio es en realidad una palestra de la natura (especialmente del ingenium [...])"417. La correspondencia entre ingenio e inventio se refuerza y enfatiza a partir de las elaboraciones ingeniosas, por las que se

\footnotetext{
${ }^{416}$ Este hecho es bastante significativo si se toma en cuenta que el Barroco es la época en donde tratados como el de Torquato Accetto ven la luz. El arte de la disimulación y el ingenio que este requiere ya estaba perfilado en poéticas retoricadas como el Cisne.

417 Op. cit., $\$ 260$.
} 
puede acceder a un conocimiento que de otra forma "no podrian darse a entender ni entenderse". En el símil, entonces, está presente el ingenio más esencial, es decir, aquel que comparten todos los seres humanos. Por esta razón me parece que no hay una adjetivación, porque tal figura sirve más bien para acercar el conocimiento a los que carecen de la agudeza necesaria para ver más allá (vid. "Capítulo II").

Retomando ahora el título del último diálogo -"Dialogo Quarto, de el decoro que sedene [sic] guardar en la poesia de la vena, y furor poetico"- cabe preguntarse si ingenio, vena y furor poético son sinónimos o no. En principio, al estar los dos últimos separados por la conjunción copulativa, podría suponer que estos no son intercambiables. Aunque se debe tener presente que la conjunción no siempre significa dos términos diferentes, sino sinónimos. A esto hay que aunar que en §.IX., "De la vena y natural inclinación, que ha de tener el Poeta, y si vale mas que la arte", Carvallo señala que vena y arte no son iguales, con la posibilidadde que la primera sea superior a la segunda. Asimismo, hay otro elemento que es la natural inclinación, misma que en principio parece representar otra cualidad del poeta y que ya se había mencionado en el "Dialogo primero", cuando se define la poesía -'arte poética'- y al poeta.

Sobre la vena y natural inclinación, se afirma con base en la teoría del soplo de céfiro inspirador de Poliziano -presente en el "Dialogo Primero", $\S .4^{418}$.

Lect. Por el soplo del Zephyro, sin el qual no muestra el Cisne la suauidad de su garganta significa vn afflato y espiritu, y como diuino furor y vna alentada gracia, y natural inclinacion, que Dios y la naturaleza dan al Poeta, como se dan otras gracias gratis datas. Sin lo qual no podra hazer ninguna poesia, ni la armonia de sus ca[n]tos recrearà nuestros animos. Carua . Es acaso lo que llaman vena? Lect. Si es y de tanta importancia para el Poeta, que sin ella tengo por imposible poder serlo; aunque tenga excelente ingenio y estudie todo al arte, que con lo vno y con lo otro, no pudo Ciceron cantar los hechos de su republica en verso. (fols. 190r-191v)

La natural inclinación es la vena, pero no es el excelente ingenio. De hecho, la primera es una "gracia gratis" en tanto no todos los seres humanos la poseen, a diferencia del ingenio, el cual, ni siendo excelente, asegura la creación poética, como tampoco lo hace el stŭdĭum del arte. La vena es pues un don divino y natural exclusivo del poeta, por lo que se repite la sentencia atribuida aquí a Sócrates: "Los Poetas nacen, y los Oradores se hazen" (loc. cit.).

He observado a lo largo del Cisne una serie de cualidades que se requieren para la creación poética. No obstante, me parece que la vena es propia y característica del poeta, incluso más que el ingenio -don natural-, por lo que me parece fundamental su descripción. En el Cisne, la vena está relacionada con el divino furor que inflama al poeta, pero solo en ocasiones. De aquí que otra

${ }^{418}$ El soplo del céfiro se encuentra en el libro 7 de la Epistula ad Laurentium de medicis de Angelo Poliziano; sin embargo, como ocurre comúnmente, Carvallo lo toma de una fuente indirecta, en este caso de los Commentarii in Andrea Alciati Emblemata del Brocense (vid. L. Alfonso de Carvallo, op. cit., p. 351, n. 87). 
característica de esta sea su inconstancia; es decir, a diferencia del ingenio, no es siempre efectiva. Es una "alentada gracia" que permite la "iluminación" del poeta en un momento casi de frenesí. Por esto, Lectura dice: "Y el Poeta restriua en la propria naturaleza, y obra con las fuerças de su entendimiento, y ser inflamado con vn quasi diuino espiritu" (f. 194v). La vena, la natural inclinación, es una capacidad que permite al poeta dejarse llevar por este "diuino espiritu". En consecuencia, el arte es inferior a la vena y no tiene cabida en su dominio totalmente natural y prácticamente divino.

La perfección poética, sin embargo, es un conjunto de capacidades y actividades; es un todo. De tal guisa, la vena es esencial para que el poeta se llene de divino furor, el ingenio para encontrar la $r \bar{e}$ de la obra poética ${ }^{419}$-como ya expuse-, y si a esto se le agrega el arte, se consigue una obra superior.

Ansi el ingenio, que està cultiuado con la doctrina, auiendo rocio natural, produze cosas altas y perfectas, y con este proprio rocio produzira las amapolas, y cardos de mil hierros no auiendo sido co[n] la doctrina sembrada, y quando se aya de venir alcançar algo con solo la naturaleça es muy corta la vida de vn hombre para ello, y en vna ora enseña mas el arte que la naturaleça, y vso pueden enseñar en toda la vida, que todo es deprender errando por do[n]de llamo Ciceron a la arte mas cierta guia que la naturaleça. (f. 195r)

La obra artística en general necesita de este ingenio cultivado con arte para crear obras que sean superiores a la naturaleza y así alcanzar su función doctrinal. Carvallo reitera la utilidad y función social de la poesía, y aúna al dŏcēre el dēlectāre, producto de la vena, o bien "furor afflato" (f. 196v), sinonimia que se afirma a continuación.

En $\S X$, “Si la vena de los Poetas es locura, como dize el vulgo, y del Poetico furor", Zoylo asevera: "Fvror y afflato casi diuino me parece, llamastes a la vena y natural inclinacio[n] de los Poetas, cosa que tan recibida esta por locura" (f. 196v.). Lectura responde entonces al vulgo, representado en las palabras de este personaje poco instruido: "La autoridad que Platon, y Democrito, alegaste haze en fauor, y del ingenio y espiritu, casi diuino, q[ue] tienen los Poetas que tu llamas locura, y de entender mal lo que quisieron dezir, vienen los ignorantes a tener a los Poetas en opinion de locos" (f. 197r). La voz autorizada se basa en las auctoritates de Platón y Demócrito, que ya Zoylo había usado para justificar la supuesta locura del poeta ${ }^{420}$.

Según Carvallo, en la voz de Lectura, la doctrina de ambos filósofos griegos debe interpretarse de la siguiente forma: el poeta permite que el furor lo eleve por encima del "ordinario juyzio" (loc.

${ }^{419}$ Lectura corrobora la importancia del ingenio, pues "solo dispone la eredad de nuestro ingenio, para ser capaz de la semilla, de donde, procede el fructo de las obras" (f. 195v). Con semilla se refiere al concepto o bien la rēs, origen de la obra poética.

420 "Zoylo. No es pues tan del vulgo esta opinion que de locos tienen los Poetas. Que no la ayan tenido el Phylosopho Platon, y Democrito, los quales en estas palabras lo declaran. Frustra poeticas fores pulsat qui compos est sui, que en bano (como si dixeran) procura ser Poeta el que sabe de si" (f. 197r). La fuente de estas citas son siempre los Praenotamenta de Badius (vid. L. Alfonso de Carvallo, op. cit., p. 357, n. 104). 
cit.). Por este motivo, consigue "otro mas noble sutil, y delicado pensamiento, eleuandose y embelesandose en el, de tal suerte, q[ue] pueda dezir, q[ue] esta fuera de si, y no sabe de si" (f. 197v). Expliqué en el apartado de agudeza que el furor eleva tanto al sutil y delicado ingenio -superior al del ser humano común-, como al juicio y entendimiento del poeta. Se descarta entonces la posible lectura de la conjunción copulativa como “o”. Con esta descripción, el furor se relaciona con la vena pero no se vuelven término intercambiables.

En suma, por un lado, vena y furor son semejantes -no sinónimos-, y, por otro, estos términos se distancian de ingenio, tal y como Lectura confirma más adelante:

Del embelesamiento y transportacion de ingenio que te dixe, que le llama[n] insanire porque a los ignorantes parece que estan locos. [...] Pues el Poeta quando està ansi transportado, los affectos de su entendimiento tienen mas luz y claridad, por no estar ofuscados con las cosas corporales. Luego no serà insania, ni locura la tra[n]sportacion del Poeta, mas dize, y en el proprio lugar, que la insipiencia es insania y locura. El Poeta no ha de ser insipiente luego, ni loco insano. Y si locura es contra el ingenio, y con el entendimiento incompatible, y el de los Poetas es tanto y tan subtil como bastamente prouamos quando de sus ingenios tratamos. Como puede ser loco el Poeta? (fols. 197r-198v)

La vena y el furor son responsables de que el entendimiento, juicio, pensamientos e ingenio del poeta se eleven por encima de lo normal. Dotan al poeta de su carácter divino que lo coloca al nivel del $\operatorname{profeta}^{421}$.

Con base en esto, me parece pertinente señalar que el poeta, al inicio del Cisne y del presente análisis, se acerca a lo divino gracias a su ingenio; sin embargo, en el "Dialogo Quarto", se especifica que la natural inclinación o vena es la gracia divina que dota al poeta de esta característica. Por supuesto, un hecho no contradice al otro. Insistí en su momento cuando el ingenio es adjetivado o no y en esta cita no lo está. El ingenio por sí mismo es una capacidad nata que permite encontrar relaciones entre conceptos similares o crear una obra poética a partir de otra -centones- o algunos géneros menores -epístola. Sin embargo, el ingenio agudo, sutil y delicado es una capacidad que ya se elevó con ayuda del furor poético, similar al furor profético. Reafirmo pues que este último es un tipo de ingenio propio del poeta divino; es decir, un ingenio ya elevado con ayuda de la vena-furor. La presencia o ausencia de tales adjetivos es por tanto fundamental.

Con esto se complementa la explicación sobre el excelente ingenio, puesto que ni este ni el arte por sí mismos son suficientes para la creación poética, sino que es la vena el tercer elemento necesario sine qua non el poeta no está completo. Ahora bien, pese a que furor y vena son bastante similares, considero que mientras la vena o natural inclinación es una cualidad inherente del poeta,

${ }^{421}$ Más adelante, como ya lo hizo anteriormente, aclara que existen dos tipos de furores. Siguiendo a Platón, uno profético y el otro poético, cuya diferencia es que solo "los amigos de Dios" (f. 201r) poseen el primero y los gentiles el segundo. Esto no anula el carácter divino que de cualquier forma tiene el furor poético, puesto que, como ya se ha dicho, es también un regalo de Dios (vid.f. 190v). 
el furor es algo externo que la estimula. La vena es una intermediaria entre el furor y las demás capacidades intelectivas del poeta que se "embelesan" ${ }^{22}$. Además, como ya señalé en numerosas ocasiones, para Carvallo, el arte -aspecto también externo al poeta, en tanto se adquiere con el

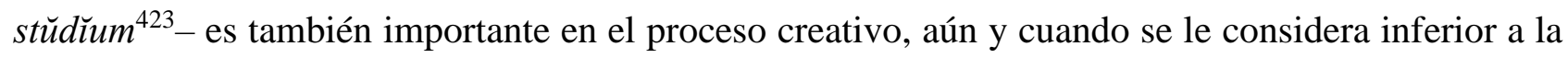
vena.

Contrario a la natural inclinación, el arte-los preceptos, reglas, stŭdŭum-implican raciocinio, mismo que conserva el poeta, pese a que se encuentre "transportado" por obra del furor y la vena a niveles superiores e incorpóreos (divinos, en breve). El furor, además, no entorpece el entendimiento del poeta, sino que le ayuda a ver con mayor claridad. Carvallo sigue de tal guisa la tradición neoplatónica, no solo en cuanto a la teoría de los furores, sino a la suposición de un mundo de las ideas, al cual se llega desprendiéndose del mundo sensible. El arte no es lo único que aleja a la poesía de la locura ${ }^{424}$. El mismo ingenio, como se insiste más adelante ${ }^{425}$, es una capacidad que aun si está exaltada por el furor genera obras con límites y una dispǒš̆ť̆o ordenada. Me parece esencial esto para comprender la importancia que tiene el ingenio durante este paso de la producción poética. Los límites, no obstante, provienen del arte y la doctrina, así que este ingenio no debe ser visto de forma aislada, sino acompañado de su contraparte, el arte, con el cual se guía.

En el diálogo del Cisne se continúa desarrollando la teoría de los furores platónicos - mediados por Badius Ascenscius ${ }^{426}$. Cuando se detiene específicamente en el furor amoroso, Lectura informa que gracias a la "sutil imaginatiua" (f. 203r) el poeta conoce la belleza y la hermosura humana y divina antes de amarlas. Además:

despues quanto mayor conocimiento tuuo dela hermosura por ser de agudo y delicado ingenio $\mathrm{ta}[\mathrm{n}]$ to la viene a amar mas, en vehemente manera y con mayor eficacia, porque [...] los Poetas al principio inflamados co[n] este amor y espiritu, procedido del mucho conocimiento de la hermosura de alguna mujer, la vienen a amar con entrañable amor, durante el qual hazen esas obras tan llenas de vanos amores, mas todo con tanta sutileza, que en ellas muestran bien sus ingenios. (f. 203r)

422 "Ciceron dize, que con vn diuino espiritu el Poeta es inflamado, y en el segundo libro de su Oratoria, q[ue] ninguno podia ser buen Poeta sin el diuino espiritu. Este aun que por faltar este furor no pudo ser poeta, no por esso los llama locos, antes sie[n]te muy al contrario" (f. 200r). Leo divino espíritu como una suerte de divino furor; es decir, como un ente externo que se "posesiona" del poeta.

${ }^{423}$ En este sentido, se podría decir que, mientras el ingenio y la vena son capacidades que están dentro del poeta, el arte y el furor son "fuerzas" externas que dan a uno la ciencia (la poética) y a otra una divinidad que extiende al resto de las capacidades.

${ }^{424}$ La posible locura del poeta también se niega porque el furor poético está relacionado con el furor profético. Por ello, si se afirma que el poeta está loco al ser presa del furor poético, se estaría sugiriendo que el profeta también lo está, al ser poseído por el furor profético. Las profecías de la Biblia, en consecuencia, serían consideradas locuras o ficciones, hecho que se niega (vid. 201v).

${ }^{425}$ Vid. f. 199r.

${ }^{426}$ Vid. L. Alfonso de Carvallo, op. cit., p. 364, n. 118. 
Primero que nada, rescato que el poeta no solo puede ser afectado por el furor poético. En segundo lugar, cuando el furor amoroso inflama el ánimo poético, este muestra su ingenio, aunque no hay provecho (dŏcēre) en la obra como tal, porque la materia poética trata de "vanos amores". De cualquier manera, el ingenio sigue siendo agudo y delicado. Por lo mismo, hay una mayor penetración sobre el asunto: la belleza de la amada ${ }^{427}$.

Asimismo, pese a la banalidad con la que se caracteriza el amor terrenal en el Cisne, en ocasiones el ingenio y el entendimiento superiores del poeta le permiten distinguir entre lo que debe transmitir y lo que no, "dexando lo malo y mejorando lo bueno que es el amor y la belleza" y "atribuyendolo a quien es deuido, que es el criador" (f. 203v). Anteriormente comenté que esto es gracias a la agudeza que posee el ingenio (vid. "Capítulo II") y ahora he esclarecido que la causa de esta es la divinización que vena y furor ejerce en el poeta. En pocas palabras, la agudeza de ingenio es resultado de la vena y furor. De tal manera, la divinización y cristianización del amor humano es posible con la ayuda de las capacidades poéticas. No obstante, solo ocurre cuando el furor, sin importar el tipo, se manifiesta: "la viene a amar con entrañable amor, durante el qual hazen esas obras" (f. 203r).

El párrafo §.XII, "Del segundo furor, y religion de los Poetas”, explica que el furor divino está encargado de "escudriñar algun mysterio diuino y religioso" y "co[n] solo este furor viniesse a dezir de Dios, lo que no alcançara otro que tan sutil ingenio no tuuiera, que mas pudiera dezir vn Gentil de Dios que esto?" (f. 205r). Como diferencia esencial con el poético, el furor profético no necesita la ayuda de ninguna capacidad, como el sutil ingenio. Luego es autosuficiente y no necesita arte alguno, porque la divinidad de su portador es absoluta al ser favorecido de Dios, mientras que el poeta solo se acerca a tal divinidad.

Carvallo agrega que los "Prophetas fueron Poetas, y muchos Poetas fueron Prophetas" (f. 206r). Es posible entonces que los poetas sean partícipes del furor profético, aún al ser poseedores del resto de sus capacidades, como el entendimiento, ingenio, juicio, etc. No obstante, en el Cisne no se deja en claro si tanto el profeta como el poeta son presas de ambos furores a la vez o en momentos diferentes. Tampoco se señala si el profeta, al volverse poeta, utiliza sus preceptos (límites) o si el

${ }^{427}$ El asturiano analiza con más atención este proceso de aprehensión de la belleza y del conocimiento en general, que recuerda lo ya dicho sobre la necesidad de un calor seco para el correcto desarrollo del ingenio poético. Porque "inflamado el Poeta con tanto calor viene a tener muy fuerte imaginatiua, la qual por serlo tanto recibe en si las especies de la cosa hermosa con grande aprehension y conocimiento de donde procede llamarla con gran vehemencia, y au[n]que este amor del Poeta lo signfica nuestro Cisne en su calor, tambie[n] lo significa por pintalla, tirando el carro de Venus, diosa de los amores" (f. 204v). Se descubre la relación entre el furor poético y amoroso, que reside en el calor que distingue a ambos para alcanzar su máxima expresión. Además, es la única ocasión en la que el cisne se asocia a su elemento erótico: Venus, el cual es callado por Carvallo por su componente inmoral y, más aún, poco productivo para la República. 
poeta, al ser inflamado por el furor divino, aplica sus conocimientos adquiridos artificiosamente, porque la Lectura no desea -o no puede- expresar la causa ${ }^{428}$.

Finalmente, en §.XIIII, "Del furor poetico, y si en los Poetas es permanente o transeu[n]te", se dice:

El vltimo furor con que el Poeta haze sus obras consiste en el concento sonido, proporcion y correspondencia, co[n] que las cosas se trauan, proporcionan y conrresponden que podemos llamar armonia, lo qual aprehendiendo el Poeta con su imagintatiua, viene a inflamarse el cuerpo, como con la ira, y con esta inflamación, y ardiente furor, casi desasido del espiritu, como fuera de si, viene a traçar y componer tanta variedad, no solo de versos y coplas, pero mil inuenciones altas y subidas, todas con sonora y admirable correspondencia y perfecta proporcion. (f. 207v)

La armonía renacentista, la proporción dentro de la variedad-misma que remite a la métrica, en donde la agudeza juega también un papel importante-, es producida por el furor poético, que afecta la imaginativa del poeta con su calor. Es decir, con la destemplanza ya mencionada -que no hará caer nunca al poeta en locura- se encuentran correspondencias armoniosas.

En este punto, quiero anotar la compleja propuesta de Carvallo, debido a que la destemplanza del sutil ingenio por el calor del furor poético se contiene y guía con el arte para crear obras armoniosas $^{429}$. Tal destemplanza, como suponía más arriba, no es permanente, aunque la aptitud -en este punto Carvallo personaje habla de la vena- está siempre en el alma del poeta, volviéndose incluso una potencia de esta ${ }^{430}$. No obstante, por una cuestión corporal -el cuerpo al que está sometida la potencia y el alma ${ }^{431}$-, "viene a estar vnas vezes mas apta y prompta para obrar" (f. 208v). Para que la vena obre es necesario - se insiste en la teoría fisiológica- un "calor del cuerpo, y su inflamacion" (f. 209). Incluso, de dicha inflamación dependerá la calidad de los versos y cantidad ${ }^{432}$.

La intervención corporal provoca que Carvallo, con base en Huarte y Cicerón, comente tanto el tipo de ambiente físico ideal, que "aprovecha mucho para el ingenio" (f. 209v), como el social -

428 Vid. loc. cit.

${ }^{429}$ Aurora Egido sintetiza muy bien las ambiciones del Cisne de la siguiente manera: "Carvallo compara la obra del poeta a la de Dios, pues aquel hace ficción y argumento de la nada. Pero a la hora de clasificar los furores, no sólo atiende al amor, al misterio y al valor profético de la poesía, sino a la proporción y armonía del furor poético. Extremo que nos obliga a ver las pautas de contención y equilibrio que la locura poética busca en curiosa paradoja y que no se comprende en otro tipo de furores desmedidos. Precisamente es en la proporción y en la armonía donde el poeta inflamado alcanza, según él, el logro de la creación artística. La natural inclinación es indespensable [sic], pero sin el arte y medida del intelecto no existe la poesía" ("La hidra bocal", art. cit., p. 85).

${ }^{430}$ Así lo afirma Lectura: "Lo que en esso me parece es, que la alma siempre tiene essa aptitud y potencia, para obrar cada ora y en cada tiempo, que quiera. (f 208v).

431 Carvallo usa la misma metáfora plátonica que Pinciano usa para justificar la diferencia cualitativa en los ingenios, pero el jesuita asturiano la interpreta para comprender el por qué la vena: "como està organizada en este cuerpo de barro subjeto a tantas influencias, passiones, y mudanças, por su causa, y disposicion” (f. 208v) no está siempre obrando.

${ }^{432}$ Lectura advierte: "vemos que algunas vezes ditara mas versos vn Poeta que pueda otro escriuir por estar la vena y furor en su punto, y otras vezes estarà tan resfriado, que no pueda hazer vno solo" (f. 209r). Nótese además cómo se usa la metáfora física del "resfriado" para continuar exaltando las razones fisiológicas de la creación poética, sin que esto suponga abandonar las capacidades divinas. 
mismo que recuerda a los principios propuestos por el Cortegiano de Castiglione, llevado a España por el Brocense-, "porque aunque el ingenio sea muy bueno, el hablar se quiere oyr y execitarlo" (loc. cit.). La importancia del diálogo es capital entonces para la formación y práctica del ingenio. El mismo Cisne es un ejemplo práctico de esto, puesto que a partir de una relación dialéctica surgen las reflexiones sobre la práctica poética.

Como resultado de la reflexión poética, se indica en el Cisne que la poesía y el arte poética no deberían ser inútiles para la República. No obstante, Lectura no niega que se puedan producir obras inútiles con ayuda del ingenio poético-incluso si este es delicado o agudo ${ }^{433}$; aunque, de ser así, la insignia de tales poetas es la "engañadora Sirena" (f. 211r). El jesuita reserva el emblema del cisne solo para su poeta ideal: el poeta moral que plica a conceptos provechosos su "ingenio, arte, $y$ trabajos" (f. 212r).

A continuación, quiero apuntar la denotación y las principales connotaciones que el ingenio tiene en el Cisne. Para Carvallo, el ingenio es una capacidad creadora, capaz de correlacionar dos elementos semejantes entre sí -símil- y está presente en todos los seres humanos. Además, la distinción entre este y el entendimiento -tan cercanos en el proceso creativo- es la imaginativa, que en el poeta se caracteriza por requerir calor. Esto corresponde a la parte fisiológica de dicha capacidad humanidad. Por otra parte, la relación entre ingenio-imaginativa y entendimiento es horizontal, en tanto que ningún se subordina a la otra. Sin embargo, Carvallo es consiente que el ingenio y su aspecto distintivo, la imaginativa, necesitan cierta mesura en sus expresiones y aquí es donde el entendimiento juega un papel imprescindible.

Ahora bien, en la imaginativa ya se nota un aspecto importante: el tipo de ingenio propio del poeta. Desde el principio de su poética dialógica, el profesor jesuita establece un prototipo de poeta y de poesía que deben enaltecer la insignia del cisne. La insignia engloba todas sus cualidades enaltecidas, principalmente su ingenio poético, cercano a la divinidad, que se obtiene por medio de otra capacidad del alma y un proceso externo: la vena y el furor poético, respectivamente. Ambos aspectos son fundamentales para que las capacidades natas en el ser humano-ingenio, entendimiento, juicio, entre otras- se eleven sobre el común y se acerquen a la divinidad. Cuando esto ocurre el ingenio se vuelve agudo, sutil y delicado, capaz de penetrar en conceptos sublimes. Estos, con ayuda de otras capacidades y hábitos, son convertidos con el ingenio poético insuflado en algo comprensible

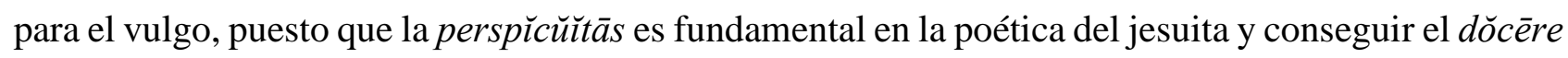
èt dēlectāre tan caros al jesuita.

433 "Y es lastima embilezcan aora la malicia de algunos Poetas vna arte de tanto prouecho para las Republicas. Y que hombres de tan agudos ingenios y tanta elegancia en el dezir, den con todo ello como dizen en vn barro" (f. 211v). Esta cita la he explicado con más detalle en el "Capítulo II". 
El ingenio poético acerca al poeta a la divinidad y le permite crear obras poéticas perfectas, siempre y cuando estén sea correctamente dirigido por el entendimiento y esté apoyado en el arte, la ciencia -'conocimiento'- y stŭd̆̌um. Así mantiene la armonía ideal. Por otra parte, como la rēs que recubre con verba es oscura por los misterios que encierra, enseña al receptor verdades superiores y morales. En consecuencia, el ingenio poético es fundamental para que la poesía cumpla con su misión moral y adoctrinadora. En otras palabras, de esta capacidad divinizada depende que sea útil para la República.

\section{Francisco Cascales, Tablas poeticas (1617)}

En el diálogo humanístico entre Castalio -voz autorizada- y Pierio -voz del neófito-, el término ingenio aparece únicamente en dieciocho ocasiones. A partir de este número reducido de menciones, diseminadas a lo largo de la poética ${ }^{434}$, comienzo a anotar lo poco importante que es el ingenio en el proceso creativo para Cascales. No obstante, existe también la posibilidad de que lo considerase algo puramente innato y por ello no creía oportuno darle un mayor seguimiento, como sí se podía dar a las reglas que rigen la imitación poética. El análisis de la poética permite encontrar ambas explicaciones, aunque es innegable que el primer caso es la principal razón del poco espacio dedicado al término. Antonio García Berrio parte de esto para leer las Tablas como una poética clasicista y contraponerla así a las poéticas manieristas como la de Luis Alfonso de Carvallo, que apelan más al aspecto divino e inventivo del poeta ${ }^{435}$. Sobre este punto regresaré más adelante, por ahora baste confirmar que, en efecto, la obra de Cascales se acerca más a la estética clásica, al preocuparse principalmente por establecer un arte.

Con base en lo anterior, ya en el "Prologo" el ingenio es una capacidad nata que necesita reglas. En su captāt̆̌o benevolentiae, dirigida al Poeta ya formado, Cascales justifica la necesidad de su poética porque "oigo a algunos demasiadamente confiados en su natural ingenio dezir: que como se puede nadar sin corcho, se puede ta[m]bien escriuir sin leyes. Braua presupcion, y vana confiança, y indigna de ser admitida" (s. pag.). Para su argūmentātı̌o, como ya había hecho Carvallo, el humanista murciano utiliza la pětītı̌o principi, ya que "basta dezir, que si confiessan que es arte la Poesia, (como lo es) q[ue] à de constar de preceptos”. En consecuencia, Cascales aconseja al aspirante

${ }^{434}$ El ingenio no aparece en tres de las cinco tablas "De la Poesia in specie": "De las Costumbres", "De la Sentencia” y "De la Diciton". Noto entonces cómo hay una notable distinción, por ejemplo, con la poética dialógica de Carvallo, en donde el término permeaba toda la conversación.

435 "Pero si alguno de los tratados españoles de Poética puede ofrecer claros indicios de una modernidad de signo manierista en el tratamiento de las ideas sobre el ingenio, es el interesante Cisne de Apolo de Luis Alfonso Carvallo, publicado casi en la divisoria de los siglos, en 1602. Lo que es decir, poco antes de 1604 en que se centra la redacción de las Tablas, y cuando los acontecimientos de la vida literaria española apuntan ya su decida inflexión a la estética nacional barroca" (Introducción a la poética clasicista, p. 175). 
a poeta: "consulta tu a los hombres versados, y practicos: oye sus preces, y con ellos escriue obras heroicas, scenicas, y lyricas, si quieres co[n] justo titulo ser saludado por Poeta" ("Prologo", s. pag.).

La preponderancia del arte sobre el ingenio es evidente desde las primeras líneas de las Tablas, porque este último no puede ser una capacidad que trabaje de forma aislada para la creación poética. El profesor de latín es claro: el aspirante a poeta -su poeta ideal, se podría agregar- necesita

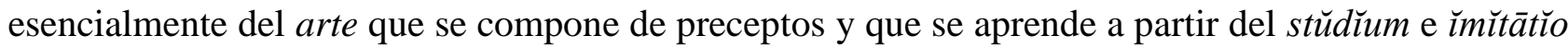
de auctoritates. Estas son modelos autorizados -"hombres versados, y prácticos"-, pertenecientes a un canon del que, en parte, se da cuenta a lo largo de las Tablas ${ }^{436}$. Cascales continúa entonces con la opinión más común de la tradición retórica española precedente, la cual ha sido identificada por García Berrio en un puntual excursus retórico. En este destacan las figuras de Antonio Lull y Juan Luis Vives por su carácter moderno que los distancia de una tradición que anteponía el arte al ingenio. Afirma el hispanista:

En el caso que nos ocupa ahora, además, la doctrina sobre la naturaleza del poeta había adquirido en algunos de ellos, como Vives y Lull, tal grado de lúcida modernidad, [...] que, tras de ellos, no puede hablarse sino de amortiguamiento tópico. En especial, cuando las consideraciones estéticas comenzaron a discurrir por las frecuentadas vías del eclecticismo, o bien por las del elogio del ars, de la enseñanza y la técnica bien aprendida -con detrimento explícito o tácito del ingenio- en las rutinarias apologías y elogios del arte respectivo, que solían ser incluidas al comienzo de todos los tratados. ${ }^{437}$

Es esta última precisamente la raigambre de Cascales. Sin embargo, en su caso, el detrimento del ingenio es más bien tácito, lo que explica justamente su poca presencia tanto en la Tablas como en el proceso creativo que estas exponen o, mejor dicho, prescriben.

La segunda aparición del término confirma esto. Al comenzar las Tablas, Castalio explica el motivo por el cual la poética de Horacio no puede ser considerada formalmente como tal ${ }^{438}$. En respuesta, el representante de la curiosidad del neófito afirma: "Quedo satisfecho en esta parte, y conte[n]tissimo por otra, vie[n]do camino abierto a mi deseo, y al de muchos buenos ingenios, que

${ }^{436}$ Sanford Shepard, al comparar las poéticas de Pinciano y Cascales, enfatiza en la dependencia que este último tiene de sus autoritates, mismas que les impone a sus lectores (vid. El Pinciano y las teorías literarias del Siglo de Oro, pp. 157-158). Shepard, sin embargo, no reconoce las fuentes italianas del humanista murciano y basa su crítica solo en los principios aristotélicos y horacianos. Pese a esto, y matizando el tono absoluto del crítico, es evidente que en las Tablas sí hay una importante presencia de argumentum ăd verecundiam tanto en la delimitación de preceptos como de modelos que, al ser descritos, se vuelven prescriptivos.

${ }^{437}$ Formación de la Teoría Literaria moderna. 2, p. 337-339.

${ }^{438}$ La afirmación de Cascales nace del modelo de poética que tenía, es decir, la Poética de Aristóteles, como indica García Berrio. Por el contrario, el Arte poética es solo una fuente de la que toma citas para sustentar un argumento aristotélico o incluso ciceroniano (vid. id., p. 149). Esto, empero, debe ser matizado, puesto que uno de los principales preceptos que guía a las Tablas es el decoro que, si bien ecléctico (vid. S. Shepard, op. cit., 158), tiene un fuerte eco horaciano. Por tal motivo, decir que la presencia de la poética de Horacio es "un esporádico y a veces perturbador rosario de citas ocasionales, muchas de ellas muy mal encajadas" (A. García Berrio, Formación de la teoría..., p. 149) resulta una aseveración cuestionable. De tal guisa, considero que el juicio de Víctor Fernández-Corugedo, aunque no del todo neutral por la afirmación del plagio, da una mejor percepción de la obra: "Las Tablas son una inteligente mezcolanza de la Poética de Aristóteles y el Ad Pisones de Horacio; un ejercicio de sistematismo didáctico y un mucho de plagio de comentarios de la preceptiva italiana, especialmente los de Robortello y Minturno" (op. cit., p. 282). 
en esta arte lleuan gran fruto cada dia" (pags. 7-8). Pierio ve un camino abierto, porque se le ofrece la oportunidad de preguntar la esencia, las características y los modos con los cuales se conforma la poesía. Además, la descripción de tales elementos ofrece preceptos que conforman un arte. Con esto, se asume que hay un "deseo" de aprender este último. Es más, para Cascales, el conocimiento del arte es una obligación de los ingenios que practican el arte poética, aún los buenos.

Lo anterior no se discute ni siquiera para alabar el ingenio español -tópico de las retóricas y poéticas de la época ${ }^{439}$, al que se le reprocha la falta de arte en la comedia nueva. Asevera así el conocedor de la auctōrițās:

Por cierto teneis mucha razon de alabar a vela tendida los ingenios Poeticos de nuestra era: mas como me saluareis el descuido grande (no quiero dezir ignora[n]cia) que los mas q[ue] la professan, tienen? Materia tenemos entre manos, por donde quien no cerrare de industria los ojos verà claramente mi verdad, y sus culpas. Y es lastima q[ue] falta del arte sea furto perdido el de su fecu[n]dissimo ingenio. (pag. 9)

Este desfavorable juicio sobre la producción dramática de la época se basa fundamentalmente en la falta de acuerdo que existe en entre las obras presentadas en los corrales y lo estipulado por los preceptos, aún y cuando los ingenios poéticos sean fecundísmos.

Es bastante claro que para Cascales el ingenio, sin arte, puede crear-se mantiene su pincipal denotación-; sin embargo, su producto no es más que "fruto perdido". La afirmación de las Tablas se contrapone con la del Cisne, en donde el stŭdı̆um asiduo del arte ayuda a crear, pero este, sin natural ingenio, no provoca deleite ${ }^{440}$. Ambas poéticas continúan y afirman dos criterios estéticos diferentes, sin que esto implique que, dentro de los mismos, el arte sustituya totalmente al ingenio o viceversa, como explico a continuación.

Para Cascales, el ingenio poético no puede asegurar por sí mismo la calidad óptima de su creación; sin embargo, su injerencia en el proceso creativo, si bien débil, no deja de ser necesario.

${ }^{439}$ Vid. A. García Berrio, Introducción a la poética clasicista, p. 273. Este tópico con la variante de ser "complejo de ignorancia doctrinal de los ingenios españoles" (id., p. 353) es identificado por el filólogo español en la "Tabla tercera. De la tragedia" de las "Tablas de la Poesia in specie", en donde Pierio cuestiona a Castalio la existencia de la tragicomedia. Sin embargo, pese a que García Berrio escribe "ingenios españoles", lo cierto es que los interlocutores comentan el entendimiento español: "Faltos de entendimiento? absit. Antes en caudal de entendimiento se auentajan a las demas naciones: Pero los Poetas extranjeros (digo) los que son de algun nombre, estudian el Arte Poetica, y sabe[n] por ella los preceptos, y obseruaciones q[ue] se guardan en la Epica, en la Tragica, en la Comica, en la Lyrica, y en otras Poesias menores. Y de aqui vienen a no errar ellos, y a conocer tan facilmente nuestras faltas" (pags. 332-333). Más adelante, Pierio pide información a Castalio sobre el soneto de esta forma: "Vamos, que yo lo desseaua por estremo; y espero de vuestro ingenio en este particular alguna cosa curiosa" (pag. 438). Con base en esto, considero que la identificación entre ingenio y entendimiento podría incluso ser posible, principalmente si nos atenemos al segundo caso, ya que el ingenio al que se refiere Pierio no es la capacidad natural que funciona como causa eficiente en la poesía, sino a los conocimientos que Castalio tiene sobre el tema. Sin embargo, es una mención aislada en una poética que no considera la capacidad receptiva del ingenio, como ocurre en la Philosophia o el Cisne. Así, considero que asociar ambos términos no deja de ser impreciso y confunde las funciones y características específicas de cada capacidad natural, aunque es innegable su estrecha relación. Además, entender que son términos diferentes permite enfatiza que para Cascales el ingenio no es una capacidad que pueda ser educada, sino que es el entendimiento quien lo guía, con ayuda de los preceptos.

${ }^{440}$ En esto se basa precisamente la crítica de García Berrio, para quien Carvallo había ofrecido una poética más moderna, innovadora y manierista, oponiéndola a la tradicional, clásica y poco propositiva poética de Cascales. 
Así se confirma en la primera "Tabla" "De la Poesia in genere" que trata de "de la diffinicion Poetica, de su materia, forma, y fin, de la diuision de las Poesias, de la diferencia, y co[n]cordancia dellas". Cascales en la voz de Castalio aclara que el género desarrollado por cada poeta está determinado por su natural ingenio:

Quien no es bastante para hazer vna obra Epica, ni vna Tragedia, haga Comedia, o haga vna Egloga, vna Satira, vna Cancion, o vn Soneto. Examinese tambien adonde le lleua mas su inclinacion. Porque aura quien no acierte a darle su gracia a vna Comedia, y habra vna Tragedia por estremo bien. Otro tendra excelencia en la Epopeia, y no en la Lyrica. Por tanto conuiene experimentar cada vno su natural ingenio para mejor acertar. (f. 24)

Con un evidente eco de los versos del Arte poética (vv. 38-40) y de la Poética de Aristóteles (1456a 3-7), el humanista murciano contempla tres aspectos del ingenio -uno de ellos ya indicado con anterioridad. El primero es su carácter natural, que no puede educarse, porque se trata de una “inclinación” individual -similar a lo que ocurre en la poética de Carvallo. El segundo aspecto establece que la función del ingenio está directamente relacionada con la creación poética y es entonces su causa eficiente -por decirlo en términos aristotélicos. El último aspecto observa que el tipo de género al que esté naturalmente inclinada la obra del poeta se debe a la cualidad individual de su ingenio, con lo que se le supedita a la "ley del decoro". Hay por tanto una imperante necesidad para que el poeta sea consciente del tipo de ingenio que posee y a qué sea propenso: épica, tragedia,

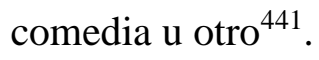

Hay que agregar que, pese a la importancia de tal aspecto ${ }^{442}$, Cascales nunca especifica cómo debe descubrir el poeta su propio ingenio, por lo que sostengo que tal capacidad natural pertenece a un ámbito empírico que no puede ser sujeto a preceptos. En otras palabras, el natural ingenio de Cascales no puede ser descubierto o educado con ayuda del arte, ya que el poeta debe "experimentar" de forma individual para comprender con qué tipo de ingenio se le ha dotado. Arte e ingenio están aquí totalmente diferenciados, con una notable relación de subordinación, en la que se insiste más adelante, pero con ciertas particularidades.

${ }^{441} \mathrm{El}$ natural ingenio del poeta precisa la materia y género poético que debe ejercer. Por tanto, puede suponerse que dentro de dicho ingenio se está considerando un tipo particular, por ejemplo, para la tragedia. No obstante, en las Tablas no hay ningún indicio para que se pueda hablar o definir un ingenio trágico, sino que existe una tendencia natural a tal materia y género que el poeta debe seguir para perfeccionar su obra. Cascales reduce al mínimo la disertación sobre el ingenio, no solo por su apego a las fuentes, sino por una iniciativa propia a silenciar lo más que se pueda la causa eficiente de la poesía.

${ }^{442}$ Esta misma idea se repite durante "Las Cinco Tablas de la Poesia in specie. Tabla primera. De la Epopeia": "No sola vna obligacion es la que tiene el Poeta, a muchas cosas mira, y esta es vna de las principales. Y ante todo ha de considerar, que tan valiente se halla, y medir co[n] prudencia lo que su ingenio alcança: si no vale para escriuir vn Poema Epico, y Tragico, haga vna Comedia; sino para vna Comedia, haga vna Satira, vna Ecloga, vna Elegia, vna Cancion, vn Soneto, vnas Redondillas; q[ue] en el conocimiento de si mismo consiste la discrecion, y mayor virtud del hombre" (pags. 266-267). En breve, el poeta tiene la obligación de conocer su propia capacidad poética, lo que es equivalente a desentrañar a qué tipo de género poético tiende su ingenio. 
En la "Tabla segunda. De la Fabula", Castalio vuelve a establecer la dependencia que el ingenio tiene con el arte, porque "la naturaleza humana sin arte, no puede hazer obra perfecta" (pag. $82)^{443}$. No se discute el carácter creador del ingenio, pero se pone en entredicho el valor estético de su producto. Además, se reprende nuevamente a los poetas que privilegian el ingenio. Sin embargo, quiero enfatizar que en esta ocasión es por pretender usar tal ingenio para crear una nueva poética. Cascales se refiere claramente a la comedia nueva ${ }^{444}$ y a la nueva poesía, encabezada por la prominente figura de Góngora.

Y si ay algunos q[ue] estudien en inuentar nueua arte Poetica, me parece que van buscando frondosos arboles, y verdes jardines, en las arenas de Etiopia. [...] Y si bien esos por mostrar que valen mucho, con su ingenio, y doctrina pretenden introducir nueua Poetica en el mu[n]do, al fin no seràn de tanta autoridad, que se deua creer antes á ellos que a Aristoteles, y Horacio. Y si el arte enseñada destos viene bien co[n] la Homerica, y Virgiliana Poesia, yo no veo porque se aya de llamar vna diuersa de otra: porque la verdad vna es; y lo que vna vez es verdadero, co[n]uiene que lo sea siempre, y la difere[n]cia de tiempos no lo muda. (pags. 8283)

El pasaje ${ }^{445}$ evidencia la inclinación por los preceptos de la poética de Aristóteles y Horacio y privilegia la ı̌mítāť̆o de los modelos clásicos. De tal manera, Cascales demerita toda necedad de creación de nuevas poéticas basadas en los ingenios de poetas. Estos, pese a ser tan fecundos para crear nuevas doctrinas, no poseen validez alguna e, incluso, pueden ser acusadas de falaces ("'porque la verdad vna es"). Quiero observar, además, que esta mención implica un ingenio no restringido a la creación poética. El humanista ahonda en la capacidad creadora innata del ingenio, lo que permite al poeta la elaboración de nuevas poéticas, porque su misma obra pretende crear "Homerica y Virgiliana Poesia". En otras palabras, "algunos" aspiran a ser nuevos modelos de stǔd̆̌um e ı̌mĭtāť̌o, lo que crearía una nueva arte poética, siguiendo lo estipulado por Cascales en su "Prologo".

Sutilmente, aunque se mantiene el objeto sobre el cual se aplica-la poesía-, el ingenio en las Tablas no es ya únicamente una capacidad para la inventǐo poética, sino también para la creación de sus normas. La relación entre arte e ingenio no es totalmente opuesta, sino que el segundo se encargaría incluso de la creación del primero. En este momento, Cascales descontextualiza y

${ }^{443} \mathrm{Si}$ bien es cierto que no aparece literalmente el ingenio, ya se ha establecido que Cascales acepta la larga tradición -no podría ser de otra manera- y considera que el ingenio es una cualidad innata del ser humano; es decir, forma parte de su "naturaleza humana".

${ }^{444}$ De esta opinión es Fernández-Corrugedo (vid. op. cit., p. 284).

${ }^{445}$ Una pormenorizada ilustración del mismo se puede leer en el estudio hecho por García Berrio (vid. id., pp. 161-176). Este considera un fragmento más extenso del texto que cuestiona que se llame poetas tradicionalmente a Ovidio y Boccaccio. El comentario del filólogo español hace un especial hincapié en el ingenio como causa eficiente de la poesía, ya que observa en la preferencia de Cascales por la poética clásica una forma de circunscribir la naturaleza del ingenio, con lo que niega las innovaciones de la comedia nueva, por ejemplo.

Los juicios de García Berrio con respecto a la poética son categóricos y anulan cualquier cualidad digna de encomio a las Tablas, restándoles así valor crítico o reflexivo. Sin embargo, opino que el mismo clasicismo de Cascales permite ver con claridad el extremo de una de las posturas de la polémica gongorina y lopista, por lo que, pese a ser poco innovadora, no debe ser descartada. 
resignifica su fuente directa $-L$ 'arte poetica de Minturno ${ }^{446}$. Asimismo, como cultivador del clasicismo y consciente de la gran capacidad del ingenio, subordina el ingenio de sus contemporáneos a un arte de raigambre clásica, pero no solo.

Como se nota en las fuentes que nutren la Tablas, Cascales aprecia en la práctica y en la teoría la escuela italiana. Lo último lo observo también en cómo se considera a Ariosto, quien es "ingenioso" (pag. 312), en tanto ofrece un modelo de imitación estilística para la sátira, como se explica en la “Tabla segvnda. De las Epicas menores", perteneciente a las “Tablas de la Poesia in specie”. Aunado a esta auctōritās italiana, en la "Tabla Qvinta. De la Poesia Lyrica", Castalio afirma que las canciones de Petrarca han sido "hechas con admirable artificio, y singular ingenio", por lo que se aconseja inmediatamente al poeta: "Rebolued su Cancionero, que mejor se aprende esto que digo a vista de ojos, que con preceptos" (pag. 434). Confirmo la preferencia de Cascales por ciertos autores italianos.

Por otro lado, en el consejo de Castalio se confirma que el ingenio -visible en las creaciones poéticas por medio del estilo- puede ser un creador de preceptos, es decir de arte. No obstante, para Cascales, los preceptos ofrecidos por los modelos clásicos e italianos son ideales y por ello el ingenio español debe guardar el decoro de estos. Se explica así que apenas se mencione el término ingenio y que exista entonces una deliberada falta de desarrollo del mismo término ${ }^{447}$.

Cascales percibe que el ingenio puede crear un nuevo ars poetriae. Tal motivo lo insta a preferir destacar una y otra vez el arte clásico, el cual no "afila" el ingenio, sino que lo encierra en determinados preceptos para guardar el decoro. Y, para reafirmar tal autoridad, Cascales utiliza también motivos estéticos y éticos. Como anoté más arriba, Castalio pone en duda tanto la calidad de la creación poética realizada únicamente con ingenio, como la veracidad de los nuevos preceptos que dicha obra crea, desoyendo los preceptos de los clásicos.

${ }^{446}$ Como he hecho a largo de mi trabajo, los pasajes que se toman de fuentes directas e indirectas los interpreto únicamente en la medida en la que se introduce en la poética del murciano y a partir de esta, aún y cuando se trate de una traducción literal de su hipotexto, como, por ejemplo, la poética de Minturno._Sin embargo, considero de gran importancia un nuevo estudio sobre las fuentes de las poéticas, que responda a qué es lo que están traduciendo y por qué.

La poética de Casales me parece ejemplar para demostrar dicha necesidad. Como observo en este pasaje, pese a ser una tradicción ăd litteram como Benito Brancaforte demuestra (vid. F. Cascales, Tablas poéticas, B. Brancaforte ed., pp. 61-62), no solo está indicando -en palabras de García Berrio- "las preferencias de Cascales como lector" (Formación de la teoría literaria. 2, p. 368). El humanista murciano descontextualiza en muchas ocasiones sus fuentes, se apropia de ellas y crea una poética propia -misma razón por la cual realizo mi estudio únicamente a partir de la poética española y no en relación con su hipotexto. De tal forma, pongo en evidencia la falta de un estudio que aplique la metodología propuesta por Margarete Newels en donde "lo importante para la interpretación de los tratados que conocemos es identificar las fuentes, los autores de éstas, y, si se trata de fuentes modernas, determinar en qué fuentes antiguas se basan a su vez. Solo procediendo de este modo podremos poner de manifiesto los distintos matices de las diversas teorías. La suma de estas fuentes, junto con la aportación personal del autor -y la selección de fuentes es ya una aportación personal, tienen como resultado nuevas teorías con características bien individuales" (Los géneros dramáticos en las poéticas del Siglo de Oro, p. 88).

${ }^{447}$ El arte llega a tener tal dominio sobre el proceso creativo que, durante las "Cinco Tablas de la Poesia in specie", Castalio dirá a Pierio después de explicarle las reglas métricas de la canción: "Sabiendo esto ya podreys atreueros a inuentar vna Cancion con las partes dichas" (pag. 418). 
Las consideraciones hechas son extensivas a la vena y furor: términos que no se definen, que se confunden entre sí y que nunca se relacionan directamente con el ingenio. De hecho, ambos -a diferencia de este último-son únicamente expuestos en una breve digresión durante la "Tabla Qvinta. De la Diction" como tópicos y parodiados en consecuencia ${ }^{448}$.

Pierio. Ya con esta lection sabre yo hazer vn verso, si la vena me ayuda.

Castalio. Guardeos Dios de hazer vn verso, que hecho vno, os podreis aparejar para cien mil. No [h] e visto facultad mas atractiua, y menos prouechosa. El entendimiento corre tras ella ansiosissimo, y parece que està en su centro quando se ocupa en Poesia que como el tiene tanto de diuinidad, y la Poesia es furor diuino, viue en su reyno quando discurre sobre Poeticos sugetos. Y de aqui les viene a los Poetas ser tan pobres; que como el oro, plata, y hierro estan en las profundas venas de la tierra, y ellos se tranmo[n]tan al alto cielo, pierden de vista la pecunia necesariamente. (pags. 185-186)

La vena y el furor se identifican entre sí y son una facultad "atractiua y menos prouechosa". De tal guies, Cascales les niega toda función en el proceso poético y se les separa del ingenio, que sigue siendo la causa eficiente de la poesía pese a estar sometido al arte.

Por otro lado, la figura del cisne-poeta de Carvallo es desacralizada. La vena o el furor no determinan el carácter divino de la poesía -el cual se afirma más adelante totalmente independiente de ambos estados-, así como tampoco se lo asocia con el ingenio. La divinidad poética se define como una cualidad inmanente de la poesía que ayuda a determinar el estilo que debe prevalecer en esta, sin que se profundice en su causa. De hecho, me parece que tal divinidad no reduce la distancia entre el ser humano y lo divino; no crea una relación entre el profeta y el poeta como ocurre con Carvallo; y tampoco está relacionada con una destemplanza de los humores como explica Pinciano. La divinidad poética de Cascales es más bien formal porque el habla del poeta se contrapone con el habla elevada del ser humano común. En breve, es una divinidad estilística ${ }^{449}$, lo que recuerda que el ingenio de los italianos debe ser observado por los poetas en su estilo.

Hasta aquí, la causa eficiente parece ser la única vía que el ingenio tiene para trabajar en la poética de Cascales. La dispǒš̆tĭo, que Carvallo también había considerado como tarea del ingenio, se encarga al juicio, quien mantiene el decoro -cual freno racional del ingenio. Así ocurre, por ejemplo, con la decorosa disposición de las frases con respecto a la calidad de la persona ${ }^{450}$. Por el

${ }^{448}$ Vid. A. García Berrio, Introducción a la poética clasicista, p. 256-57.

449 "Es la Poesia vna cosa diuina, y assi la baxeza desta diuinidad frisa con[n] la altura del estilo humano. Puestos ya en el cielo de la Poesia, emos de imaginar tres grados, vno mas alto que otro" (pags. 202-203). En todo momento, Castalio está hablando del estilo poético.

${ }^{450}$ Después de afirmar la divinidad estilística del poeta, Castalio comenta: "lo segundo a que se à de mirar es el decoro de la persona del q[ue] habla, y del que oye; la edad, si es moço, o si es viejo; la profession, si es philosopho, gouernador, o soldado; el genero, si es varon, o si es hembra; la materia, si es graue, o si es humilde. En todo esto entra el juizio del buen Poeta, y con esto ha de acomodar las Phrases conuenienteme[n]te" (pag. 203). Esto relacionaría a Cascales con una parte de la tradición que contraponía el ingenio al juicio, como consigna Mercedes Blanco (vid. Les Rhétoriques de la Pointe. Baltasar Gracián et le Conceptisme en Europe, pp. 30-32). 
contrario, la función activa que el ingenio tiene en la inventǐo se reafirma en las "Cinco tablas de la Poesia in specie", "Tabla tercera. De la tragedia".

Durante esta parte de la conversación, se señala que la creatividad del ingenio se entorpece si los hechos históricos escogidos por el poeta son demasiado grandes. Avisa Pierio: "Bien se ve que tomando el Poeta vna action ta[n] larga, lleua las cosas muy atropelladas, corriendolas al galope, sin dar lugar al ingenio" (pag. 347). Esto es confirmado por Castalio, quien asegura que la imitación de una acción breve evita que el poeta cometa faltas en la coherencia lógica entre los eventos representados en las tragedias y comedias, además de permitir al ingenio inventar. En consiguiente:

la Comedia, y la Tragedia no pueden abraçar action grande, ni tienen licencia de dexar lagunas, y espacios entre el principio de la action primaria, y su fin; y siendo la action principal corta, fuera de que puede ser imitada y representada con descanso, y a sabor del ingenio Poetico, se pueden traer co[n] facilidad episodios para ornamento de la Poesia y delectacion de los oye[n]tes. (pags. 348-349)

Esta es la primera vez que Cascales califica de poético al ingenio y su objetivo es bastante preciso: la creación de los episodios que son ornamentales para la poesía y cuya función es deleitar al oyente ${ }^{451}$. Por tanto, el ingenio poético da "sabor" al género dramático, aunque este no nace de la "action primaria" -procedente de la historia ${ }^{452}$ - sino de los episodios, elementos secundarios y ornamentales $^{453}$. En otras palabras, el campo de invención del ingenio poético se reduce a los episodios y su participación en el binomio dōcēre-dēlectāre se centra en el segundo.

Hasta el momento, las Tablas han procurado enmarcar las tareas del ingenio y supeditarlo a los preceptos clásicos; sin embargo, pese a mantener este propósito, le otorgan un nuevo valor durante la "Tabla qvarta. De la Comedia", restableciendo parcialmente su importancia en el proceso poético. Aquí se afirma que la retractio es una "prueua de ingenio no mala, pues la competencia es piedra aguzadera, donde se afilan los entendimientos, y caudales de cada vno” (pag. 366). Ya he referido más arriba mi lectura de la competencia de ingenios como piedra aguzadera de los caudales del poeta (vid. “Capítulo II"). Con base en esto, ahora solo me gustaría enfatizar que la relación activa entre los diferentes ingenios innova los modelos clásicos y permite a los poetas apropiarse de estos, a la vez que forman parte de su tradición y la continúan. Por supuesto, tales efectos del ingenio se notan

${ }^{451}$ Sobre estos ya había tratado en la "Tabla segunda. De la Fabula", donde señala la cualidad de los episodios como "ornato" de la poesía. Cascales prescribe su creación y asociación con la acción principal para volverlos imprescindibles a la fábula, aún y cuando son en principio elementos ornamentales y ajenos a la trama principal (vid. pags. 74-75). Sin embargo, en ningún momento Cascales refiere al ingenio poético como el encargado de su creación o disposición dentro de la fábula.

${ }^{452}$ La razón de preferir un argumento tomado de la historia responde al objetivo persuasivo que para Cascales debe tener la poesía, principalmente la que trata argumentos graves como la épica y la tragedia: "mas persuaden, y mueue[n] las cosas que sabemos auer pasado, y sucedido realmente, que no las que fingimos" (pag. 46). Es más, la distinción entre historia y poesía obedece a que, tratando el mismo hecho, la primera narra y la segunda imita (vid. pags. 45-58, passim).

${ }^{453}$ El profesor de latín enfatiza una vez más las posibilidades inventivas que ofrecen los episodios en la Tabla dedicada a la comedia, pero sin mencionar al ingenio poético (vid. pags. 364-365). 
siempre en los episodios, porque, al retomar los argumentos de las comedias de Terencio o Menandro -la "action primaria"-, lo que puede variarse son los mencionados “ornamentos". La labor del ingenio está restringida una vez más a los elementos secundarios.

A continuación, el ingenio adquiere en las Tablas otra connotación de una raigambre clásica. Cascales relaciona a esta capacidad nata con una característica arquetípica de un oficio ${ }^{454}$, que los personajes cómicos deben guardar para conservar el decoro. De tal manera, Castalio recuerda que para conocer el "natural ingenio, y vida" (pag. 383) del alcahuete se debe recurrir a Terencio y Plauto. Entiendo aquí "natural ingenio" como el ingenio que es propio del alcahuete, por lo que no hay una relación con el fenómeno poético, pero sí con la teoría huartiana de los diferentes tipos de ingenios. Esto me parece muy significativo porque en el hipotexto de las Tablas -la poética de Minturno- no se encuentra tal referencia ${ }^{455}$. Por tanto, es posible rastrear en la poética del humanista murciano una mención de dicha tipología huartiana, que pudo haber tomado del mismo tratado del español o bien de la Philosophia o de otra fuente, sin ser del todo claro debido a la falta de un mayor desarrollo.

La siguiente mención, relacionada con la risa cómica, también la he comentado parcialmente en el capítulo anterior (vid. "Capítulo II") y las conclusiones que se han propuesto para la agudeza pueden ser extensivas para el ingenio. Es decir, la "risa maliciosa, aguda, ingeniosa, fundada en la fealdad, y torpeza agena, assi de cosas, como de palabras” (pag. 388) y los métodos con los que se consigue esta -turpǔtūdo ět déformütās- no pueden ser identificados plenamente con los mismos adjetivos. Pese a esto, tampoco puedo negar que pueda tratarse de una risa ingeniosa porque tanto las "cosas" - la rês-como las "palabras" -la verba-son asimismo ingeniosas. Nuevamente, la brevedad con la que Cascales expone tanto sus conceptos como sus métodos no permiten llegar a una afirmación absoluta. Sin embargo, considero importante retener la relación que el ingenio guarda con el artificio, pues esta se recupera más adelante.

Las últimas tres menciones del ingenio están en boca de la autoridad de Castalio para definir el soneto en la "Tabla qvinta. De la Poesia Lyrica". Sobre este se dice que es la "Poesia mas comun que oy tiene España, y aun toda la Christianidad [...]. El docto, y el indocto, quienquiera, se atreue a poner las manos en el sagrado Soneto, sin creer que por ello, el que no està ordenado del diuino Apolo queda irregular, y excomulgado ipso iure” (pag. 438). Tal afirmación recuerda al lector que la divinidad poética de Cascales está relacionada a cuestiones de estilo y, en este caso, al arte en sí, puesto que solo quien esté "ordenado del diuino Apolo" puede tratar con el soneto sin quedar "irregular".

${ }^{454}$ Vid. García Berrio, Introducción a la poética clasicista, p. 395.

${ }^{455}$ El crítico Benito Brancaforte señala que este fragmento, como otros muchos, es una traducción de la poética de Minturno y transcribe: "Che direm del ruffiano? Qual sia la natura, e la vita di lui, attissimamente da Terenzio negli Adelfi, e da Plauto nel Pseudolo vi si describe" (F. Cascales, Tablas poéticas, B. Brancaforte ed., p. 216, nota a la línea 7). 
El conocimiento semántico y métrico del soneto permite en consecuencia su exitoso resultado, que se compone a partir de un solo concepto, resuelto en un "determinado numero d[e] versos" (pag. 439). Ahora bien, mencioné en su momento que el ingenio se relaciona indirectamente con la agudeza (vid. "Capítulo II"), puesto que el soneto para el humanista murciano es también "dulce, ingenioso, y agudo" (pag. 443). Las razones de su agudeza ya han sido expuestas, por lo que me enfocaré a continuación en las razones que Castalio da para que sea ingenioso. Este anota:

Sera ingenioso el Soneto que lleua algun particular artificio, o disposicion, como el q[ue] se hizo en la muerte de la Reina doña Margarita de Austria: Mucho a la Magestad sagrada agrada, Y como otros que tocan arriba diuersas cosas, y al cabo las recoge todas. Y sin estas otras muchas maneras, que el ingenio es vn espaciosissimo campo. (pags. 443-444)

A diferencia de lo que ocurre con la risa cómica, el ingenio en esta ocasión sí puede ser ligado al artificio y, además, a cómo se dispone la materia poética. De tal guisa, como en el caso de Carvallo y por única vez en las Tablas, el ingenio se extiende de la invenť̌o y a la dispǒsĭtı̆o, mismas que son consideradas para llamar al soneto ingenioso. En el ejemplo ofrecido, un reconocido soneto en eco ${ }^{456}$, el tópico de memento mŏri se reformula tanto semántica como métricamente a lo largo de los doce versos. Por un lado, tal tipo de soneto demuestra la capacidad inventiva del ingenio, porque aquí, al igual que ocurre con los episodios del género dramático, se parte de un concepto único que será ornamentado con temas secundarios que apoyan y desarrollan el tema principal. En otras palabras, hay una amplǐfícātǐo semántica, como bien indica García Berrio ${ }^{457}$. Por otro lado, el ingenio interviene también en la distribución de las amplificationes a lo largo de los cuartetos y tercetos que integran la constante forma del soneto ${ }^{458}$, con lo que ofrece la vărīăť̆o poética. El ingenio ofrece un "espaciosissimo campo" a la breve forma del soneto.

Considero probable que la potencialidad del ingenio observada por Cascales en el género dramático y el soneto revitaliza el término al final de las Tablas. En consecuencia, lo libera parcialmente del yugo del arte, aunque la sombra de este siempre se encuentra presente. Así, por ejemplo, para la creación del soneto es necesario ser “ordenado del diuino Apolo", es decir, estar instruido en el arte de tal forma métrica, ofrecido precisamente por Cascales en su poética.

\footnotetext{
${ }^{456}$ El soneto ha sido atribuido a Fray Luis de León y sobre este escribió Antonio Alatorre: "Este soneto fue, con razón, sumamente famoso. Es una brillante hazaña técnica y al mismo tiempo una grave meditación sobre lo efímero de las glorias terrestres. Se escribió con motivo de la muerte (1580) de la cuarta mujer de Felipe II. El artificio tiene el antecedente del eco (Poliziano y Serafino), pero en Italia no hubo sonetos como 'Mucho a la Majestad sagrada agrada...'. No hay aquí preguntas y respuestas, sino discurso continuo y coherente. [...] El soneto en eco, género netamente español, se cultivó con no pocas variaciones durante más de un siglo" (Fiori di sonetti /Flores de sonetos, p. 171).

457 “A propósito de las ideas de Cascales y de sus posibles fuentes en torno al soneto, sorprende la profunda intuición que manifiestan sobre su estructura. En primer lugar, la clara percepción de su estructura semántica. El contenido del soneto se refiere a un solo tópico, o a un concepto, como desde Dante repetían los preceptistas. De tal manera que la aparición en el texto, casi siempre como expansiones o amplificaciones de ornato, de temas secundarios, no debía alterar la perspicuidad y consistencia del tema central" (Introducción a la poética clasicista, p. 450). A las palabras del crítico solo cabría agregar precisamente que tales expansiones o amplifaciones son debidas al ingenio.

${ }^{458}$ Esto mismo es señalado por García Berrio (vid. loc. cit.).
} 
Después de estas observaciones, es evidente que el ingenio para Cascales debe estar en todo momento subordinado a los preceptos ofrecidos por el arte y la tradición clásica e italiana. De esta forma, el humanista evita con sus preceptos que el poeta incurra en faltas contra la "ley del decoro". Pese a esto, se considera en todo momento su capacidad natural y creadora que debe estar centrada en los episodios de los géneros dramáticos y en los temas secundarios del soneto, donde su cualidad más importante es más reconocida.

No me gustaría terminar este apartado sin hacer énfasis en que la restricción del ingenio a la inventǐo de elementos ornamentales y su constante omisión en diferentes momentos de la creación poética responde a la estética preferida por el murciano. Esta, de hecho, se opone firmemente a las novedades poéticas de sus contemporáneos que privilegian el ingenio y con el cual empiezan a crear un nuevo ars poetriae. Sin estar presente, el gusto barroco se siente en las páginas de las Tablas poeticas.

\section{POÉTICAS DISCURSIVAS}

Luis Carrillo y Sotomayor, "Libro de la ervdicion poetica" (1611)

Señalé en el capítulo anterior que la primera poética discursiva de este análisis es el "Libro" y que, a diferencia de las poéticas dialógicas, no posee un diálogo explícito entre dos o más personajes. Así, de la voz de Carrillo y sus fuentes grecolatinas y humanistas, el ingenio es enunciado doce ocasiones. Su presencia cuantitativa es notablemente inferior a las poéticas dialógicas de Pinciano o Carrillo, aunque no debe pasar inadvertido el número de folios de cada una de estas. De hecho, las menciones en la poética de Carrillo son bastante cercanas a las de Cascales, pese a la extensión de esta última. Por lo tanto, su reducido número no es en este caso indicativo de mayor o menor atención a la capacidad innata. Es más, si partimos de una apreciación cuantitativa, puedo incluso decir que el ingenio en el "Libro" tiene un papel aún más importante que en la Philosophia o que en el mismo Cisne -la poética que más tinta ha dedicado al ingenio hasta ahora en mi estudio- ${ }^{459}$, lo que no es completamente correcto.

Ahora bien, en cuanto al significado de estas doce menciones es importante considerar que cada una de ellas está relacionada directa o indirectamente con el título del discurso carrillesco: la "ervdicion poetica". El sintagma entonces no solo sirve de hilo conductor, o leitmotiv, sino que determina la verdadera preocupación teórica del joven poeta, por lo que es importante ahondar en este. Según el Diccionario de Autoridades, la erudición es "Doctrína, disciplína escogida y

${ }^{459} \mathrm{Si}$ repetimos el ejercicio realizado con el Discvrso para el término de agudeza, en promedio, la palabra ingenio aparece una vez cada dieciséis folios en la Philosophia, una casi cada siete folios en el Cisne y una cada veinticinco en las Tablas. En contraste con esto, en el "Libro" se menciona literalmente al ingenio cada cinco folios. 
selecta" ${ }^{460}$. Entonces, cuando Carrillo la asocia a "poetica" -entendida siempre como el arte que se adquiere para la creación poética ${ }^{461}$ - construye un binomio que asegura las bases para una propuesta estética destinada a una minoría. De hecho, esta poética discursiva "obliga [al poeta] a profanar sus no comunes secretos" ( $M_{1}$ f. 110r.), con la finalidad de defender a lo largo de su "disputa" (loc. cit.) la poesía erudita ${ }^{462}$ de los ataques de aquellos que no pertenecen a dicho grupo selecto ${ }^{463}$.

Lo anterior se observa en el mismo título de la obra: "LIBRO DE LA ERVDICION Poetica, ò lanças de las Musas contra los indoctos, desterrados del amparo de su deydad" $\left(M_{1} \mathrm{f} .109 \mathrm{v}\right)^{464}$. Junto a este binomio que encabeza el arte de los doctos, se dice que aquellos contra los que se lucha no solamente son tales por 'falta de estudio', sino porque están “desterrados del amparo de su deydad": no son protegidos de las Musas. Con base en esto, ¿acaso el poeta ideal de Carrillo tiene una capacidad divina? O, más bien, ¿el amparo de las diosas es obtenido a través del stŭdŭum de la doctrina poética? La revisión de la función que el ingenio tiene durante la inventǐo ayuda a dilucidar la cuestión.

Ahora bien, quiero advertir que Carrillo y Sotomayor se aparta del binomio arte-ingenio, en tanto que ninguno de los dos es colocado por encima del otro o trabajan en conjunto. Así pues, ambos funcionan bajo el binomio erudición poética, con sus respectivas peculiaridades. De esta forma, el cuatralbo está superando la estética renacentista que regía a las poéticas dialógicas. En el "Libro" no se anota solo un cambio de término (arte-ingenio por erudición poética), sino una propuesta que apuesta por un racionalismo místico perfectible. Por ende, Carrillo -él mismo un poeta- se acerca a la creación de sus contemporáneos, próxima a aquella que García Berrio considera como una poesía nueva inaugurada por la pluma de Góngora ${ }^{465}$.

${ }^{460}$ Diccionario de la lengua castellana..., s. v. erudición.

${ }^{461}$ Es indispensable entender que esta poética no es la misma que la descrita por las poéticas dialógicas, sino que, literalmente es la poética de la erudición. Es decir, se ofrecen los preceptos que el poeta erudito debe poseer.

${ }^{462} \mathrm{Me}$ refiero con poesía erudita a la creación poética que responda a los preceptos enunciados por Carrillo. Este término, hasta donde tengo conocimiento, no ha sido usado anteriormente para analizar el contenido del "Libro", sin embargo, considero que su uso es pertinente e incluso necesario, puesto que es el resultado de la poética. Sobre esto ahondaré en este apartado.

${ }^{463}$ No quiero dejar de anotar la relación que esto guarda con la "familia o descendencia de poetas" que aparece en el Cisne.

${ }^{464}$ Con base en esto, si se quitan los juicios categóricos y reduccionistas, la afirmación de José María de Cosío sobre el "Libro" es bastante acertada: "No es sino una glosa difusa del verso de Horacio, Odi prophanum vulgum, et arceo, mil veces citado antes y después, y expresamente transcrito por Carrillo en su libro" (Fábulas mitológicas en España, p. 301). Por supuesto, la poética discursiva es más compleja que una "glosa difusa", aunque no se niega que el principio horaciano rige su estética.

465 Para el hispanista, la poesía gongorina es una "nueva poesía plenamente configurada y absolutamente divergente de la anterior en sus mecanismos de actuación; pero sin intención de variar en lo relativo a sus últimos productos en el seno de la sentimentalidad poética. Con esa poesía se estrenaba también, como es lógico, una novedosa autoconciencia del poeta, de su relación con sus materiales de palabras e imágenes, y de sus débitos al auditorio, a su público" (Formación de la Teoría Literaria moderna. 2, p. 390). Por el contrario, niega esta posibilidad revolucionaría a los teóricos coetáneos, al estar afianzados en mayor o menor medida a la preceptiva clásica-renacentista, es decir, a aquella estética que guiaba a la vieja poesía: "sus apologistas, sus comentadores, y hasta sus detractores no disponía de otro vehículo para exteriorizar el misterio que el que les brindaba la tradición en torno al debate secular sobre la índole del creador literario en la polaridad clásica ingenio-arte; o, si se quiere, en su desarrollo popular de si el poeta nace o se hace" 
A propósito de la cuestión mística, es innegable que el joven poeta, como heredero y digno continuador de una tradición encabezada por figuras como la de Herrera y Alonso de Carvallo, privilegia la figura del poeta divino. Esta, en el Cisne, se encuentra cercana a los profetas y aquí a los mártires, aunque Carrillo no resalta dicha comparación a lo largo de su "Libro", como sí lo hace Carvallo, en donde la ambivalencia poeta-profeta funciona como leitmotiv. Además, en el caso de la poética discursiva la relación es más compleja, puesto que obedece tanto a la figura del poeta como a la del poeta-soldado, en concordancia con la biografía del cuatralbo ${ }^{466}$. Sin embargo, la aproximación a lo divino posee varios matices, que indican la tendencia carrillesca al debilitamiento del arte-ingenio en aras del concepto de erudición poética.

Afirma el joven poeta:

el mismo Dios en la virtud de sus escogidos varones las rudas lenguas de embidiosos, mostrò, o ya fuese mayor virtud que humana, o a nuestra flaqueza gloriosissima, caer en vn mismo entendimiento la ciencia de contemplar, y el animo de pelear [...]. Tambien los Martyres, ò fuesse ya aficion suya, o el espiritu encendido de Dios, despreciando los fuegos, y el tormento, cantaron himnos, ni solo en este espiritu ygualaron a su alegria su amor, sino en las alabanças su desseo. ( $M_{1}$ fols. $\left.110 \mathrm{v}-111 \mathrm{r}\right)$

En este fragmento se afirma que los poeta-soldados son varones ${ }^{467}$ escogidos por Dios, así como han sido escogidos los mártires que componen sus himnos para alabar al creador. No obstante, hay una serie de aspectos a considerar. En primer lugar, no se menciona al ingenio -a diferencia de lo que ocurre en el Cisne. Más bien, a los "escogidos varones" se les permite tener en un mismo entendimiento "la ciencia de contemplar, y el animo de pelear" - lo que se relaciona con la vida contemplativa y activa del neoaristotelismo.

Por supuesto, dicha "ciencia de contemplar" podría asociarse al ingenio o, al menos, a esa parte que se encarga de buscar la materia poética. En otras palabras, tendría que considerarse la cualidad receptiva del ingenio que he encontrado en las poéticas dialógicas de Pinciano y Carvallo. Sin embargo, descarto tal interpretación porque no hay ningún indicio que justifique dicha relación. Además, aún suponiendo que el ingenio sea para Carrillo parte del entendimiento, este no es de origen divino, puesto que solo se dice que los poetas han sido escogidos por Dios en tanto su entendimiento acoge la parte pasiva de la contemplación y la activa de las armas.

(loc. cit.). En el caso de Carrillo, su teoría continúa basándose eclécticamente en autoridades clásicas y renacentistas, pero la forma en cómo las interpreta le permite transforma el binomio arte-ingenio y distanciarse así de la tradición.

466 Carrillo y Sotomayor vivió el tópico săpüentǐa et fortītūido renacentista, así como lo había hecho en su momento Garcilaso. Sin embargo, a diferencia de este, también se ocupó de teorizar sobre tal aspecto en su poética, en donde incluso las musas son guerreras que con sus lanzas atacan a los indoctos. De tal forma se comprueba lo que Curtius ya había notado sobre las letras y las armas en España (vid. Literatura europea y Edad Media latina, I, p. 256-258).

${ }^{467}$ Sobre este aspecto, no se olvide que para Pinciano el ingenio poético es varonil, lo que pone de manifiesto que la tradición misógina está presente en las poéticas de los Siglos de Oro, aunque matizada de diferentes formas. Así, Pinciano aceptó que hubiese mujeres con esta capacidad varonil - como la poetisa Safo-, mientras que Carrillo pone como

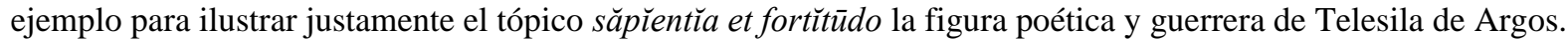


Reitero luego que en este fragmento se trata literalmente de una parte del entendimiento encargada de percibir el mundo circundante, el cual además no es en sí mismo divino. De hecho, este necesita de una "ciencia", o bien un método que no corresponde con el arte de las poéticas dialógicas, sino al de la erudición que "lima", como anoté más arriba (vid. "Capítulo II"). Carrillo empieza entonces a calificar la capacidad que realmente le interesa desarrollar en detrimento del resto: el entendimiento.

Por otra parte, el joven poeta-soldado afirma que los mártires pueden componer sus himnos de alabanza por dos motivos: furor divino o afición. Dicho de otra forma, la creación poética de estos seres bisagra puede deberse a un trance divino o a una motivación personal, a una "propensión, amór,

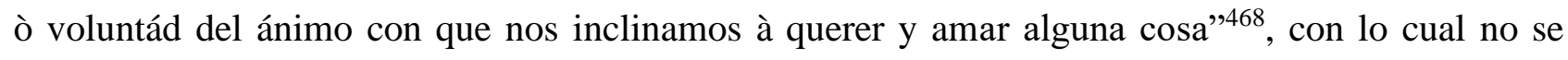
requiere ninguna intervención externa. La manera en cómo se consigue tal afición o cómo esta se materialice en los himnos, no se especifica, pero es claro que para Carrillo las obras de los mártires pueden darse con o sin intervención divina. Esta afirmación reinterpreta entonces también el furor profético para quitarle su papel como única causa eficiente de la creación poética religiosa. En suma, se ofrece otro ejemplo de cómo se circunscriben las funciones del ingenio y del furor, para darle al entendimiento mayor importancia y volverlo la base de la erudición poética.

El "Libro" continúa con una amplĭfícātĭo del tópico săp̌̌entĭa et fortĭtūdo ${ }^{469}$, el cual, a través de una vărīatǐo, se utiliza para justificar lo tardío de la producción poética española, como ya lo había hecho antes Herrera ${ }^{470}$. Para ambos escritores, así como para sus coetáneos, España no tenía las condiciones históricas propicias para la creación poética, debido a las constantes guerras que asolaron la península hasta la Reconquista. Por tal motivo, Carrillo afirma:

Nuestra madre España, despues de auer encubierto las antiguas desgracias, con tan desacostumbradas vitorias al valor delos hombres, acordose de si, ò (por mejor dezir) sus hijos colgando las espadas, tuuieron memoria de ella, atreuieron las plumas a hazer alardes de los ingenios, tan parecida en esto a la antigua madre del valor antiguo, que no se sabe huuiesse poeta en Roma antes de pasada la segunda guerra Punica. ( $M_{1}$ f. 112 r)

${ }^{468}$ Diccionario de la lengua castellana..., s. v. aficion.

${ }^{469}$ Vid. Luis Carrillo y Sotomayor, "Libro de la erudición poética", Obras, Rosa Navarro (ed.), p. 324, n. 7.

${ }^{470}$ La relación entre la Anotaciones y el "Libro" son numerosas. De hecho, el principio inaugural de Herrera es recuperado por Carrillo y llevado a sus últimas consecuencias. Así, sobre el "Soneto I" dice el sevillano: "Pienso, que por ventura no sera mal recebido este mi trabajo delos ombres, que dessean ver enriquecida nuestra lengua con la noticia delas cosas peregrinas a ellas; no porque este necesitada i pobre de erudicion i dotrina; pues la vemos llena i abundante de todos los ornamentos i joyas, que la pueden hazer ilustre i estimada; si no porque atendiendo a cosas mayores los que le pudieron dar gloria i reputación, o no inclinandose ala policía i elegancia destos estudios, la desampararon de todo punto en esta parte" (Obras de Garci Lasso dela con anotaciones Vega de Fernando de Herrera, p. 65). 
El ingenio aparece por primera vez en la poética y funciona tanto como metonimia de poetas, como de las obras creadas bajo su supervisión. Es decir, ofrece su tradicional denotación como capacidad creadora $^{471}$, aunque esta es minimizada.

La apología de la poesía española reafirma un principio presente en los folios inaugurales del "Libro" que advierte sobre una necesidad fundamental para el quehacer poético: "Amigas son d[e]l ocio las Musas" ( $M_{1}$ f. 110r). La guerra, por lo tanto, no permite que estas se manifiesten; es decir, no permite "hazer alardes de los ingenios". Carrillo señala la condición externa y material š̆nĕ quā nōn la capacidad humana no puede desarrollarse plenamente a fin de mostrar una valía equiparable a la gloria obtenida en el campo de batalla: "Eternidad, y valor prometen las Musas"472.

Obsérvese, pues, las características que el ingenio adquiere en el "Libro". En primer lugar, la capacidad nata se relacionada indirectamente con la figura de las Musas ${ }^{473}$, y, en segundo lugar, el carácter divino de las hijas de Zeus le infunde una cualidad igualmente divina, misma que sirve para asegurar la eternidad al poeta y alejarlo del vulgo. Quiero hacer hincapié, empero, en que tal cualidad divina se manifiesta con ayuda del entendimiento, que es el encargado de develar los secretos de las Musas ${ }^{474}$, mismos que Carrillo ilustra en el "Libro". Lo anterior podría representar una contradicción porque si tales secretos pueden ser escritos e incluso enseñados se estaría volviendo comprensible su aspecto divino; es decir, se le retiraría todo aspecto místico, inexplicable e inefable. En parte es así, pero es gracias a que la erudición poética tiene un carácter bivalente: parte de una capacidad divina (ingenio) que puede ser mejorada a partir del esfuerzo humano que se cristaliza en la erudición.

Con esto, Carrillo parece colocar en una balanza la dualidad erudición-ingenio, porque "Amigas son d[e]l ocio las Musas". La divinidad entonces necesita cultivarse durante ese tiempo que ofrece el òtŭum -entendido a la manera clásica. En consecuencia, dicho perfeccionamiento del ingenio depende tan sustancialmente de ese ôtium que su capacidad creadora e innata es insuficiente para la creación poética erudita. Esto no significa que Carrillo siga la línea de Cascales, quien encierra en los

${ }^{471}$ Cito el erudito estudio de Lausberg: el ingenio "es un don natural que no puede ser sustituido ni por el arte (ars) ni por la imitación (imitatio)" porque "es la creatividad o productividad (por ejemplo, la fantasía [...]), la cual necesita ser dirigida" (op. cit., § 1152). Para Carrillo, el ingenio continúa teniendo ingerencia en el proceso creativo, pero lejos de ser sustituido por un ars o por la imitatio -que no dejan de estar presentes- es completamente dominado por el término principal de la poética: la erudición.

${ }^{472}$ A propósito de la fama y eternidad a los que se aspira en el "Libro", Carrillo retoma la larga tradición clásica al respecto, misma que equipara los logros militares con los de la pluma (vid. María Rosa Lida de Malkiel, La idea de la fama en la Edad Media castellana, pp. 15-113 et passim).

${ }^{473}$ Así se evidencia en los versos que traduce Carrillo: "Punica al bellicoso pueblo, y fiero / De Romulo, abladò la dulce Musa" ( $M_{1}$ f. 112r). Por un error de fuente o memoria, en el "Libro" se asegura que estos son de Ennio, cuando en realidad pertenecen a Porcio Licinio como confirma Navarro (vid. Carrillo y Sotomayor, "Libro", op. cit., p. 326, n. $15)$.

${ }^{474}$ Es imprescindible destacar que el entendimiento y el ingenio son capacidades estrechamente relacionadas entre sí, pero las funciones específicas de cada una de ellas -comprender y crear respectivamente- me permite establecer los límites que cada termino tiene sin confundirlas entre sí. Esto no significa que no pueda haber entre ellas una relación cooperativa que ayuda tanto a los teóricos de la época como a los de ahora a racionalizar el complejo proceso creativo. De hecho, es gracias al entendimiento en Carrillo que tal explicación es posible. 
límites del arte al ingenio, sino que a la par del ingenio está latente el perfeccionamiento del poeta con la erudición. De esta forma, el resultado de su trabajo en conjunto es lo que origina la poesía erudita.

Con base en lo anterior, sugiero que además del ingenio, lo divino para el poeta español es la

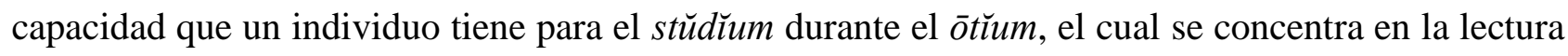
e ̌̌mĭtātı̌o de los clásicos, quienes tienen un papel fundamental en la poética. Esto último se infiere en primera instancia por las divinidades que presiden la creación poética: las Musas. El cuatralbo propone figuras del mundo pagano como guías de los poetas y no del mundo cristiano como la de Cristo, con la que se le asocia al poeta en el Cisne.

A esto se debe aunar que se relacione la situación de España con la de Roma. La comparación de carácter histórico funciona como prŏbāť̌o de gěnŭs artificiale por inducción (conlātı̌o) para la argūmentātı̌o de Carrillo, lo cual es una constante en el "Libro". Para el erudito poeta, el mundo clásico es una prŏbātǐo por autoritas o por inducción -como ya observé más arriba (vid. "Capítulo II"). La justificación de la erudición poética posee innegablemente una base clásica, como se deja en claro con las frecuentes citas de clásicos y modernos, los cuales, a su vez, recuperan el bagaje grecolatino.

La relación erudición-ingenio se reafirma con la enunciación del primer paladín de la săpı̌entĭa et fortitutdo: Garcilaso. En este, el oficio militar se compaginó al poético con una obra que "excedio las esperanças de los Italianos, en cuanto a nuestra nacion, y a los nuestros abriò camino, para presumir de tan dichosa osadia frutos tan colmados como los suyos" ( $M_{1}$ f. 112v). Garcilaso es para Carrillo la figura parteaguas de la poesía nacional, que logró conjuntar la espada y la pluma ${ }^{475}$, y superar así a los modelos italianos. A partir de él:

Ha ydo con tan notable excesso creciendo este loable estudio despues acà, y ha tenido nuestra España sujetos, que à auer acompañado con diligencia, y estudio las fuerças del ingenio, tuuiera Italia acerca de nosotros menos ocasión de desprecio, y mas que temer a los lugares de sus Petrarchas, y Tasos. Esto con la experiencia del tiempo, y con la noticia, que del se adquiere, con la conocida ventaja q[ue] hasta ahora (respeto de las cosas antiguas) se ha tratado, parece ofrecia la esperança las manos à darnoslas presto en exercicios de ingenio, en el mismo lugar que las vitoriosas hazañas de nuestra nacion ha puesto el suyo con sus vanderas, y sus armas: bien necessarias pues son estas plumas a la eternidad de tan famosos arneses, y celadas. ( $M_{l}$ fols. $112 \mathrm{v}-113 \mathrm{r}$ )

\footnotetext{
${ }^{475}$ El poeta militar representa así su modelo nacional: "El fue pues el primero de nuestra profesion Militar, que illustrò con sus escritos a nuestra España" $\left(M_{l}\right.$ f. $\left.112 \mathrm{v}\right)$. Con esto, no solo se ofrece un testimonio más de la importancia de Garcilaso en el quehacer poético español, sino que también se indica la tradición a la cual pertenece Carrillo, caracterizada por el furor divino y de carácter formal-hedonista.
} 
En esta segunda apología de la poesía nacional -aquí con respecto a la tradición italiana ${ }^{476}-$, se ahonda en el tipo de camino poético que abrió Garcilaso. Carrillo señala aquí otros aspectos con los cuales el ingenio ofrece "frutos tan colmados como los suyos": "diligencia, y estudio". Me parece que tales hábitos no constituyen propiamente un arte, puesto que no se mencionan los preceptos y las reglas poéticas. Implican por tanto una disciplina, que alude sin duda a la erudición poética y el conocimiento que esa porta consigo. En consecuencia, considero factible que el "Libro" haga eco de las teorías platónicas expuestas en la República y el Sofista-especialmente el segundo-con respecto a la imaginativa, la poesía y la imitación.

Tal y como explica Víctor Fernández-Corrugedo, Platón contrasta "la imitación de lo que se

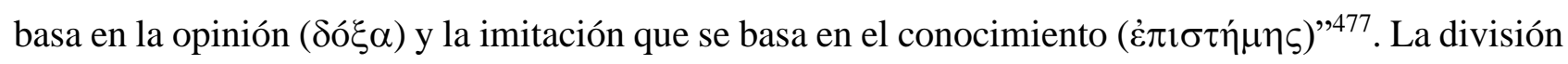
alude a un problema epistemológico que justifica la expulsión de los poetas de la República ideal de Platón, al negar a la poesía toda posibilidad didáctica (dŏcēre), pues la constriñe al deleite (dēlectāre). Para Carrillo no existe tal problema porque su finalidad es justificar la poesía erudita, difícil para los indoctos abandonados por unas Musas que requieren del ōtı̆um para su manifestación. Pese a esto, es evidente que el ingenio carrillesco debe aspirar al segundo tipo de imitación; es decir, sus resultados se perfeccionan con diligencia y stŭdĭum, para procurar una imitación docta o, más aún, erudita.

De tal guisa, se conserva la cualidad mística de la poesía, así como su elitismo y su carácter privilegiado en la sociedad. Sin embargo, en el "Libro" -a diferencia de las poéticas dialógicas analizadas- no se justifica la poesía por su ūtǔlitās. No porque la poesía condujese a conclusiones "falsas" debido a la imitación de fantasmas - como hizo Platón ${ }^{478}$-, sino porque solo puede ser entendida por los que poseen la erudición poética. A Carrillo no le preocupa si el vulgo es educado o no, al contrario, prefiere la incomprensión de este. Su función social es pues inexistente y no cumple con el dŏcēre; aunque tampoco con el dēlectāre popular -por llamarlo de alguna forma. La poesía erudita obedece más bien a la develación de la realidad con ayuda del entendimiento (contemplación), del ingenio (creación) y del stŭdı̆um, lo que deleita al poeta y a sus iguales.

Ahora bien, si existe stŭd̆̌um y diligencia, la capacidad natural del ingenio español se equipara y supera al italiano -tópico al que recurre también Cascales (vid. supra). Para esta parte de la argūmentātı̌o, Carrillo recurre a pruebas lógicas y a signa específicos: los “exercicios de ingenio"; es

${ }^{476}$ La defensa de la poesía española estaba motivada principalmente tanto por lo tardío de su aparición como por la lengua que utilizaba. Es decir, era también una defensa de la lengua castellana o vulgar, problema al que se habían enfrentado también otras tradiciones literarias como la italiana y francesa. En el caso de España, esta defensa alcanzó su punto cúlmine durante el siglo XVI y principios del XVII, aunque ya desde el siglo XV se encuentran apologías como la de Antonio de Lebrija en su Gramática (vid. José Francisco Pastor, "Introducción” a Las apologías de la lengua castellana en el siglo de oro, J. F. Pastor ed., pp. XXV-XXX). Cabe mencionar que esta defensa es un punto más de convergencia entre Herrera y Carrillo, y sobre el que regresa el cuatralbo al final de su discurso (vid. $M_{l}$ fols. 138v-139r).

${ }^{477}$ Op. cit., p. 89.

${ }^{478}$ Vid. id., pp. 75-97, passim. 
decir, el resultado del ingenio. Hay que enfátizar que se les llama "exercicios", lo que implica nuevamente la constancia, pero también la práctica y la dedicación de un determinado oficio, la poesía $^{479}$. Se pone en evidencia cómo Carrillo se mueve entre el plano de la poesía como don divino y como práctica racional, practicable y perfectible.

En la propuesta del "Libro", la dualidad arte-ingenio ya no es suficiente para explicar el fenómeno poético. De aquí la necesidad de la formulación de la erudición poética -la poética de la erudición-, en donde el ingenio tiene un papel relevante, aunque se compagina -mas no se subordinacon la disciplina y el stŭdı̆um. Cabe agregar que, hasta el momento, el "Libro" no ha establecido algún tipo de graduación con respecto a los productos del ingenio. Más bien, parece que una creación es digna de un poeta docto cuando aquella siga el camino de Garcilaso, el de la erudición poética.

La dualidad divina y racional del poeta ideal de Carrillo es aludida nuevamente, pero esta vez bajo principios platónicos que involucran la teoría de los furores y en la que se basa la distinción entre versificadores y poetas. El ánimo de los últimos es

encendido en ciencia, y calor de diuinas Musas, guiassen por qualquiera diferencia de virtud, ò acontecimie[n]to, tomaron por laurel desta gloria el dichosissimo, y bonissimo amparo de las Musas: mal por cierto, si ellos, ò sus Musas, son descubridores de las cosas escondidas, las entenderan los que à penas conocen letras. $\left(M_{l}\right.$ f. $\left.114 \mathrm{v}\right)$

Los poetas son "descubridores" de los misterios escondidos en la realidad y negados a los indoctos. Esto lo consiguen gracias a la inflamación divina de la Musas, pero también y antes de esta, al resultado de la ciencia, obtenida sin duda a través del stŭdŭum de las letras -justo las que desconoce el vulgo.

En el fragmento observo que no está presente el ingenio, pero sí las cualidades del furor, mismas que afectan al ánimo por el calor tanto de la ciencia (producto de la diligencia/motivo racional) como de la Musas (origen divino/motivo irracional) ${ }^{480}$. No obstante la carencia ăd litteram del término que preocupa a la presente investigación, es innegable que el sentido que engloba esta explicación alude directamente al proceso de la inventǐo poética, que hasta este momento había sido únicamente jurisdicción del ingenio. Además, Carrillo asocia al ánimo la inflamación que le permite elevarse a las "cosas escondidas"; un proceso que las poéticas dialógicas habían ligado exclusivamente a la capacidad inventiva por excelencia ${ }^{481}$.

${ }^{479}$ En el Diccionario de la lengua castellana... se lee en la $s . v$. exercicio: "El acto de exercitarse en alguna cosa: como en las armas, en las letras, en la Pintura, etc."; y en $s . v$. exercitarse: "Vale emplearse, dedicarse al exercicio y empleo de algún ministerio y oficio". En el "Libro", por tanto, la poesía es un oficio independiente que necesita una determinada práctica, justo lo que se describe en los primeros folios.

${ }^{480}$ Considero notable que el doble origen de la inflamación poética ya estaba sugerido en los mártires que creaban sus himnos de alabanza con ayuda del furor divino o de la afición.

${ }^{481}$ Esta parte de la argūmentātǐo no deja de depender de la tradición clásica, aunque con un importante cambio. Según la retórica de Quintaliano, glosada por Henrich Lausberg, el “orador, antes de intentar sumergir al público en la situación del testigo ocular, debe poner, por decirlo así, al rojo vivo su fantasía creadora” (op. cit., § 811). Este precepto que busca obtener eficazmente la captātǐo benevolentiae del público comporta la inflamación, pero de la fantasía, una 
Entonces, es un hecho que este proceso de "hallazgo" no implica al ingenio, primero porque se menciona al ánimo en su lugar y luego porque es el entendimiento la capacidad natural humana que posee la "ciencia de contemplar" ${ }^{482}$. Así lo reafirma con una prŏbāť̌o por auctoritas de Boecio: "Alas tengo ligeras, que del cielo / Bolaron lo mas alto, y mas diuino, / Las que el entendimiento presto viste, / Desprecia aborreciendo el baxo suelo" ( $M_{1}$ f. 117r). Carrillo se vale de la misma alegoría usada por Carvallo en el Cisne, pero no es el ingenio quien se eleva con alas ligeras hacia lo divino, sino el entendimiento.

Durante el "Capítulo II" de la investigación, establecí que la única capacidad divina per sé en el "Libro" es la razón y, como parte de esta, el entendimiento puede acercarse a ella. Con base en esto, se puede concluir la base racionalista que el "Libro" posee. El entendimiento es la capacidad racional encargada de encontrar las "cosas escondidas", lo que no impide que se le reconozca un carácter divino de tipo irracional. Reitero que en la poética discursiva hay un juego entre lo divino y lo racional, entre la inflamación y el stŭd̆̌um asiduo tan complejo e intrincado que se pierde toda dualidad posible entre arte e ingenio. El arte -conjunto de normas y preceptos- es sustituido por la erudición y el ingenio es descargado de funciones imprescindibles como el "hallazgo" de la causa material, que Pinciano, por ejemplo, sí le reconoce. Todo esto en obediencia a la creación de una poética de la erudición que justifica la existencia de la poesía erudita, cuya causa final no es el dŏcēre ni el dēlectāre del vulgo ${ }^{483}$, sino penetrar con el entendimiento el saber oculto de las Musas.

La siguiente mención del ingenio se encuentra inmersa en la extensa glosa que el poeta cuatralbo hace de una cita de Aristóteles -cuya fuente es imprecisa, como he referido más arriba (vid. “Capítulo II”)-_ ${ }^{484}$, que le permite reflexionar sobre la fama que el poeta puede obtener con sus obras. Asimismo, a través de una commŏrātǐo, la poesía erudita es defendida nuevamente del pernicioso

capacidad no racional e inventiva. Debido a que en el "Libro" no es importante ni la captāťo benevolentiae ni el deleite del público, el proceso de poner "al rojo vivo" se traslada de la fantasía al entendimiento. Por ello, se racionaliza un proceso originalmente irracional.

${ }^{482}$ De hecho, el ánimo podría asociarse al entendimiento, puesto que es el "alma, el espiritu que hace discurrir y moverse los animáles" (Diccionario de la lengua castellana ..., s. v. animo). En consecuencia, lo que se está inflamando es una capacidad racional del ser humano, confirmando que para Carrillo es la parte raciona la encargada de penetrar en los asuntos elevados.

${ }^{483} \mathrm{El}$ ataque al vulgo es constante, pero el punto álgido se localiza en la distinción entre el orador y el poeta: “el Orador cuelga de la aprouacion del pueblo, sus buenas, ò malas razones, son los buenos, ò malos discursos [...]. De $s i$ el Poeta se cuelga, y se es el oye[n]te, el es el juez en su misma causa" ( $M_{l}$ fols. 116r-v). Vilanova, a propósito, comenta: "No puede darse una afirmación más tajante de independencia artística y de soberbia intelectual que la que encierran las palabras de Carrillo, verdadera profesión de un arte para minorías" (op. cit., p. 645). Las palabras del estudioso no pueden ser más certeras sobre la opinión que tiene el poeta sobre la elite intelectual poética y su independencia del juicio del público. Sin lugar a duda, es una de las afirmaciones que más deja en claro la finalidad que la poesía tiene para Carrillo, una que se aleja de los principios renacentistas.

484 Transcribo nuevamente la traducción hecha por Carrillo para facilitar la comprensión de las subsecuentes menciones del ingenio: "Vnos animales, por ciertos indicios, y señales, aprendiendo de la naturaleza, discurriendo otros con socorro de la razon, lo que es prouable con el entendimiento alcançado" ( $M_{l}$ f. $114 \mathrm{r}$ ). Nótese que una vez más se le da al entendimiento un papel privilegiado para la creación de conocimiento, por lo que sigue siendo la capacidad rectora en esta poética de la erudición. 
juicio de los indoctos y se reafirma que el vuelo de los poetas los aleja de la envidia. La "naturaleza de bolar participa mucho de Dios, quando no sea mas que con ellas hazerse essentos de la embidia" $\left(M_{1} \text { f. } 120 \mathrm{r}\right)^{485}$. Dentro de las prŏbātĭones para este argumente aparece el epitafio que Séneca creó para su propia tumba, cuyo tópico nōn omnis mŏrĭar evidencia la eternidad y la fama obtenida con sus obras ${ }^{486}$.

Asimismo, es glosada por el poeta:

Y por cerrar esta parte con la opinion de nuestro Ciudadano Seneca, en esto como en todo (à pesar de embidiosos, y menores de su ingenio) sola ay en las cosas humanas esta obra, à quie[n] ni ofende tempestad, ni consume vejez ${ }^{487}$. Esta fue la opinion que tuuieron de $s i$ trata[n]do de las letras, con la doctrina que vemos, estos los cimientos en que fundaron tan firmes esperanças contra el tiempo, los efetos dize nuestra edad, haciendo profecias sus palabras, opinion adquirieron con los buenos versos, tratandolos con las buenas letras, ellos lo pronosticaron, la fama no se les puede negar, ni à mi este argumento la verdad de qualquier causa eficiente, por si su certidumbre ha de constar de sus efectos. ( $M_{1}$ f. 121r)

Nótese que el ingenio no ha sido tipificado por Carrillo a lo largo de su disputa; es decir, no se ha hablado de un ingenio poético -como tampoco se le ha tipificado al entendimiento-, pero en este caso se cuantifica, porque hay quienes tienen más ingenio -Seneca- que otros -los "embidiosos". Se contrasta lo expresado por Pinciano en la Philosophia, donde el ingenio es una capacidad común a todos los seres humanos, pero de cuyo desarrollo y tipo dependen las obras de cada individuo. La justificación de la cantidad de ingenio depende siempre de la divinidad que caracteriza al poeta, misma que le permite hacer profecías y romper las adversidades temporales. Esto último, no obstante, no solo se debe a su divinidad o ingenio, porque la poética de la erudición siempre va acompañada de la doctrina que ayuda a la creación de "buenos versos" y "buenas letras": vehículo de la fama poética, la cual no se puede negar a quien bien práctica esta poética.

Para Carrillo, la fama no puede ser negada a los poetas porque la causa eficiente de esta no permite que sea de otra forma, pues “su certidumbre ha de constar de sus efectos”. Ahora bien, ¿a qué se refiere con causa eficiente? Al estilo, a la causa formal de la poesía como afirma a continuación: "Pues assi es, que estos (mediante el modo de escriuir vsado dellos) alcançaron el fin vltimo de los Poetas, que es la fama" (loc. cit.). En breve, la causa formal de la poesía -“el modo de escriuir” o

485 Sobre esta función del ingenio Carrilllo volverá a hacer énfasis casi al final de su poética: “Ciceron (no es aqueste lugar de sus alabanças) no se escapò, ni pudieron las alas de su ingenio vsurpalle de la vista de sus contrarios, al qual se atreuian à reprehender, como hinchado y Assiano: porque tan clara fuerça de la eloquencia no pueden sufrir" ( $M_{l}$ f. 133v). El estilo limado de Cicerón es reprobado por los indoctos que no han estudiado lo suficiente para comprenderlo y, en este caso, su ingenio no ha sido capaz de elevarlo lo suficiente. Tal hecho no se reprueba en ningún momento por Carrillo, ya que su atención está en destacar la responsabilidad que el público tiene para entender las enseñanzas que los doctos les transmiten en prosa o verso. De esto se deduce que la capacidad de vuelo del ingenio no tiene que ser perfecta para ser considera un poeta docto.

${ }^{486}$ El epitafio traducido por Carvallo reza: "Nadie mi entierro con llantos / Honre, porque buelo viuo / Por lenguas de varones" ( $M_{l}$ f. 114r).

${ }^{487}$ Desde "sola ay" hasta "vejez" es otra cita de Seneca de su Ad Polybium de consolatione (vid. Carrillo y Sotomayor, "Libro", op. cit., p. 345, n. 84). 
bien el estilo- se convierte en la causa eficiente de la fama, que es la causa final del poeta, o bien, del docto escogido por las Musas. Por supuesto, la fama es la meta del poeta, mas no de la poesía, puesto que su causa formal no podría ser al mismo tiempo su causa eficiente. No obstante, no considero pertinente afirmar que dicha causa en la poesía siga siendo el ingenio. De hacerlo, tomaría en cuenta únicamente la tradición clásica que, aún con sus toques personales, Carrillo coloca como prŏbātǐone. Hasta el momento, la definición del ingenio es bastante limitada en la erudición poética, ya que únicamente se ha especificado que requiere de la ayuda del stŭd̆̌um y la disciplina, y su cercanía a la divinidad.

Pese a la falta de atención que el ingenio tiene en el "Libro", el cuatralbo la concibe como una característica evaluadora de las "coronas de los poetas", es decir de los versos creados por los doctos poetas. Referí en el "Capítulo II" la defensa a favor de Lucrecio como poeta. Recuérdese que el principal argumento a favor de esto es que la obra se produce con disciplina y stŭdŭum. La apología que se convierte en un encomio a la dificultad poética no solo se realiza a causa de los juicios negativos de los indoctos, sino también de aquellos que discurren agudamente y cuyos ingenios consideran que la causa material del poema latino es poco adecuada y atrevida.

Diran agudamente algunos, o inferiran (quie[n] lo duda?) del error de la opinion, quan poco acertado le fue al Poeta, ocupar sus versos en tan graue materia: valedores tuuo esta opinion, y no pocos antiguamente, baste en nombre de los demas Plinio Filosofo, lib. 2. capit. 7. y quando no lo fuera, escusa el desacierto la dificultad de la materia, califica el ingenio atreuimiento tan alto. $\left(M_{1} \mathrm{f} .123 \mathrm{v}\right)$

Mientras el entendimiento agudo deduce de la opinión que la causa material es demasiado grave para los versos de Lucrecio, el ingenio considera que es un atrevimiento. Este, a diferencia del "Diran agudamente", no se puede adjudicar a Plinio, pero tal vez sí se refiera a otros "antiguos" y de ahí que se le continúe tratando con el debido respeto que un docto merece dentro la poética de la erudición. Además, Carrillo comparte la opinión sobre los versos comentados, que, por negar a la providencia, demostraban cómo "Notable atreuimiento le dio el arte" $\left(M_{l} \text { f. } 123 \mathrm{r}\right)^{488}$. Sin embargo, en el caso del cuatralbo no es un juicio de censura, sino de admiración por aquello que se consigue por medio del artificio y del stŭdŭum.

Esta consideración del ingenio como juez es la primera que se menciona a lo largo del "Libro", aunque en otros momentos Carrillo da tal labor al entendimiento, al cual se le adjetiva como agudo (vid. "Capítulo II"). En el caso del ingenio, empero, no puede decirse que sea agudo-lo que implicaría que fuese "limado" con la erudición- ni tampoco que posea otro tipo de cualidades. Pese a esto, no hay que olvidar que en esta intrincada poética apologética y encomiástica el subtítulo de la marginalia

${ }^{488}$ Para precisar, el arte del "Libro" son los preceptos de los clásicos en tanto son fuentes de donde se obtiene principalmente erudición, puesto que así usa Lucrecio a Epicuro; aunque también engloba aspectos del arte más tradicionales, porque son modelos de ̌̌mütātı̆o su agudeza, elocuciones e imitaciones (vid. "Capítulo II"). 
del folio 117r reza "Doctrina para el juizio". Aquí se hace hincapié en la importancia de la educación que debe tener quien juzga un determinado arte y cómo estos dos aspectos deben obedecer la misma doctrina.

En la erudición poética quien juzgue la obra de otro debe ser capaz de hacer por su propia cuenta una obra de calidad y, en caso de no ser capaz de esto, al menos sí debe haber estudiado con la misma dedicación que el creador, de lo contrario no es digno ni siquiera de apreciar la obra erudita $^{489}$. El ingenio puede juzgar la poesía de Lucrecio como atrevida siempre y cuando quien lo diga posea la doctrina necesaria para hacerlo, aunque el juicio que este hace sea contrario al encomio que merece la poesía erudita. La erudición permea cada elemento de esta poética, incluyendo el ingenio, cuyas funciones siguen siendo apenas aludidas.

Ahora bien, la siguiente mención del ingenio está inserta en la prescripción de las "buenas letras" y recupera el matiz metonímico descrito para los "exercicios de ingenio". Carrillo glosa un verso de la Eneida (vid. "Capítulo 2") para demostrar el estudio que debe poseer el lector del autor latino:

no con facilidad se dexaran conocer estas cosas de los no muy verdaderos sucessores de las buenas letras, y ellas menos recoger $\mathrm{a}[\mathrm{n}]$ debaxo de su amparo à aquellos, $\mathrm{q}$ [ue] en desuelos no huuieren calificado las inte[n]ciones de su ingenio co[n] ellas. Huuo entre aq[ue]lla copia de illustrissimos ingenios en Roma vno, milagro de los demas, ò quando no, de los mas excelentes por lo menos, fue aqueste Craso, q[ue] bien conocio el lugar q[ue] merecia, acerca del la opinio[n] de los no muy doctos. ( $M_{1}$ f. 127r)

En el "Libro" las "buenas letras" no se determinan por el dŏcēre ět dēlectāre, sino que están vinculadas, como el resto de los elementos de la poética, a la erudición y al trabajo que implica.

Por lo tanto, sus herederos legítimos deben pasar por una prueba fundamental: develar con el stǔdǐum ("las buenas letras") las intenciones del ingenio. Una vez más, no es el ingenio el que es "afilado" o educado de alguna forma con la erudición o las "buenas letras", sino que estas ayudan a descifrarlo. El ingenio adquiere en consecuencia un cariz equiparable a los misterios que resguardan las Musas. Asimismo, se aproxima a la teoría huartiana que presupone un método para identificar el tipo de ingenio que corresponde a cada actividad humana.

Con base en esto, comprendo que existan mejores ingenios que otros, e incluso los haya ilustrísimos, como el de Lucio L. Crasso, "el Orador", quien prescribe tanto el ars rhetorica como el conocimiento de la doctrina filosófica -motivo principal por el cual es admirado por Carrillo ${ }^{490}$.

${ }^{489}$ En el "Libro" se lee textualmente: "En buena Filosofia, el impedido que no corre, puede (quitado el estoruo) correr: censurarà como los demas al Poeta: el que no lo haze, si estudiare, si aprendiere. [...] El çapatero no fuera de su trabajo aun de los grandes hombres errores aueriguados se reconocen con desconfiança, y se reprehe[n]den con temor. [...] Mal se atreuera el indocto à mirar las obras del q[ue] no lo es" $\left(M_{l}\right.$ f. $\left.117 \mathrm{v}\right)$.

${ }^{490}$ En Sobre el orador (1, 7, 24-34), Cicerón, en boca de Escévola, hace el símil de la conversación que este tiene con Craso sobre la importancia de la èlŏcūtĭo oratoria, con el diálogo socrático representado en el Fedro, en donde justamente se conjuga en la retórica el arte y la dialéctica. 
Además, el latino presupone que el buen orador es capaz de conocer y ganarse la buena opinión de los indoctos por medio de las "palabras" -en términos carrillescos. Sin embargo, esta habilidad parece estar más relacionada con la agudeza como ya comenté (vid. "Capítulo 2"). En consecuencia, me parece que lo más relevante a propósito del ingenio en este fragmento, además de su susceptibilidad a ser calificado como ilustre o no, es cómo su naturaleza de forma indirecta se acerca a lo divino, aspecto ya presente en otras menciones y que se reafirma más adelante.

A partir de ahora, el "Libro" se centra en su defensa de la èlŏcūtı̆o diffícŭlis y comienza con la descripción del "Estilo de Poetas" (M $M_{l}$ f. 128r i.m.), del que dice: "me parece los Poetas ha[n] hablado en le[n]gua agena, pero en la comunicacio[n] de las mismas plazas, en el ordinario concurso dellas, difere[n]ciauan aquellos antiguos varones en la manera del estilo la suerte de la calidad, y del ingenio de los q[ue] posseìa[n] ambas à dos cosas" (loc. cit.). A la afirmación hecha por Cicerón sobre el peculiar hablar de los poetas ${ }^{491}$, Carrillo agrega que los “antiguos varones" observaban de esta forma cómo los poetas se alejaban del habla del vulgo en las plazas y que a partir de esta distinción identificaban tanto la calidad de su ēlŏcūtı̆o como de su ingenio. En otras palabras, el ingenio ayuda a la creación de la êlŏcūtǐo poética y se configura como una capacidad determinante para diferenciar al poeta del indocto desprotegido de las Musas.

En menciones anteriores he aludido a la posible capacidad divina del ingenio, aunque observé también que el acercamiento del poeta a la divinidad obedece más a una cuestión racional, puesto que es a través de la erudición que uno se convierte en un docto y próximo a las Musas. Por lo tanto, con la poética de la erudición el poeta se gana el favor de estas y por ello su élŏcūť̌o no puede ser criticada por los indoctos ${ }^{492}$. Asimismo, es siempre la erudición la que justifica las licencias elocutivas (figurae elocutionis), puesto que la misma materia que trata -los secretos de las Musas- exige la separación del habla del poeta de aquella del vulgo.

En esta parte de la disputa y como parte de sus prŏbātǐones por auctoritas (citas), Carrillo recurre al "Principe del arte" ( $M_{l}$ f. 128r): Horacio. Los versos $42-44$ de su sátira IV del libro ${ }^{493}$ aluden a la distancia existente entre su estilo - propio de la sátira- y el del "del docto Poeta" $\left(M_{l} \mathrm{f}\right.$. 129r): "Piensa aquel ser Poeta, cuyo ingenio / Diuino, y boca, grandes cosas suene, / Y a este de tanto nombre des la gloria" ( $M_{1}$ f. $\left.129 \mathrm{v}\right)$. Carrillo agrega un signo de interrogación al final de la cita ${ }^{494}$ como parte de su argūmentātı̌o, debido a que realiza una serie de preguntas retóricas, a las que

${ }^{491}$ Como bien señala Rosa Navarro, desde "me parece" hasta "le[n]gua agena" es una cita de Cicerón, Sobre el orador, 2, 14, 61 (vid. L. Carrillo y Sotomayor, "Libro de la erudición poética”, op. cit., p. 358, n. 129).

${ }^{492}$ Vid. $M_{1}$ fols. $128 \mathrm{r}-\mathrm{v}$.

${ }^{493}$ Vid. L. Carrillo y Sotomayor, "Libro", op. cit., p. 360-361, notas 138-139.

${ }^{494}$ En su edición, Rosa Navarro, siguiendo el texto original latino, quita el signo de interrogación final que tanto $M_{l}$ como $M_{2}$ tienen, eliminando la forma en la que Carrillo se apropia de sus fuentes tanto clásicas como modernas (vid. id., p. 361). 
pertenecen los versos del poeta latino. Asimismo, a este lo considera protegido de las Musas y demerita cualquier censura que se le haga a su poesía por haber escrito en un estilo inferior al esperado.

Como indica García Berrio, "Carrillo de Sotomayor [sic], precursor y pregonero anticipado de la lírica culterana, no dudaba en proclamar a Horacio paladín y animador sempiterno de una poesía difícil, escogida y doblada en tantos repliegues hedonistas, como los que él preconizaba" ${ }^{495}$. Por esto, lo llama "Principe del arte"496, peculiar apelativo para una poética que tan poco ha insistido en el ars en aras de la erudición. Me parece oportuno también observar que, con la cita de Horacio, se le asigna por primera vez el apelativo de divino al ingenio, lo cual debe ser interpretado en su justa medida, puesto que será la única vez que se le considere de esta forma y la mención se encuentra dentro de una cita. Sin embargo, las prǒbātǐones del "Libro" no solo ahondan en la argūmentāť̌o, sino que exponen el pensamiento del joven poeta español, por lo que considero que esta divinización del ingenio puede interpretarse en consecuencia.

En otras palabras, considero el carácter del poeta divinizado y racional de la poética, en quien el ingenio puede ser una capacidad creadora ilustrísima, para concluir que el ingenio divino de Horacio-Carrillo es una capacidad que ayuda a separar al poeta del vulgo. No obstante, esto no es determinante, puesto que solo el entendimiento agudo puede penetrar en las intenciones de dicho ingenio. Por lo tanto, esta capacidad, sin la erudición, sin la agudeza que esta proporciona al entendimiento, no es suficiente.

En la novena aparición del ingenio, se continúa la referencia indirecta a su divinidad, pero la importancia recae en su capacidad creadora. Esta aparece una vez que se ha hecho la distinción entre la dificultad y la oscuridad, prescribiendo a la primera sobre la segunda (vid. "Capítulo segundo"). Y para su argūmentātı̌o recurre a la autoridad de Homero, principalmente a los honores que ganó con su obra por la erudición de la que hace gala. El encomio de Carrillo afirma:

solo este vno por todos es: si en los escritos que tenemos de los Iurisconsultos largame[n]te, como lo pedia la sciencia del Derecho, y se escriuiera de aquellas cosas bonissimas, derecho diuino, leyes publicas, maneras de gouierno en sus leyes, que mucho de ordinario ser en su boca Homero, si toda la diuina obra està llena destas cosas? pero tanto huuo de aprender de aq[ue]l fertilissimo ingenio, que si ocupados en aquellas cosas solo los Iurisconsultos, alli tambien hallanssen à Homero, en contrarios parentescos, derecho de sangre, donaciones, delitos, propiedad de palabras. $\left(M_{l}\right.$ f. $\left.132 \mathrm{v}\right)$

Para el poeta, Homero es un fertilísimo ingenio en cuya divina obra se puede encontrar el material suficiente para hacer todo tipo de leyes civiles y penales. Homero, "Principe en $s u$ genero" $\left(M_{l} \mathrm{f}\right.$.

${ }^{495}$ Formación de la teoría literaria. 2, p. 183.

${ }^{496}$ Con respecto a esto, me parece más pertinente interpretar este "arte" como ars, a diferencia de la interpretación que da Rosa Navarro, refiriéndose a la poética de Horacio: Arte (vid. L. Carrillo y Sotomayor, "Libro", op. cit., p. 360). 
133r), es el ápice del docto poeta en el "Libro", aquel al que llama "bonissimo" ( $M_{l}$ f. 132v): poseedor de "buenas letras", creador de "buenos versos" ( $M_{1}$ f. 133r).

En cierta medida -y sin que Carrillo haga énfasis a propósito- se recupera el dŏcēre de la poesía y su ütĭlitās para la República, justificando su existencia social. Esto, por supuesto, es únicamente gracias al saber enciclopédico presente en una obra considerada divina por la erudición que guarda. Esta última se ensalza en todo momento en las páginas del "Libro", pero no deja de ser significativo que en donde hay un agudo entendimiento o un "docto, lleno de todo genero de arte, y ciencia" ( $M_{1}$ f. $\left.132 \mathrm{v}\right)$, existe un ilustrísimo o fertilísimo ingenio. Dicha capacidad creadora no es "limada" directamente por el stŭd̆̌um y, por ende, se muestra como la justificación natural de la superioridad del poeta ante el vulgo.

A lo largo de los folios de la poética discursiva no hay ninguna indicación sobre cómo funciona el ingenio para Carrillo, lo que no niega su función creadora. Esto no lo interpreto únicamente por el adjetivo con el que previamente se le calificó, sino también porque las figuras que son creadas con tal capacidad son llamadas ingeniosas, como ocurre con las traslaciones:

Quie[n] mal lo tuuiere entendido, ò por natural falta, ò por su demasiado descuydo entenderà la fuerça de una traslacion, cuyo juicio, como auemos visto, se le niega al oydo. Mal podrà vestirse tan ingeniosa gala entendimiento acostumbrado à tan barbara desnudez, apoderada de tantos, y defendida, demasiada cosa es, quien lo duda? ( $M_{l}$ f. $\left.134 \mathrm{v}\right)$

Las traslaciones son galas del estilo que pertenecen a los "exercicios de ingenio" y cuya comprensión está sujeta a una cuestión natural o de estudio. Es evidente que el segundo aspecto se refiere al entendimiento - al que claramente se alude-, mientras que esa "natural falta" podría muy bien implicar la falta de un ilustrísimo y fertilísimo ingenio.

Esto ayuda a entender por qué no hay una teorización como tal del ingenio en la poética de la erudición, puesto que está más allá de sus principios, al ser una capacidad que todos poseen, pero en algunos es ilustrísimo o fertilísimo. Tal hecho no detiene el camino poético iniciado por Garcilaso, ya que la poesía erudita depende del esfuerzo de cada individuo, de su stŭdŭum e ı̌mĭtâť̌o de los antiguos. Expresado de otra forma, el poeta docto -con un ingenio superior o no- se gana el favor de las Musas y se diviniza a sí mismo con la erudición poética.

Carrillo y Somayor supera el binomio clásico arte-ingenio, lo que no le niega su importancia al primero, ni tampoco la función creadora al segundo. Además, como comenté, existe la posibilidad de que el ingenio sea -por decirlo en términos retóricos- una prŏbātĭo genus inartificale. Esto es, una prueba en su argūmentātı̌o que sostiene la superioridad del poeta sobre el vulgo, sin que sea esta definitiva o que se pueda desarrollar puesto que su causa es natural y es más que conocida su importancia en el fenómeno poético. 
Con base en lo anterior, me parece que de aquellos individuos que posean un ingenio ilustrísimo o fertilísimo depende que la elite intelectual se mantenga. Asevera Carrillo:

Injusta cosa me parecio personas ser, $\mathrm{q}[\mathrm{ue}]$ mereciero[n] oyr de aq[ue]l milagro de la antigüedad, Plato[n] en su lysis: Vel de amicitia [...], entregados à las manos d[e]l vulgo, y $\mathrm{ta}[\mathrm{n}]$ natural (descuydo notable $\mathrm{d}[\mathrm{e}]$ los buenos ingenios) en ellos ya esta juridicio[n], q[ue] ha sido menester ande[n] d[e] por medio las opiniones de ta[n] graues autores, lo efectos, ò frutos de ta[n] cuidadosos estudios, como los suyos. ( $M_{1}$ fols. $137 \mathrm{r}-138 \mathrm{v}$ )

El ingenio se aúna a los “cuidadosos estudios” y crea frutos que no deben ser aprovechados por todos, precisamente porque no todos poseen ni la buena disposición natural (ingenio), ni la erudición para aprovecharlos como es debido, lo cual es una injusticia para el joven poeta español. Es relevante mencionar que en este fragmento los buenos ingenios son los encargados de evitar que el conocimiento de pocos llegue al vulgo. Parece que el ingenio es el guardián del saber, aunque en este caso se les reprocha no haber cumplido con tal tarea de forma adecuada, lo cual, por supuesto, no afecta de ninguna forma los frutos de la erudición. Su fallo - permitir que el vulgo se acerque a su “exercicios"- no interfiere con la generación del saber, ni la calidad de este.

Para concluir, observo que en la poesía erudita de Carrillo el ingenio tiene una naturaleza divina y tiene una capacidad creadora que debe ser compaginada con el stŭdı̆um de las auctoritates clásicas. Gracias a esto, es la capacidad natural que distingue al poeta del vulgo, siempre y cuando esté bien dispuesta, sea en otras palabras ilustrísima y fecundísima. Además, debido a que este tipo de poesía representa la edad adulta del fenómeno poético, la importancia que el ingenio tiene en su creación es menor que la del entendimiento agudo y que, por supuesto, la erudición. Por lo tanto, mientras la agudeza carrillesca ya anuncia la nueva poesía española y la teoría de Gracián, su ingenio está más bien alejado de esta. Sin embargo, en la intención de racionalizar lo divino y de darle una disciplina, es posible observar que incluso una capacidad creadora como el ingenio pueda ser teorizada y crear así un arte para esta.

Juan de Jáuregui y Aguilar, Discvrso poetico (1624)

La última poética discursiva del corpŭs se caracteriza por ser una advertencia del "desorden i engaños de algunos escritos" (f. 1r). En esta, a lo largo de sus seis capítulos, el ingenio posee una importancia indiscutible. Con sus treinta y cinco menciones en tan solo ochenta folios, el término muestra tanto una mayor frecuencia cuantitativa en comparación con el resto de las poéticas, como una mayor implicación en la producción poética, aún y cuando se le acompaña casi siempre por el arte o el stŭd̆̌um. El equilibrio entre estos términos corresponde, sin duda, al tono moderado que Melchora 
Romanos ha reconocido en esta obra ${ }^{497}$. Sin embargo, por la manera en la que se explota el carácter creador y receptivo del ingenio, Jáuregui se aleja se aleja de una tradición en donde el entendimiento y el juicio tenían sus respectivos papeles

En concordancia con la tradición italiana de la cual se nutre la estructura del Discvrso ${ }^{498}$, el primer capítulo, "Las causas del desorden, y su difinicion”, establece el objeto y la justificación de la $\overline{\text { orātĭo }}{ }^{499}$. Esto son, respectivamente, la poesía moderna ${ }^{500}$ y la necesidad de advertir de sus peligros, debido a la carencia de profundidad de otros discursos que tratan la misma cuestión ${ }^{501}$. Asimismo, trata justamente de la definición y las causas de tales peligros, descritos como la "Estrañeza, i confusión de los versos [...,] quexa ya universal entre quantos conocen, o bien desconocen nuestra Lengua" (loc. cit.). Es importante recalcar desde ahora que la defensa de la lengua es un pilar central en el Discvrso -como ya anoté (vid. "Capítulo II")-, por lo que es un argumento leitmotiv en contra de la poesía moderna y a favor de su "advertencia".

Ahora bien, otro de los argumentos constantes en la poética es el repudio que la poesía moderna provoca en el público por no conseguir el mŏvēre, lo cual es una falta gravísima al ser la causa final privilegiada en el Barroco español, como afirma la hispanista Aurora Egido ${ }^{502}$. Siguiendo este principio, Jáuregui, al iniciar su poética, califica a los receptores de la poesía moderna como "buenos juizios", que "se co[m]padecen, viendo el disfraz moderno de nuestra poesia" (loc. cit.). El

${ }^{497}$ Vid. "Don Juan de Jauregui: vida y obras”, en Juan de Jáuregui, Discurso poético, M. Romanos (ed.), p. 31. Sobre esto el crítico Juan Matas Caballero comenta: "La dualidad ingenio-arte se había convertido para Jáuregui en el santo y seña que acompañaba a toda reflexión sobre la esencia del creador y del fenómeno poético. Frente a la tendencia generalizada en el Barroco de mantener la superioridad del primero sobre el segundo, nuestro autor se muestra partidario de la imprescindible confabulación y concertación de ambos conceptos poéticos, optando de esa manera por una postura ecléctica y conciliadora entre platonismo y aristotelismo" (Juan de Jáuregui. Poesía y poética, p. 235). La observación del hispanista parte de una revisión total tanto de la obra teórica del sevillano como de su producción poética. Sin embargo, es innegable que su poética discursiva es la que más recurre a esta conciliación debido a que el sevillano cuida mucho no atacar directamente a un autor en particular. Así, el tono polemista del Antídoto, por ejemplo, desaparece de cierta manera.

${ }^{498}$ A propósito de la estructura y tradición del Discvrso vid. Mercedes Blanco, “Introducción” a Juan de Jáuregui, Discurso poético, M. Blanco (ed.), s. p. (disponible en línea: https://obvil.sorbonneuniversite.fr/corpus/gongora/1624_discurso-poetico\#body-1-1).

${ }^{499}$ El carácter retórico formal de la poética es explicado también por Mercedes Blanco quien afirma que si "el adjetivo 'poético' remite a la materia, la forma se indica en el sustantivo 'discurso'. Equivalente romance del latín oratio, denota un tratamiento retórico y no filosófico o técnico del tema. Un discurso, a diferencia de un tratado, no tiene propósito didáctico sino oratorio: no enseña dogmáticamente una ciencia o ars, sino sustenta una tesis acerca de una cuestión controvertida; por ello, suele ser relativamente breve. El subtítulo permite precisar algo más de la índole del discurso situándolo a medio camino entre el género deliberativo (por qué y cómo debemos guardarnos del 'desorden y engaños de algunos escritos') y el género demostrativo, en su vertiente de censura y vituperio. El encabezamiento del texto apunta, pues, a un texto polémico, pero en términos mesurados y cuya finalidad declara no es ofender, sino advertir" (loc. cit.). Efectivamente, el tratamiento formal del Discvrso es retórico; sin embargo, debido a que posee tanto el género deliberativo como demostrativo, la poética de Jáuregui no deja de ser prescriptiva. Por lo tanto, aunque dista formal y prácticamente de las poéticas dialógicas, cuyo un propósito didáctico es explícito, no deja de ofrecer una imagen del poeta ideal para Jáuregui y las pautas esenciales para llegar a serlo.

${ }^{500}$ Quiero recordar que este apelativo es usado despectivamente por Jáuregui para denotar una poesía alejada de

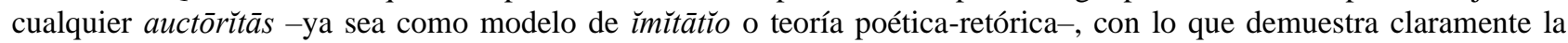
ignorancia y falta de maestría del poeta, así como la poca dignidad y validez de una obra que no cumple con las bases del arte (vid. "Capítulo II").

${ }^{501}$ Vid. "Al excelentissimo Conde", dedicatoria de la poética (s. f.).

502 Vid. "La hidra bocal", pp. 88-89. 
poeta sevillano enfatiza que el disfraz de esta poesía es evidente. No obstante, hay un grupo entre estos juicios que por su "modestia [...] llegan a mostrarse dudosos, sobre si este modo de escrivir, siendo a todos molesto, es en alguna manera acertado; si esconde misterios de ingenio; si alguna utilidad, o circunstancia oculta por do[n]de merezca estimarse, i ser admitido delos nuestros" (fols. $1 \mathrm{r}-\mathrm{v})$.

Juan de Jáuregui, a través de su captātı̌o běněvŏlentǐae, establece su público principal. Además, con la fórmula exordial de ăb iudicum persōna, le atribuye un buen juicio: "potencia o facilidad intelectual, que le sirve al hombre para distinguir el bien del mal, y lo verdadero de lo falso" 503 . El juicio del público, pese a ser bueno -nunca se afirma lo contrario-, puede albergar por su modestia ${ }^{504}$ la duda de que la poesía moderna sea correcta y que efectivamente guarde algunos “misterios de ingenio". Dicho de otra forma, se pregunta si tales obras poseen algún misterio obtenido con ayuda del ingenio y por ello sea de utilidad.

De esta forma, Jáuregui alude una característica que está relacionada con el entendimiento agudo de Carrillo y Sotomayor, al penetrar en la realidad y encontrar conceptos sublimes, o bien, "misterios". Además, como Pinciano y Carvallo, el poeta sevillano concibe al ingenio como una capacidad receptora y develadora de la realidad. Esto último también comienza a desdibujar la cercanía con lo divino que el ingenio tiene en el Discvrso y demuestra la tradición a la que pertenece Jáuregui y que comparte con Herrera, Carvallo y Carrillo y Sotomayor ${ }^{505}$.

Es importante hacer énfasis en que el ingenio no es inherentemente divino, sino cercano. En el Discvrso existe una fuerza externa - de carácter extranatural-que influye sobre la capacidad natural y la saca de sí, de forma similar a cómo el furor funciona en el Cisne. Dicho aspecto afianza aún más la relación entre ambas teorías poéticas, aunque es imperativo precisar las particularidades del furor o, mejor dicho, del aliento de Jáuregui.

En concordancia con el tono conciliador del Discvrso, se emplea un tópico a persōna tempŏrārŭum ănĭmi mŏtŭm - para referirse al poeta furioso y se concede que la intención creativa es cierta y válida. De la misma forma que Horacio ya había establecido en su poética, Jáuregui afirma:

la suma de mi persuasio[n], que el inte[n]to original de los autores propuestos, en su primera raiz es loable: porque sin duda los mueve un aliento i espiritu de ostentarse bizarros i gra[n]des: mas engañados al elegir los medios yerran en la execucion, tanto que los efectos

${ }^{503}$ Diccionario de la lengua castellana..., s. v. juicio (disponible en línea: http://web.frl.es/DA.html).

${ }^{504} \mathrm{El}$ término está acorde con el tono moderado del Discvrso, ya que es la "suma templanza o moderación en el mirar, y compostura y recato en los ojos" (id., s. v. modestia). Me parece pertinente mencionar que la modestia está relacionada con la "vista", mientras que a lo largo de la poética de Jáuregui el sentido que se privilegia es el del "oído", ya que es este, por ejemplo, el que determina la calidad del verso. Por lo tanto, se explica que estos juicios modestos se equivoquen en su razonamiento, pues se basa solo en un sentido que no es propio de la poesía.

${ }^{505}$ Bien señala Miguel Herrero García: "La descendencia por línea directa de Herrera son Jáuregui, Paravicino, Quevedo, Carrillo Sotomayor, Calderón y toda la obscura cáfila de poetas culteranos" (Estimaciones literarias del siglo $X V I I$, p. 252). El crítico piensa en el aspecto poético, pero es evidente que se comparte una estética y, por ello, una teoría literaria, de la que es partícipe Carvallo y no solo, sino también Pinciano e incluso Huarte de San Juan. 
son vituperables, i justamente aborrecidos; no en parte alguna utiles, antes en estremo dañosos a nuestra lengua i patria. (fols. 1v-2r)

El aliento y espíritu inflaman a los poetas y los motiva a buscar la grandeza: la fama, que ofrece inmortalidad, como es bien sabido desde la tradición clásica. No obstante, el aliento no crea y no penetra en altos misterios, sino que afecta otras capacidades del poeta y las incita a la búsqueda y creación. En este fragmento, no se especifica que sea el ingenio la capacidad afectada, pero se puede inferir de su primera mención pues es el encargado de hallar los "misterios".

Ahora bien, otra peculiaridad de este aliento es la obligación que tiene el poeta de encauzar correctamente su motivación y no dejarse llevar por el trance en que tal espíritu lo sumerge. Si lo permite, este lo haría errar en la "execucion" y volvería su obra inútil e incluso perniciosa. Para evitarlo, el poeta aconseja inmediatamente el "arte i estudio" (f. 2r) que permite distinguir los vicios de la virtud -otro gran tópico del Discvrso.

El arte y el stŭdĭum (que recuerda sin duda a la erudición carrillesca) son pues los pilares que contiene al aliento. La balanza arte-ingenio se equilibra, pero también se complejiza con el stŭd̆̌um que se sustenta con el ejercicio constante. Jáuregui siempre advierte de los peligros de no proceder de esta forma, por lo que agrega que el que ignore el arte y el stŭd̆̌um, solo logra "levantar la poesia en gran altura, i pierdense por el excesso" (f. 2v). En la poética discursiva, el vuelo debe ser controlado.

Con base en lo anterior, es claro que el resultado de dejarse llevar solo por el aliento y no atender ni el arte ni el stŭdŭum repercute directamente en el aspecto poético que más preocupa y se discute en el Discvrso: el estilo. Este requiere particularmente de la técnica producida por el arte y el conocimiento del stŭd̆um. Así pues, la carencia de estos se muestra en un estilo ajeno a la grandeza buscada - un estilo moderno-, ya que solo se basa en este primer impulso del aliento. Por tanto, prima el vicio de la "temeridad, hinchazon, i viento, [al cual] es acierto llamarle ta[m]bien frialdad; porq[ue] prete[n]diendo un ingenio estremos briosos, consigue solo desaires frivolos; i en vez de agradar al oyente, i mover su espiritu, le desgracia, i le yela" (fols. 3r-v).

Jáuregui alude a una capacidad creativa que todo ingenio humano posee. Por esta razón, sus creaciones pueden estar equivocadas - “desaires frivolos"-, pese a que su intención sea buena pretender "estremos briosos". Entorpece luego el mŏvēre del receptor y lo "hiela". Las metáforas del estilo "frío" y sus efectos "helados" -que el poeta sevillano recupera del texto de Teofrasto, Пعpì

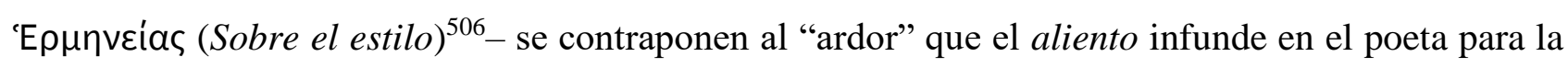
exaltación del ingenio. El resultado, con ayuda del ars y stŭdı̆um, crea obras que inflaman igualmente

\footnotetext{
${ }^{506}$ Jáuregui no cita directamente al autor griego y usa la traducción al latín del italiano Pietro Vettori (vid. fol.
} $3 r)$. 
al receptor. Con base en lo anterior, observo que dentro el Discvrso la causa eficiente depende fundamentalmente del arte y stŭdı̆um, por lo que la ausencia de alguno de estos tres afecta directamente la causa material, creando un estilo frío incapaz de conseguir la causa final de la poesía: el mŏvēre.

Como ocurre en el Cisne y en el "Libro", el Discvrso para su argūmentātǐo recurre constantemente a la amplüfícātĭo ${ }^{507}$ a través de la commŏrātĭo. De tal manera, se ahonda en los efectos perniciosos de una poesía basada en la demasía elocutiva. Jáuregui recupera entonces un término de la tradición griega a través de autores latinos como Luciano, Séneca y Quintiliano, y por el preceptista italiano Escalígero ${ }^{508}$ : la cacocelía.

Esta perdicion por execessos, cuyo efeto es frio, hinchado, i temerario, es tambien una suerte

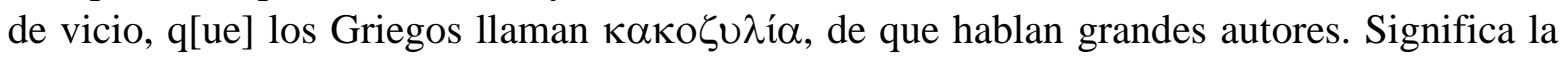
voz Cacozelia, un mal zelo i vituperable por demasiado; una afectacio[n] i veheme[n]cia por adela[n]tar nuestras fuerças, i passar a impossibles, perdie[n]donos en la prete[n]sion. (f. $3 \mathrm{v}$ )

Los versos horacianos dedicados a las fuerzas de los poetas (vv. 38-40) -uno de los tópicos privilegiados de la estética renacentista - hacen eco en este término usado principalmente en el ars rhètǒrǔca latina.

Dicha cacocelía ocurre entonces cuando se falla en la búsqueda de mesura -de raigambre aristotélico-, que se entorpece en el momento en que las "fuerças" - 'ingenio'- del poeta y lo que intenta conseguir no coinciden. Señala Jáuregui a continuación:

Este es error primitivo, i el vicio capital en q[ue] oi incurre[n] los ingenios de que tratamos. Quieren salir de si mismos por estremarse: i aunque es bien anhelemos a gran altura, suponese que esos alientos guarden su modo, i su termino, sin arrojarse de manera, q[ue] el buelo sea precipicio; i por alcançar al estremo, aun no lleguemos al medio. (loc. cit.)

Luego, la cacocelía es un error presente desde la antigüedad y en el que incurren un determinado tipo de ingenio -el término vale también aquí como metonimia de "poeta". Este desconoce la manera de templar el aliento inicial que lo motiva al "vuelo" poético, por lo que termina cayendo no solo al suelo, sino a un precipicio ${ }^{509}$. Por decirlo de otra forma, son ingenios incontinentes precisamente porque sin la guía de arte y stŭdŭum no saben encauzar correctamente el ardor que lo ha inflamado. Nuevamente, Jáuregui afirma que el problema de estos ingenios no está ni en su fecundidad ni en la capacidad que tiene para recibir el aliento, en el cual tampoco radica el error.

${ }^{507}$ Es evidente que esta característica tan recurrente en la poesía del siglo XVII (vid. A. Egido, "La hidra bocal”, pp. 98-100) se encuentra también en las poéticas. Así, teoría y práctica se relacionan estilísticamente, demostrando la forma en que ambas producciones comparten y parten de una misma estética.

${ }^{508} \mathrm{Vid}$. fol. $3 \mathrm{v}$, i. m. Mercedes Blanco anota largamente el término de la cacocelía que fue a su vez un tópico en la disputa gongorina (vid. J. de Jáuregui, Discurso poético, M. Blanco ed., n. 169, s. p.).

509 Junto a las metáforas de ardor/fuego y frío/helar, el conjunto de similitudes de tradición platónica como vuelolelevarse se contraponen a la caída-despeñar. Asimismo, el precipicio se conforma como una de las metáforas poéticas lexicalizadas favoritas de Jáuregui para argumentar su prōpǒsĭť̆o. 
El tratado de Séneca, De tranquillitate animi $(6,17, \S 11)^{510}$, es la auctōrĭtās que en el Discvrso valida la existencia un "espiritu mayor poetico" llamado también: "furor, manì, o insania" (loc. cit. $)^{511}$. Este, siguiendo la tradición de los furores platónicos, es un "ardor" o un "arrorobo"

tan alto [que] compete a los grandes poetas. no [sic] es menos lo q[ue] debe el ingenio moverse i excitarse, si propone a sus obras aplausos superiores. Mas deve (quie[n] lo duda?) co[n]seguir bue[n] efeto destos ardimie[n]tes, i raptos: enplearlos digo principalme[n]te en co[n]cetos sublimes i arcanos (de q[ue] habla Seneca) no en lo inferior i vazio de las palabras, con que solo se enfurecen algunos. (fols. $4 \mathrm{r}-\mathrm{v}$ )

No hay ninguna duda sobre el carácter especial que el furor otorga al ingenio, puesto que compete únicamente a los "grandes poetas". Sin embargo, su superioridad no vale nada por sí misma, así como tampoco lo hará el ingenio excitado con su ardor si no consigue la causa final de la poesía.

En este fragmento, el decoro se extiende a la concordancia entre rēs y verba-los "co[n]cetos sublimes i arcanos" y las palabras- que, además de acercarse al ámbito de lo divino, se asocia con la tradición clásica, contraponiéndose así con la modernidad de la poesía criticada. Jáuregui reitera que el vicio de la poesía moderna no se origina con el ardor o con la excitación que provoca en el ingenio, sino en el "vazio de las palabras". Me pregunto entonces si tal vicio de la élŏcūtǐo es un defecto de la causa eficiente o no. En el Discvrso no parece ser así. De hecho, no es un error del ingenio únicamente, es un fallo de los diversos factores que intervienen en la creación poética, aunque el inicio del vicio se da en la incapacidad de controlar al furor, tarea que no compete directamente al ingenio.

Jáuregui mencionó anteriormente que en el "precipicio" termina el vuelo de los ingenios creadores de la poesía moderna al no saber encauzar el aliento que los "estrema". Ahora, como commŏrāť̌o de lo anterior, agrega: "I como quiera q[ue] se arroje el espiritu, debe salir a salvo del peligro, que es todo el ser de las empresas; i en las de poesia, tan dificil; que pide gra[n] fuerça de ingenio, estudios copiosos, artificio i prude[n]cia admirable" (f. 4v). El "espiritu" al que se refiere el poeta sevillano es el "espiritu mayor poetico" (f. 3v), que implica al ingenio poético, pero no solo, ya que el espíritu comprende también el "alma racional" 512 del ser humano.

Entonces el espíritu del poeta debe salvar los peligros a los que el exceso del ardor lo exponen -lo que da una dificultad específica a la empresa poética. Para esto, se exponen las cualidades

${ }^{510}$ Vid. Juan de Jáuregui, Discurso..., M. Romanos (ed.), p. 67, n. 14.

511 Quiero anotar que al furor nunca se le llama ingenio, por lo que se confirma la distinción entre ambos términos. Esto, aunado con la definición del ardor, permite afirmar que tal fuerza es externa al individuo; mientras que el ingenio es la capacidad humana que se inflama como consecuencia de tal fuerza. El paralelismo entre el Cisne y el Discvrso es innegable.

512 Vid. Diccionario de la lengua castellana..., s. v. espíritu. Recuérdese también la división hecha por Pinciano en la "Epistola primera" de la Philosophia entre la parte animal y racional del humano, en donde la segunda lo acerca a la divinidad angélica. 
requeridas en el poeta: gran fuerza de ingenio ${ }^{513}$, estudios copiosos -el plural evidentemente aclara que son múltiples las materias que debe conocer el poeta-, artificio y gran prudencia. El poeta sevillano identifica en el Discvrso las cualidades que "an de asegurar el furor" (f. 4v), entre las cuales el ingenio ocupa el primer lugar. Su gran fuerza -la gran fuerza creadora del ingenio- corresponde a la inventı̆o (propia de la causa eficiente), mientras que el resto de los requisitos aluden al resto del proceso creativo y representan la preparación y disposición del espíritu poético. De esta manera, el poeta evita que la inflamación del ingenio se decante por el vicio primitivo del "vazio de las palabras".

Así pues, ya que es grande la fuerza del ingenio, la prudencia -una "de las quatro virtudes cardinales que enseña al hombre a discernir y distinguir lo que es bueno o malo" 514 - debe ser “admirable”. En lugar de seguir la tradición de Quintiliano y considerar el juicio como la capacidad que guía al ingenio, Jáuregui determina que es la prudencia aquella que discierne entre el bien y el mal, o bien, entre la virtud y el vicio poéticos ${ }^{515}$-en concordancia con un campo semántico religioso que construye en su poética ${ }^{516}$. El poeta no puede dejar que su capacidad creativa-su gran fuerza del ingenio-domine todo el proceso poético. Es necesario entonces que cuente con una formación y otras capacidades del "espiritu mayor poetico" para conseguir el decoro entre rēs y verba, sublimando así su poesía.

A estos preceptos se contrapone la práctica poética moderna, que pretende "con el aliento solo co[n] seguir maravillas sin costa" (loc. cit). Dar la espalda al stŭdŭum, el arte y la prudencia condena al ingenio de estos poetas a equivocarse:

Porque no son sus extasis, o raptos en busca de peregrinos concetos: remotos van sus ingenios desse rumbo. Por locuciones solas se inquieta[n], i en tan leve designio se pierden. Con este solo viento desatan las velas todas al impetu de su furor, i pretendiendo navegar velocissimos, çoçobra la nave, i se anega, como provarà este Discurso. (loc. cit.)

Con otro tópico clásico -el poeta que navega-, Jáuregui evidencia cómo el ingenio impulsado con el éxtasis explota una ēlǒcūtǐo vacía puesto que solo se compone de "locuciones". No hay forma posible

${ }^{513}$ Este sintagma -la fuerza del ingenio- es usado por Aurora Egido para indicar el triunfo del ingenio en la obra cervantina. La hispanista, empero, en ningún momento se refiere a la poética de Jáuregui, posiblemente porque a diferencia del poeta sevillano, Cervantes explota la capacidad natural del poeta tanto en la inventǐo como en la élöcūť̆o, evidente además en el mŏdus vīvěndi y discurso de sus personajes (vid. Egido, Aurora, "La fuerza del ingenio y las lecciones cervantinas", BRAE, t. XCVI, cuaderno CCCXIV (2016), pp. 771-791 passim). Pese a esta distinción sustancial, considero relevante esta relación sintagmática, ya que enmarca precisamente la importancia del ingenio en los Siglos de Oro, cuya fuerza permea cada una de las obras creativas y teóricas.

${ }^{514}$ Diccionario de la lengua castellana..., s. $v$. prudencia.

${ }^{515}$ La prudencia es una capacidad fundamental para controlar los excesos poéticos; sin embargo, es innegable que la principal herramienta que los contrarresta son los "copiosos estudios", de ahí que ocupe el segundo lugar de las cualidades poéticas deseables. Dicho de otra forma, la aparición de las cualidades ideales del poeta implica una jerarquización en el proceso creativo.

${ }^{516}$ Nótese, por ejemplo, que la cacocelía es un "vicio capital" (fol. 3v). El uso de términos religiosos es para la construcción de otra metáfora en el Discvrso, una que considera a la poesía como divina y a los poetas modernos como pecadores. Considero que la condena no es menor si se piensa en las implicaciones de las palabras impío, vicio o pecado poseen en una España contrarreformista. 
de que solo el aliento y el ingenio inflamado por este puedan conseguir la causa final de la poesía, porque los "peregrinos concetos" en los que se empeñan no son los “co[n]cetos sublimes i arcanos". Como ocurre en el "Libro", el carácter sublime de la poesía es innegable, pero el ingenio puede y debe ser acompañado de otras cualidades para evitar el "vicio capital" de la cacocelía, el estilo hinchado y frío.

Durante el capítulo II, "Los engañosos medios con que se yerra", se trata directamente la causa material de la poesía y cómo en esta radica el error de la producción que Jáuregui llama moderna, debido a que toma "engañosos medios" para conseguir su finalidad. Así, el "aborrecimiento de palabras comunes" (f. 5v) es uno de los principios poéticos que pueden confundir al poeta. El conocido tópico horaciano ōdi profanum vulgus ĕt ărceo -que cimienta de forma importante el elitismo intelectual también en el "Libro"- se convierte en un vicio poético únicamente cuando los poetas "llenos de furiosa afectacion, no solo buscan vozes remotas de la plebe, sino del todo ignoradas en nuestra lengua, i traidas en abunda[n]cia de las agenas" (loc. cit.) ${ }^{517}$. Jáuregui ataca el uso excesivo de extranjerismo en la poesía moderna, primero porque la materia poética no justifica su uso ${ }^{518}$, son perniciosos para el castellano $\mathrm{y}$, finalmente, en su lengua de origen son incluso oscuros ${ }^{519}$, entorpeciendo la persp̌̌cǔ̆tās propia de la poesía.

Asimismo, las “metáforas alentadas, i otras figuras i tropos admirables" perjudican a la obra poética por el exceso y la violencia con que los poetas modernos las utilizan, pues "siempre los fuerçan a que sirvan do[n]de nu[n]ca pensaron, del todo repugnando al oficio en que los ocupan" (f. 8v). Los ingenios de los que trata el Discvrso no han sabido tampoco en este caso hacer uso mesurado y correcto de las fígūrae èlŏcūtǐonis. Para contrarrestar esto, Jáuregui recupera la auctōrǐtās de Gerónimo de Vida, una auctōrìtās que para el poeta era mejor que Horacio en cuanto a la enseñanza

${ }^{517}$ Es importante tener claro que solo se trata de un vicio cuando es el furor quien prima en la búsqueda de palabras ajenas al vulgo, porque Jáuregui sabe que el "estilo poetico debe huir las dicciones humildes, i usar las mas apartadas de la plebe” (fol. 5v). Por tal motivo, Antonio García Berrio reconocerá en las teorías poéticas de Carrillo y Jáuregui el desarrollo de la teoría horaciana, quien "había manifestado en otras obras perfectamente explícita la autoconciencia aristocrática de su poesía y el eco y acatamiento de la misma que le transmitía su público: la más terminante y clara de todas aquellas menciones se cifraba en el rotundo, para la mentalidad de la época, odi profanum vulgus. A esa proclamación escasamente problemática acudían invariablemente nuestros polemistas de la poesía barroca para reforzar sus opiniones, cuestionables como personales y circunstanciadas. Así, al juicio de Horacio apelaba ya el primer alegato consistente a favor de la renaciente estética barroca, el Libro de la erudición poética de Luis Carrillo y Sotomayor [...] Pero, como en la mayoría de estos tópicos vinculados a la mención y la presencia horaciana, será el Discurso Poético de Juan de Jáuregui la obra en la que ésta se haga más variada y plena de rendimiento" (Formación de la Teoría Literaria moderna, 2, p. 196). Como la cacocelía, la presencia del tópico horaciano es bastante recurrente en las poéticas del siglo XVII español, pero es Jáuregui quien a través de la amplüfĭcātǐo y la vărīātǐo del lugar común, le otorga estos matices en donde también puede encauzar por error a un vicio poético.

518 Jáuregui refiere el capítulo 22 de la Poética de Aristóteles para asegurar que las "palabras de otras lenguas competen al estilo eroico" (fol. 5v).

${ }^{519}$ Vid. fol. 8r. 
del ars pǒetrica ${ }^{520}$. Vida "considera ingeniosamente" dicha "violencia de translaciones" (loc. cit.) como un despojo de "las cosas de su forma nativa a pesar dellas mismas, i obligadas viole[n]tamente a vestirse de agenos aspectos" (f. 9r) ${ }^{521}$. Me parece que tal afirmación es ingeniosa por la capacidad que el poeta cremonés tuvo para discernir el quid de este error poético. Por lo tanto, en este adverbio de modo se puede afirmar que se alude a la capacidad receptora del ingenio.

Esta misma cualidad está presente en la siguiente mención del término que, además, ahonda en la obscūrĭtās de los modernos. Jáuregui continúa describiendo los vicios poéticos en los que tan frecuentemente incurren sus contemporáneos y enfatiza cómo la sínquisis ${ }^{522}$ se opone al "estilo magnifico". Es verdad que este último "deve huir el camino llano, la carrera de locucion derecha co[n]secutiva, i la cortedad de las clausulas", pero los poetas “porfian en trasponer las palabras, torcer i marañar las frases, de tal manera; que aniquilado toda gramatica, derogando toda lei del idioma, atormenta con su dureza al mas sufrido leyente" (f. 9v). El resultado de esta aniquilación gramatical y sintáctica es manifiesta en el lector ${ }^{523}$ a los que "con ambigüedad de oraciones, revolucion de clausulas, i lo[n]gitud de periodos, esconden la inteligencia al ingenio mas pronto" (loc. cit.). Entonces, la obra poética creada de esta forma es tan ambigua e intrincada que no es inteligible ni siquiera para un ingenio bien dispuesto. Por lo tanto, la capacidad receptora de la que se trata aquí y que es equiparable a la anterior-alude evidentemente al ingenio del receptor de la obra poética y no del poeta.

Ahora bien, el Discvrso explica que los vicios en los que incurren los modernos no pueden ser solucionados por su incapacidad de identificarlos como tal, en contraste evidente con el comentario ingenioso de Vida y con la nota aguda que Quintiliano hace a propósito de la cacocelía. La traducción que Jáuregui hace de las Instǐtūtǐo ŏrātōrǐa (VIII, 3, § 56) ${ }^{524}$ reza: “Cacozelon [...] se llama lo q[ue] excede allende la virtud. Sie $[m]$ pre $q[u e]$ el ingenio carece de eleccion i juicio, $i$ se engaña con una especie de bueno; es en la eloquencia el pessimo de todos los vicios: por $q[$ ue] los demas se huye[n], i este se busca" (f. 12v). En estas líneas se observan algunos de los principios del Discvrso que ya se

\footnotetext{
${ }^{520}$ Como efectivamente comenta la estudiosa Mercedes Blanco, este es un juicio que Jáuregui toma de la poética de Escalígero (vid. loc. cit.). Observo por tanto cómo el tejido teórico de la época se construía por un lado con base en consideraciones personales y por otro en tópicos de raigambre clásico, pasados en ocasiones por la teoría italiana.

${ }^{521}$ La cita en cursivo es una traducción del poeta sevillano del Poeticorum libri tres, III, vv. 153-155 de Vida (vid. J. de Jáuregui, Discurso poético, M. Blanco ed., n. 217, s. p.).

${ }^{522}$ En el Discvrso no se usa este nombre para definir esta figüra, pero se puede inferir por la descripción que se hace de la misma.

${ }^{523}$ Es bastante significativo que aquí Jáuregui se refiera a los "leyentes" y no a los "oyentes" como sí hace posteriormente. Sin duda, lo hace para recalcar la confusión creada por la poesía moderna, pues sus trasposiciones de palabras y cláusulas no son detectadas por el oído, sentido que privilegia el poeta sevillano, y tampoco por la vista que permite detenerse más en el análisis del poema.

524 Como comentan sus editoras modernas, en el Discvrso se cita erróneamente el capítulo del fragmento traducido, ya que se dice que es el segundo (vid. $12 \mathrm{v}, i . m$.), cuando en realidad se trata del tercero (vid. J. de Jáuregui, Discurso poético, M. Blanco ed., n. 246, s. p.; e ID., Discurso poético, M. Romanos ed., p. 85, n. 43).
} 
han discutido, lo que demuestra cómo habían sido asimilada y resignificada esta definición del rhètŏr latino por parte del pintor poeta.

Cabe destacar que el juicio es la capacidad que acompaña aquí al ingenio para evitar engaños que parezcan buenos y no la prudencia que continúa la metáfora religiosa del Discvrso. Sin embargo, el trasfondo de este fragmento se mantiene: el ingenio no puede crear por su cuenta sin el peligro de caer en el vicio de la cacocelía. Por ende, la poética discursiva de Jáuregui puede considerarse parcialmente como una poética retoricada. Como ocurre en el Cisnes, esto no afecta la vertiente hedonista a la que pertenece, ya que no niega en ningún momento el aliento como origen de la alta poesía. Sin embargo, se cuida una y otra vez de afirma la existencia de un poeta alentado que dependa únicamente del ardor.

En el capítulo III, “La molestia frecuencia de novedades”, Jáuregui enuncia otro vicio con el que los poetas modernos pecan en sus obras y que consiste en la "repeticion tan viciosa de unos modos mismos o frases" (f. 13v). Dichos modos o frases son las novedades, que para el poeta sevillano son viciosas en sí mismas: "las novedades poeticas, i osadias de eloquencia, aunque se acierten, son de $s u$ naturaleza culpa o vicios" (f. 14v). Sin embargo, estas pueden ser producto de una "curiosa felicitas" como la que Petronio identifica en la poesía de Horacio ${ }^{525}$, quien habría demostrado así ser "feliz en lo vicioso; que excedio venturosame[n]te" (f. 15r). Las novedades, como señala Mercedes Blanco $^{526}$, revelan la figura del poeta como vate inspirado, con lo que Jáuregui vuelve a equilibrar la balanza entre lo sublime de la poesía y el arte y stŭdŭum que deben siempre acompañarla. Esto permite a Jáuregui aceptar la posibilidad de "vicios felices" que "en manos de algunos, por su mal artificio pierden la gracia" y “assi en las de otros por su buena industria los mismos vicios deleitan" (f. 16r).

En concordancia con lo anterior, Jáuregui glosa un fragmento de las Noches áticas (XIII, 20) ${ }^{527}$, donde se comparan las diferentes “singularidades" -'novedades'- presentes en "Lucrecio i Enio, como en Ciceron, Virgilio i Omero, i pondera sus ingenios i arte, que consultando el buen gusto

\footnotetext{
${ }^{525}$ La cita es identificada por Melchora Romanos en el Satiricón, § 118 (vid. J. de Jáuregui, Discurso poético, M. Romanos ed., p. 90, n. 4).

${ }^{526}$ A propósito del término "curiosus", Jáuregui establece una relación entre el "poeta felizme[n]te curioso" y el "mago o hechizero" (fol. 15v), a partir del texto de Lorenzo Ramírez de Prado. Con base en esto, la hispanista observa: "la curiositas, voluntad de saber cosas arcanas y vedadas a los hombres, aunque condenada como vicio, no deja de ser una virtud del poeta, en cuanto vates inspirado y visionario. Esta contradicción, resuelta felizmente por Horacio con su felix curiositas (análoga a la felix culpa que es el pecado original según célebre fórmula de San Agustín) confiere al extravío estético reprochado a los gongorinos un matiz de infracción religiosa” (J. de Jáuregui, Discurso poético, M. Blanco ed., n. 263, s. p.). Aquí observo que tanto el eclecticismo como la metáfora religiosa ayudan a Jáuregui a mantener el tono moderado y reconciliador entre las teorías poéticas de la época y la tradición grecolatina. El poeta mantiene entonces su divinidad, pero se le alerta de que puede caer en el pecado de la desproporción.

${ }^{527}$ Este pasaje también está citado con imprecisión según cotejan sus editoras modernas, ya que la nota al margen del Discvrso indica que se trata del capítulo 9 (vid. J. de Jáuregui, Discurso poético, M. Blanco (ed.), n. 273, s. p.; e ID., Discurso poético, M. Romanos (ed.), p. 94, n. 23); esto, posiblemente, demuestre que Jáuregui citaba a algunas de sus fuentes de memoria o con ayuda de apuntes, ya que aquí, a diferencia de otros momentos, no se cita el texto latino.
} 
del oido, hallaro[n] sazones de hermosear las fealdades, i virtualizar los vicios" (f. 17r) ${ }^{528}$. Según Jáuregui, Aulio Gelio parte de dos cualidades poéticas para establecer sus juicios de valor: el ingenio y el arte; de estos depende para volver hermoso lo feo hermoso y virtud el vicio. En otras palabras, el binomio arte-ingenio es el que sublima la ēlŏcūť̆o poética y le da su carácter de verdad. Por ende, carecer de tal capacidad natural y método provoca únicamente que los poetas "falsean tanto el estilo que es toda su poesia falsedad, i los autores (si es licito dezirlo) falsarios" (f. 17v).

La veracidad del discurso poético y su validez estética recae así en la èlŏcūtřo que pone en evidencia la gran fuerza del ingenio y el arte que la moldea. El estilo poético sublime es el resultado del trabajo en armonía de este binomio arte-ingenio -aspecto en el que considero ya se vislumbra la creación de un ars ingěnĭum. Dicho estilo se caracteriza por la concordancia entre la verba con los conceptos igualmente sublimes (rēs). Por ello, el desfase entre estos y, en especial, de la verba con respecto a la rēs rompe con el decoro, provocando el odio del escucha. Sin embargo, en la ēlŏcūtı̆o puede existir otro desface entre las "maneras altivas del dezir" (f. 17v) y el resto de la verba.

Por lo anterior, en el capítulo cuarto, "El vicio de la desigualdad, $i$ sus engaños", se afirma que el estilo debería ser "continuamente grande" (f. 18r), de lo contrario se origina aquello que Jáuregui denomina "vicio de la desigualdad" (f. 17v). Para evitar tal vicio, reitero, no se prescribe un mediocris o hümŭlis stylus, sino que se concede la presencia del "buelo sublime" (f. 18r) y por ello no se debe "restringir al poeta en pu[n]tuales gramaticas" (f. 18v). De lo contario, solo se seguirá un "camino real i trillado [...] como si a la dificil de Elicon se pudiesse llegar por camino llano" (f. 18v), justo lo que desea evitar Jáuregui en todo sentido. La balanza entre lo sublime y la armonía -uno de los principios más importantes del Discvrso- se evidencia y la primero de estas cualidades se justifica por las capacidades del ingenio.

El sevillano afirma:

Licito es, i posible al ingenio contravenir muchas veces a la regulada eloquencia i sus leyes comunes, sin ofender las poeticas, antes ilustrando sus fueros, aspirar deve a grandiosas hazañas, i no medianas: porque no solo la humildad i rendimiento es indigno en los versos, sino tambien la llaneza, i la mediania; (yà lo predica Oracio) i aunque sea pareja i sin vicios, es viciosa, i ta[n] despreciable, que no halla lugar en poesia. Mas ta[m]poco le tiene la grandeza i sublimidad, si es pocas veces co[n]seguida, i las mas alternada co[n] precipicios. (fols. $18 \mathrm{v}-19 \mathrm{r}$ )

Como se ha advertido desde los primeros folios, el ingenio inflamado por el aliento es la capacidad creadora que "debe" aspirar a "grandiosas hazañas". Es precisamente este deber - nótese el modal de obligación- el que le permite al poeta alejarse del camino llano y elevarse al monte de las Musas: “a la dificil de Elicon". Para esto se contravienen las leyes de la elocución regulada -con alusión

${ }^{528}$ En contraste con los "leyentes" que se confunden con el excesivo uso de la sínquisis, los ingenios clásicos han conseguido su excelencia gracias al "buen gusto del oido", el sentido que permitirá la perfección estética de la poesía. 
evidente a la estética retórica-, sin por esto romper la prescripción de las poéticas. De hecho, esto no ocurre porque todas ellas admiten las licencias poéticas originadas con la gran fuerza del ingenio como bien se ha observado en este trabajo-, siempre y cuando se observe el arte $^{529}$.

El ingenio permite al poeta componer versos que no son ni humildes, ni medianos, siguiendo la interpretación que Jáuregui ofrece a los vv. 372-379 de la poética horaciana ${ }^{530}$. Por tanto, hay dos estilos que debe evitar el poeta: el puramente llano y aquel que solo consigue lo sublime ocasionalmente. En conclusión: "El ingenio poetico presuma estremados peligros, pero no pretenda alabança si se perdiere en ellos, que no le valdra por disculpa lo q[ue] a Faeton: Magnis tamen excidis ausis. pocas [sic] i leves pèrdidas se le permiten, gran constancia se le encomienda" (f. 19r). Al recurrir a uno de los mitos preferidos de las Metamorfosis (II, vv. 327-328) ${ }^{531}$ durante el Barroco, Jáuregui deja en claro que fallar intentando grandes proezas no es opción para el poeta y que, si bien se permiten "caidas, tropieços, o lapsos" (f. 19v), deben ser ocasionales.

La disertación continúa sobre la virtud de la igualdad -propio del estilo poético grandioso-y el vicio de la desigualdad -con sus constantes precipicios estilísticos-y las diferencias de ambos, entre las que destaca el trabajo que implica ora la virtud ora el vicio. De tal guisa, se lee en el Discvrso: "Para ultimo honor de la igualdad en los gra[n]des escritos, se considere que quien la consigue da muestras de infinito caudal i no menos trabaxo: i los desiguales la dan de floxedad i pobreza" (fols. 21r-v). El trabajo que requiere la igualdad es superior al de la desigualdad, como se nota en la prolífica y constante práctica que el poeta tiene que realizar para conseguir una obra con un estilo que mantenga constantemente la grandeza de sus locuciones. Así, Jáuregui, para una argūmentātı̆o que carece de testes -tal y como lo ha prometido el poeta-, recurre a una serie de preguntas retóricas:

Digan los que mejor escriben, quantos primores mal logran por no acompañarlos con desaires? Quantas composiciones mediadas perdieron sus principios bellissimos por no hallar iguales los fines? quantas [sic] casi acabadas se volvieron al yunque, i se aniquilaron, no pudiendo emendar en ellas pocos defetos? quantas [sic] galas de ingenio, sentencias briosas, frases bizarras se escluyeron de nuestra poesia, por huir la consonancia violenta, la voz humilde, la oracion equivoca, o algun tal desavio, que impedia la entereza del metro? (f. 21v)

El arte de esta poética discursiva no solo indica qué debe decirse, sino también qué debe callarse en aras de mantener la igualdad y también la "entereza del metro", elemento de gran importancia para la armonía y conseguir el deleite del oidor. El último se consigue, además, cuando

${ }^{529}$ En esto García Berrio observa un uso moderado del arte en el Discurso. El crítico afirma: “Juan de Jáuregui trataba de criticar los vicios del nuevo gusto culterano, proponía una razonable dosis de respeto a las normas del arte, del saber, como antídoto de las extravagancias en las que se puede despeñar el poderoso ingenio lego" (Introducción a la poética clasicista, p. 170).

${ }^{530}$ Como bien indica siempre el hispanista, García Berrio, el poeta pintor equipara su término de desigualdad con el de méd ̌̌ŏcritāas que usa el poeta latino (vid. op. cit., pp. 191-192). Jáuregui interpreta la excelencia que Horacio pide en los poetas con la carencia de los precipicios en el estilo poético, siempre tendente a una grandeza no vacua.

${ }^{531}$ Vid. J. de Jáuregui, Discurso poético, M. Romanos (ed.), p. 99, n. 5. 
el poeta se deshace en numerosas ocasiones de varios primores, entre los que destacan las "galas de ingenio". Opino que estos corresponden de forma general al ornāmentum creado gracias al ingenio, ya que no se especifica si se refiere a tropos u otros tipos de aderezos. En otras palabras, una vez más, Jáuregui enaltece la capacidad creadora de la causa eficiente de la poesía y deja en claro que la verba se crea con su gran fuerza, pero no se encarga de establecer que se excluye y qué no. Tal activad corresponde pues a la prudencia admirable y a otras características adquiridas -el stŭdŭum, por ejemplo.

A propósito del trabajo que requiere la virtud de la igualdad Jáuregui usa una peculiar metáfora de dos obreros que extraen oro de una mina: "el uno en massa purissima, i el otro en piedras o terrones sin beneficio" (f. 22r). Jáuregui equipara entonces al primero con el poeta moderno, porque no es posible traer tal cantidad de "massa purissima" de una mina a menos que recoja el trabajo de alguien más. Con base en esto, no

falta[n] pues al ingenio mas pobre minas de do[n]de saque metales, si nò en propia juridicion, en las agenas, imitando de otros autores: mas estos metales, aunque sean mui preciosos, no se precian nì se agradecen en piedra, ni embueltos en escorias, sino acrisolados i limpios: aquello alcançan los mas inabiles, i esto se concede solo a insignes artifices; i quando se halla, merece incomparable aprecio. (fols. 22r-v)

El Discvrso acusa a los modernos de una ı̆mĭtăť̆o servil y estéril, porque su ingenio es pobre e inhábil, incapaz de tomar aquellos metales preciosos, ya pulidos, e integrarlos a su obra que es "piedra" y "escoria". La falta de gran fuerza del ingenio hace al poeta caer en el vicio de la desigualdad, porque mientras toma de otros las "galas del ingenio", su estilo bajo será lo que predomine en la obra.

Pese a la importancia del ingenio poético creador, Jáuregui llama "insignes artifices" a quienes usan los metales preciosos de forma acrisolada y limpia. Me parece que el apelativo, aunado a la constante presencia de otras cualidades poéticas, indica que el artificio (arte) es necesario, como se observa durante la enmienda del texto, o bien "los primores últimos de la lima" (f. 22v). Es cierto que el fragmento alude a una cualidad de la agudeza y como esta se asocia a la perfección estilística a la que debe aspirar el poeta (vid. "Capítulo II"); sin embargo, me parece importante mencionarlo aquí por la auctōrĭtās que el poeta sevillano utiliza para su argūmentātǐo: la quinta elegía del libro primero de las Ěpistŭla ex Ponto $^{532}$ de Ovidio. Aquí se afirma que "Mayor trabajo es [...] emendar lo escrito, que escriuirlo, ni puede padecer el ingenio mas duro afan" (loc. cit.). Por lo tanto, el ingenio no solo se encarga de la creación poética, sino también de su proceso de enmienda. A lo largo de este estudio, Jáuregui es el primero que da al ingenio tal tarea, misma que, dentro de la poética discursiva, no es de ninguna manera menor. La reflexión además recuerda parcialmente los versos

${ }^{532}$ Otra ligera imprecisión por parte de Jáuregui, quien i. m. señala que es la "eleg. 6.", como anota Melchora Romanos (vid. J. de Jáuregui, Discurso poético, M. Romanos ed., p. 105, n. 19). 
horacianos (vv. 304-308) que conceptualizan el Arte como una piedra afilada, pero aquí es el ingenio quien posee esa cualidad.

Jáuregui continúa rescatando el carácter creativo del ingenio. Para esto, durante la pěrōrātǐo del cuarto capítulo, enfatiza en el carácter vacío de la verba moderna, la cual condena a los poetas al vicio de la desigualdad:

porque los afectados modernos casi siempre tropieçan i caen, i a veces con fracasos tan graves, que uno bastava a dexar sin vida un poema. esto [sic] sin subir a lo alto, sino a lo aspero, porque de milagro se encumbran. Ni sus altivezes aspiran a concetos de ingenio, sino a furor de palabras: en estas pretenden grandeza, i solo consiguen fiereza, interpolada con infimas indignidades. (fols. 23r-v)

Jáuregui contrapone el "furor de palabras" -"fracasos tan graves"- a los "concetos de ingenio", que recuerda claramente a otra contraposición hecha por Jáuregui entre el "vazio de las palabras" y los “co[n]cetos sublimes i arcanos". Por otra parte, es evidente que el furor al que se refiere aquí es al aliento primigenio que inflama al ingenio para que busque las grandes hazañas. Aunque, como ya ha señalado, dejarlo actuar por sí mismo es el error en el que porfían los modernos, por lo que crea palabras carentes de los "concetos de ingenio".

Mencioné más arriba las razones por las cuales estos conceptos aún no pueden ser relacionados con la agudeza como lo comentan Mercedes Blanco o Matas Caballero (vid. "Capítulo II"). No obstante, considero importante señalar aquí una vez más que comparto la lectura etimológica que hace Carreira de conceptos: "los concebidos". Asimismo, quiero enfatizar que el Discvrso es en parte una poética retoricada, por lo que me parece evidente la cualidad retórica de rēs: el cuerpo, como el mismo Jáuregui los llama en su "Introducion" a las Rimas ${ }^{533}$. Por lo tanto, estos conceptos de ingenio son producto precisamente de la gran fuerza creadora de la causa eficiente. Ahora bien, tal aspecto sí me parece que preludia lo que Gracián concebirá como una de las cuatro causas de la agudeza $a^{534}$. No obstante, no opino que estos sean para Jáuregui en sí conceptos ingeniosos y agudos, en un sentido gracianesco. Veo más bien al Discvrso como un puente entre la estética renacentista basada en la retórica clásica de la rēs y la estética barroca de la que parte y se nutre Agudeza y arte de ingenio.

${ }^{533}$ Vid. "Introducion", Rimas, s. f. Una connotación similar tiene en el capítulo quinto que trata de la importancia del contenido poético, puesto que el aspecto fonético no puede ser el único que sostenga la dignidad poética. Así, erran algunos versos que "previenen solo el oido al estrepito de las palabras, i si estas resuenan tremendas, ninguna otra cosa averiguan para apreciar lo escrito, creyendo verdaderamente que la poesia no es habla concertada $i$ conceto ingenioso, sino solo un sonido estupendo" (fol. 26v). En primer lugar, se alude a la oposición creada entre la rēs y la verba por la poesía moderna, y se reafirma respectivamente cómo se rompe o mantiene un decoro más cercano al carrillesco que al cascaliano. En segundo lugar, el concepto ingenioso -sintagma al singular- se refiere al cuerpo del poema lírico, siguiendo la convención a la que habían llegado las poéticas renacentistas, las cuales equiparaban la fábula épica al concepto lírico -hecho ya observado en las poéticas dialógicas.

${ }^{534}$ Vid. Emilio Hidalgo-Serna, “Origen y causas de la 'agudeza': necesaria revisión del 'conceptismo' español”, en Sebastián Neumeister (ed.), Actas del IX Congreso de la Asociación Internacional de Hispanistas, I, pp. 477-480. 
Una vez que el sevillano ha enunciado los engaños y vicios de la poesía moderna y explicado sus causas, en el capítulo quinto expone "Los daños que resultan, i por què modos" (f. 23v). Como ya se ha advertido en la poética desde la dedicatoria, los primeros se refieren principalmente a los hechos a la lengua. De tal manera, el poeta reformula sus argumentos - conservando el tono deliberativo de su obra- y afirma:

De tantos engaños i desordenes se sigue[n] ofensas graves a nuestra patria, i le[n]gua: porque presumiendo exornarla con copia de peregrinas galas, se introducen abusos i absurdos viciosissimos. juntamente [sic] se olvida el valiente exercicio i mas propio de los ingenios de España, que es emplearse en altos concetos, i en agudezas i sentencias maravillosas. (loc. cit.)

El poeta recurre al tópico del ingenio español y su superioridad, pero lo resignifica con el correcto ejercicio de los tres aspectos que corresponden al cuerpo y adornos de la poesía -siguiendo la terminología de Jáuregui. Este argumento además le permite justificar la ūtǐlĭtās de la poesía como portadora y conservadora de una lengua no solo gramaticalmente correcta, sino portadora también de agudezas que visten "altos concetos". En otras palabras, con la poesía se explotaba la lengua nacional y el ingenio español, sin que por esto se busque deformarlo con los excesos de palabras vacías, el vicio capital de la cacocelía.

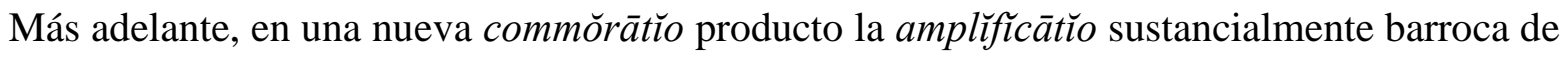
la poética, se condena la violencia que se hace al lenguaje, justificada con la búsqueda de la novedad. En consecuencia, se prescribe que "en infinitas osadias solo se lleve[n] a efeto las atinadas: i que dentro de nuestra le[n]gua propia, se fraguen elegancias peregrinas" (f. 24v). La novedad no es condenada siempre y cuando se eviten los extranjerismos que atentan contra la lengua y se respete moderadamente su lengua, con lo que se asegura la elegancia de las voces peregrinas.

En lo anterior recae la verdadera dificultad y dignidad poéticas, porque "a no ser necesario tan diestro ingenio, tan sazonada suficiencia de estudios, seria injusto el honor q[ue] diessemos a la poesia suprema" (f. 25r). El binomio ingenio y stūdŭum, que concentra parte del ideal poético de Jáuregui, es una vez más enfatizado en la poética para denotar, en esta ocasión, la superioridad de la poesía, representada en la elegancia: "Eficaz y grave compostúra de estílo, con que se expressan en la oración los conceptos, usando de términos proprios, puros y sin afectación" ${ }^{\$ 35}$. El poeta sevillano recurre a un término de la retórica clásica, encumbrado por la poética renacentista, para oponerse a lo que él considera los vicios de la poesía moderna: los excesos y la vacuidad de la verba.

A dicho estilo elegante ${ }^{536}$ se contrapone el "estilo tan facil, que quantos le siguen, le co[n]siguen. i [sic] au[n]que su primer instituto fue sublimar los versos i engrandezerlos; eligieronse

${ }^{535}$ Diccionario de la lengua castellana ..., s. $v$. estilo.

${ }^{536}$ La pěrōrātǐo del capítulo quinto se centra en la importancia del trabajo que el ingenio realiza para obtener la grandeza de la ēlǒcūtǐo, lo que dignifica a la poesía: "Cuesta ingenioso desvelo, hablar altamente sin corrupcion de la lengua, ni estorvo de la inteligencia: guiar el estilo con tal vigor i templança, que ni le derrotemos en perdidos pielagos, 
medios tan libertados, que mal logrando el intento, facilitan grandemente el estilo, i facilmente destruyen su altitud i grandeza" (f. 25r). Los sintagmas que Jáuregui contrapone entre sí para referirse a la buena y mala poesía varían en cada capítulo del Discvrso y, asimismo, las características del poeta ideal cambian un poco dentro del mismo semántico. No obstante, quiero resaltar cómo el ingenio en todo momento está presente, aunque casi siempre contenido ora por el arte, ora por el stŭdŭum, ora por la prudencia, ora por todos ${ }^{537}$. Las obras que contradigan esta balanza son reprochables y quien "juzga estas libertades por hazañas, i les atribuye algun merito" (loc. cit.) demuestra su ignorancia, aspecto que el poeta pintor trata a continuación y relaciona con el ingenio de los receptores.

Pese a que anteriormente ha atacado a los receptores que aprueban la poesía moderna, Jáuregui retoma su tono moderado y recurre otra vez a la captātǐo běněvǒlentǐae. Esto no le impide dejar de señalar las fallas del oidor o leyente usando varios lōci à persōna, porque no hay manera en que estos pecados poéticos no sean evidente para todos. De tal manera, es posible "que algunos, de amistad o respeto, o ya por cobardia de ingenio, den a entender que se agradan, pero es imposible que lo sienta[n]. i [sic] si el mas amigo i cortès o el mas cobarde quiere no esconder la verdad, hallaremos q[ue] todos sin ecepcion, sienten en lugar de recreo, aspereza i tormento" (f. 28v).

Son entonces tres las razones por las cuales se pueden juzgar placenteras dichas obras: dos por la relación que existe entre el así proclamado poeta y su receptor, y otra por la "cobardia de ingenio", que indica un defecto en su capacidad natural. La cobardía, el temor, "miedo, pusilanimidád" 538 que manifiesta el ingenio receptor se nota al momento de valorar el poema moderno. Se reafirma que para Jáuregui el ingenio posee una cualidad receptora que lo relaciona incluso al juicio, lo que no es de extrañar, porque una parte de la tradición hispana los ha asociado ${ }^{539}$, aunque no había ocurrido de esta forma en las otras poéticas del corpǔs.

ni demos con el en baxios cerca de tierra: que lo peregrino i estraño no se estrañe por peregrino; no atemorize con el escandalo, sino agrade con la novedad: que se distribuyan las vozes con tal industria, que halle el brio de la lengua facil expedicion i descanso al pronunciar los versos: i q[ue] dellos resulte tan artificiosa armonia, q[ue] no pueda pretender el oido mayor regalo" (fols. 30v-31r). Esta es la primera vez en que el ingenio es mencionado en solitario y se le adjudica la responsabilidad de la měd ̌̌orĭtās poética, la cual, sin dejar aspirar a la novedad, al vigor y al brío de la lengua, enaltece la templanza, la facilidad de pronunciación y, principalmente, la artificiosa armonía. El ingenio, causa eficiente, no solo concibe conceptos sublimes sino también el artificioso lenguaje poético con su "desvelo", es decir, con su trabajo infatigable, como ya recomendaba Ovidio a lo largo de su Е̌pistŭla.

${ }^{537}$ De esta manera, el "estilo tan facil" se vuelve también un "trage barato" con el que los poetas modernos "reducen la importancia i el ser de su poesia al desgarro i braveza de locuciones i vozes: barata gala: què ingenio sin caudal no querrà entrar en el uso?" (fol. 26v). La falta de bienes de este ingenio puede referirse a la ausencia de arte, stŭdŭum, prudencia e incluso aliento. La pobreza de este ingenio cono respecto al ingenio poético ideal de Jáuregui es lo que provoca el desprestigio y humilla un ejercicio tan digno como la poesía. En otras palabras, la poesía moderna vuelve nula la justificación de la poesía.

${ }^{538}$ Diccionario de la lengua castellana..., s. v. cobardía.

${ }^{539}$ Recuérdese a propósito de esto las observaciones hechas por Mercedes Blanco (vid. Les Rhétoriques de la Pointe, pp. 32-33). En este estudio, la hispanista también menciona someramente la relación entre el juicio y la prudencia, misma a la que Jáuregui recurre para sustentar su metáfora religiosa. 
Ahora bien, si el receptor aplaude este tipo de poesía y su aprobación no se debe a alguna de las razones enunciadas, lo hace porque en él prima la ignorancia plebeya. Jáuregui ofrece de esta forma una reinterpretación del tópico horaciano odi prophanum que además de ridiculizar el aplauso presumido por los poetas modernos, encumbra la importancia y necesidad del stŭdı̆um. Así, solo la “ciega plebe se alarga oi a llamar cultos los versos mas broncos i menos entendidos" (loc. cit.). De tal guisa, Jáuregui niega incluso al vulgo un ingenio pusilánime, pero no porque no posea ingenio, sino que este es justamente plebeyo, como se precisa en el siguiente capítulo del Discvrso.

Sobre el público de la poesía se ahonda en el capítulo seis de su poética, "La obscuridad, $i$ sus distinciones", en donde el sevillano explica que la aceptación de cierto público es el que ha permitido y propiciado la existencia de la poesía moderna. En el resto del texto, ha quedado bastante claro que la poesía moderna es un error -un pecado-; sin embargo, incluso así es aplaudida. Para probar que esto también es un error, Juan de Jáuregui recurre al ingenio como base de una refutación ăd hŏminem de dicho público.

Cierto es que los ingenios plebeyos, i los no capazes de alguna elega[n]cia, no pueden estender su juizio a la magestad poetica: ni ella podria ser clara a la vulgaridad, menos que despojada de las gallardias de su estilo; del brio i alteza de sus figuras i tropos; de sus concetos gra[n]des, i palabras mas nobles: circunstancias i adornos forçosos en la oracion magnifica. (f. $31 \mathrm{v}$ )

En este fragmento, ingenio funciona como metonimia de individuo -tópico de la época- y, gracias a las cualidades con las que Jáuregui lo ha dotado a lo largo de la poética, adquiere un mayor peso semántico. Así, el ingenio plebeyo denota no solo la pobreza intelectual de un receptor inadecuado, sino también su falta de stŭd̆̌um y juicio para calificar correctamente una obra poética. En otras palabras, el poeta anula totalmente el valor que pudiese tener las opiniones que este ingenio cree. Así pues, el adjetivo usado anteriormente para la ignorancia se extiende al ingenio mismo, volviéndolo plebeyo, incapacitado para comprender y juzgar correctamente la "magestad poetica", tanto en su causa material como formal. De esta forma, se reafirma y enuncia de nuevo el decoro prescrito entre los conceptos grandes -cuerpo poético- y el estilo gallardo y elegante -ornamento poético. Además, se especifica un tipo de público e ingenio, mismo que se contrapone al siguiente.

Ya en la cita anterior ("palabras mas nobles") y en el mismo adjetivo con el que se caracteriza en esta ocasión el tópico ōdi prŏfānum vulgus ět arcěo, se alude al ingenio que funge como contraparte del plebeyo. Como Carrillo, Jáuregui sabe que la poesía está designada para un grupo restringido: una aristocracia intelectual. Sin embargo, en el Discvrso no hay límites tan estrechos y considera a un grupo más amplio para comprender parcialmente la poesía, porque

para entender ilustres versos supongo por oyentes alomenos los buenos juizios, i alentados ingenios cortesanos, de sufie[n]te noticia i buen gusto; i sobre todo inclinados al arte; porq[ue] si carecen desta inclinacion, o la poesia les enfada; (como vemos en muchos) aunq[ue] sean 
mui doctos i sabios, son impropios oyentes; quanto los aficionados son digno teatro, aunque no lleguen a eruditos i doctos. (fols. 31v-32r)

En consecuencia, no solo los eruditos y doctos -como en el "Libro"- pueden acceder al arte poético, sino también aquellos "buenos juizios, i alentados ingenios cortesanos".

Jáuregui reinterpreta uno de los mayores ideales renacentistas: el cortesano, cuya capacidad con la lengua debía garantizar una conversación ingeniosa y elegante, para amenizar encuentros, que incluían la lectura en voz alta de poesía de clásicos u originales. Por ello, la comprensión e incluso la creación poética eran indispensables para enaltecer y reafirmar la nobleza ideal. De aquí que en el Discvrso se hable de un ingenio cortesano. No obstante, Jáuregui usa también este ideal como captātı̆o běněvŏlentĭae para los cortesanos a quienes dedica su poética y sus poemas. Como bien indica Mercedes Blanco ${ }^{540}$, Jáuregui fue un poeta de la corte del Conde de Olivares -a quien dirige el Discvrso- por lo que incluir a los ingenios cortesanos es además de conveniente, necesario. Por supuesto, el poeta sevillano argumenta su postura con una auctōrĭtās: Horacio, quien en sus Sátiras $(\mathrm{I}, \mathrm{x}, \mathrm{vv} .72-77)^{541}$ se refiere al équěs, la clase noble que patrocinaba entonces al poeta latino.

Antes de continuar, es importante evidenciar las características que deben poseer los ingenios cortesanos. En primer lugar, están acompañados del buen juicio; además, como el ingenio poético, también debe estar alentado -inflamado por el aliento-, ser observador, con buen gusto y, lo más importante, mostrar una clara inclinación al arte. El eco de esto último con la teoría huartiana afianza la línea teórica de la que se nutre y es continuador Jáuregui, la cual confirma la disposición natural del ingenio para la creación y recepción de la poesía. En otras palabras, el tópico de la naturaleza poética -se nace o se hace- se extiende claramente hacia el receptor con todas sus particularidades.

A lo anterior se aúna la grandeza del ingenio español-otro tópico-, cuya presencia explica por qué los poetas buscan nuevas formas de agradar a su público. El poeta sevillano entonces concede que estan oi los ingenios de España muy alentados, i que deve el que escrive alargarse a bizarrias superiores, porque muchos, no siendo poetas, no se espantan ya de los versos, ni rehusan leerlos con el temor i sumission que otro tiempo. antes [sic] ai muchos animosos que previenen advertencia i deseo, no pidiendo a las Musas la facilidad i llaneza que los incapazes pretenden, sino maravillas i estremos. (f. 32r)

Jáuregui vuelve a mencionar a ese público cortesano que "no siendo poetas" no temen acercarse a la poesía, primero por alcanzar el noble ideal del cortesano y, luego, porque su ingenio alentado se lo permite. Se establece así una dinámica entre el ingenio poético y el ingenio cortesano, puesto que el segundo es el que incentiva al primero a crear “bizarrias superiores". De cierta forma, el ingenio cortesano se convierte en un tipo de aliento terrenal, puesto que ya no son receptores pasivos y exigen

\footnotetext{
${ }^{540}$ Vid. Mercedes Blanco, “Introducción” para J. de Jáuregui, Discurso poético, M. Blanco (ed.), s. p.

${ }^{541}$ Vid. J. de Jáuregui, Discurso poético, M. Romanos (ed.), p. 126, n. 3.
} 
las "maravillas i estremos" de las Musas. De tal guisa, la llaneza -que ya había sido previamente censurada por Jáuregui- se consolida como una característica no grata de la poesía.

Por otra parte, al prescribir la distancia existente entre el estilo poético y el estilo llano, Jáuregui acepta también que la poesía pierda en parte su persp̌̌cŭt̆ās. En consecuencia, la búsqueda de grandeza que exige el ingenio cortesano permite "alargarse la oscuridad poetica, su grandeza digo i elegancia; que no es justo llamalla oscuridad, aunque se esconda a muchos; sus ingenios en tal caso son los oscuros" (f. 32r). A diferencia del "Libro", el Discvrso no hace la distinción entre dificultad y oscuridad; sin embargo, se mantiene el argumento de fondo: la poesía no es para todos y si resulta oscura es porque el ingenio del receptor lo es.

Asimismo, dicho ingenio no alcanza a comprender las grandezas poéticas porque la poesía tratada por Jáuregui es aquella de "estilo mayor" y no "una familiar Epistola, o senzilla Egloga, con otros infinitos asuntos medianos, piden diferente descuido, i claridad mas desnuda" (f. 32v). Nuevamente hay puntos de incidencia entre el "Libro" y el Discvrso, esta vez con respecto al corpŭs poético defendido en sus poéticas discursivas. Tal hecho muestra lo que muchos hispanistas ya han demostrado: la inexistencia de una tajante distinción entre culteranismo y conceptismo, e, incluso de la presencia de este último como escuela en la época. No es posible pues hablar de una poética culterana y una poética conceptista, como lo hizo en su momento Villanova.

Considero que lo anterior es aún más evidente en el tono moderado del Discvrso. Jáuregui mantiene en todo momento un sutil equilibrio, sin descuidar los dos aspectos de la balanza. De tal manera, recupera por un lado la dignidad y superioridad poética-resultado tanto de la inflamación del ingenio poético como del ingenio cortesano, igualmente alentando, que se lo exige--, con la que justifica su existencia, y reprueba por otro a los ingenios plebeyos y oscuros que la acusan de oscura. Todo esto sin olvidar que son esos mismos ingenios plebeyos los que han aceptado la poesía moderna, que no consigue la grandeza poética al depender únicamente del aliento primigenio y evitar arte, stŭd̆̌um y prudencia.

Esta distinción de estilos poéticos -en la que no se profundiza más en el Discvrso-permite a Jáuregui establecer primero una distinción de ingenios y, a su vez, una jerarquía que los acerca o aleja de la poesía que a él le concierte, la que posee un estilo mayor. Con base en esto, los ingenios cortesanos podrían llegar a entender la poesía, pero no "conocer sus meritos" (f. 32v), por lo que el poeta sevillano declara:

el intimo auditorio que para esto admito es superior a la plebe, es de ingenios alentados, que conocen nuestro le[n]guaje, i discurren con acierto en las materias, aunque no sean exercitados en letras: debido es que entienda estos el sentido a lo menos de los versos, si le tienen, bien que sigan estilo supremo. I quanto al aprecio de sus quilates, iuzgarà mejor el mejor gusto; conocerà mas el que mas sabe. (loc. cit.) 
Estos ingenios alentados no son los cortesanos antes mencionados. Me parece que con tal apelativo el sevillano se refiere a los humanistas españoles que poseían un conocimiento aún más profundo de la lengua y de las diferentes ciencias.

El stŭdŭum, por lo tanto, es fundamental para este tipo de público. Incluso el buen gusto depende de la educación que el individuo tenga; así, aunque el ingenio en cuestión no se empeñe en el quehacer poético -como el ingenio cortesano-, no afectará su comprensión del "estilo supremo". Considero pertinente evidenciar que, además del stŭdǔum -cualidad externa-, el aliento del ingenio también es esencial. Ambas son características que separaran al "intimo auditorio" de los ingenios plebeyos que no pueden de forma alguna entender el estilo mayor y menos aún comprender la dignidad del estilo supremo.

Ahora bien, contrario al estilo mayor, el estilo superior no es descrito por Jáuregui. Pese a esto, opino que ambos estilos se refieren al mismo ideal de estilo poético que trata durante toda su poética. Por tanto, lo que separaría ambos términos -mayor y superior- sería precisamente la capacidad del ingenio receptor. En otras palabras, el ingenio cortesano es capaz de identificar parte de su sentido (estilo mayor), mientras que el ingenio alentado puede develar incluso los conceptos sublimes en donde radica el estilo superior. Esto lo supongo a partir de la siguiente mención del ingenio, que clarifica una jerarquía que recuerda los grados de exegesis estipulados por Dante en su Epístola XIII y que relega una vez más en el ingenio del receptor su acercamiento al valor último de la poesía.

Para Jáuregui, aquellos individuos "de menor esfera se entretiene solo con lo inmediato i superficial: otros mas caudalosos conocen diversos motivos de estimacion: hasta que los mayores ingenios, los mas doctos i practicos en la facultad penetran al intimo compuesto, complaziendose màs q[ue] todos en lo superior de sus meritos" (f. 33r). El poeta sevillano no menciona literalmente a los ingenios plebeyos, cortesanos o alentados. Sin embargo, los primeros se aluden con la "menor esfera" y los otros son ingenios intermedios entre esta y los mayores ingenios que no solo conocen la lengua perfectamente y poseen amplios estudios, sino que son "doctos i practicos en la facultad", con lo que pueden llegar a los aspectos más significativos de la obra poética. Entonces, entre los ingenios alentados y los mayores se diferencian con la práctica de estos últimos, los cuales además no son estudiados, sino doctos, con lo que puede prescindir del aliento. El vínculo entre esto y la erudición poética carrillesca es bastante estrecho; no obstante, es con el último nivel de entendimiento presente en el Discvrso lo que permite una identificación entre ambas poéticas.

Jáuregui, con base en la poética de Escalígero ${ }^{542}$-una de sus auctōrītātes modernas-, afirma que "el primor de algunas no puede ser penetrado sino por entendimientos divinos, i q[ue] en estos 
excita aquel poeta maravilloso espa[n]to. añadase [sic] que para conocer quanto es Virgilio, no basta menos que otro Virgilio. No por esto se niega a infinitos que lea[n] al poeta, i le entiendan" (loc. cit.). En este caso se habla de entendimientos divinos y no de ingenios, aunque considero que se trata de un sinónimo que el poeta sevillano usa debido a que se explota la capacidad de comprensión entendimiento- del ingenio. Esto lo concibo a partir del mismo hipotexto de Jáuregui, los Poetices. El texto en latín usa el término "inguiniisque" 543 , que literalmente se lee "e ingenios"; por lo tanto, si Jáuregui lo traduce por entendimiento, significa que ambos términos pueden llegar a ser sinónimos en el Discrrso, al igual que ocurre en la obra de Vives y de una parte de la tradición ${ }^{544}$. Hecho que se observa aún hoy en la tercera acepción del DLE ${ }^{545}$.

El poeta de Sevilla, entonces, no considera en este caso el término ăd litteram, sino por su función, misma que a lo largo de su poética ha aludido constantemente, tanto para el ingenio poético como el receptor. La denotación había sido ya aludida en la Philosophia, pero no había adquirido este cariz de sinonimia. Como he insistido a lo largo del análisis, en todo momento las poéticas han distinguido características particulares de cada potencia humana, aunque lleguen a asociarse entre sí. Con Jáuregui, empero, la importancia de un ingenio que abarca cada aspecto poético permite no solamente la relación de contingencia con el entendimiento sino su sinonimia.

Así pues, este entendimiento-ingenio divino es el que puede aspirar a conocer en su totalidad la poesía creada igualmente por un ingenio divino como el de Virgilio. En las palabras de Jáuregui resuena el principio carrillesco de "solo el poeta puede juzgarse a sí mismo" 546 , pero inmediatamente abre las posibilidades y evita esta cerrazón intelectual: "No por esto se niega a infinitos que lea[n] al poeta, i le entiendan". El poeta de la corte de Olivares sabe que depende del mecenazgo para continuar con su producción. Asimismo, de esta forma se asegura que más personas se acerquen a su obra y pueda garantizar la $\mathrm{fama}^{547}$.

La posibilidad de establecer este vínculo de sinonimia entre ingenio y entendimiento obedece entonces a la función que Jáuregui privilegia en esta capacidad humana en los individuos que reciben y juzgan la obra poética. Además, esta gradación entre los ingenios del receptor-alentado cortesano, solo alentado, mayor y entendimiento divino- responde a la presencia y consideración del aliento. Si se nota en los primeros ingenios la cualidad de lo alentado aparece, mientras que tal característica

${ }^{543}$ Vid. J. de Jáuregui, Discurso poético, M. Blanco (ed.), n. 375, s. p.

544 Vid. Francisco Calero, "Ingenioso e ingenio en el Quijote", eHumanista, 30 (2015), 139-146 passim (disponible en línea: https://dialnet.unirioja.es/descarga/articulo/5473872.pdf).

${ }^{545}$ Vid. Diccionario de la lengua española, $s . v$. ingenio (disponible en línea: https://dle.rae.es/ingenio?m=form).

546 Sobre este principio hace hincapié cuando asegura que "Estos estremos del arte son los que mui pocos penetran, i si es superior el artifice, nadie los conocerà enteramente" (fol. 34r). Gracias a los diferentes grados de interpretación e ingenio propuesto por Jáuregui es posible llegar a este ápice en donde únicamente "Virgilio entiende a Virgilio" e ir descendiendo poco a poco por los ingenios alentados y cortesanos sin que se pierda en consecuencia la divinidad y dignidad poética.

${ }^{547}$ Vid. J. de Jáuregui, Discurso poético, M. Blanco (ed.), n. 373, s. p. 
desaparece en el ingenio mayor y se diviniza con el entendimiento. Esto es fundamental para la siguiente advertencia del poeta sevillano, puesto que, de la misma forma que hay poetas que solo se dejan llevar por el aliento para la creación poética, una parte del público depende de su ingenio para comprender, conduciéndolo a errores. En consecuencia:

hombres de tan claro ingenio, i tanta viveza en el gusto, aunque sin estudios; que guiados solo de su natural, aciertan a agradarse mas de la mejor poesia, i menos de la inferior, bien que no averiguan razones desta ventaja, ni sabe[n] los medios por do[n]de se adquiere. Pero estos, ni otros q[ue] mas sepa[n], (digase todo) no an de exceder el limite d[e] su juicio, sino creer fielmente, que algunas vivezas de particular energia, siendo inutiles i aun desabridas al gusto del mas presumido; seràn de admirable recreo para superiores espiritus. Es injusticia ala de algunos, que fiados en su buen ingenio quieren que todo se ajuste a medida de su entendimiento. Devieran antes alentar el discurso i estudio, i crecer en si mismos, para que les agradasse del todo la obra excelente. (fols. 35r-v)

El papel del stŭd̆um se enaltece en este punto, porque se específica que el individuo puede poseer claro ingenio y viveza en el gusto, pero "sin estudios" puede caer en dos errores. No es suficiente que la capacidad receptora sea adecuada y permita conocer la obra poética sin obstáculos -lo que se garantiza por su cualidad de claridad. El individuo además de desconocer las razones de su superioridad natural y buscar cultivarla, erra en su juicio ya que no puede superarlo, aún y cuando disfruta más la poesía superior que la inferior. La ausencia de stŭd̆̌um -o la poca dedicación a estele impide valorar correctamente "algunas vivezas de particular energia", mismas a las que ni el buen ingenio ni el gusto pueden acceder sin ayuda de esta dedicación intelectual.

En suma, el stŭdŭum -como ya se ha establecido a lo largo de la poética- es la herramienta que permite crecer a los individuos -“crecer en si mismos"-, superar su juicio natural y no despreciar aspectos de la obra excelente al pretender someterla a la autoridad de su entendimiento. Solo así podrá apreciar la poesía con causa en su totalidad y comprender el porqué. Aquí, claro y buen ingenio, viveza de gusto, juicio y entendimiento se asocian como cualidades inherentes que ayudan a discriminar correctamente entre la poesía superior de la mediocre, sin llegar a una complementación que las vuelva sinónimos entre sí como ocurrió en el caso anterior. Sin embargo, en la base tanto del juicio como del entendimiento se encuentra este ingenio que naturalmente es superior al resto, lo que no lo exime del stŭd̆̌um. De esta manera, siguiendo la ars rhētŏrĭca latina, se asegura que tanto el poeta como el receptor trabajen y se esfuercen en el arte que junto al ingenio subliman la obra del poeta. Tal cualidad exige que esta no sea banalmente contemplada, sino entendida primero, conocida en sus méritos después y finalmente penetrada en su totalidad.

Como cabe suponer, la jerarquía interpretativa propuesta en el Discvrso aplica únicamente a la poesía excelente. Por el contrario, las composiciones de la poesía moderna, a menos que se den los casos ya expuestos, "no solo se esconden i disgustan al vulgo, i a los medianos juizios; no solo los claros ingenios, i a los eruditos i doctos en otras ciencias; sino a los poetas legitimos, màs doctos, màs 
artifices, mas versados en su facultad, i en la inteligencia i noticia de todas poesias en diversas lenguas" (f. 36r). Si no se consideran al vulgo y a los "medianos juizios" -agregados para ridiculizar a la poesía moderna-, en esta ènŭměrātı̌o ascendente de los diferentes tipos de públicos se observan otra vez las características propias tanto del poeta como de la obra poética prescritos por Jáuregui y que siguen de cerca el modelo clásico y la poética renacentista ${ }^{548}$.

De la misma forma, en este orden ascendente, observo que los ingenios claros son colocados en primer lugar después de los medianos juicios, porque es la capacidad humana básica tanto para la producción como para la recepción de poesía. Reitero que la causa eficiente se perfecciona con el stŭdŭum hasta llegar al poeta legítimo. Este, además, tampoco puede develar la poesía moderna, no por falta de ingenio, arte o stŭd̆̌um, sino porque "au[n] no merece su habla en muchos lugares no[m]bre d[e] oscuridad sino d[e] la misma nada". Este "furor del le[n]guaje" (loc. cit.) es verba sin rēs, por lo que incluso al claro ingenio se le niega que penetre en ella, en la "nada". La poética discursiva de Jáuregui puede tener un tono moderado, que suaviza la agresividad de la diatriba en contra de Góngora en el Antídoto, pero su juicio no deja en ningún momento de ser enfático y determinante para estos que él llama modernos.

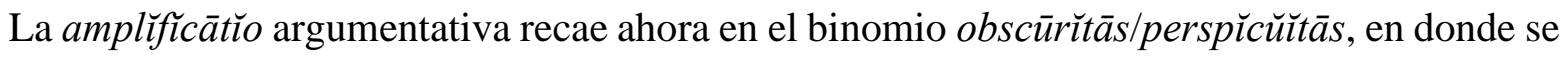
repudia la primera para enaltecer la segunda. Como parte de su commŏrātı̆o, el poeta sevillano aborrece a los oscuros porque no cumplen con la causa final de la poesía: el dèlectāre-identificado con el mŏvêre-, fin que antepone al dŏcēre como consecuencia de la vertiente hedonista a la que pertenece. De tal manera, la poesía en "deleitar principalme[n]se se sublima i distingue de las otras co[m]posiciones" (f. 37v). En otras palabras, otra característica distintiva de la poesía, aquello que también justifica y dignifica tanto su producción como a su artífice, es el dēlectāre como causa final y la poesía moderna no la consigue pues desagrada - y no poco- a quien la escuche o lea, como se ha dicho desde el primer folio.

Por otra parte, Jáuregui, como Carvallo, acepta la ütŭlittās poética entendida en el dǒcēre, enseñanza y provecho, y se la niega también a la poesía moderna. Pregunta retóricamente el poeta: ¿qué "provecho (quando a essa parte se atengan) si por su locucion no perspicua, esconden lo mismo q[ue] dizen?" (loc. cit.). Como ejemplo da a las proposiciones teológicas, las cuales son “importa[n]tes a nuestra Fè, si se escriben oscuras, rehuye[n] los mas doctos leerlas por no molestar el ingenio; qua[n]to menos se padecera essa molestia por entender los versos, au[n] qua[n]do se

${ }^{548}$ Jorge Zepeda, con base en el estudio de Rico García y de su propia lectura del Antídoto, asegura que Jáuregui posee una visión clasicista del oficio poético en tanto se basa en la inspiración poética para conseguir una expresión sublime que lo aleja del vulgo (vid. "Clasicismo, estética, tradición: el Orfeo de Juan de Jáuregui”, NRFH, LXVI, no. 2 (2016), p. 529). Esta misma concepción se mantiene en el Discvrso, como se ha demostrado ampliamente; sin embargo, considero que Jáuregui también es clasicista por el arte y stŭdŭum que deben guiar la inspiración divina, aspecto también anotado prolijamente y que responde asimismo a preceptos clásicos, especialmente de corte latino. 
esperasse hallar en ellos sentencias vtiles?" (loc. cit.). El ingenio es tomado aquí nuevamente por sinónimo de entendimiento, al que no se desea molestar con una verba confusa y banal, aún y cuando esta guarde conceptos tan importantes y altos como los religiosos.

Jáuregui pertenece a una tradición que propugna por la claridad ${ }^{549}$. Sus raíces están en el capítulo 22 de la Poética de Aristóteles y tiene como referencia fundamental las Instituciones oratorias (VIII, 2) de Quintiliano. En esta tradición clásica prevalece el entendimiento como la capacidad que aspira a la persp̌čŭtās. En contraste, el sevillano, fiel a su propia teoría poética, lo atribuye a la capacidad receptiva del ingenio, misma que siempre debe ser acompañada por el stŭd̆̌um y el arte, pero que, sin lugar a duda, es el origen de la creación poética y del placer estético.

Al final del Discvrso, se reconoce y explota precisamente la cualidad creadora del ingenio, misma que por translātǐo distingue aquellos ornamentos que crea, hecho que los modernos aprovechan y falazmente intentan "Ve[n]dernos la oscuridad por estudiosa i difícil" (f. 40r). Para Jáuregui, esta es una astucia con la se pueden engañar a los "oyentes senzillos" y que consiguen cuando el poeta moderno "vaptiza la ignorancia i pereza con titulo de diligencia e industria; i con vilissimos velos de locucion no solo encubre defetos y culpas, sino da a creer al simple, que son todas ingeniosidades" (loc. cit.). Es decir, el engaño reside en usar un disfraz superficial de la èlŏcūtĭo verba vacía- y hacerlo pasar por ingeniosidades: figurae - verba- que recubre conceptos sublimes rēs-, a los que se llega por medio del ingenio inflamado, supervisado por la prudencia y auxiliado por el stŭdüum y el arte, como ya se sabe.

El poeta autoriza y explica esta observación parafraseando al predicador Jerónimo de Florencia ${ }^{550}$ : "No es creible [...] que quien concibe hermosos concetos dexe de emplear gran cuidado, i poner mayor gusto en declararlos, por lo que interessa el ingenio en lograr bie[n] sus partos" (loc. cit.). El decoro entre rēs y verba es conseguido a través de la fuerza creadora del ingenio, pues este encuentra los altos conceptos y da la forma adecuada para “declararlos" - 'aclararlos'- por medio de una èlǒcūtǐo poética que, sin dejar de sublimar su contenido con artificio, los evidencia, delectando el ingenio del receptor. No quiero dejar de mencionar a propósito de esto que, tres décadas más tarde, Emanuele Tesauro usará una variante de esta afirmación para referirse a su argutezza: "Vn diun Parto dell’Ingegno" 551 . Por supuesto, no quiero inferir que Jáuregui se refiera indirectamente aquí a la agudeza, por las cuestiones ya comentadas (vid. "Capítulo II”), pero sí encuentro una línea de

\footnotetext{
${ }^{549}$ Esta ha sido identificada por Aurora Egido bajo el estatuto de limitar el ornato (vid. "La hidra bocal", pp. 100-107).

${ }^{550}$ Sobre la importancia de Jerónimo de Florencia como predicador en la corte de España vid. J. de Jáuregui, Discurso poético, M. Blanco (ed.), n. 417, s. p.

${ }^{551}$ Il cannocchiale aristotelico o sia Idea dell'arguta et ingegnosa elocutione che serve à tutta l'arte oratoria, lapidaria, et simbolica. Esaminata co' principii del divino Aristotele, p. 1.
} 
pensamiento que nutrirá a los dos grandes tratados europeos que disertaron sobre la agudeza en la segunda mitad del siglo XVII en España e Italia.

Para reafirmar lo anterior, la última mención del ingenio en el Discvrso, que trata una vez más de los engaños de los poetas modernos, demuestra el tipo de "partos" a los que no debe aspirar el poeta. Afirma el sevillano: "La locucion oscura es capa de inora[n]tes (lo mismo q[ue] de pecadores) ${ }^{552}$ i ta[n] barata capa, que el mas pobre ingenio possee abundatisimo paño para vestirse della" (fols. 40r-v). Se resuelve así que las ingeniosidades y los partos del ingenio se refieren precisamente a las locuciones que el poeta emplea para expresar sus conceptos y que dependen de la fertilidad o pobreza del ingenio. Es evidente que el Discvrso, como ya ocurrió con el “Libro", esboza lo que se conocerá como agudeza verbal y, aún más, con la agudeza de artificio, puesto que la relación tan estrecha que Jáuregui ha establecido entre rēs/verba, impide considerar a la ēlǒcūtĭo independientemente de su contenido.

Antes de concluir, me parece oportuno reiterar que no se pueden ni deben identificar las ingeniosidades aquí tratadas con las agudezas de Gracián, pese al enaltecimiento del estilo poético teorizado en el Discvrso. En principio, Jáuregui da un papel marginal al mismo término de agudeza y luego porque el concepto del poeta sevillano es sustancialmente diferente al del jesuita. La relación entre ambas teorías, si acaso, se encuentra en cómo la fuerza creadora del ingenio -en estas últimas menciones ya concebida únicamente en sí misma, sin depender del stŭdĭum u otro- es la causa eficiente de lo que cada uno de ellos entendía por concepto.

A lo largo de este análisis, he demostrado la importancia que el ingenio tiene en el Discvrso ya que se explota tanto su capacidad para inflamarse y crear, como su cualidad receptora -a veces matizada con funciones propias del juicio. Esto permite que tales características no sean solo observadas en el ingenio poético, sino también en el del receptor, mismo en donde la relación ingenioentendimiento alcanza su mayor manifestación y desarrollo, al grado de identificarse el uno con el otro. Asimismo, en el ingenio del receptor se explota la gran fuerza creadora del ingenio que se extiende a la creación de juicios a propósito de las obras poéticas y que depende de una tipología y jerarquización de ingenios, lo que he observado también en las diferentes poéticas estudiadas en este trabajo, dialógicas o discursivas.

Otro aspecto relevante del Discvrso es cómo el constante enaltecimiento del ingenio se cristaliza en que dicha fuerza - causa eficiente- se implica en la creación de la rēs y verba-causa material y eficiente-, cuyo decoro sublima y perfecciona el quehacer poético. Por supuesto, el

${ }^{552}$ Es bastante significativo que Jáuregui remate su poética y acusaciones con el testimonio de un predicador y con su metáfora religiosa, en ambos momentos asociado con el ingenio, capacidad natural que además de procurar la creación y deleite poético, parece propiciar el pecado al ser pobre o mal empleado. Gracias a la anfibología, el ingenio puede tener también una interpretación ética, como ocurre en la poética de Carvallo, aunque tal matiz en el Discvrso no es particularmente desarrollado. 
stŭd̆̌um, el arte y la prudencia acompañan en diferentes momentos y forma el proceso poético para conseguir el ideal poético de Jáuregui. Sin embargo, es indiscutible que a la base de esto se encuentra el ingenio poético, que -ora más limitado ora más libre- recorre los folios de una poética discursiva cuyo tono conciliador la coloca como puente entre la estética renacentista y la barroca. 


\section{CONCLUSIONES}

Para comenzar con mis reflexiones finales, me parece necesario recordar una vez más la deuda que la crítica tiene con el corpŭs que estudié. Sin desear profundizar en este aspecto, es evidente que los prejuicios que se han tenido al momento de revisar las poéticas han provocado descuidos, generalizaciones terminológicas e imprecisiones que he anotado en su momento. Esto ocurre, además, porque aún hoy desconocemos los métodos de recepción, producción y transmisión de dicho corpŭs. Estrategias literarias que no solo comparten entre sí, sino que reflejan cómo se leía y se producía en los Siglos de Oro. Las poéticas no son entonces completamente ajenas a la producción poética, no en tanto hayan fungido como manuales de escritura, sino que comparten un humus cultural, como mencioné en el "Capítulo I". En consecuencia, las connotaciones que López Pinciano, Alfonso de Carvallo, Cascales, Carrillo y Sotomayor y Jáuregui dan a agudeza e ingenio coinciden, de la misma manera que pueden o no hacerlo los poetas, novelistas y dramaturgos de la época.

Sin embargo, así como las connotaciones coinciden, también se separan porque, por ejemplo, Pinciano y Cascales comentan a Aristóteles. No obstante, el primero leyó seguramente una edición en griego y el segundo una en latín con eruditas glosas que recuperaban auctoritates grecorromanas o italianas. La interpretación de un mismo pasaje puede derivar en dos interpretaciones diferentes. De la misma forma, un mismo término, agudeza o ingenio, puede denotar una capacidad o cualidad en general, pero las connotaciones dependen en gran medida de la interpretación que cada autor da a su complejo entramado ecléctico.

Ahora bien, mi objetivo al iniciar esta investigación era conocer de qué manera fueron teorizados agudeza e ingenio en cinco poéticas de los Siglos de Oro antes de 1648, año parteaguas para los estudios de dichos términos. Ahora, a la luz de las interpretaciones que he ofrecido en este trabajo, puedo afirmar que en el corpŭs no existe una teorización explícita sobre agudeza o ingenio, sino una serie de connotaciones implícitas y explícitas que demuestran tanto la riqueza de los términos como de las teorías poéticas a caballo entre los siglos XVI y XVII. Así pues, quiero rescatar a continuación los diferentes matices de estas connotaciones. De tal manera, quien se acerque a las poéticas y a las obras de los Siglos de Oro poseerá una paleta más completa para interpretar los sutiles colores que hallará en ellas.

En primer lugar, los cinco autores denotan agudeza como una característica "puntiaguda", siguiendo la etimología de la palabra acutus. A partir de esta, señalé que la "metáfora de la punta" propuesta por Rodríguez Beltrán es operativa para el presente estudio, siempre y cuando se matice, porque cada poética desarrolla y explota de diferente manera lo "puntiagudo" de la agudeza. De hecho, esta capacidad "punzante" es visible incluso en aspectos formales de métricas teorizados por Pinciano, Carvallo y Cascales. La metáfora en este caso se traslada al ámbito sonoro y las sílabas 
agudas "penetran" en el aire y en el oído del receptor. Esto, a su vez, ofrece al poeta licencias poéticas, determinantes principalmente en las Tablas para la escansión de versos.

Otra connotación que tienen en común las poéticas dialógicas es la clara tendencia a relacionarla principalmente con la brěvitās y el epigrama, género agudo por excelencia desde la tradición grecolatina. Como consecuencia, la agudeza implica ya una cierta complejidad en sí misma, porque la brěvitās observada en el epigrama -u otro género breve como el refrán o el emblema en Pinciano o el villancico en Carvallo o el soneto en Cascales- conllevan una obscūrĭtās, al decir con pocas palabras más de lo que se quiere. Sobre este aspecto, Pinciano no profundiza, pero Carvallo y

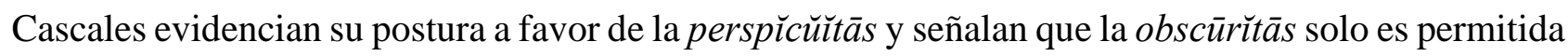
para motivar al receptor y debe ser aclarada.

La relación agudeza-brěvitās también la encontré en los conceptos -Pinciano-, dichos Pinciano y Carvallo-, sentencias y frases -Cascales. Cada uno de estos es calificado por los humanistas españoles como agudos y se caracterizan asimismo por ser una frase breve que encierra una idea o saber universal. Se encuentran entonces en el ámbito de la rēs poética, intrínsecamente relacionados con lo que Huarte de San Juan conocía como verbum mentis. En otras palabras, son una idea que puede ser 'observada' en una frase y que origina un epigrama, un villancico o un soneto, géneros breves y menores.

Con base en lo anterior, observo primero que la agudeza puede referir únicamente la "punta" -una parte- del concepto - rēs- expuesto por un género como el epigrama. Además, gracias a esta capacidad, incluso una poética clasicista como las Tablas acepta un tipo de obscūrîtās porque la brěvitāas "punza" el ánimo del receptor y lo motiva. Entonces, como expliqué con Carvallo, se vuelve una obscūrĭtās que propicia el dŏcēre ĕt dēlectāre, las posibles causas finales de la poesía en las tres poéticas dialógicas del corpŭs.

Por otra parte, anoté que los conceptos, dichos, sentencias y frases que son agudos o poseen dicha cualidad hacen referencia a la rēs pero tienen diferentes connotaciones dependiendo de cada poética. Así, en la Philosophia los conceptos y dichos agudos implican cierta comicidad. Esta naturaleza se la da peculiarmente una cuestión social, pues solo quien padece necesidad puede hablar de esta forma. Por el contrario, los reyes y príncipes hablan de forma llana y clara.

La cuestión, además de reiterar la complejidad propia de la agudeza, indica los géneros en donde decorosamente se pueden usar estos conceptos y dichos: aquellos del mědǐocrĭs y hŭmŭlis styli. Los géneros como la épica o la tragedia, que tratan sobre esos reyes y príncipes sin las necesidades propias del vulgo o de aquellos inmediatamente debajo suyo, parece que no pueden incluir conceptos y dichos agudos. Y digo parece porque, como es frecuente en poéticas que no teorizan sobre este término, no hay una conclusión final al respecto. De hecho, López Pinciano es el único de los autores 
del corpŭs que sugiere la posible presencia de estos conceptos y dichos en el grăvis stylus porque son agradables. La agudeza entonces deleita.

El carácter social del término es también señalado en las Tablas. Cascales, empero, no indica que se trate de un recurso que nazca de la necesidad. Él no ahonda mucho en las sentencias agudas como tampoco en las frases moratas, en cuyas características está la agudeza. No obstante, principalmente a partir de estas últimas, puedo inferir que en la reflexión del murciano existe una cuestión de èthŏs. Esto lo confirmo con la enumeración de características generales que poseen los personajes cómicos, entre los cuales se enlistan las diferentes nacionalidades y a los sicilianos se les llama agudos. Cascales sigue una tradición para esto, pero sin duda es una capacidad que distingue hábitos y comportamientos, los cuales, quiero enfatizar, no están presentes en caracteres propios de los grăvis stylus.

La crítica ha considerado las Tablas como el paradigma de las poéticas serviles y dependientes de las poéticas italianas. La deuda que la obra tiene con esta tradición es evidente, pero la forma en la que el profesor de latín entreteje sus hipotextos y los conduce a sus propias opiniones ofrece reflexiones particulares. De esta forma, es la única poética que considera la existencia de un soneto agudo -siempre a partir de la brěvitās-y, más notable, una agudeza que también puede implicar "limar" el estilo a partir de la ı̌mütātĭo ecléctica - retractio- de los ingenios clásicos. Considero que esta última connotación, aunque brevemente señalada en el apartado de la comedia, es muy valiosa para el desarrollo del término y más si se le compara con lo que ocurre en las poéticas discursivas, que comentaré en un momento.

En el Cisne las consideraciones sobre el estilo propio de la agudeza se aproximan más a Cascales que a Pinciano, ya que no sugiere su presencia en los géneros graves. Los dichos agudos se restringen a aquellos villancicos cercanos a tema populares y profanos. Así que, por lo general, la agudeza se relaciona con los géneros cómicos y menores. No obstante, como el murciano, Carvallo ofrece una propuesta bastante interesante sobre la agudeza.

Apunté que el Cisne es una poética dialógica que se caracteriza por su carácter moral y religioso. Carvallo al cristianizar sus fuentes y referencias clásicas relaciona a los poetas con los profetas cristianos, pues de esta manera reafirma el carácter divino de la poesía y su ütǔlĭtās. El poeta divino de Carvallo inmortaliza -afama- y enseña aspectos morales y positivos para la República. Para conseguir ambos objetivos, el poeta ideal del Cisne echa mano de su particular ingenio. Con base en la teoría de Huarte, el jesuita afirma que el ingenio sufre un complejo proceso de "divinización" que lo hace agudo, sutil y delgado, características que indican cómo dicho ingenio poético se "afila".

El Cisne es una de las dos poéticas de mi corpŭs que acerca el término agudo a lo sutil y lo hace para referirse a una capacidad natural ya "afilada" con elementos externos. La otra poética que 
hace esta relación es el "Libro" y también tiene una connotación similar. Sin embargo, quiero ahora solo enfocarme en que la poética dialógica señala que el elemento externo que "afila" es de carácter divino e irracional: el furor. Gracias a esto, la capacidad aguda-el ingenio- puede incluso discernir entre el bien y el mal

Respetando las particularidades de cada poética dialógica, existe otro elemento que tienen en común y que ya se puede percibir en el ingenio agudo de Carvallo. En el corpŭs es común que en las poéticas dialógicas a algunos de los interlocutores se les llame agudos o alguien que estos mencionen. De manera similar, en las poéticas discursivas, Carrillo y Jáuregui llaman a alguno de sus autores clásicos -sus auctoritaes-agudo. En ambos tipos de poéticas se señala así el individuo que juzga correctamente su realidad o bien las obras que escucha o lee. Es evidente que la función adjetival de estas menciones recae en el sujeto al que se le califica con el término agudeza. Sin embargo, como señalé desde el inicio, los autores recurren en la mayoría de los casos a una elipsis y, aunque se sigue calificando al sujeto, en realidad su función recae en una capacidad de este último. Ahora bien, inferí que las capacidades que pueden ser agudas son el ingenio o el entendimiento, dependiendo del papel que tuviese cada uno de estos en la poética.

La agudeza está señalando una característica de la capacidad que percibe; es decir, califica cómo se "penetra" en la realidad y en las obras. Por esto, el portugués al que se refiere Pinciano puede ver más allá de lo evidente y crear relaciones entre dos términos; el poeta divino de Carvallo puede acercarse a la divinidad; Pierio puede comprender las enseñanzas de Castalio y anotar inconsistencias en ellas. Esto, en cuanto a las poéticas dialógicas, mientras en las discursivas ocurre algo semánticamente similar y en cuyas particularidades ahondaré a continuación.

Señalé que en las poéticas dialógicas la agudeza tiene una estrecha relación con la rēs. Ahora bien, este es el punto de inflexión entre esta parte del corpŭs y las poéticas discursivas. Como anoté, el objetivo tanto del "Libro" como del Discvrso es la defensa y prescripción de un determinado tipo de poética y no de la poesía en general. De tal guisa, la agudeza pasa de señalar únicamente aspectos relacionados con la rēs -la causa material- a implicar también aquellos que tratan de la verba -la causa eficiente. No obstante, es innegable el peso de esta última en las poéticas discursivas, pues en la ēlǒcūtĭo se juegan las principales connotaciones que la agudeza tienen para Carrillo y Jáuregui. Sin embargo, pese a esta relación, es notable que la atención e importancia que el término tiene para cada uno de ellos cambia sustancialmente por la concepción que tinen de poesía.

En mis lecturas observé que en el "Libro" la agudeza posee una importancia capital en el estilo poético que privilegia Carrillo. Este aspira a una poesía erudita, la cual requiere que el poeta "afile"

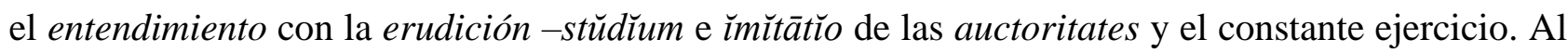
hacerlo, el poeta "lima" también el estilo y lo vuelve culto. Asimismo, el entendimiento agudo puede 
ir más allá de la realidad inmediata y acercarse en consecuencia a conceptos - rēs- cercanos a la divinidad.

Anticipé que el Cisne y el "Libro" poseen un punto de unión por la connotación que dan a agudeza al volverla adjetivo de una capacidad humana natural. Siguiendo este encuentro -producto de la tradición hedonística de la cual parten-, es oportuno anotar la manera en la cual se bifurcan los caminos. El ingenio agudo es semejante al entendimiento agudo porque su cualidad "afilada" les permite acceder a verdades cercanas a la divinidad, con lo cual alejan al poeta de la vulgar y común percepción humana.

Por otra parte, el adjetivo se le da al ingenio o entendimiento una vez que han sido afectados por un elemento o hábito: en el Cisne es el furor y en el "Libro" la erudición. Aquí radica la diferencia y es esencial. Ambas son causas externas al individuo, pero la de la poética dialógica es prácticamente una gracia divina, ajena a cualquier actividad humana. Contrario a esto, la causa de la poética discursiva se debe al esfuerzo del poeta. Él mismo con el stŭd̆̌um "afila" su entendimiento y se acerca a la divinidad. Carrillo racionaliza el proceso poético, alejándose de forma importante de la tradición. Su propia disciplina, formación y práctica poética le permiten comprender y exponer humanamente cómo ganarse el favor de las musas.

Sin embargo, esta racionalización no vuelve mundana la poesía erudita, todo lo contrario. Para Carrillo, el poeta es un individuo privilegiado, cuya profunda erudición le permite imitar la agudeza -la forma de "limar"- de sus auctoritates, aquello que el cuatralbo conoce como "buenas letras". Tal capacidad se nota en el estilo "limado" del erudito poeta, porque su entendimiento agudo ha determinado la dispǒš̆ť̆o de su obra que incluye a las agudezas: las figurae élŏcūtı̌onis. Estas, como armas "afiladas", defienden al poeta erudito del indocto que juzga su poesía sin autoridad alguna.

La poética de la erudición de Carrillo y Sotomayor consiste entonces en una poesía erudita de carácter elitista. Únicamente quien posea la misma erudición del poeta puede "penetrar" en los misterios de su obra con su agudo entendimiento. Esto porque el "Libro" especifica que la dificultad poética -mas no obscūrĭtās - es obligatoria en este tipo de poesía. En otras palabras, es inadmisible que la poesía erudita sea entendida por indoctos, con lo que se cuida el carácter elitista y casi divino de la poesía.

La última poética del corpŭs, el Discvrso, tiene aspectos formales en común con el "Libro" de Carrillo, de ahí que las haya colocado bajo el rubro de "discursivas". Además, también se basa en la êlŏcūtǐo. Sin embargo, su principal distinción está en que el "Libro" defiende un tipo de poesía y el Discvrso demerita aquello que llama poesía moderna. Es bastante probable que este principio 
ocasione las esenciales diferencias entre ambas poéticas tanto en el tratamiento que se le da a la agudeza como al ingenio.

Así, dentro el corpŭs que analicé, el Discvrso tiene el menor número de menciones -solamente cuatro- del término agudeza. No obstante, aún en el poco espacio que le dedica, en la mitad de dichas menciones se mantiene la connotación "puntiaguda" en tanto cualidad de una capacidad humana que "penetra" - en este caso- en las obras de los modernos para anotar sus vicios. Como ocurre en la Philosophia y en las Tablas, en la poética discursiva no se dice claramente de qué capacidad se trata, pero por la importancia y connotaciones que tiene en el Discvrso, intuyo que es el ingenio. No se dice cómo este se agudiza -como tampoco lo dicen Pinciano y Cascales-, pero su capacidad de percibir el mundo es superior y aleja del vulgo al individuo que lo posea.

La otra mitad de las menciones presente en el Discvrso es para referirse a las agudezas siempre como sustantivo al plural- que significan lo mismo que en el "Libro". Es decir, son figurae èlŏcūtǐonis, que en las reflexiones del sevillano son catalogadas como parte del ornatus del concepto poético. Para Jáuregui, estas agudezas son en sí mismas difíciles de hacer y de entender, hecho que recuerda a las poéticas dialógicas. Ahora bien, el sevillano -como el cuatralbo- defienden la dificultad poética, que la aleja del vulgo. Sin embargo, esta poética discursiva, que se posiciona contra la poesía moderna, prescribe un riguroso decoro entre rēs y verba y condena la cacocelía -la desproporción que nace del exceso de verba vacía. Partiendo de este principio y de la "metáfora de la punta"-decir mucho con poco-, me parece que el poeta ve en las agudezas una amenaza latente para la ruptura del decoro mencionado. Por tal motivo, considera que solo ingenios muy capaces pueden crear curiosa felicitas como Horacio, restringiendo al máximo su uso, al grado de callar lo más posible el término de agudeza.

Reitero que mi objetivo es observar cómo eran teorizados los términos de agudeza e ingenio en estas cinco poéticas y no compararlas con Agudeza y arte de ingenio de Gracián, como han hecho trabajos anteriores - pienso por ejemplo en la tesis doctoral de Fernández-Corugedo. No obstante, me parece evidente y notable que ya en las poéticas discursivas el término agudeza-siempre al estar como sustantivo plural- puede connotar aquello que Gracián conocerá años más adelante como agudezas verbales. Además, la racionalización del proceso poético por parte de Carrillo sugiere la posibilidad de crear un arte para una capacidad natural. Y esto no solo ocurre en aquellas poéticas más cercanas al fenómeno poético que las circunscribe. La misma poética de Cascales, aquella más apegada a la tradición clásica y renacentista, ya insinúa un proceso para "afilar" aptitudes poéticas.

Como se ve, las poéticas a caballo entre los siglos XVI y XVII no definen qué es agudeza sino que la consideran a partir de su etimología y de connotaciones que en la época pueden ser incluso lugares comunes -llamar agudo a alguien, por ejemplo. Sin embargo, estas son particularizadas con 
respecto a sus propias reflexiones sobre la poesía, llegando a adquirir además significados sociales, religiosos y éticos. Un resultado similar encontré para el término ingenio, aunque este adquiere también connotaciones a partir del complejo entramado de fuentes eclécticas en donde las poéticas de Aristóteles y Horacio y la obra de Huarte de San Juan cumplen un papel preponderante.

A propósito de las poéticas clásicas, es evidente la frecuencia con la que se parafrasean o aluden determinados pasajes al punto que estos se convierten en tópicos obligados y no solo para las poéticas de este corpǔs, sino para las teorizaciones y discusiones poéticas de los Siglos de Oro. Como prueba de esto, el capítulo 22 de la Poética de Aristóteles es el punto de partida para la discusión entre llanos y oscuros. Ahora bien, en las obras que me competen, además del pasaje mencionado, son de gran importancia los siguientes versos del Arte poética de Horacio, para el desarrollo del ingenio: los vv. 38-41-sobre la relación entre el ingenio del poeta y la materia poética que debe escoger-; los vv. 131-135 -la apropiación de la materia ya conocida-; los vv. 295-301 -Demócrito y la descripción del poeta furioso-; y los vv. 408-415 -la formación del poeta.

Por supuesto, existen numerosas citas a otras obras de Aristóteles -la Ética o la Metafísica, entre otras-y de Horacio -sus Sátiras, principalmente. Asimismo, como ya comenté en más de una ocasión, el tejido de fuentes y el eclecticismo de todos los autores es bastante intrincado y vasto. Por ahora, es mi intención subrayar los pasajes que interesan para connotar ingenio y cómo especialmente los humanistas de las poéticas dialógicas se apropian de estos. Así pues, de los versos de Horacio, quiero resaltar el 408 y el 409, porque de estos depende el binomio de la tópica horaciana: arteingenio. A este se agrega el fragmento 1455a 29-35 de la poética de Aristóteles, para discernir un punto fundamental en las reflexiones poéticas de la época: ¿el poeta nace o se hace? Dicho de otra forma, ¿el poeta necesita arte o ingenio para crear? La cuestión es resuelta en cada autor de diferente manera, dotando al término de connotaciones propias, algunas de las cuales se entrelazan con agudeza, como se habrá notado.

En primer lugar, siguiendo la tradición clásica, ingenio denota grosso modo una capacidad humana natural cuya labor es la creación. En términos retóricos, el campo del ingenio pertenece primordialmente al ámbito de la inventǐo. A partir de aquí, López Pinciano lo considera la causa eficiente de la poesía. No obstante, esto solo ocurre a partir de la "Epistola tercera", donde recupera la poética de Horacio y del tópico mencionado -"El poeta nace, y el orador se haze".

Al inicio de la Philosophia, Pinciano ve al ingenio como una capacidad propia de la parte racional del hombre. Además, depende del entendimiento y es común a todos los humanos, aunque algunos lo desarrollan de mejor manera que otros. Aquí no hay relación alguna con el arte, ni la creación poética, pero esto cambia con la paráfrasis del Arte poética (vv. 408-409), cuando el ingenio -natural inventivo- es considerado como causa eficiente, connotación que se mantiene en la poética 
dialógica. Con base en este cambio, quiero resaltar la importancia que las auctoritates tienen para determinar ciertas cualidades del término.

Asimismo, pese a que se confirma la connotación principal del ingenio en la Philosophia, la posición de este con respecto al arte varía según la fuente o fragmento que Pinciano cite. En consecuencia, al inicio acepta el principio horaciano y afirma que es necesario el arte y el ingenio por igual para la creación poética y que se le dará mayor importancia a uno u otro dependiendo de qué se valore: la causa material -arte - o la causa eficiente -ingenio. Por el contrario, al rechazar la ı̌mütātı̆o servil, retoma a Horacio (Arte poética, vv. 131-135) ahora para afirmar que el ingenio debe ser libre, con lo que da una mayor importancia a este que al arte.

A esto se aúna la teoría huartiana. Comenté que López Pinciano basa parte de su teoría en la disposición del cerebro y la teoría de los humores expuesta en el Examen. Gracias a esto, reinterpreta la teoría platónica de los furores y determina que el furor poético es un calor que destempla el ingenio del poeta. Así, el médico vallisoletano, fiel a su profesión, ofrece una explicación fisiológica de la inflamación poética, proceso que vuelve furioso al ingenio. En este proceso, el arte no interviene directamente, aunque sí se advierte que el "vuelo" -tópico privilegiado en las cinco poéticas- debe ser controlado con ayuda de aquel.

Finalmente, a partir del fragmento 1455a 29-35 de la poética aristotélica considera por un lado el ingenio furioso y por otro el ingenio versátil, que puede recibir fácilmente las ideas y amoldarse a diferentes situaciones, como su nombre lo indica. Estos dos tipos conforman el ingenio natural y es posible que el poeta solo posea uno de ellos, aunque se recomienda que estén presentes ambos de forma equilibrada para que el poeta sea excelente. Sobre estas afirmaciones, quiero apuntar la cualidad que tiene el ingenio versátil para recibir ideas. Aunque las connotaciones han cambiado, Pinciano afirmó que el ingenio era parte del entendimiento. No se ahonda al respecto, pero me parece que el ingenio pincianesco no solo posee una capacidad inventiva, sino también receptiva. De hecho, a causa de esto considero posible que en la Philosophia esté presente tanto la inventĭo como su proceso anterior, la intellectǐo.

En la Philosophia no se define explícitamente qué es ingenio, pero sí se ofrece y define brevemente una tipología -furioso y versátil. La importancia de estos tipos es tal que el aspirante a poeta debe por lo menos poseer un poco de alguno de estos para poder crear versos. Asimismo, es la capacidad encargada de asegurar la ütĭlittās poética para la República. Entonces, el arte es incapaz de crear por sí mismo, además de que la obra preeminente nace únicamente de un ingenio natural equilibrado. López Pinciano no niega en ningún momento la necesidad del arte; sin embargo, observé una inclinación por el ingenio natural inventivo, aspecto que lo acerca sutilmente a Carvallo y a 
Jáuregui. Además, la relación entre ingenio y entendimiento posee un desarrollo importante en Carrillo y Sotomayor y también en Jáuregui.

El ingenio en el Cisne tiene un papel aún más importante. Al igual que Pinciano, Carvallo relaciona estrechamente ingenio y entendimiento. Sin embargo, el asturiano los distingue claramente con una capacidad que posee el primero: la imaginativa, cuyo limitante es el entendimiento. Para desarrollar esta, el jesuita sigue de cerca la doctrina de Huarte de San Juan pues se indica que necesita de calor y sequedad para manifestarse, pero no somatiza completamente el proceso poético como el vallisoletano. El poeta efectivamente requiere de una disposición cerebral particular así como de una capacidad particular: la vena. Esta última es una gracia divina que permite al ingenio inflamarse con el furor y volverse así agudo, con lo que se enaltece su capacidad receptora. Como referí más arriba, este tipo de ingenio permite "alzar el vuelo" como el cisne y acercarse a la divinidad. Carvallo relaciona la figura del profeta a la del poeta.

Observo cómo en el Cisne se le reconoce una gran capacidad al ingenio, lo que le permite intervenir principalmente en la invenť̌o, y en ocasiones en la dispŏsĭtĭo e incluso en la èlŏcūtřo. El ingenio agudo permite al poeta "penetrar" en asuntos divinos, o bien distinguir correctamente entre lo bueno y lo malo, con lo que obtiene su materia poética. Además, siguiendo a Horacio (Arte poética, vv. 38-41), determina qué género conviene al poeta dedicarse. Por otra parte, escoge qué se debe decir y qué no en los exordia de la comedia. O bien, es una muestra de ingenio ocultar conceptos con figuras, con lo cual no se busca la obscūrittās, todo lo contrario, puesto que se trata de una capacidad aclaradora.

El ingenio carvallesco se caracteriza por ser claro, porque puede comprender cabalmente los conceptos -rēs-y exponer con persp̌čŭtās la verba que cubre a estos. En otras palabras, el ingenio tiene la función de velar con tropos la materia poética para motivar al receptor a descifrarlos, lo cual le ofrece una enseñanza útil -gracias a la correcta selección de la rēs-y le produce a su vez placer. La poesía, con ayuda del ingenio poético, consigue su causa final: dōcēre ět dēlectāre. Sin embargo, esto no es posible únicamente con dicha capacidad humana.

La poética dialógica de Alfonso de Carvallo es sin duda una poética retoricada. La forma que le da a su reflexión sigue de cerca los principios del ars běnĕ dīcendi, pues sus fuentes medievales Badius, la principal- poseen esta fuerte carga, lo que explica la falta de citas de Horacio y Aristóteles para referirse al término que me ocupa. De esta forma, se exalta el ingenio y su cualidad divina, pero de ir por sí mismo existe el peligro de que se equivoque. La potencialidad creadora de la capacidad nata es tal que puede crear obras poéticas buenas o perniciosas.

Carvallo es un profesor jesuita y para exaltar el oficio del poeta prescribe un arte y, más aún, una moral que se infiere en el emblema del cisne. Esta ave blanca que levanta el vuelo suavemente 
es la insignia propia del poeta, representa su ingenio agudo, sutil, delicado y claro. No obstante, también representa el quehacer poético porque el cisne está relacionado con Apolo y finalmente con Cristo, ya que el asturiano cristianiza el mundo pagano de sus auctoritates. Como consecuencia de la relación cisne-Cristo, el poeta se cristianiza y nuevamente se le equipara al profeta, cuyo furor poético no necesita de arte alguno. Lo contrario ocurre con el poeta que necesita un arte para poder encauzar correctamente la potencialidad de su ingenio y evitar el error.

Quiero enfatizar que el arte de Carvallo -su poética y propuesta estética-implica una fuerte doctrina cristiana, en donde la tradición emblemática es fundamental. Las constantes relaciones poeta-profeta y la reveladora comparación entre el cisne y Cristo no son solamente argumentos que enaltecen y justifican el carácter divino de la poesía, así como su ūtǔlĭtās para la República. Me parece que el jesuita crea un arte para encauzar la admirable capacidad del ingenio poético a una creación poética provechosa y cristiana. Entonces, este último puede explotar sus cualidades, siempre y cuando sea guiado por el arte. El binomio arte-ingenio en el Cisne mantiene un peculiar equilibrio, porque se enaltecer al segundo, pero en todo momento se enfatiza la necesidad del arte, cuya importancia no es poca si se consideran sus implicaciones doctrinales y morales.

El equilibrio de esta balanza se pierde en las Tablas. Cascales no le dedica mucho espacio al ingenio en su poética porque desde el principio es claro: el arte debe primar en el quehacer poético. Esta es la justificación del murciano para la creación de su poética, ya que considera que sus contemporáneos han hecho un uso excesivo de su ingenio. A este no se le niega su denotación capacidad creadora- y afirma que es fecundísimo, pero es incorrecto depender de este como los escritores de la comedia nueva, a la que critica duramente. Cascales establece entonces un arte en donde la ı̌mütātǐo de las auctoritates es fundamental y el papel del ingenio se reduce lo más posible, mientras que el furor solo se menciona como tópico a partir de los versos de Horacio (Arte poética, vv. 295-301) para ridiculizar al poeta furioso.

Por otra parte, como Carvallo, Cascales establece una de las funciones del ingenio a partir de su glosa a los vv. 38-41de la poética horaciana y afirma que el tipo de ingenio determina a cuál género debe dedicarse el poeta. El humanista no profundiza mucho al respecto, como tampoco lo hace en la otra tarea que da al ingenio en tanto capacidad inventiva: la creación de episodios en la comedia -un género del hümülis stylus - a partir de la retractio, una prueba de ingenios. Como ya comenté con respecto a la agudeza, esta última connotación es bastante particular y evidencia que Cascales no prescribe la ı̆mítăť̆o servil. Para esto el ingenio es imprescindible, aunque nuevamente no ahonda más al respecto.

El silencio que Cascales guarda con respecto al ingenio me parece elocuente. Observé en su momento que en las Tablas se señala a los poetas que solo se dejan llevar por sus ingenios y que de 


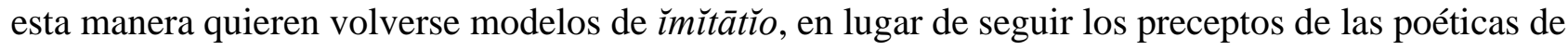
Aristóteles y Horacio y los modelos clásicos. El humanista acusa a estas obras de falsedad y demerita cualquier valor artístico que puedan poseer. Opino que en estas consideraciones radica principalmente la omisión del término.

Cascales reconoce la gran fuerza creadora del ingenio, sabe que las obras hechas únicamente a partir de este, y que no siguen totalmente el arte de los grecolatinos, pueden ser puntos de partida para crear nuevas artes poéticas. En otras palabras, Cascales en la comedia nueva -que ataca abiertamente en las Tablas - y posiblemente en la poesía de sus contemporáneos ya percibía un cambio de estética, de la cual era responsable principalmente el ingenio español. En consecuencia, el humanista manifiesta su inconformidad con una propuesta poética que abraza el arte de las auctoritates y calla el ingenio. De cierta forma, Cascales y Jáuregui se comportan igual con respecto a lo que consideran una amenaza a su propuesta poética: silenciarlo.

Me parece evidente que en las poéticas dialógicas las connotaciones del ingenio parten de sus auctoritates -Aristóteles, Horacio y Huarte principalmente. No obstante, el resultado varía notablemente con respecto a la teoría de cada humanista. Así, el binomio arte-ingenio se inclina según los intereses de cada poética. En consecuencia, para López Pinciano no hay problema en inclinar su poética esencialmente aristotélica hacia su causa eficiente -un ingenio poético que es furioso y versátil. Carvallo exalta y diviniza el ingenio agudo, sutil, delicado y claro, pero lo equipara con la atención dada al arte -doctrinal y moral. Finalmente, Cascales, consciente de la poesía de su tiempo, prescribe una poética en donde el arte es más importante que el ingenio.

Las poéticas discursivas parten igualmente de sus auctoritates; sin embargo, al defender y atacar un tipo de poesía, se vuelve más compleja la relación arte-ingenio, así como las connotaciones que este último adquiere. De cualquier manera, la denotación de "capacidad creadora" se mantiene, así como algunas peculiaridades. En consecuencia, la poética de Carrillo tiene puntos de unión con la de Carvallo y Pinciano, a la vez que se distancia de estas y de la tradición de la que parten. Esto debido a que su propuesta, la poética de la erudición, vuelve insuficiente el binomio arte-ingenio, que complejiza para volverlo erudición-entendimiento.

El "Libro" privilegia sin duda alguna el entendimiento sobre el ingenio. Estos tienen una relación, puesto que son capacidades naturales del individuo, aunque tal punto no se desarrolla en una posible sinonimia, porque cada uno de ellos tiene su propia función. El ingenio para el cuatralbo es fertilísimo y se le implica en la èlǒcūtřo. Aspecto notable pues aquí se juega la estética de la poesía erudita. Sin embargo, no se desarrollan particularmente dichas connotaciones, que parten de su propia denotación. Como ocurre con Cascales, no se le niega la capacidad creadora al ingenio y de ahí su 
papel fundamental en las poéticas, pero es evidente que el entendimiento es donde Carrillo concentra su atención y reflexiones.

Al revisar la connotación de agudeza como adjetivo de entendimiento, señalé que este se "afilaba" gracias a la erudición. Asimismo, aludí que el proceso es una consecuencia de la racionalización del proceso poético que realiza Carrillo y Sotomayor en su poética dialógica. Por ello, incluso el mártir -relacionado al poeta- pueda crear con ayuda del furor divino o bien de la afición, que implica una preparación y dedicación por parte del individuo. Considero entonces que el cuatralbo encuentra en el entendimiento la capacidad humana que puede ser educada -"afilada"- y así esta es la que halla la materia poética en los misterios de las musas.

Por otra parte, señalé en el análisis del "Libro" que existía una dualidad compleja entre la divinidad y la racionalidad propia de la poesía erudita. Esto significa que lo anterior no niega la divinidad poética, la cual recae precisamente en el ingenio -como ocurre en parte en Carvallo. Me parece que Carrillo no profundiza mucho en este último precisamente porque no puede racionalizarlo. Es decir, lo coloca como una capacidad inventiva cuya divinidad aleja al poeta del vulgo, de aquí que intervenga en la èlŏcūtǐo. El ingenio es pues la justificación natural de la superioridad del poeta.

En suma, la poesía erudita, escrita por doctos para sus iguales, se caracteriza principalmente por el binomio entendimiento-erudición, en donde el trabajo del poeta es el que lo eleva a los misterios divinos. Sin embargo, no se le niega al ingenio su denotación de raigambre clásica y se le connota en consecuencia como capacidad divina propia del poeta, la cual se acompaña del mencionado binomio para guiar sus creaciones. Además, hay una connotación al final del "Libro" que no quiero dejar de mencionar. Carrillo señala que los ingenios buenos son los encargados de resguardar el saber. No hay un desarrollo particular sobre esta connotación - como todo lo que incumbe a esta capacidad-, pero me parece que es una forma de enfatizar la divinidad de la capacidad, ya que está preservando los misterios de las musas.

La tópica horaciana arte-ingenio se recupera en la segunda poética discursiva y el ingenio, así como en la poética de Carvallo, tiene un papel importante, aunque por diferentes razones. El Discvrso es la poética del corpŭs que más connotaciones le da a este término y la razón es que explota tanto su fuerza creadora como su cualidad receptora. Por esto, desde el principio Jáuregui establece que el ingenio por sí mismo puede develar los misterios divinos, con lo que crea conceptos de ingenio. De esta forma, la tradición de Huarte -recuperada por Pinciano y Carvallo- es resignificada: el furor es llamado aliento e inflama al ingenio para que busque grandez hazañas.

Ahora bien, las connotaciones del ingenio están determinadas por el objetivo de la poética: advertir sobre los peligros de la poesía moderna. Noté con base en esto que la inflamación del ingenio por el aliento es necesaria para la creación poética; sin embargo, si el ingenio no logra encauzar la 
inflamación o solo depende de esta, se despeña creando una obra de verba furiosa -exceso de palabras vacías- carente de conceptos sublimes. En otras palabras, el poeta cae en la cacocelía.

Para evitar estos vicios, el poeta sevillano propone el segundo elemento de la tópica horaciana: el arte. No obstante, como ocurre en el "Libro", este es más complejo porque la fuerza del ingenio es tal que no es suficiente. Se necesita entonces arte, pero también stŭdŭum y prudencia para procurar el decoro entre rēs y verba. Sin embargo, quiero enfatizar que el origen de la excelencia de la obra poética es el ingenio, ya que si este es pobre e inhábil no conseguiría más que una ĭmĭtătǐo servil. Además, arte y stŭdĭum, aunados al ingenio, garantizan un estilo elegante, el cual incluso ha sido enmendado por el mismo ingenio del poeta -función que solo tiene en esta poética. En consecuencia, el poeta le da dificultad -no obscūrĭtās-y dignidad a la obra poética, porque en el Discvrso también se propugna por una poesía no apta para el vulgo, como el "Libro", pero matiza el elitismo intelectual.

El Discvrso es una poética dedicada al Conde Olivares y por esto considera a su público cortesano. A partir de esto crea una compleja tipología de ingenios con base en la capacidad receptiva del público. El nivel más bajo corresponde al ingenio plebeyo, aquel propio del vulgo y que no es un digno intérprete de la poesía. De hecho, es el ingenio que puede aplaudir la viciosa poesía moderna. Por el contrario, los alentados ingenios cortesanos - propios de la corte y evidentemente superiorestienen buen gusto, son observadores e inclinados al arte. Como consecuencia de estas cualidades perciben la grandeza de ingenio en la poesía. Precisé que el ingenio del receptor como el del poeta deben estar alentados e inclinados al arte para que el primero pueda comprender al segundo.

De lo anterior, el aliento es la característica más importante que comparten los dos ingenios creador y receptor. Así, interpreto que el ingenio alentado -no cortesano- se refiere a los humanistas que con el stŭd̆̌um logran tanto disfrutar la poesía como entender los misterios que encierra. Y los comprenden aún más los grandes ingenios que se basan únicamente en el arte y la práctica constante. Apreciar, juzgar correctamente y comprender las obras de un ingenio divino, empero, solo lo puede hacer el entendimiento divino. En este último observo además cómo entendimiento e ingenio se vuelven sinónimos, lo que no ocurre en el "Libro". La capacidad receptora del ingenio que la poética de Pinciano apenas esboza, es explotada en su totalidad, al punto de que ambas capacidades son intercambiables, en tanto cumplen la misma función: comprender una obra poética.

Quiero precisar que a través del estilo es cómo esta escala de ingenios receptores observa el ingenio poético. He señalado varias veces que en la êlŏcūtǐo se juega la poética tanto de Carrillo como de Jáuregui. Por esto, el estilo poético -contrario al estilo llano- es comprendido en sus diferentes grados. El estilo poético puede ser mayor o superior dependiendo del tipo de ingenio que tenga el individuo que escucha o lee el poema. Asimismo, Jáuregui establece otra relación entre el ingenio poético y el receptor, y el estilo que se crea o interpreta. 
Jáuregui usa un tópico de la época, el ingenio español, pero lo reformula y le confiere una connotación particular. En principio, con este defiende un aspecto fundamental en la poética: el carácter propio de la lengua y poesía nacional en comparación de otras -la italiana principalmente. Además, debido a su superioridad, dicho ingenio español le exige al ingenio poético un estilo mayor, porque no se conforma con una poesía sencilla y llana. El poeta sevillano comprende las necesidades del público y que por satisfacerlo los poetas hayan pretendido depender del ingenio sin recurrir al trabajo que requiere el arte y stŭd̆̌um. Por esto se les condena a los poetas modernos y no por intentar satisfacer a los ingenios españoles deseosos de las galas de ingenio.

A diferencia de Carrillo y Sotomayor - quien considera al poeta juez de sí mismo-, el sevillano sí considera el deleite del público, aunque este no debe determinar la calidad de la obra poética. Precisamente por esto posee diferentes niveles de interpretación según el ingenio del receptor. Entre estos, solo el divino puede comprender cabalmente los conceptos de ingenio cubiertos con las galas de ingenio. En otras palabras, solo el poeta puede comprender y disfrutar completamente a otro poeta que posea su misma fuerza del ingenio.

El ingenio en el Discvrso es también claro. Como en la poética de Carvallo, es una capacidad que encuentra misterios y los declara con la verba indicada. Por estas dos funciones -propias de la inventı̆o y la élŏcūtı̌o- la fuerza creadora del ingenio garantiza el decoro entre rēs y verba, y evita la cacocelía. Por supuesto, necesita de otras prácticas y capacidades para conseguirlo, por lo que el binomio arte-ingenio se equilibra. No obstante, considero que el papel de un ingenio bien dispuesto es determinante. Como consecuencia, esta capacidad permea la poética discursiva y se adjetiva con diferentes cualidades que connotan sus aptitudes para la creación y recepción de la poesía.

Opino que las poéticas discursivas particularizan el binomio arte-ingenio: en el "Libro" este se modifica y en el Discvrso arte se complejiza y la capacidad del ingenio se explota. Por tanto, sus connotaciones difieren en parte de las dialógicas, pues para Carrillo es la justificación divina de la poesía y para Jáuregui es la capacidad encargada de la creación y recepción poética. Algunas de estas connotaciones ya pueden encontrarse en las poéticas dialógicas, pero considero que es en las discursivas en donde se desarrollan y complejizan, pues ambas parten de una práctica poética que sus mismos autores practican.

Aunado a lo anterior, me parece que las convergencias y divergencias de las reflexiones poéticas de cada autor son evidentes en aquello que determina la causa final de la poesía, lo cual ayuda a explicar mejor los términos que me interesan. Así, en las cinco poéticas se sigue tanto la tradición del sistema aristotélico como el binomio horaciano dŏcēre ĕt dēlectāre, en el que se resuelve la finalidad de la poesía. Con base en esto, en el corpŭs observé que solo en el "Libro" imperaba el dēlectāre, específicamente del poeta, puesto que este es el único capaz de entender y juzgar la poesía 
erudita. En cambio, las poéticas dialógicas y el Discvrso consideran como causa final dŏcēre y dēlectāre. Sin embargo, el equilibrio entre los dos varía.

Pinciano alterna entre uno y otro, según la causa con la cual se juzgue la obra poética: si se evalúa la causa eficiente (ingenio) entonces el dēlectāre es el fin, pero si se valora la causa material $(r \bar{e} s)$ es el dŏcēre. No obstante, hay una ligera tendencia a priorizar el deleite poético. Por su parte, Carvallo y Cascales consideran ambos extremos del binomio importantes, aunque su opinión es más doctrinal, puesto que el délectāre atrae el interés del receptor, para que reciba con agrado el dŏcēre. Finalmente, Jáuregui considera también el binomio completo, aunque es evidente que tiene preferencia por el dēlectāre. En suma, mientras en las poéticas dialógicas existe un aparente equilibrio entre dŏcêre ĕt dēlectāre, en las discursivas hay una tendencia hacia el segundo, lo cual se explica nuevamente por la relación que tienen con la práctica poética y por su objetivo -didáctico o apológico.

A propósito de la causa final quiero observar dos aspectos que creo reveladores. El primero es cómo, a partir de esta, las poéticas de Carvallo y Cascales -que han sido consideradas como opuestas- se relacionan, a la vez que el Cisne y el "Libro" - con tanto en común- se distancian. Asimismo, el Discvrso desarrolla la tendencia al délectāre ya presente en la Philosophia, misma que el "Libro" explota hasta sus últimas consecuencias. Las relaciones entre una poética y otra se vuelven pues más complejas, lo que demuestra además la forma en la que la tradición clásica se compartió, diversificó y particularizó.

El segundo aspecto lo asocio con agudeza e ingenio. Ambos están implicados en el binomio horaciano y explican la importancia que adquiere una u otro en cada poética. En consecuencia, el ingenio está relacionado con el dèlectāre, como noto en la Philosophia, en el Cisne y en el Discvrso. Por esto, Carvallo -que procura el dōcēre a través del dēlectāre-califica al ingenio como claro y lo refrena con el arte. Jáuregui también hace hincapié en el arte, pero permite que la gran fuerza del ingenio actúe, priorizando el dèlectāre. Contrario a esto, Cascales calla lo más posible el ingenio para evitar que su fuerza incline la balanza dōcēre ět dēlectāre hacia el segundo.

El caso de Carrillo parece contradecir lo anterior, pues privilegia el dēlectāre y trata poco del ingenio. La razón obedece a que el primero está determinado en el "Libro" por la agudeza, la cual se relaciona principalmente con el dŏcēre en las poéticas dialógicas del corpŭs. Lo “puntiagudo" permite penetrar en los grandes conceptos que la poesía enseña al público, metáfora que también se aprovecha en el "Libro", aunque enriquecida por la erudición poética y negada al dōcēre de los indoctos. De hecho, está implícito que el dēlectāre en la poética es de carácter erudito -en concordancia con el resto de la propuesta poética- cuando Carrillo "afila" el entendimiento que penetra en los misterios de las Musas. Por esto mismo, el cuatralbo no recurre tanto al arte, sino a la erudición -base del "Libro". 
Sin duda, la poética de Carrillo y Sotomayor complejiza reflexiones que apenas se aluden en las poéticas dialógicas. Asimismo, el Discvrso es la amplüfícātřo de ciertos aspectos presentes en estas, como se ve en las connotaciones del ingenio. Entonces, las poéticas discursivas son el ápice de las observaciones que Pinciano, Carvallo y Cascales realizan, y, sintomáticamente, una prioriza la agudeza y la otra el ingenio.

No me parece, empero, que las poéticas discursivas sean más valiosas para la reflexión en torno a agudeza e ingenio -capacidad que incluso deja de reducirse solo a la inventio en las cinco poéticas. He anotado que el corpŭs es rico en cuestiones estéticas, sociales, religiosas, e incluso nacionales y médicas. Evidentemente, algunas profundizan más en un aspecto que en otro. Sin embargo, considerarlas individualmente y en conjunto demuestran la complejidad del tejido cultural de la época. Las convergencias y divergencias entre ellas confirman por un lado su pertenencia a una parte de la tradición y por otro su propuesta poética. Esto lo he observado únicamente al analizar dos términos imprescindibles para la poesía de la época, por lo que considero que es necesario ahondar más en este corpŭs. Leerlo no como una repetición de otras teorías, sino como una voz propia que es resultado de un complejo diálogo con la tradición clásica y moderna. Además, me parece muy probable que al comparar esta voz teórica con otras voces poéticas se pueden resignificar las interpretaciones que hasta el momento la crítica les ha dado. Para el filólogo hay todavía una gran labor por delante. 


\section{BIBLIOGRAFÍA}

\section{Corpūs}

Alonso de Carvallo, Luis, Cisne de Apolo, de las excelencias, y dignidad y todo lo que al Arte Poetica y versificatoria pertenece. Los metodos y estylos que en sus obras deue seguir el Poeta. El decoro y adorno de figuras que deuen tener, y todo lo mas a la Poesia tocante, significado por el Cisne, ynsignia preclara de los Poetas. Por Luys Alfonso de Caruallo clerigo. Dedicado a don Henrique Pimentel de Quiñones. Con licencia del Consejo Real. A costa de Pedro Ossete, y Antonio Cuello, Medina del Campo, por Iuan Godinez de Millis, 1602. Disponible en línea: https:||bibliotecavirtual.asturias.es|i18n|consulta|registro.cmd?id=669.

CARrillo y Sotomayor, Luis, Obras de Don Luys Carrillo y Sotomayor, cavallero de la Orden de Santiago, Comendador de la Fuente del Maestre, Quatraluo de las Galeras de España, natural de la Ciudad de Cordoua. A Don Manuel Alonso Perez de Guzman el Bueno, Conde de Niebla, Gentilhombre de la Camara de su Magestad, y Capitan Geneal de la Costa de Andaluzia. Con privilegio, Madrid, por Iuan de la Cuesta, 1611. Disponible en línea: http:||bdhrd.bne.es|viewer.vm?id=0000078074\&page $=1$.

, Obras [de] Don Luys Carrillo y Sotomayor, Comendador de la

Fuente del Maestre, Quatraluo de las Galeras de España. Natural de Cordoua. A Don Manuel Alonso Perez de Guzman el bueno, Conde de Niebla, Capitan general de la Costa de Andaluzia. Con priuilegio, Madrid, por Luys Sanchez, 1613. Disponible en línea: http:||bdhrd.bne.es|viewer.vm?id=0000011000\&page $=1$.

CAscales, Francisco, Tablas poeticas, del licenciado Fancisco Cascales. Dirigidas al Excelentissimo Señor Don Francisco de Castro, Conde de Castro, Duque de Taurisano, Virrey, y Capitan general del Reyno de Sicilia. Con privilegio, Murcia, por Luis Beros, 1617. Disponible en línea: http:||bdh-rd.bne.es|viewer.vm?id=0000079374\&page=1.

JÁUREGUI, Juan de, Discuros poetico de don Iuan de Iauregui. Al Excelentissimo Señor Don Gaspar de Guzman, Conde de Olivares, Sumilier de Corps, Cavallerizo mayor, del Consejo de Estado y Guerra de su Magestad, gran Canciller de las Indias, Alcaide perpetuo de los Alcaçares de Sevilla, Comendador mayor de Alcantara,\&c. Con privilegio, Madrid, por Iuan Gonçalez, 1624.

Disponible

en

línea:

https:||books.google.com.mx|books|ucm?vid=UCM5326185337\&printsec=frontcover\&redir_esc=y\# $\mathrm{v}=$ onepage $\& \mathrm{q} \& \mathrm{f}=$ false.

LóPez Pinciano, Alonso, Philosophia Antigva poetica del Doctor Alonso Lopez Pinciano, Medico Cesareo. Dirigida al Conde Ihoanes Keue[n]hiler de Aichelberg, Conde de Frankemburg, Baron absoluto de Landtscron y de VVernsperg, Señor de Osteruiz y Carlsperg, Cauallerizo 
Mayor perpetuo y hereditario del Archiducado de Carinthia, Cauallero de la orden del Tuson del Rey nuestro señor, y del Consejo y de la Camara del Emperador, y su Embaxador en las Españas, Madrid, por Thomas Iunti, 1596. Disponible en línea: http:||bdhrd.bne.es|viewer.vm?id=0000095964\&page $=1$.

\section{Obras de consulta}

ÁlvareZ, Francisco J., Ignacio García Aguilar e Inmaculada Osuna, "Seventeenth-Century Academies in the City of Granada: A Compartist Approach", en Arjan Van Dixhoorn y Susie Speakman Sutch (eds.), The Reach of the Republic of Letters. Literary and Learned Societies in Late Medieval and Early Modern Europe, II, Leiden-Boston, Brill, 2008, pp. 309-336.

Alatorre, Antonio, Fiori di sonetti / Flores de sonetos, México, El Colegio de México y Aldus, 2009.

ARISTÓTELES, Retórica, Quintín Racionero (trad. y ed.), Madrid, Gredos, 2014.

ARriaga NAVARro, Marx, ¿Qué era el verso en los siglos XVI y XVII? En busca de una teoría del verso en las poéticas del Siglo de Oro, tesis de maestría, CDMX, UAM, 2006.

BARBERIS, Walter, "Baldassar Castiglione. Gli ultimi bagliori dell'Umanesimo”, en Baldassar Castiglione, Il libro del Cortegiano, W. Barberis (ed.), Torino, Einaudi, pp. V-LXVII.

BATAILlon, Marcel, Erasmo y España. Estudios sobre la historia espiritual del siglo XVI, Antonio Alatorre (ed.), México, Fondo de Cultura Económica, 2013.

BERMúDEZ, Alex, "Lectura y crítica del Fedro platónico por un crítico aristotélico del siglo XVI: el Pinciano contra los 'divinos furores' (Phaed. 243e9-245c5)”. Disponible en línea: https://www.academia.edu/15397294/Lectura_y_crítica_de_El_Pinciano_a_los_furores_divinos_de_ Platón_Phaed._243e9-245c5_?auto=download.

Blanco, Mercedes, “Introducción” a Juan de Jáuregui, Discurso poético, M. Blanco (ed.), s. p., 2016.

Disponible en línea: https://obvil.sorbonne-universite.fr/corpus/gongora/1624_discurso-poetico\#body-1-1. , “La oralidad en las justas poéticas”, Edad de Oro, VII (1988), pp. 33-57. , Les Rhétoriques de la Pointe. Baltasar Gracián et le Conceptisme en Europe, Genève, Editions Slatkine, 1992. , "Poéticas, retóricas y estudio crítico de la literatura", Bulletin Hispanique, t. 106, n. 1 (2004), pp. 213-233. Disponible en línea: https://www.persee.fr/doc/hispa_00074640_2004_num_106_1_5189.

BRANCAFORTE, Benito, “Introducción” para Francisco Cascales, Tablas poéticas, Benito Brancaforte (ed.), Madrid, Espasa-Calpe, 1975, pp. IX-XLI. 
BunKe, Peter, “Il cortigiano”, en Eugenio Garin (ed.), L'uomo del Rinascimento, Bari, Laterza, 1988, pp. 133-165.

CALERO, Francisco, “Ingenioso e ingenio en el Quijote”, eHumanista, 30 (2015), 139-147. Disponible en línea: https://dialnet.unirioja.es/descarga/articulo/5473872.pdf.

, "La autoría de la Philosophía antigua poética", Estudio de autoría de «Los Trabajos de Persiles y Segismunda», «Philosophía antigua poética» y «Novelas ejemplares», Dykinson, Madrid, 2017, pp. 305-386.

CARdenal Iracheta, Manuel, "Nota bibliográfica" para Luis Carrillo y Sotomayor, Libro de la erudición poética, Manuel Cardenal Iracheta (ed.), Madrid, C.S.I.C., 1946, pp. V-XVI.

CARreira, Antonio, "El conceptismo de Góngora y el de Quevedo", Il Confronto Letterario, 52 (2009), pp. 353-377.

CARrillo y Sotomayor, Luis, Libro de la erudición poética, Angelina Costa (ed.), Sevilla, Ediciones Alfar, 1987.

Obras, Rosa Navarro (ed.), Madrid, Castalia, 1990.

Carvallo, Luis Alfonso, Cisne de Apolo, Alberto Porqueras Mayo (ed.), Kassel, Edition Reichenberger, 1997.

CASCALES, Francisco, Tablas poéticas, Benito Brancaforte (ed.), Madrid, Espasa-Calpe, 1975.

Castiglione, Baldassare, Il libro del Cortiggiano, Walter Barberis (ed.), Torino, Einaudi, 2017.

CERCHI, Paolo, "Enciclopedias y organización del saber de la antigüedad al Renacimiento", en Evangelina Rodríguez Cuadros, De las academias a la Enciclopedia: el discurso del saber en la modernidad, Valencia, Edicions Alfons el Magnànim, Institució Valenciana d'Estudis i Investigació, pp. 69-94.

CERDÁ Y RiCO, F., "Prólogo al lector” para Francisco Cascales, Tablas poeticas del Lic. Francisco Cascales. Añadese en esta II. impresión: Epistola Q. Horatii Flacci de Arte Poetica in methodum redacta, versibus horatinais stantibus, ex divrsis tamen locis ad diversa loca translatis. Item: Novae in Grammaticam observationes. Item: Discurso de la ciudad de Cartagena, F. Cerdá y Rico (ed.), Madrid, por Antonio de Sancha, 1779, pp. III-XIV. Disponible en línea: http://bdh-rd.bne.es/viewer.vm?id=0000091370\&page=1.

Cicerón, Marco Tulio, Sobre el orador, José Javier Iso (trad.), Madrid, Gredos, 2002.

Corominas, Joan, Diccionario crítico etimológico de la lengua castellana, II, Madrid, Gredos, 1974.

Cossío, José María de, Fábulas mitológicas en España, Madrid, Espasa-Calpe, 1952.

Costa, Angelina, "Introducción" a Luis Carrillo y Sotomayor, Libro de la erudición poética, Angelina Costa (ed.), Sevilla, Alfar, 1987, pp. 9-41. 
“Introducción” a Luis Carrillo y Sotomayor, Poesías completas, Angelina Costa (ed.), Madrid, Cátedra, 1984, pp. 7-48.

Covarrubias Horozco, Sebastián de, Tesoro de la lengva castellana, o española. Copvesto por el licenciado Don Sebastian de Cobarruuias Orozco, Capellan de su Magestad; Mastrescuela y Canonigo de la santa Iglesia de Cuenca, y Consultor del santo Oficio de la Inquisicion, Madrid, por Luis Sanchez, 1611. Disponible en línea: http://fondosdigitales.us.es/fondos/libros/765/descargar/tesoro-de-la-lengua-castellana-o-espanola/.

CURTIUS, Ernst Robert, Literatura europea y Edad Media latina, I, Margit Frenk y Antonio Alatorre (trads.), México, FCE, 2012.

DÁMAso, Alonso, "Sobre Don Luis Carrillo", Obras completas, III, Estudios y ensayos sobre literatura. Segunda parte. Finales de siglo XVI, y siglo XVII, Madrid, Gredos, 1974, pp. 701735.

DAZA SomoAno, Juan Manuel y Jaime Galbarro García, "Hacia una catalogación de las más importantes retóricas españolas del siglo XVI. Tradiciones, modelos y tendencias”, en Begoña López Bueno (ed.), El canon poético en el siglo XVI. VIII Encuentro Internacional sobre Poesía del Siglo de Oro, Sevilla, Grupo PASO, Universidad de Sevilla y Secretariado de Publicaciones, 2008, pp. 75-108.

DíAZ RENGIFO, Juan, Arte poetica española con una fertilissima sylua de Consonantes Comunes, Propios, Esdruxulos, y Reflexos, y vn diuino Eestimulo del Amor de Dios. Por Ivan Diaz Rengifo natural de Auila. Dedicada a D. Gaspar de Zuñiga, y Azeuedo Conde de Monterey, y señor de la casa de Viezma y Vlloa [et]c., Salamanca, casa de Miguel Serrano de Vargas, 1592. Disponible en línea: http://bdh-rd.bne.es/viewer.vm?id=0000091336\&page=1.

Diccionario de la lengua castellana, en que se explica el verdadero sentido de las voces, su naturaleza y calidad, con las phrases o modos de hablar, los proverbios o refranes, y otras convenientes al uso de la lengua. Disponible en línea: http://web.frl.es/DA.html.

DiEZ ECHARRI, Emiliano, Teorías métricas del Siglo de Oro. Apuntes para la historia del verso español, Madrid, C. S. I. C., 1970.

EGIDO, Aurora, "La dignidad humanística de la escritura", Bulletin Hispanique, t. 114, no. 1 (2012), p. 10.

, "La fuerza del ingenio y las lecciones cervantinas", BRAE, t. XCVI, cuaderno CCCXIV (2016), pp. 771-794.

, "La hidra bocal. Sobre la palabra poética en el Barroco”, Edad de Oro, VI (1987),

pp. 79-113. 
, “Literatura efímera: oralidad y escritura en los certámenes y academias de los Siglos de Oro", Edad de oro, VII (1988), pp. 69-88.

, “'Sin poéticas hay poetas'. Sobre la teoría de la égloga en el Siglo de Oro”, Criticón,

30 (1985), pp. 43-77. Disponible en línea:

https://cvc.cervantes.es/literatura/criticon/PDF/030/030_045.pdf.

, “Una introducción a la poesía y a las Academias Literarias del siglo XVII”, Estudios

humanísticos. Filología, 6 (1984), pp. 9-26. Disponible en línea: https://dialnet.unirioja.es/servlet/articulo?codigo $=104658$.

FERnÁndeZ-Corugedo, Víctor, El ingenio desde los Presocráticos hasta Gracián, tesis doctoral, Stockholms, Stockholms Universitet, 1998.

FERRER DE AlBA, Inmaculada "Introducción” a J. de Jáuregui, Obras, I, Rimas, I. Ferrer de Alba (ed.), Madrid, Espasa-Calpe, 1973, pp. V-XLII.

FRENK, Margit, Entre la voz y el silencio. La lectura en tiempos de Cervantes, México, FCE, 2005. , "Más sobre la lectura en el Siglo de Oro: de oralidades y ambigüedades”, en Florencio Sevilla y Carlos Alvar (eds.), Actas del XIII Congreso de la Asociación Internacional de Hispanistas. Madrid 1988, I, Medieval. Siglos de Oro, Madrid, Asociación Internacional de Hispanistas, Castalia, Fundación Duques de Soria, 2000, pp. 516-521.

GAMBIN, Felice, "Menosprecio de la literatura y alabanza de filosofía: Huarte de San Juan y la imaginación vigilada", en Christoph Strosetzki (ed.), Actas del V Congreso de la Asociación Internacional Siglo de Oro. Münster, 1999, Madrid-Frankfurt am Main, IberoamericanaVervuet, pp. 604-613. Disponible en línea: https://cvc.cervantes.es/literatura/aiso/pdf/05/aiso_5_060.pdf.

GARCía Berrio, Antonio, Formación de la teoría literaria moderna, 1, La tópica horaciana en Europa, Murcia, CUPSA Editorial, 1977. , Formación de la teoría literaria moderna, 2, Teoría poética del Siglo de Oro, Murcia, Universidad de Murcia-Imprenta de la Universidad de Málaga, 1980. , Introducción a la poética clasicista. (Comentario a las Tablas Poéticas de Cascales), Madrid, Taurus, 1988.

GARCía GiBert, Javier, La humanitas hispana. Sobre el humanismo literario en los Siglos de Oro, Salamanca, Universidad de Salmanca, 2010.

GARCÍA RoMero, Fernando, "Una traducción inédita de Marcial”, MYRTIA. Revista de Filología Clásica de la Universidad de Murcia, año 2, vol. 2 (1987), pp. 43-58. Disponible en línea: http://interclassica.um.es/var/plain/storage/original/application/bebc25ed91d792a648abd43d827bad3 5.pdf. 
GARCía SANTO-TOMÁs, Enrique, "Introducción” para Lope de Vega, Arte nuevo de hacer comedias, E. García Santo-Tomas (ed.), Madrid, Cátedra, pp. 9-127.

García Soriano, Justo, "Don Luis Carrillo y Sotomayor y los orígenes del culteranismo”, Boletín de la Real Academia Española, 1926, pp. 591-629.

, El humanista Francisco Cascales. Su vida y sus obras. Estudio biográfico, bibliográfico y crítico, Madrid, Tip. de la “Revista de Arch., Bibl. y Mus.”, 1925.

García Yebra, Valentín, Poética de Aristóteles. Edición trilingüe, Madrid, Gredos, 2010.

GARIN, Eugenio, La cultura del Rinascimento, Milano, Il Saggiatore, 2012.

Gómez CAmacho, Alejandro y José Manuel Rico García, "La oda en preceptivas y tratados españoles”, en Begonia LÓPEZ BUENo (ed.), La oda. II Encuentro Internacional sobre Poesía del Siglo de Oro. (Sevilla-Córdoba. 16-21 de noviembre de 1992), Cádiz: Universidad de Sevilla-PASO-Universidad de Córdova, 1993, pp. 339-418.

Gracián y Morales, Baltasar, Obras de Lorenzo Gracian, divididas en dos tomos. I. El Criticón, tratando en la primera Parte de la Niñez, y juventud: en la segunda de la Varonil Edad, y en la tercera de la Vejez. El Discreto. El Politico Fernando el Catholico. El Heroe, Geronymo y Juanbaut. Verdussen, Amberes, 1669. Disponible en línea: https://ia902704.us.archive.org/28/items/obrasdelorenzog02moragoog/obrasdelorenzog02moragoog. pdf).

Obras de Lorenzo Gracian. Tomo segundo que contiente La agudeza, y arte de ingenio. El Discreto. El Politico Don Fernando el Catolico. Meditaciones varias para antes y despues de la Sagrada Comunion, que hasta aora ha corrido con titulo de Comulgador, Barcelona, Antonio Lacavalleria, 1669. Disponible en línea: https://ia801608.us.archive.org/5/items/A003084/A003084.pdf.

HARO, Marta, "Erotismo y arte amatoria en el discurso médico de la Historia de la donzella Teodor", Revista de Literatura Medieval, V (1993), pp. 113-125.

Herrera, Fernando de, Obras de Garci Lasso dela Vega con anotaciones de Fernando Herrera, al ilustrissimo i ecelentissimo Señor Don Antonio de Guzman, Marques de Ayamonte, Governador del Estado de Milan, i Capitan General de Italia, Sevilla, Alonso de la Barrera, 1580. Disponible en http://www.cervantesvirtual.com/obra-visor/obras-de-garcilasso-de-la-vega-0/html/ff83d41a-82b1-11df-acc7-002185ce6064_1.htm.

HERRERA ZAPIÉN, Tarsicio, "Introducción” para Quinto Horacio Flaco, Arte poética, Tarsicio Herrera Zapién (trad. y ed.), México, UNAM, 1970, pp. VII-CXIX.

Herrero García, Miguel, Estimaciones literarias del siglo XVII, Madrid, Voluntad, 1930. 
HIDALGO-SERNA, Emilio, “Origen y causas de la 'agudeza': necesaria revisión del 'conceptismo' español", en Sebastián Neumeister (ed.), Actas del IX Congreso de la Asociación Internacional de Hispanistas, I, Frankfurt am Main, Vervuert, pp. 477-489.

Horacio Flaco, Quinto, Arte poética, Tarsicio Herrera Zapién (trad. y ed.), México, UNAM, 1970. Huarte de SAn JuAn, Juan, Examen de ingenios para las ciencias, Guillermo Serés (ed.), Madrid, Cátedra, 1989.

ILlades AguiAR, Gustavo, "Observaciones sobre la actio del lector. (De La Celestina a la sátira anónima novohispana)", Escritos. Revista del Centro de Ciencias del Lenguaje, 26 (2002), pp. 13-35.

JÁuregui, Juan de, Discurso poético, Mercedes Blanco (ed.), 2016. Disponible en línea: https://obvil.sorbonne-universite.fr/corpus/gongora/1624_discurso-poetico\#body-1-1.

, Rimas de Don Ivan de Iavregvi, Sevilla, por Francisco de Lyra Varreto, 1618. Disponible en línea: https://play.google.com/books/reader?id=zvJFAAAAcAAJ\&hl=es_419\&pg=GBS.PP5.

KoHUT, Karl, Las teorías literarias en España y Portugal durante los siglos XV y XVI. Estado de la investigación y problemática, Madrid, C.S.I.C., 1973.

Kristeller, Paul Oskar, El pensamiento renacentista y sus fuentes, Michael Mooney (comp.), Federico Patán López (trad.), México. FCE, 1982.

LACADENA y CALERO, Esther, "El discurso oral en las academias del Siglo de Oro", Criticón, 41 (1988), pp. 87-102.

LAPESA Melgar, Rafael, Introducción a los estudios literarios, Madrid, Cátedra, 2008.

LAUSBERG, Heinrich Manual de retórica literaria. Fundamentos de una ciencia de la historia, 3 vols., José Pérez Riesco (trad.), Madrid, Gredos, 1966-1969.

LIDA DE MALKIEL, María Rosa, La idea de la fama en la Edad Media castellana, México, FCE, 2006.

LLUís CANET, Josep, "Estructura del saber y estructura del poder: organización y funciones de la Academia de los Nocturnos de Valencia", en Evangelina Rodríguez Cuadros, De las academias a la Enciclopedia: el discurso del saber en la modernidad, Valencia, Edicions Alfons el Magnànim, Institució Valenciana d’Estudis i Investigació, pp. 95-124.

LOPEZ, François, "Sobre la moderna filosofía poética de Alonso López Pinciano”, en Christophe Couderc y Benoit, «Por discreto y por amigo». Mélanges offerts à Jean Canavaggio, Madrid, Casa de Velázquez, 2005, pp. 579-602.

LÓPEZ BUENO, Begoña, “Las retóricas españolas en el siglo XVI: un canon al margen”, en Begoña López Bueno (ed.), El canon poético en el siglo XVI. VIII Encuentro Internacional sobre 
Poesía del Siglo de Oro, Sevilla, Grupo PASO, Universidad de Sevilla y Secretariado de Publicaciones, 2008, pp. 47-74.

, "Poesía, poética y retórica en el siglo de oro español: la teoría frente al Espejo”, en Natalia Fernández Rodríguez y María Fernández Ferreiro (coords.), Literatura Medieval y Renacentista en España: líneas y pautas, Salamanca, Universidad de Salamanca y Sociedad de Estudios Medievales y Renacentistas (SEMYR), 2012, pp. 97-117.

LuZÁn, Ignacio de, La poetica, ó reglas de la poesia en general, y de svs principales especies, Zaragoza, por Francisco Revilla, 1737. Disponible en línea: https://books.google.com.mx/books?id=hTvmhkwZGKgC\&printsec=frontcover\&dq=luzan+poetica $\& h l=e s \& s a=X \& v e d=0 a h U K E w i h r o i X 1 O v g A h V C e K w K H X K 2 A P k Q 6 A E I K D A A \# v=o n e p a g e \& q=1$ uzan\%20poetica\&f=false.

MAUREL-INDART, Hélene, Sobre el plagio, Buenos Aires, FCE, 2014.

MARCIAL, Marco Valerio, Epigramas, I (Libros 1-7), Enrique Montero Cartelle (trad.), Madrid, Consejo Superior de Investigaciones Científicas, 2004.

Matas Caballero, Juan, Juan de Jáuregui. Poesía y poética, Sevilla, Diputación Providencial de Sevilla, 1990.

MenÉndez Pelayo, Marcelino, Historia de las ideas estéticas en España, II, Siglos XVI Y XVII, Buenos Aires, Espasa-Calpe, 1943.

Horacio en España, I, Madrid, A. Pérez Dubrull, 1885.

MuÑoz PeÑA, Pedro, "Introducción” para Alonso López Pinciano, Filosofía antigua poética, P. Muñoz Peña (ed.), Valladolid, Imprenta y Librería Nacional y Extranjera de Hijos de Rodríguez, Libreros de la Universidad y del Instituto, 1894, pp. V-XXXIV. Disponible en línea: https://archive.org/details/filosofiaantiqua00lpez.

NAVARRO, Rosa, "Introducción biográfica y crítica" y "Nota previa" para Luis Carrillo y Sotomayor, Obras, Rosa Navarro (ed.), Madrid, Castalia, 1990, pp. 9-97.

NEWELS, Margarete Los géneros dramáticos en las poéticas del Siglo de Oro. Investigación preliminar al estudio de la teoría dramática en el Siglo de Oro, Amadeo Sole-Leris (trad.), London, Tameis Books Limited, 1974.

ONG, Walter J, Oralidad y escritura: tecnologías de la palabra, Angélica Scherp (trad.), México, FCE, 2016.

OrTIZ CANSECo, Martha, s. v. "Carrillo y Sotomayor, Luis", en Pablo Jauralde Pou (dir.), Diccionario filológico de literatura española (Siglo XVII), I, Gavela, Delia y Pedro C. Rojo Alique (coords.), Nueva Biblioteca de la Erudición y Crítica, Edhasa-Castalia, edición digital, 2012, pp. 278-283. Consultado en línea: http://bidi.uam.mx:6449/visor/31011. 
PARAíso, Isabel, “Fundación del canon métrico: el Arte Poética Española, de Juan Díaz Rengifo”, en Isabel Paraíso (coord.), Retóricas y poéticas españolas (siglos XVI-XIX): L. de Granada, Rengifo, Artiga, Hermosilla, R. de Miguel, Milá y Fontanals, Valladolid, Secretariado de publicaciones e intercambio editorial, Universidad de Valladolid, 2000, pp. 47-93.

PASTOR, José Francisco, "Introducción” a Las apologías de la lengua castellana en el siglo de oro, J. F. Pastor (ed.), Madrid, Compañía Ibero-Americana de Publicaciones, 1929, pp. XII-XXX. Peregrini, Matteo, Delle acutezze, Erminia Ardissino (ed.), Torino, Edizioni Res, 1997.

Porqueras MAyo, Alberto, Estudios sobre Cervantes y la Edad de Oro, Alcalá de Henares, Centro de Estudios Cervantinos, 2003.

, "Función del 'vulgo' en la preceptiva dramática de la Edad de Oro", en Federico Sánchez Escribano y Alberto Porqueras Mayo, Preceptiva dramática española del Renacimiento y el Barroco, Madrid, Gredos, 1972, pp. 365-387.

, "Introducción" para Luis Alfonso de Carvallo, Cisne de Apolo, A.

Porqueras Mayo (ed.), Reichenberger, Kassel, 1997, pp. 1-32.

, Temas y formas de la literatura española, Madrid, Gredos, 1972.

Quintiliano, Marco Fabio, Instituciones oratorias, 2 vols., Ignacio Rodríguez y Pedro Sandier (trads.), Madrid, Librería de la Viuda de Hernando y Cia., 1887. Disponible en línea: http://www.cervantesvirtual.com/obra/instituciones-oratorias--0/.

RANDElli Romano, Fiorenza, "Introduzione” para Luis Carrillo y Sotomayor, Poesie. I. Sonetti, F. Randelli Romano (ed. y trad.), Firenze, Casa Editrice D’Anna y Università degli Studi di Firenze, 1971, pp. 9-95.

RICO, Francisco, El sueño del humanismo. (De Petrarca a Erasmo), Madrid, Alianza, 1997. [1993]

RICO GARCíA, José Manuel, “'Sin poetas hay poéticas’: los tratados de preceptiva literaria y el canon en el siglo XVII", en Begoña López Bueno (coord.), El canon poético en el siglo XVII. IX Encuentro internacional sobre poesía del Siglo de Oro, Sevilla, Grupo Paso y Universidad de Sevilla, 2010, pp. 93-123.

Rico Verdú, José, “Introducción” para Alonso López Pinciano, Philosophia antigua poética, José Rico Verdú (ed.), Madrid, Fundación José Antonio de Castro, 1998, pp. V-XX.

Rioseco, Marcelo, “Jáuregui y la censura a la poesía nueva”, en Espéculo. Revista de estudios literarios. Universidad Complutense de Madrid, 34 (2006). Disponible en línea: https://webs.ucm.es/info/especulo/numero34/jauregui.html.

RODRÍGUEZ BELTRÁN, Joaquín, Las fuentes antiguas de la agudeza del ingenio en la retórica renacentista, tesis doctoral, México, UNAM, 2017. 
Romanos, Melchora "Don Juan de Jáuregui: vida y obras”, en J. de Jáuregui, Discurso poético. Advierte el desorden y engaño de algunos escritos, M. Romanos (ed.), Madrid, Editora Nacional, 1978, pp. 9-53.

SÁnCHEZ DE BADAJOZ, Garci, Cancionero de Garci Sánchez De Badajoz, Julia Castillo (ed.), Madrid, Editora Nacional, 1980.

SÁnCHEZ, José, Academias literarios del Siglo de Oro, Madrid, Gredos, 1961.

SÁnchez Escribano, Federico y Alberto Porqueras Mayo (eds.), Preceptiva dramática española. Del Renacimiento y el Barroco., Madrid, Gredos, 1972.

SERÉS, Guillermo, "Introducción” para Juan Huarte de San Juan, Examen de ingenios para las ciencias, Madrid, Cátedra, 1989, pp. 11-131.

SHEPARD, Sanford, El Pinciano y las teorías literarias del Siglo de Oro, Madrid, Gredos, 1970. , 'Las huellas de Escalígero en la 'Philosophia antigua poética' de Alonso López Pinciano", Revista de Filología Española, vol. XLV, n. 1/4 (1962), pp. 311-317. Disponible en línea: http://revistadefilologiaespañola.revistas.csic.es.

TESAURO, Emanuele, Il cannocchiale aristotelico o sia Idea dell'argvta et ingeniosa elcvtione che serue à tutta l'Arte oratoria, lapidaria, et simbolica esamitata co' Pirncipij del divino Aristotele, Torino, Bartolomeo Zauatta, 1670. Disponible en línea: https://archive.org/details/ilcannocchialear00tesa.

Thomas, Lucien-Paul, Góngora et le gongorisme considerés dans leurs rapports avec le marinisme, Paris, Champion, 1909.

URRíEZ y AZARA, José Jordán de, Biografia y estudio crítico de Jáuregui, Madrid, Est. Tipográfico 'Sucesores de Rivadeneyra', 1899.

Vega CARPIO, Lope de, Rimas de Lope de Vega Carpio. Aora de nvevo Imprimidas con el nvevo arte de hazer Comedias deste tiempo, Milan, Ieronimo Bordon Librero, 1611. Disponible en línea: http://bdh.bne.es/bnesearch/CompleteSearch.do?languageView=es\&field=todos\&text=rimas +lope \&show YearItems $=\&$ exact $=$ on $\&$ textH=\&advanced $=$ false $\&$ completeText=\&pageSize $=$ 1\&pageSizeAbrv=30\&pageNumber=2.

VILANOVA, Antonio, "Preceptistas españoles de los siglos XVI y XVII”, en Guillermo Díaz-Plaja (dir.), Historia general de las literaturas hispánicas, III, Renacimiento y Barroco, Barcelona, Vergara, 1968, pp. 565-726.

ZEPEDA, Jorge, “Clasicismo, estética, tradición: el Orfeo de Juan de Jáuregui”, NRFH, LXVI, no. 2 (2016), p. 527-542.

Zumthor, Paul, La letra y la voz de la 'literatura' medieval, Julián Presa (trad.), Madrid, Cátedra, 1989. 


\section{Catálogos en línea}

Biblioteca Digital Hispánica:

http://www.bne.es/es/Catalogos/BibliotecaDigitalHispanica/Inicio/index.html

Biblioteca Virtual Asutrias:

https://bibliotecavirtual.asturias.es/i18n/estaticos/contenido.cmd?pagina=estaticos/presentacion

Universidad Complutense de Madrid:

https://biblioteca.ucm.es 
"AgudEZA" E "INGENIO" EN CINCO POÉTICAS ESPAÑOLAS DE LA SEGUNDA MITAD DEL SIGLO XVI Y PRINCIPIOS DEL XVII.
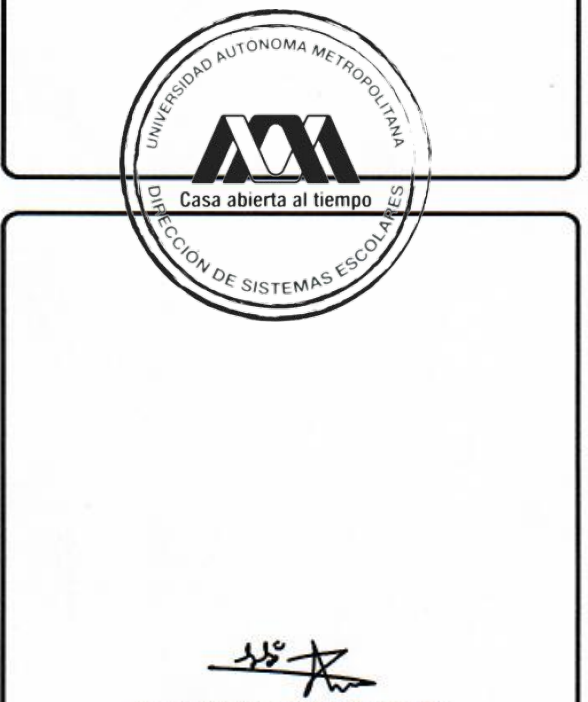

SHARON SUAREZ LARIOS ALUMNA

REVISÓ

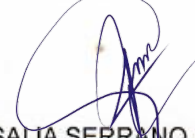

MTRA. ROSALIA SERRANO DE LA PAZ DIRECTORA DE SISTEMAJS ESCOLARES
Con base en la Legislación de la Universidad Autónoma Metropolitana, en la Ciudad de México se presentaron a las 12:00 horas del día 24 del mes de noviembre del año 2020 POR VÍA REMOTA ELECTRÓNICA, los suscritos miembros del jurado designado por la Comisión del posgrado:

DRA. LILLIAN VON DER WALDE MOHENO

DR. MARX ARRIAGA NAVARRO

DR. GUSTAVO ILLADES AGUIAR

Bajo la Presidencia de la primera y con carácter de Secretario el último, se reunieron para proceder al Examen de Grado cuya denominación aparece al margen, para la obtención del grado de:

MAESTRA EN HUMANIDADES (LITERATURA)

DE: SHARON SUAREZ LARIOS

$y$ de acuerdo con el artículo 78 fracción III del Reglamento de Estudios Superiores de la Universidad Autónoma Metropolitana, los miembros del jurado resolvieron:

\section{APROBAR}

Acto continuo, la presidenta del jurado comunicó a la interesada el resultado de la evaluación y, en caso aprobatorio, le fue tomada la protesta.
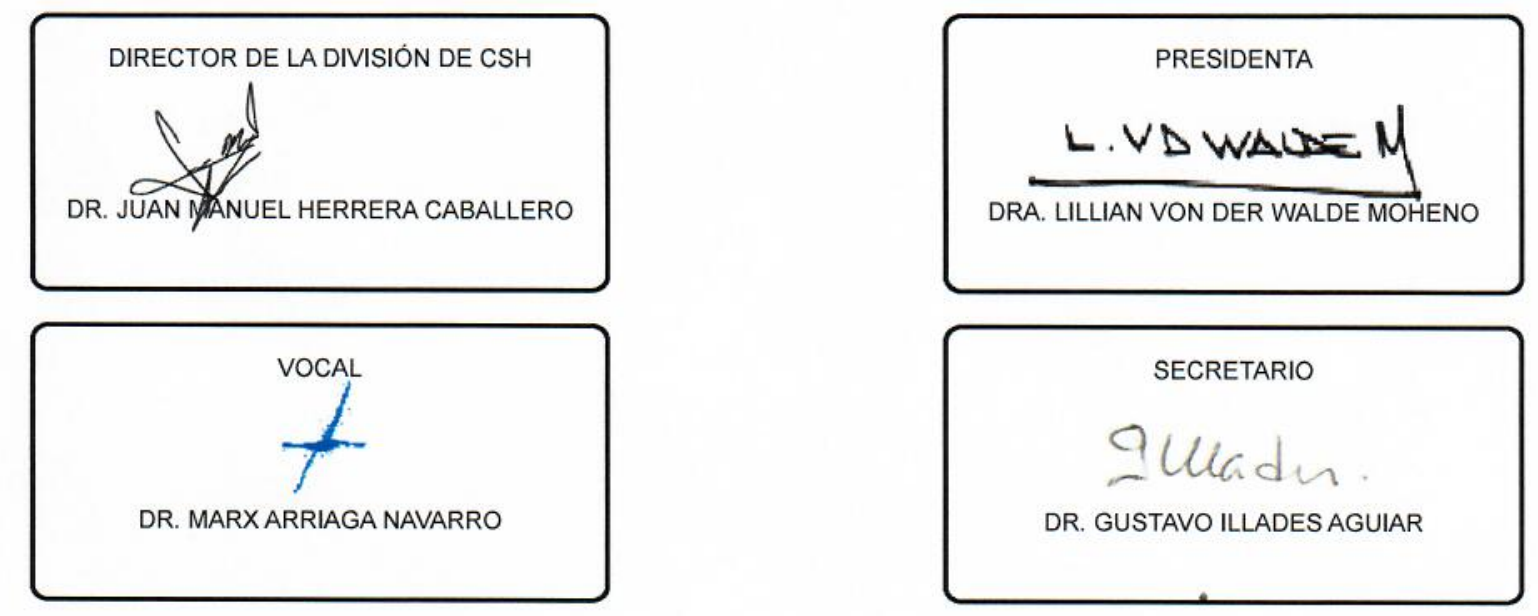